A REGRA DO PREJUÍZO E AS NULIDADES PROCESSUAIS: CONSTRUÇÃO DE UM MODELO RACIONAL DE APLICAÇÃO DO 'PAS DE NULLITÉ SANS GRIEF' NO ÂMBITO DO PROCESSO PENAL BRASILEIRO

Dissertação de Mestrado

Orientador: Professor Associado Dr. Gustavo Henrique Righi Ivahy Badaró

UNIVERSIDADE DE SÃO PAULO

FACULDADE DE DIREITO

SÃO PAULO-SP

2015 
DANIEL ZACLIS

\title{
A REGRA DO PREJUÍZO E AS NULIDADES PROCESSUAIS: CONSTRUÇÃO DE UM MODELO RACIONAL DE APLICAÇÃO DO 'PAS DE NULLITÉ SANS GRIEF' NO ÂMBITO DO PROCESSO PENAL BRASILEIRO
}

\begin{abstract}
Dissertação de Mestrado apresentada à Banca Examinadora do Programa de Pós-Graduação em Direito, da Faculdade de Direito da Universidade de São Paulo, como exigência parcial para obtenção do título de Mestre em Direito, na área de concentração Direito Processual, sob a orientação do Professor Associado Dr. Gustavo Henrique Righi Ivahy Badaró.
\end{abstract}

\author{
UNIVERSIDADE DE SÃO PAULO \\ FACULDADE DE DIREITO \\ SÃO PAULO-SP \\ 2015
}


Autorizo a reprodução e divulgação total ou parcial deste trabalho, por qualquer meio convencional ou eletrônico, para fins de estudo e pesquisa, desde que citada a fonte.

Ficha Catalográfica

\section{Zaclis, Daniel}

Z12r A regra do prejuízo e as nulidades processuais: construção de um modelo racional de aplicação do 'pas de nullité sans grief' no âmbito do processo penal brasileiro / Daniel Zaclis. -- São Paulo: USP / Faculdade de Direito, 2015. $199 \mathrm{f}$.

Orientador: Prof. Associado Gustavo Henrique Righi Ivahy Badaró Dissertação (Mestrado), Universidade de São Paulo, USP, Programa de Pós-Graduação em Direito, Direito Processual, 2015.

1. Processo penal. 2. Nulidade processual penal. 3. Ato processual. 4. Regra do prejuízo. I. Badaró, Gustavo Henrique Righi Ivahy. II. Título. 


\section{AGRADECIMENTOS}

Tarefa das mais ingratas é agradecer a algumas poucas pessoas pela contribuição no desenvolvimento desse trabalho. Foram tantos aqueles que, à sua maneira, me garantiram a energia e a motivação necessárias para o cumprimento deste desiderato, que as poucas linhas de que disponho aqui certamente me forçarão a deixar de fora nomes que obrigatoriamente deveriam ser lembrados. A estas pessoas, peço minhas adiantadas desculpas, na esperança de que a vida me conferirá a oportunidade de agradecer-lhes pessoalmente.

Inicialmente, agradeço aos meus pais - Roberto e Rosa. As palavras serão sempre insuficientes para representar minha gratidão pelo amor incondicional externado por vocês em todas as etapas de minha vida. O presente trabalho é, em grande medida, fruto dos valores e da educação que me foram passados. De forma específica, agradeço ao meu pai pelas incansáveis leituras que fez do texto, sempre com um olhar clínico para detectar impropriedades e sugerir melhorias.

Ao meu querido irmão, Flavio, agradeço pelo irrestrito companheirismo. Sou extremamente grato por poder contar com você nas mais variadas situações.

São muitos os motivos pelos quais preciso agradecer ao Professor Gustavo Henrique Righi Ivahy Badaró, orientador deste trabalho. É raro ver uma pessoa com tamanho tino para a vida acadêmica e, ao mesmo tempo, detentora de uma humildade característica dos grandes homens. Serei eternamente grato por ter confiado em minha capacidade para desenvolver a presente dissertação e pelas inesquecíveis lições que recebi no decorrer desses últimos anos. O senhor, Professor, é um exemplo de ser humano.

Ainda no plano acadêmico, agradeço aos Professores José Raul Gavião de Almeida e Marta Cury Saad Gimenes pela atenta leitura de meu trabalho e as inestimáveis considerações feitas à época do Exame de Qualificação.

O curso de pós-graduação, para além de me conceder uma oportunidade ímpar de aprofundamento na matéria do processo penal, me aproximou de pessoas fantásticas, as quais, de certa forma, tornaram muito mais prazeroso o caminho para conclusão deste trabalho. Registro, então, meus agradecimentos aos amigos Anderson Bezerra Lopes, Andrey Borges de Mendonça, Antonio Tovo, Conrado Gontijo, Fernanda Vilares, Jorge Paschoal, Marcio Britto Arantes Filho, Nathalia Rocha, Renato Stanziola Vieira e Ricardo Sidi. 
Agradeço a todos do CAZ Advogados por compreenderem a minha ausência temporária em determinados momentos. Em especial, agradeço às minhas queridas sócias, Helena Regina Lobo da Costa e Marina Pinhão Coelho Araújo, por estarem ao meu lado nas batalhas diárias da advocacia e por continuamente me incentivarem a seguir meus sonhos. Não poderia deixar, também, de agradecer ao Andre Ricardo Godoy, pelo valioso auxílio na dissertação e, sobretudo, pelo imprescindível acompanhamento das demandas do dia a dia enquanto precisei me ausentar.

À Roberta Scocuglia Rodrigues Azenha, amor da minha vida, serão sempre infinitos os agradecimentos, já que eles se avolumam a cada dia. O tempo somente aumenta a admiração que tenho por você. As minhas angústias durante esse período seriam insuperáveis sem o seu sorriso sensível e sua incrível capacidade de me fazer feliz. Obrigado por tudo e muito mais, "mor"!

Ao Eduardo, meu filho querido, agradeço pela motivação diária de escrever o presente trabalho. Os poucos dias de sua existência já foram suficientes para provar que a vida não tinha muito sentido antes de você estar entre nós. 
ZACLIS, Daniel. A regra do prejuízo e as nulidades processuais: construção de um modelo racional de aplicação do 'pas de nullité sans grief' no âmbito do processo penal brasileiro. 2015. 199 f. Dissertação (Mestrado) - Faculdade de Direto, Universidade de São Paulo, São Paulo, 2015.

\section{RESUMO}

O presente trabalho tem como escopo central a análise da regra do prejuízo relacionada às nulidades no processo penal. Corolário da teoria da instrumentalidade das formas, a regra do prejuízo dispõe que somente será reconhecida a nulidade se do ato viciado resultar algum prejuízo para a acusação ou para a defesa. A despeito de sua importância para a construção de um modelo finalístico, referida categoria do prejuízo vem sendo aplicada de forma caótica pela jurisprudência pátria. Na realidade, o entendimento daquilo que de fato configura o "prejuízo" para efeitos do artigo 563 do Código de Processo Penal se perdeu em meio a decisões controversas e confusas acerca do tema. A regra, inicialmente adotada no processo civil, foi transportada ao processo penal sem as devidas cautelas e desprovida dos necessários ajustes. Inexiste uma sistematização mínima para aferição do prejuízo, sendo certo que hodiernamente se confere uma discricionariedade absoluta ao magistrado para determinar se no caso concreto há alguma lesão às partes. Nesse cenário, a precípua função da forma, que é assegurar uma proteção ao acusado contra eventuais arbitrariedades do Estado, muitas vezes é deixada de lado. Toda essa problemática tem gerado um ambiente instável para correta aplicação das nulidades, o que acaba por acarretar uma notável insegurança jurídica. O presente estudo tem a pretensão de propor um modelo racional de aferição do prejuízo, com base no qual o magistrado encontrará critérios mais claros para a aplicação das nulidades no processo penal.

Palavras-chave: Processo penal - Forma do ato processual - Nulidades processuais-penais - Regra do prejuízo. 
ZACLIS, Daniel. The harmless error rule and procedural nullities: the elaboration of a rational model to apply 'pas de nullité sans grief' in criminal procedures. 2015. 199 p. Degree (Master) - Faculty of Law, University of São Paulo, São Paulo, 2015.

\begin{abstract}
This research aims to analyze the harmless error rule, strictly related to the subject of nullities in the criminal procedure. As a deployment of the theory of instrumentality of the procedural forms, the harmless error rule provides that a mistake will only cause the nullity of the procedure if there is evidence to support that the prosecution or the defense were actually harmed by that error. Although extremely important for the incorporation of teleological model of nullity, the mentioned harmless error rule has been wrongfully applied by Brazilian courts. In reality, the understanding of the actual meaning of the word "harm", as per article 563 of the Criminal Procedure, has been lost throughout so many different confusing and controversial court decisions. The harmless error rule, initially used in civil cases, was brought to criminal procedure without the needed adjustments. There is no minimum systematization in order to identify a harmful error and, therefore, nowadays the judge has total discretion to determine in each case the severity of the error. Given this reality, the most important function of a procedural form, which is to protect the defendant against eventual arbitrary measures committed by the State, is normally forgotten. All these issues have caused an unstable background regarding the correct application of the nullities, leading to a noticeable legal uncertainty in this subject. This research has the intention to come up with a rational model of application of the harmless error rule, based on which the judges will find the necessary criteria to recognize nullities in criminal procedures.
\end{abstract}

Key words: Criminal procedure - Procedural forms - Nullity of criminal procedure Harmless Error Rule. 


\section{SUMÁRIO}

\section{A FUNÇÃo dO PROCESSO PENAL MODERNO: NOÇÃO DO PROCESSO COMO INSTRUMENTO A SERVIÇO DA PROTEÇÃO DOS DIREITOS FUNDAMENTAIS.}

1.1. A evolução do processo penal: a atual compreensão de seu caráter instrumental .............13

1.2. Teoria Geral do Processo e a inadequação de uma instrumentalidade universal ................16

1.3. A instrumentalidade inquisitória: em busca da superação de dogmas inexequíveis .........25

1.3.1. A problemática inerente à concepção da verdade real no estudo do processo ........25

1.3.2. O bem-estar comum e as finalidades coletivas como critérios orientadores do

Processo Penal. .33

1.4. A instrumentalidade constitucional do processo: identificação da forma como guardiã das garantias individuais.

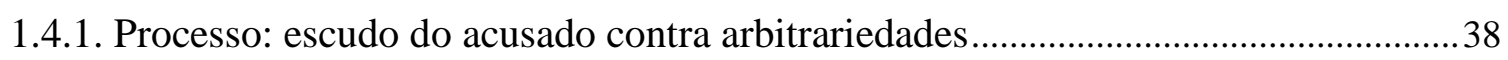

1.4.2. A forma como guardiã das garantias fundamentais .................................................4

2. O ATO PROCESSUAL PENAL IMPERFEITO: TRATAMENTO ATUAL DA MATÉRIA E A RETÓRICA DISTORCIDA DA INSTRUMENTALIDADE DAS FORMAS

2.1. Ato Processual.

2.1.1. Definição do ato processual: a necessária diferenciação em relação a outros atos jurídicos.

2.1.2. Das dimensões do ato à fattispecie processual: a fisiologia do ato processual válido.

2.2. A classificação das respostas jurídicas à atipicidade processual

2.2.1. Atos irregulares

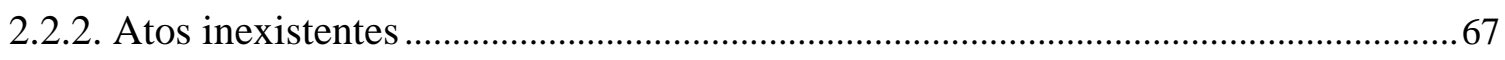

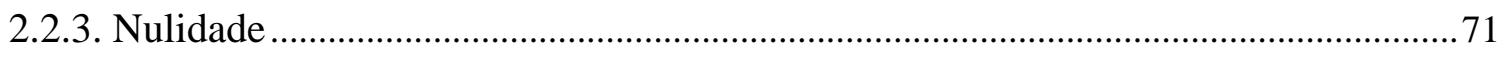

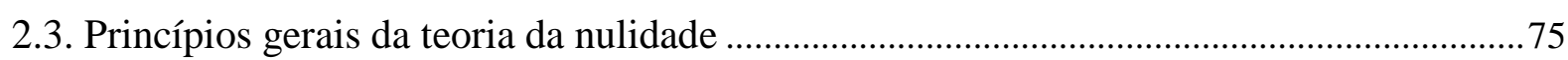

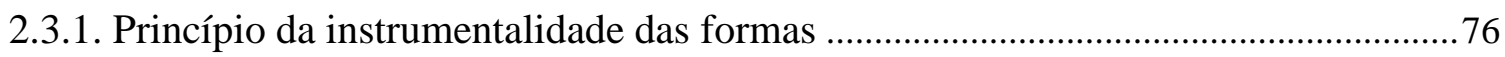

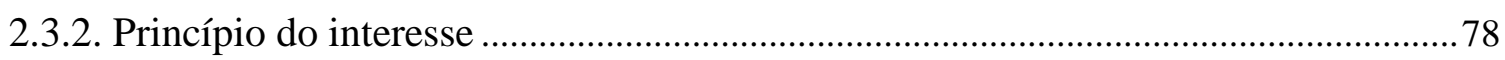

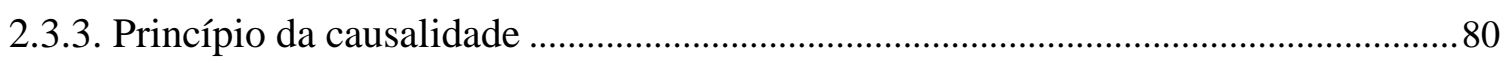

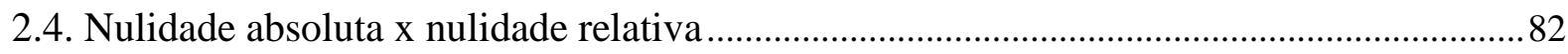

2.4.1. Diferenciação inexistente: a insuficiência de critérios objetivos para classificação das nulidades

2.5. Nulidade e desentranhamento: uma aproximação necessária entre as sanções à prova ilegal e as sanções à prova ilegítima . 
2.6. O discurso da instrumentalidade e relativização das formas em nome da economia processual: a liberdade disfarçada das formas....

\section{A REGRA DO PREJUÍZO APLICADA ÀS NULIDADES NO PROCESSO} PENAL - ASPECTOS DOGMÁTICOS E A CONFUSA JURISPRUDÊNCIA SOBRE O ASSUNTO

3.1. Origem do pas de nullité sans grief e seu desenvolvimento histórico no Brasil. .98

3.2. Instrumentalidade das formas e a regra do pas de nullité sans grief: necessária dissociação das ideias e a inexistência de um princípio-mestre em matéria de nulidades

3.3. A natureza jurídica do "prejuízo" nas nulidades processuais penais

3.4. O papel do pas de nullité sans grief na separação entre nulidade absoluta e relativa: o equívoco de se presumir o que a lei não permite

3.5. A problemática jurisprudência pátria acerca do pas de nullité sans grief.

3.5.1. Nulidade em razão da ausência do acusado em audiência

3.5.2. Nulidade da decisão de recebimento da denúncia por carência de motivação .

3.5.3. Nulidade em função de incompetência de juízo

3.5.4. Ausência de alegações finais (memoriais) defensivas ao final da instrução preliminar nos processos de competência do Tribunal do Júri.

\section{A DEFINIÇÃO DO PREJUÍZO- UMA PROPOSTA DE RACIONALIZAÇÃO DO} PROCESSO DECISÓRIO PARA IDENTIFICAÇÃO DAS NULIDADES.

4.1. Reflexões iniciais: a complexa sistematização de temas ligados ao vício processual e a equivocidade de focar o estudo na casuística

4.2. Para se construir um sistema de nulidades, é indispensável o prejuízo?

4.3. A desvinculação do prejuízo da ideia de "verdade substancial" ou "decisão da causa": a superação do subjetivismo inquisitório do artigo 566, do CPP

4.4. Da necessidade de análise independente do prejuízo em relação às classificações das nulidades

4.5. Diretrizes cumulativas para uma decisão racional sobre o prejuízo nas nulidades.

4.5.1. A presunção de lesão às partes pela inobservância do ordenamento processual

- a retomada do caráter garantístico da forma

4.5.2. Ônus argumentativo para afastamento da presunção de lesão

4.5.2. A "perda de uma oportunidade processual” como critério indicador de lesão.

4.5.3. O erro proposital da parte como condição de inexistência do prejuízo.

4.5.4. O prejuízo específico do Ministério Público 


\section{INTRODUÇÃO}

O tratamento conferido às nulidades, no âmbito do processo penal pátrio, precisa ser revisto. Já há muito as bases sobre as quais se ancora o instituto da nulidade revelam-se inadequadas em vista da atual conjuntura jurídico-penal, sobretudo porque, próprias para um modelo (neo)inquisitório do Código de Processo Penal vigente, não se sustentam mais em meio a um sistema processual constitucional pós 88 .

Alcunhado por alguns de viga mestre ${ }^{1}$ do sistema de nulidades, o princípio do prejuízo (instrumentalidade das formas), ${ }^{2}$ segundo o qual somente anular-se-á um ato se dele decorrer um prejuízo às partes, da forma como vem sendo aplicado hodiernamente, constitui um dos entraves ao desenvolvimento de uma teoria das nulidades mais adequada ao programa normativo constitucional em matéria de processo penal. Deveras, com o passar dos anos, o aludido princípio, além de ter sido desvirtuado de seu sentido original, vem servindo de fundamento, amiúde, para que se legitime equivocadamente o desrespeito às normas procedimentais.

Não se há de negar - e desde logo cumpre consignar - que a forma processual possui uma finalidade, não sendo ela um fim em si mesma. O ritualismo, consubstanciado por um amor desmedido à forma, não encontra mais espaço em uma visão moderna do processo penal, o qual, ao contrário, deve ser concebido a partir de seu aspecto instrumental.

Essa característica do processo (e da própria forma do ato processual), no entanto, não pode servir de carta branca para que as mais diversas deformidades processuais sejam flexibilizadas no decorrer da persecução penal. ${ }^{3}$ Sob o manto da instrumentalidade das formas, atualmente há uma generalizada mitigação dos vícios processuais, sempre fundada

\footnotetext{
${ }^{1}$ GRINOVER, Ada Pellegrini; FERNANDES, Antonio Scarance; GOMES FILHO, Antonio Magalhães. As nulidades no processo penal. 12. ed. São Paulo: Ed. Revista dos Tribunais, 2011. p. 27. A expressão também é encontrada na obra de Fernando da Costa Tourinho Filho (Processo penal. São Paulo: Saraiva, 2009. v. 3, p. 119).

${ }^{2}$ No decorrer do trabalho, a denominação "princípio" utilizada frequentemente pela doutrina para caracterizar o pas de nullité sans grief será objeto de exame minucioso. Será questionada, inclusive, a razão de a doutrina tratar o prejuízo e a instrumentalidade como se fossem sinônimos.

${ }^{3}$ Não por outra razão, José Frederico Marques já alertava que "saber situar a questão das nulidades num justo termo em que a relevância das formas processuais seja temperada pela instrumentalidade do ato processual - eis a solução acertada para tão grave problema." (Elementos de direito processual penal. Atualizadores: Eduardo Reale Ferrari e Guilherme Madeira Rezem. 3. ed. Campinas: Millenium, 2009. v. 2, p. 399).
} 
na ideia de que o ato, mesmo praticado em desconformidade com a lei, atingiu a sua finalidade, não evidenciando prejuízo a qualquer das partes.

À vista dessa equação, que assumiu ares similares a dogmas no processo penal, cabem as seguintes indagações: A que $(\mathrm{m})$ serve a forma no processo penal? O que se entende por prejuízo para fins de reconhecimento de uma nulidade? A quem cabe o ônus de demonstrar o prejuízo gerado pelo ato imperfeito? Essas questões, e outras tantas, cercam diariamente a teoria das nulidades, e dificilmente são enfrentadas pela doutrina nacional, tampouco pela jurisprudência.

O presente trabalho, destarte, tem como escopo central o estudo da regra do prejuízo e seus efeitos atuais para o desenvolvimento de uma correta compreensão do tema das nulidades. A título de metodologia, parte-se do pressuposto de que o adágio pas de nullité sans grief está sendo mal aplicado no processo penal, passando-se, então, a investigar as razões que poderiam explicar os motivos para essa equivocada utilização dessa categoria.

Importante ressaltar que não se pretende, no decorrer do presente trabalho, desenvolver uma nova teoria das nulidades voltada ao processo penal. Uma rediscussão completa sobre as regras atinentes ao estudo das nulidades ampliaria em demasia o objeto do trabalho, o qual deve estar limitado ao aprofundamento da concepção de prejuízo vinculada às nulidades. ${ }^{4}$

Para cumprir tal desiderato, será imprescindível principiar pela análise da instrumentalidade do processo penal contemporâneo. Com efeito, somente se poderá entender o papel do ato processual, seus vícios, e as eventuais hipóteses de saneamento, se houver a identificação da genuína função do próprio processo penal. Nesse sentido, procurar-se-á abordar os diversos posicionamentos acerca do papel do processo, afastandose ideias aptas, em tese, a desvirtuar o sentido teleológico da atividade persecutória. Ao final do capítulo, enfim, será possível estabelecer o real sentido da manutenção das formas no processo penal.

Delineados os contornos da instrumentalidade do processo penal, o capítulo II será dedicado à análise do tratamento atual do ato imperfeito. Far-se-á, nesse sentido, o estudo das respostas jurídicas que hodiernamente vêm sendo dadas em face dos mais variados

\footnotetext{
${ }^{4}$ Para um estudo completo e inovador sobre teoria das nulidades no âmbito do processo penal, cf. GLOECKNER, Ricardo Jacobsen. Nulidades no processo penal: introdução principiológica à teoria do ato processual irregular. Salvador: Jus Podium, 2013.
} 
vícios processuais, demonstrando o descabimento de algumas concepções que atravessam décadas sem receberem a merecida atenção. O retrato de uma teoria engessada das nulidades é o que se procurará demonstrar, concluindo pela impossibilidade de mantê-la intocada diante da realidade processual atual.

A partir do terceiro capítulo, o trabalho passará a dar enfoque específico à regra do prejuízo relacionada às nulidades. Iniciando-se pela análise da origem da ideia de instrumentalidade das formas, bem como seus aspectos tradicionalmente civilísticos, o estudo examinará o posicionamento doutrinário acerca do assunto, inclusive para esclarecer alguns equívocos, repetidos ao longo dos anos, de forma irrefletida, os quais têm gerado verdadeiras barreiras para o devido desenvolvimento da matéria. De igual forma, realizar-se-á a análise jurisprudencial de determinadas hipóteses específicas, verificadas amiúde no decorrer da persecução penal, em que a regra do prejuízo tem sido submetida ao crivo do judiciário. O estudo desse cenário, doutrinário e jurisprudencial, enfim, possibilitará a detecção de pontos nevrálgicos no sistema, auxiliando de certa forma na eventual elaboração de medidas propositivas. ${ }^{5}$

Por derradeiro, o último capítulo se concentrará na construção de um modelo racional de decisão para aferição do prejuízo. Levando-se em conta a instrumentalidade do processo traçada no início do trabalho, somada ao estudo do incorreto tratamento atual da matéria de nulidades, será proposta outra visão possível para aplicação do pas de nullité sans grief. Para consecução desse intento, consignar-se-ão algumas premissas que devem necessariamente ser observadas no momento em que suscitado um vício no processo, de modo a orientar o magistrado na correta interpretação da regra do prejuízo. Espera-se, com essa pretendida racionalidade decisória, eliminar a insegurança jurídica que se revela patente no tema das nulidades processuais.

É por esse complexo e sinuoso caminho que pretende percorrer o presente trabalho. Adiante-se, desde já, que o estudo terá como anseio precípuo encontrar respostas relativas ao tema proposto, que sejam consentâneas com um modelo acusatório de processo penal, visto ser esse o principal sistema de um país que cada vez mais aspira por instituições democráticas sólidas, deixando de lado categorias, nada saudosas, típicas de modelos

\footnotetext{
${ }^{5}$ Até porque, nas palavras de Alberto Binder, que servem perfeitamente para o atual cenário das nulidades em nosso país, "esta teoría unitaria ha terminado por ser confusa, carente de un verdadero método de análisis que sirva de guía al intérprete. También ha influido en la debilidad teórica de esta visión unitaria una asimilación demasiado rápida de los problemas generales de las formas jurídicas a las formas procesales." (El incumplimiento de las formas procesales. Buenos Aires: Ad-Hoc, 2009. p. 17).
} 
inquisitivos. Considerando que o esgotamento do tema se afigura impossível, apenas uma nova leitura do prejuízo, calcada nos direitos e garantias constitucionais, ${ }^{6}$ é que se espera das páginas que se seguem.

${ }^{6}$ Conforme advertia Borges da Rosa, "pode-se, sem receio de erro, afirmar que os sistemas de apreciação das nulidades no Processo são tanto mais complicadas, extensos, e insidiosos quanto pior e mais insuficiente são garantidos os direitos individuas." (Comentários ao Código de Processo Penal. 3. ed. atualizada por Angelito Aiquel. São Paulo: Ed. Revista dos Tribunais, 1982. p. 639). 


\section{CAPÍTULO I. A FUNÇÃo DO PROCESSO PENAL MODERNO: NOÇÃO DO PROCESSO COMO INSTRUMENTO A SERVIÇO DA PROTEÇÃO DOS DIREITOS FUNDAMENTAIS}

O presente capítulo tem por escopo precípuo identificar a real função do processo penal moderno. Antes mesmo de entrar propriamente no tema das nulidades - que será explorado nos capítulos seguintes -, torna-se imprescindível definir as bases que legitimam a existência de um processo que pretenda ser consentâneo com o ordenamento constitucional vigente.

De se lembrar que o princípio da instrumentalidade das formas - um dos focos de estudo desse trabalho - rege que as normas processuais possuem uma finalidade - um sentido teleológico -, sendo certo que, mesmo diante da desobediência às formalidades estabelecidas pelo legislador, somente será reconhecida a invalidade do ato quando referida finalidade for comprometida pelo vício. ${ }^{7}$

Impossível, portanto, mergulhar a fundo no mencionado princípio e compreender o grau de instrumentalidade das formas sem antes proceder a um diagnóstico preciso sobre o papel desempenhado pelo próprio processo penal. Somente a partir do momento em que se delineia o que, ou a quem, o processo penal (todo) protege, é que se poderá detectar a medida de instrumentalidade de determinado ato viciado (parte). ${ }^{8}$

Para atingir o ponto de chegada almejado nesse capítulo específico, será necessário abordar determinadas teorias que de forma ou outra afastam o processo de seu propósito. $\mathrm{Na}$ realidade, mais do que teorias, serão analisadas posições sobre o papel do instrumentoprocesso que ganharam força ao longo do tempo, e que hodiernamente já se infiltraram em grande parte dos estudos doutrinários, bem como na jurisprudência de nosso país.

Espera-se que com a abordagem dos entraves que impedem a identificação do caráter teleológico do processo sejam abertos caminhos para uma melhor compreensão da

\footnotetext{
${ }^{7}$ GRINOVER, Ada Pellegrini; FERNANDES, Antonio Scarance; GOMES FILHO, Antonio Magalhães. As nulidades no processo penal, cit., p. 27.

${ }^{8}$ Cabível, aqui, a lição de Alberto Binder, até como justificativa do presente capítulo: "se no está claro lo que deben proteger las formas procesales, entonces protegerán la rutina, los ritos y los ritmos de la burocracia judicial." (El incumplimiento de las formas procesales, cit., p. 43).
} 
teoria das nulidades, e consequentemente, da categoria do prejuízo, a qual, por sua vez, consoante já se disse, encontra-se defasada nos moldes atuais.

\subsection{A evolução do processo penal: a atual compreensão de seu caráter instrumental}

Houve um tempo em que processo penal era dispensável. Os conflitos de interesses eram dirimidos pelas próprias partes envolvidas, as quais, sem se subordinarem a uma figura desinteressada e imparcial, impunham suas próprias "penas", mediante o uso da força, para chegarem ao que se entendia à época por justiça. ${ }^{9}$

Com a consolidação do Estado moderno, no entanto, nasce também a necessidade de criação de mecanismos para contenção das pretensões particulares de seus súditos. A própria existência e manutenção de um poder estatal centralizado pressupunha a supressão da vingança privada, e retirava progressivamente da parte envolvida o controle da pena, inserindo, em seu lugar, um órgão soberano encarregado de exercer, com exclusividade, o poder punitivo. ${ }^{10}$ Destarte, o processo penal surge com a finalidade inicial de estruturar uma forma - e apenas uma delas ${ }^{11}$ - pela qual o Estado possa conter a retribuição vingativa dos cidadãos, impedindo a continuidade da administração da justiça sob o modelo da autotutela.

Desde então, e no transcorrer dos anos, o processo penal vem assumindo feições diferentes; desempenha funções as mais diversas a depender das circunstâncias de tempo e espaço em que é aplicado, sobretudo pelo caráter político que lhe é ínsito. ${ }^{12}$ Nas palavras de Antonio ScARAnce Fernandes, a história do processo penal é marcada por movimentos pendulares, ora se assentando em ideais repressivos, estreitamente ligados à

\footnotetext{
${ }^{9}$ HERTEL, Daniel Roberto. Técnica processual e tutela jurisdicional: a instrumentalidade substancial das formas. Porto Alegre: Sérgio Antonio Fabris Editor, 2006. p. 19. Valiosas, também, as lições de Nereu Giacomolli: "Nas comunidades primitivas, a força privada, inclusive o uso da força física (vingança, duelo), era utilizada como satisfação de um interesse individual ou do grupo social, preponderando a vontade do mais forte ou de quem o mais forte protegesse. A autodefesa constituía-se em uma forma natural de reação do sujeito lesionado." (O devido processo penal. São Paulo: Atlas, 2014. p. 401).

${ }^{10}$ LOPES JÚNIOR, Aury. Direito processual penal e sua conformidade constitucional. 7. ed. Rio de Janeiro: Lumen Juris, 2011. v. 1, p. 4.

${ }^{11}$ Sobre a forma como o Direito Penal, inicialmente, foi imposto ao cidadão, Basileu Garcia pontua: "Em tempos idos, o Direito Penal era arbitrário, tirânico. A autoridade pública aplicava discricionariamente as penas, sem que leis obrigatoriamente as preestabelecessem. Bastavam certas fórmulas imprecisas. O cidadão, ao qual fosse imputado um fato, nem sempre poderia defender-se afirmando que tal ocorrência não se circunscrevia a nenhuma figura delituosa especialmente prevista." (Instituições de direito penal. 7. ed. São Paulo: Saraiva, 2008. v. 1, t. 1, p. 13).

${ }^{12}$ Descrevendo a ligação da justiça com política, Calamandrei lembrava que o juiz, qualquer que fosse ele, levava em conta seus próprios sentimentos, como um homem político que vivesse em sua sociedade, e que participasse da dinâmica econômica e moral desta, com as próprias repugnâncias e mitos de sua época. (Processo y democracia. Tradução Hector Fix Zamudio. Buenos Aires: Ediciones Jurídicas, 1960. p. 66-67).
} 
segurança social, ora dando prevalência a pensamentos mais garantistas, cuja preocupação precípua seria assegurar os direitos individuais do acusado. ${ }^{13}$

Depreende-se daí, inicialmente, a dificuldade de se identificar, de maneira conclusiva, a função do processo penal. A constante mutação de suas bases estruturantes que se movem ao sabor do próprio dinamismo da sociedade - impossibilita que se aponte um só objetivo para existência do processo.

Com efeito, a análise teleológica do processo penal não é estática; ela há de ser feita levando em conta as particularidades dogmáticas, principiológicas e políticas de um modelo adotado em uma determinada época. ${ }^{14}$ Compreender a que se destina o processo penal, em última análise, é desvendar também o grau de desenvolvimento de uma sociedade àquele tempo. ${ }^{15}$

Necessário reassegurar, a fim de se partir de um ponto inicial para identificação da finalidade dessa ciência, que o processo penal constitui um instrumento, sendo esse um dos motivos primordiais para sua existência. ${ }^{16} \mathrm{O}$ direito penal material prescreve inúmeras condutas humanas socialmente reprováveis (tipos penais), para as quais determina uma sanção. Referida reprimenda, para ser legítima e válida, somente poderá ser imposta se respeitadas as regras prefixadas por meio do processo penal. ${ }^{17}$ Assim, é o processo um instrumento indispensável à pena.

A sustentar o contrário, estar-se-ia prestando homenagem à visão autonomista da história do direito processual, de manifesta postura técnica, a qual concentrava os estudos exclusivamente nos institutos processuais, negando a estreita vinculação entre pena e

\footnotetext{
${ }^{13}$ FERNANDES, Antonio Scarance. Processo penal constitucional. 7. ed. São Paulo: Ed. Revista dos Tribunais, 2012. p. 23.

14“ $\mathrm{O}$ mais que pode dizer-se é que, tendo de dar solução, a tantas tensões e conflitos que se geram no seu seio, deve ele por força estruturar-se dialecticamente e de molde a prestar a mais atenta consideração às diferentes possibilidade e pontos de vista que se lhe oferecem num momento dado." (DIAS, José de Figueiredo. Direito processual penal. Coimbra: Coimbra Ed., 1974. v. 1, p. 50).

${ }^{15}$ É por essa razão que James Goldschmidt afirma que a estrutura do processo penal de uma nação constitui o termômetro dos elementos corporativos ou autoritários de sua constituição. (Problemas jurídicos y políticos del proceso penal. Barcelona: Bosch, 1935. p. 67).

${ }^{16} \mathrm{Cf}$. LOPES JÚNIOR, Aury. Direito processual penal e sua conformidade constitucional, cit., v. 1, p. 26.

${ }^{17}$ Sobre a instrumentalidade do processo, Ricardo Gloeckner ressalta que "em termos amplos, a instrumentalidade do processo corresponde à característica que a torna uma peça dinâmica, a fim de dar vida ao "direito material." (Nulidades no processo penal: introdução principiológica à teoria do ato processual irregular, cit., p. 28).
} 
processo. ${ }^{18}$ Havia, à época, um extremado apego à forma, que conferia ao processo uma natureza de relação jurídica, ${ }^{19}$ com pouca ênfase no seu aspecto teleológico.

Imperioso, portanto, que se negue qualquer tentativa de estabelecer o processo como um fim em si mesmo, evitando-se o abuso de conceitualismos e abstrações dogmáticas. ${ }^{20}$ Ao contrário, imprescindível que o processo penal seja estudado de uma perspectiva exterior, examinando sua inserção na ordem jurídica, política e social, sem deixar de lado a funcionalidade de seus institutos para consecução de finalidades extraprocessuais.

Tarefa das mais complexas, todavia, é estabelecer o conteúdo dessa instrumentalidade, sem se descuidar de suas bordas (limitações). De nada adianta dizer que o processo é um caminho indispensável para imposição de uma sanção penal, sem que se identifiquem as características e, sobretudo, os pontos de apoio dessa trilha a ser percorrida. Nas palavras de DINAMARCO, "falar em instrumentalidade exige que se esclareça também qual a tarefa que se pretende através do instrumento considerado, ou seja, qual o fim, ou fins, a serem obtidos através do emprego do meio."21

Apontar as bases sobre as quais repousa a instrumentalidade do processo penal há de ser o norte para distingui-lo dos outros ramos do direito, bem como para estabelecer seu papel na constante tensão entre o ius puniendi e os direitos individuais do acusado. Ressalte-se que o motivo da existência do processo penal autônomo não é unívoco. ${ }^{22}$ Explicá-lo a partir de um só viés, para muito além de uma leitura míope e simplista de um fenômeno indiscutivelmente complexo, significaria escamotear parte essencial de sua própria existência.

Adiante-se, desde logo, que a função do processo penal não pode ser a de somente viabilizar (legitimar) a imposição de uma sanção, o que o confundiria com uma espécie de

\footnotetext{
${ }^{18}$ DINAMARCO, Candido Rangel. A instrumentalidade do processo. 14. ed. São Paulo: Malheiros Ed., 2009. p. 317.

${ }^{19}$ A concepção do processo como relação jurídica foi inicialmente estruturada por Oskar Van Bulow, na obra Teoria dos pressupostos processuais e das exceções dilatórias. A partir desse estudo, a doutrina diz que se inicia o período cientificista do processo, passando os estudiosos a se dedicarem ao processo como ciência autônoma, desvinculada do direito substancial.

${ }^{20}$ BARBOSA MOREIRA, José Carlos. Notas sobre o problema da 'efetividade' do processo. Ajuris, Porto Alegre, v. 29, p. 77, 1983.

${ }^{21}$ DINAMARCO, Candido Rangel. A instrumentalidade do processo, cit., p. 365

${ }^{22}$ DIAS, Jorge Figueiredo. Direito processual penal. Coimbra: Coimbra Ed., 2004. v. 1, p. 41.
} 
motor da punição. ${ }^{23}$ Esse, quando muito, poderia constituir uma das finalidades do processo, mas, nem de longe, a única, tampouco a mais relevante.

Aliás, se é próprio do Estado o poder de punir, tendo ele, inclusive, domínio soberano sobre todos os seus súditos, por qual motivo necessitaria provar seu direito em um processo ${ }^{24}$ Em outros termos, o processo penal não pode ser entendido exclusivamente como instrumento de persecução do réu. Fosse esse o caso, desnecessária a existência do processo, já que o próprio Estado, detentor do poder punitivo, poderia lançar mão da punição sumariamente, demonstrando seu poder em detrimento do seu "súdito transgressor".

Conforme se verá no decorrer do capítulo, o instrumento-processo deve estar permeado e limitado pelos direitos e garantias fundamentais, e por isso umbilicalmente vinculado à Constituição da República. Ele é, antes e primordialmente, um caminho indispensável para garantia do acusado contra o poder arbitrário do Estado, ${ }^{25}$ e constitui genuíno freio de proteção dos inocentes frente à atuação do poder público. ${ }^{26}$ Antes de se chegar a tal conclusão, no entanto, imprescindível proceder à análise de algumas questões alastradas no âmbito dogmático, as quais retiram de foco a verdadeira função do processo penal.

\subsection{Teoria Geral do Processo e a Inadequação de uma Instrumentalidade Universal}

Inicialmente, e antes de se passar ao estudo específico da instrumentalidade do processo penal, forçoso dedicar breves linhas a respeito da construção doutrinária do que se convencionou denominar de teoria geral do processo. Se é a compreensão da exata função do processo penal que se pretende no presente capítulo, impossível deixar de destacar como, ao longo dos anos, em virtude de uma concepção unitária processual, houve

\footnotetext{
${ }^{23}$ A expressão foi utilizada por Ricardo Jacobsen Gloeckner (Nulidades no processo penal: introdução principiológica à teoria do ato processual irregular, cit., p. 31) para criticar concepção de um processo penal voltado somente para punição dos indivíduos acusados.

${ }^{24} \mathrm{~A}$ indagação foi primeiramente feita por James Goldschmidt, a quem parecia pouco lógico ser a finalidade do processo unicamente possibilitar a aplicação de uma pena (Problemas jurídicos y políticos del proceso penal, cit., p. 67).

${ }^{25}$ GRINOVER, Ada Pellegrini. Liberdades públicas e processo penal. 2. ed. São Paulo: Ed. Revista dos Tribunais, 1982. p. 20.

${ }^{26}$ CARRARA, Francesco. Il diritto penale e la procedura penale. In: CARRARA, Francesco. Opuscoli di diritto criminale. Prato: Tip. Giachetti Figlio, 1881. v. 5, p. 10.
} 
uma invasão, sem maiores cuidados, de conceitos e ideias eminentemente privatísticas, que resultou em um claro desvirtuamento da finalidade própria do processo penal. ${ }^{27}$

Como é sabido, não é de hoje que se fala em uma teoria geral do processo, por meio da qual seria possível identificar uma base principiológica, ainda que genérica, bem como regramentos e institutos comuns a ambos os ramos. Sendo una a jurisdição, diriam aqueles que se afiliam à referida teoria geral, uno também haveria de ser o processo. ${ }^{28}$

Partindo-se de uma concepção do processo que gravita em torno da ideia de lide, CARNELUTTI foi quem deu voz mais notável à corrente unitarista do processo, que hodiernamente conta com intensa adesão nos bancos acadêmicos. De acordo com o renomado processualista italiano, tanto ao processo penal, quanto ao processo civil, caberia a solução de uma lide, representada por um conflito de interesses qualificado pela pretensão de um dos interessados e pela resistência do outro. ${ }^{29} \mathrm{Na}$ seara do processo penal, o entendimento assentado, ainda segundo essa definição carneluttiana, era o da existência de um conflito de interesses entre o imputado e a parte lesada. ${ }^{30}$

Por mais contundentes que tenham sido as críticas direcionadas à posição de CARNELUTTI, pela evidente tentativa de se impor uma fórmula jusprivativista ao processo penal, certo é que elas serviram de genuíno motor-propulsor para que a ciência processual fosse compreendida como una. ${ }^{31}$ Deveras, a partir desse momento ganham corpo as mais

\footnotetext{
${ }^{27}$ Discorrendo especificamente sobre a problemática no campo das nulidades, João Conde Correia adverte que "um dos fatores que mais contribuíram para a instabilidade doutrinal, legal e jurisprudencial da teoria da invalidade e das nulidades processuais penais foi, sem dúvida, a importação acrítica dos modelos civilistas clássicos e a sua transposição para o campo processual penal. Ignorando as especificidades e finalidades do processo penal, que aliás legitimam a sua autonomia teleológica, essa adaptação arrastou consigo as virtudes daqueles conceitos, mas também os seus vícios e as suas imperfeições e contagiou toda a teoria da ineficácia dos actos processuais penais com os gérmens da crise que então já se fazia sentir no direito civil." (Contributo para análise da inexistência e das nulidades processuais penais. Coimbra: Coimbra Ed., 1999. p. 15-16).

${ }^{28}$ CINTRA, Antonio Carlos de Araújo; DINAMARCO, Cândido Rangel; GRINOVER, Ada Pellegrini. Teoria geral do processo. 28. ed. São Paulo: Malheiros Ed., 2012. p. 57.

${ }^{29}$ Livre tradução do CARNELUTTI, Francesco. Sistema di diritto processuale civile. Milano: CEDAM, 1936. p. 40.

${ }^{30}$ É preciso registrar que, posteriormente, Carnelutti modificou seu entendimento sobre o tema. No ano de 1941, em sua obra Instituizioni del Processo Civile Italiano, há a formulação de uma segunda teoria, segundo a qual o processo penal seria um gênero misto entre o processo contencioso e o voluntário. Abandona, por consequência, a ideia de lide como conteúdo do processo penal, ressaltando agora o caráter de verificação de uma pretensão penal ou punitiva, independentemente da resistência das partes. Mesmo com a existência de pretensão punitiva, Carnelutti entendia não haver partes opostas no processo penal, tendo em vista o interesse do réu também em sua eventual punição. Para uma visão crítica acerca dessas e de outras formulações do conceito de lide no processo penal, cf. COUTINHO, Jacinto Nelson de Miranda. A lide e o conteúdo no processo penal. Curitiba: Juruá, 1989.

${ }^{31}$ Digno de nota o fato de que alguns países sequer mantêm códigos de processo distintos, como é o caso da Suécia, que aplica o Código de Processo Sueco de 1942 (Rättegangsbalken) tanto para os processos penais, como para os processos cíveis.
} 
diversas correntes que, a despeito de negarem determinados postulados originários da teoria, insistem na ideia de que os diferentes ramos do processo devam ser estudados em conjunto. ${ }^{32}$

Seriam conferidos aos principais conceitos, tais como ação, jurisdição e defesa, definição única, daí porque também se falar em uma elaboração científica da teoria geral do processo. ${ }^{33}$ A própria Constituição Federal pátria, ao tratar da competência legislativa da União e dos Estados, refere-se ao direito processual como matéria una, abrangendo, assim, as espécies processo penal e o processo civil. ${ }^{34}$

É verdade que, no mais das vezes, os cultores do unitarismo processual fazem a ressalva de que não objetivam criar uma identidade absoluta entre os ramos do processo, mas apenas desenvolver linhas mestras aptas a satisfazerem a essência do processo. ${ }^{35}$ Haveria, segundo o escólio de PODETTI, uma trilogia estrutural do direito processual, consubstanciada nos conceitos de ação, jurisdição e processo, que formariam as bases fundantes da teoria geral do processo. ${ }^{36}$

FREDERICO MARQUES pontua que entre o processo de natureza penal e aquele de natureza civil haveria tão somente uma diferença de ordem procedimental, inexistindo, assim, motivos para desconsiderar a unidade do processo. Destaca, ainda, que nem se poderia falar em uma diferenciação com esteio na ideia de interesses privados $\mathrm{X}$ interesses públicos, haja vista que o processo é sempre de direito público, qualquer que seja seu conteúdo. ${ }^{37}$

\footnotetext{
${ }^{32}$ Giovanne Leone, por exemplo, não descarta a ideia de lide no processo penal, mas dá-lhe novos contornos. É dele a construção talvez mais reproduzida nos dias atuais de que existe um conflito permanente, no processo penal, entre o jus puniendi $\mathrm{x}$ jus libertatis. Inexistiria um conflito subjetivo de interesses, mas sim um conflito permanente e indisponível de interesses. Apud, COUTINHO, Jacinto Nelson de Miranda. A lide e o conteúdo no processo penal, cit., p. 96.

${ }^{33}$ Reconhece DINAMARCO, mesmo sendo um dos defensores da teoria geral do processo, que é "ainda incipiente e problemática quanto ao reconhecimento de sua própria legitimidade científica, ela não tem até hoje suas linhas bem definidas, nem o âmbito de abrangência." (A instrumentalidade do processo, cit., p. 67).

${ }^{34}$ CINTRA, Antonio Carlos de Araújo; DINAMARCO, Cândido Rangel; GRINOVER, Ada Pellegrini. Teoria geral do processo, cit., p. 57.

${ }^{35}$ Mesmo nos Estados Unidos da América, há quem defenda uma maior aproximação das duas searas processuais: "Civil and criminal procedure still have a lot in common. They are both, after all, systems of adjudicating - or otherwise resolving - disputes, and settling - or sidestepping disagreements about historical facts. They both aim at fairness, accuracy, and efficiency - albeit in different mixtures." (SKLANSKY, David Alan; YEAZELL, Stephen C. Comparative law without leaving home: what civil procedure can teach criminal procedure, and vice versa. The Georgetown Law Journal, v. 94, p. 684, 2006). ${ }^{36}$ PODETTI, Ramiro. Teoria y tecnica del proceso civil y trilogia estructural de la ciencia del proceso civil. Buenos Aires: Ediar, 1963. p. 339.

${ }^{37}$ MARQUES, José Frederico. Da unidade do processo - aplicação de conceitos do processo civil no campo do processo penal. In: Estudos de direito processual penal. 2. ed. Campinas: Millenium, 2001. p. 10. O autor, no mesmo texto, assevera que "a separação estanque dos dois processos é fruto de equívocos, e não de amadurecido estudo do assunto. O direito processual é um só, porquanto disciplina o exercício de uma atividade estatal, também una, qual seja a jurisdição. Julgar é aplicar os mandamentos do direito objetivo, tanto na justiça penal, como na justiça civil (p. 10).
} 
Por outro lado, há aqueles que não se afinam com a teoria unitária do processo, entendendo que cada ramo guarda particularidades incompatíveis com a formulação de uma teoria geral. ${ }^{38}$ De acordo com tal posicionamento, a conjugação dos estudos e a consequente aplicação indiscriminada de institutos típicos do processo civil têm gerado uma perigosa e insustentável desvirtualização do correto escopo do processo penal. ${ }^{39}$

Inexistiria no processo penal, de acordo com os dualistas, o conceito de lide, sendo ele próprio do processo civil. ${ }^{40} \mathrm{~A}$ jurisdição penal pressupõe uma tutela de interesses indisponíveis, pouco importando se haja, ou não, resistência das partes. ${ }^{41} \mathrm{O}$ conflito de interesses, caracterizador da existência da lide, poderia até ser verificado em determinados casos penais, porém não seria suficiente para identificar o verdadeiro conteúdo do processo penal, em todas as suas formas e fases. ${ }^{42}$

Afora a inaplicabilidade do conceito de lide no processo penal, a doutrina identifica outros aspectos inconciliáveis nas duas disciplinas. TUCCI, em trabalho dedicado ao tema, afasta a acepção civilística de pretensão ${ }^{43}$ no processo penal, bem como menciona que, diferentemente do que ocorre no processo civil, no processo de natureza penal inexiste uma ação autônoma cautelar, bem como o julgamento de um réu à revelia. ${ }^{44}$

\footnotetext{
38، A teoria geral do processo como construção do período cientificista angariou os mais diversos nomes. Poucos aqueles autores que ousaram denunciar a equivocada trama de conceitos, obumbrados pela inadequação não apenas teórica, mas que possibilitou um sem número de equívocos no plano judicial." (GLOECKNER, Ricardo Jacobsen. Nulidades no processo penal: introdução principiológica à teoria do ato processual irregular, cit., p. 50).

${ }^{39}$ Rogério Lauria Tucci, defensor assíduo da ideia da necessária separação entre os dois ramos do processo, acentua que há um movimento para tentar "civilizar" o processo penal. Refere-se, inclusive, a uma denominada teoria civil do processo penal. (Considerações acerca da inadmissibilidade de uma teoria geral do processo. In: PIERANGELI, José Henrique (Coord.). Direito criminal. Belo Horizonte: Del Rey, 2001. v. 3, p. 126).

${ }^{40}$ Para Gustavo Badaró (Processo penal. Rio de Janeiro: Campus: Elsevier, 2012. p. 397), "a origem de todas as dificuldades de se adaptar o conceito de lide ao processo penal está, ao que parece, no fato de se tentar transpor um conceito do mundo privatístico, mais precisamente do campo obrigacional, em questão de inadimplemento contratual, para a seara penal, pública e indisponível por natureza."

41، 'A razão pela qual o conceito de lide não é utilizável no processo penal, como elemento distintivo da função jurisdicional, é aquela desenvolvida por Calamandrei. Estão em jogo interesses indisponíveis. O processo penal não tem a finalidade de remover qualquer desacordo entre o julgador e o acusado sobre a existência do crime ou da medida da pena, de modo que o processo perderia sua razão de ser onde o desacordo fosse amigavelmente composto entre os dois litigantes". (LEITE, Luciano Marques. O conceito de "lide" no processo penal: um tema de teoria geral do processo. Justitia, São Paulo, n. 70, p. 81, jul./set. 1970).

${ }^{42}$ COUTINHO, Jacinto Nelson de Miranda. A lide e o conteúdo no processo penal, cit., p. 137.

${ }^{43}$ Segundo o autor, seria equivocado falar em pretensão no processo penal, uma vez que a ocorrência de uma infração é, por si só, suficiente para deflagração de um processo. Não haveria lugar, destarte, para uma declaração de vontade impositiva.

${ }^{44}$ TUCCI, Rogerio Lauria. Considerações acerca da inadmissibilidade de uma teoria geral do processo, cit., p. 96 et seq. Eugenio Florian, se debruçando sobre o tema, destacou quatro grandes diferenças entre o processo penal e o processo civil: a) o objeto: no processo penal há uma relação de direito público, ao passo que no processo civil o objeto é sempre, ou quase sempre, uma relação de direito privado; b) indisponibilidade: processo penal é instrumento indispensável para aplicação da lei penal, enquanto o
} 
Lembram, outrossim, os que entendem ser necessário o apartamento completo dos dois ramos processuais, o vínculo mais estreito - quase indissociável - que o processo penal mantém com o direito material, ao passo que no processo civil essa ligação não se revela tão extremada. ${ }^{45}$ Nesse sentido, as exigências para instauração de uma ação de natureza civil se limita a aspectos puramente formais (pressupostos), sendo certo que para a deflagração de uma ação penal, imprescindível ao menos a presença concreta de alguns indícios da existência de direito material. ${ }^{46}$

Em verdade, a discussão acerca da correção e atualidade de uma teoria geral do processo revela-se extremamente polarizada. Ressalvados alguns parcos argumentos tendentes a buscar uma justificativa lógica para apoiar os mais variados pontos de vista, o que se verifica é um maniqueísmo exacerbado e despropositado, por meio do qual os trabalhos doutrinários, ou propõem a emancipação por completo do processo penal em relação ao processo civil, ou então dizem ambos pertencerem a uma mesma espécie (Direito Processual).

Note-se que pouco se discute a respeito da (in)aplicabilidade de institutos específicos do processo civil no processo penal, ou mesmo o reverso, limitando-se as considerações, com as devidas exceções, a se centrarem em ideias como lide, ou a extensão do princípio dispositivo de cada ramo processual. Ao que parece, os pontos nevrálgicos escolhidos para o embate entre unitaristas e dualistas residem, no mais das vezes, em aspectos gerais da ciência processual, da mesma maneira como ocorria em tempos vetustos.

Defender o todo ou o nada não deve ser, com o devido respeito aos que pensam diversamente, a trilha a ser seguida na matéria sob comento. Incontáveis esforços argumentativos foram depositados em teses para dizer se haveria, ou não, sentido em uma teoria geral do processo, sendo que o que se deixou de lado foi justamente uma análise mais aprofundada no que diz respeito às particularidades de cada instituto processualpenal, e as razões pelas quais eventualmente não se aplicam ao processo civil.

processo civil nem sempre é necessário para fazer valer as relações de direito privado; c) poder dispositivo das partes: no processo penal, o poder dispositivo se revela muito limitado, sendo que no processo civil esse poder é total; e d) critérios para julgamento: o juiz civil é regido por critérios exclusivamente jurídicos, ao passo que no processo penal o juiz julga um homem, e por isso, pode se valer de critérios ético-sociais. (Elementos de derecho procesal penal. Trad. Leonardo Prieto Castro. Madrid: Bosch, 1934. p. 22).

${ }^{45}$ PORTO, Pedro Rui da Fontoura. Considerações sobre a impossibilidade de uma teoria geral do processo penal e civil a partir da investigação acerca do conteúdo do processo penal. Revista do Ministério Público, Porto Alegre, n. 49, p. 225, 2003.

${ }^{46}$ GOMES ORBANEJA, Emilio. Comentarios a la Ley de Enjuiciamiento Criminal. Barcelona: Bosch, 1947. t. 1, p. 35-36. 
Por óbvio que não há quem possa sustentar inexistirem pontos de convergência entre os distintos ramos processuais. ${ }^{47} \mathrm{~A}$ atuação jurisdicional, qualquer que seja ela, reclama uma série de pressupostos que, per se, já demonstram ao menos aspectos mínimos comuns entre o processo civil e o processo penal. ${ }^{48} \mathrm{~A}$ incoerência de se falar em lide, na seara penal, por exemplo, é insuficiente para afastar por completo uma teoria geral do processo.

Ademais, cumpre registrar a existência histórica de relevantes e fecundos estudos no âmbito do processo civil os quais ajudaram a desenvolver, e muito, a ciência processual penal. Declarar a emancipação completa do processo penal significaria dizer, por consequência lógica, serem inúteis as contribuições importadas do processo civil, bem como reconhecer a impossibilidade de utilização dos ensinamentos desse ramo específico no processo penal. De nada adianta negar por completo a similitude entre as espécies de processo, e no momento em que for conveniente citar os ensinamentos dos processualistas civis.

De outro lado, contudo, não se afigura razoável a construção de uma teoria geral despreocupada com as peculiaridades dos ramos distintos. Inaceitável, nessa senda, mas que não raras vezes ocorre, é o tratamento do processo penal como forma de complemento do processo civil, colocando aquele em segundo plano, quase como se tivesse sido absorvido pelo processo civil. ${ }^{49}$

Se inegavelmente existem determinados institutos processuais que podem ser estudados em conjunto, há outros tantos que merecem um tratamento autônomo, de modo que não se transportem ao processo penal figuras que com ele não sejam compatíveis. ${ }^{50}$

47،...no podemos separar completamente a los procesos civil y penal (o no penal y penal). Pues es grande la zona intermedia, aquella en que la acción punible lesiona intereses públicos superiores, pero por razones históricas, derivadas de la tradición, del hábito, de las condiciones particulares de los lugares y de los pueblos; en fin, por razones políticas se deja el paso y primacía a los intereses particulares (delitos llamados privados); asimismo, aquellos en que actuaciones no punibles afectan a intereses públicos de modo no dispositivo." (FAIRÉN GUILLÉN, Víctor. El proceso como función de satisfación jurídicas. Revista de Revista de Derecho Procesal Iberoamericana, Madrid, n. 1, p. 393, 1969).

${ }^{48} E$ É evidente que alguns princípios do processo penal são comuns ao processo civil, embora se possa dar a eles extensão ou interpretação diversa em cada um dos ramos. Assim, por exemplo, não há como deixar de falar em princípio da imparcialidade do juiz, princípio do contraditório, princípio do duplo grau de jurisdição, necessidade de motivação da decisão judicial no processo. De se lembrar que o próprio Dinamarco não nega ser a teoria geral do processo uma abordagem genérica sobre o tema: "Teoria geral do processo é, nessa perspectiva, um sistema de conceitos e princípios elevados ao grau máximo de generalização útil e condensados indutivamente a partir do confronto dos diversos ramos do direito processual" (DINAMARCO, Candido Rangel. A instrumentalidade do processo, cit., p. 68).

${ }^{49}$ Aury Lopes Jr, recorrendo à analogia originariamente feita por Carnelutti, se utiliza da imagem da Cinderela para demonstrar como o direito processual penal foi relegado a segundo plano em relação ao direito material e o processo civil. "Cinderela é uma boa irmã, adverte o mestre italiano, e não aspira uma superioridade em relação às outras, senão unicamente uma afirmação de paridade.” (LOPES JÚNIOR, Aury. Direito processual penal e sua conformidade constitucional, cit., v. 1, p. 36).

${ }^{50}$ Luis Eulálio de Bueno Vidigal, ao prefaciar a $1^{\text {a }}$ edição a Teoria Geral do Processo (CINTRA, Antonio Carlos de Araújo; DINAMARCO, Cândido Rangel; GRINOVER, Ada Pellegrini. Teoria geral do 
Não é, destarte, a discussão sobre a (in)existência de uma teoria geral que sanará essas incongruências, mas, sim, o acurado estudo relacionado aos elementos do processo que poderiam eventualmente manter características similares, e aos que, por sua vez, se distinguiriam em demasia, a ponto de a eles ser conferida uma análise autônoma daquele ramo específico. ${ }^{51}$ Caso contrário, permanecer-se-á nessa eterna, e pouco proveitosa, discussão entre unitaristas e dualistas.

Consoante se verá adiante, por exemplo, a aplicação do princípio do prejuízo (pas de nullité sans grief), ponto central do presente estudo, não deve ser alijada, somente pelo mero fato de ter sido transportado do processo civil, do processo penal. Acontece que essa transposição foi realizada de maneira equivocada, sem que houvesse a imprescindível adaptação do instituto ao processo penal, o que gerou uma indisfarçável e perigosa ilegalidade congênita no campo das nulidades, que necessariamente deve ser corrigida. ${ }^{52} \mathrm{O}$ princípio do prejuízo, no ramo processual penal, reclama requisitos próprios, presunções diversas, enfim, roupagem diferente daquela que é concebida no processo civil.

A mesma coisa ocorre na questão da instrumentalidade do processo. Ao se tratar desse tema - cuja imprescindibilidade para o presente estudo já se destacou no item anterior -, mister que seja delineada a sua devida extensão no âmbito do processo penal. Ainda que não se negue a existência de uma teoria geral do processo - o que, para fins do presente trabalho, é indiferente -, certo é que não há que se falar em uma instrumentalidade universal do processo.

processo, cit.) lembra algumas questões que, a despeito do brilhantismo da obra, ficaram sem resposta: "Se o processo tem por escopo a composição da lide, é preciso caracterizar lide e sua composição no processo penal. Que tarefa ingrata! Quais são as partes nesse conflito de interesses? O indiciado de um lado, a vítima, de outro? O indiciado e o Estado? A vítima e o Estado? A Justiça Pública e o indiciado? Quais são os interesses em antagonismo? O interesse do indiciado em sua liberdade e do Estado em seu encarceramento? O interesse da vítima em obter reparação civil e moral e o do indiciado em não lha conceder? O do Estado em proteger a liberdade do cidadão e do criminoso a querer purificar-se pela pena?"

${ }^{51 ، L a}$ existencia de diversas categorías de procesos, cada una con una organización y funcionamiento específicos, a pesar de haber sido todos reconducidos a una idea unitaria común, plantea el problema de saber hasta qué punto nos hallamos en realidad antes distintas divisiones de un mismo concepto o ante conceptos distintos: es lícitos, en consecuencia, hablar de una teoría general del proceso o debemos limitarnos a trazar las líneas de las teorías particulares de diversos institutos que sólo el nombre, por razones no de lógica exclusiva, tendrían en lo fundamental de común?" GUASP DELGADO, Jaime. Concepto y método de derecho procesal. Presentación de Manuel Alonso Olea. Madrid: Civitas, 1997. p. 50.

52 "O problema é grave, mais grave ainda quando assistimos à imensa parcela da doutrina (e, por consequência do ciclo vicioso [senão incestuoso], também da jurisprudência invocando o pomposo (mas absolutamente inadequado para nós do processo penal) pas de nullité sans grief para tratar das nulidades, bem como fazer inadequadas relativizações." (LOPES JÚNIOR, Aury. Direito processual penal e sua conformidade constitucional, cit., v. 1, p. 35). 
Que todo e qualquer processo, independentemente do ramo estudado, não é um fim em sim mesmo constitui, nos dias atuais ao menos, uma afirmação incontestável. ${ }^{53}$ Mas também daí não se pode concluir automaticamente haver uma instrumentalidade geral, aplicável tanto ao processo civil, quanto ao processo penal.

Impende registrar, por oportuno, que cuidar de instrumentalidade no âmbito do processo é buscar também o sentido teleológico de sua existência. ${ }^{54}$ É compreender, dentro de um ordenamento jurídico, com que finalidade foi esse instrumento colocado à disposição da sociedade, bem como identificar o que e a quem protege. ${ }^{55}$

Não se afigura razoável, partindo dessa premissa ainda que simplista do conceito, que se possa sustentar uma instrumentalidade geral, igualmente aplicável ao processo penal e ao processo civil. A cada um deles é conferido um escopo de atuação jurisdicional próprio, tutelando bens obviamente diversos, ${ }^{56}$ sendo verdadeiramente ilógico designar um fim-último comum a ambos os ramos. ${ }^{57}$

Importa recordar que o processo civil coloca-se como instrumento para busca de uma composição entre duas partes em igualdade (ao menos, teoricamente) de condições. Esse meio encontrado pelo Estado, como um dos legitimados para solução de conflitos de natureza civil, propõe-se, através de regras pré-estabelecidas, a apenas mediar essa questão central discutida (lide), dando a ela a resposta mais justa possível. ${ }^{58}$

\footnotetext{
${ }^{53}$ Denilson Feitoza adverte que "o processo penal não é um fim em si mesmo, mas um procedimento destinado a cumprir sua dupla finalidade de garantia da liberdade (prevalecente) e de instrumento de aplicação do direito penal." (Direito processual penal: teoria, crítica e práxis. 5. ed. Rio de Janeiro: Impetus, 2008. p. 118).

54،A forma, o lugar e o tempo dos atos processuais são determinados com critério teleológico, isto é, para o fim de assegurar certos bens jurídicos que a lei reputa politicamente necessários ou tecnicamente convenientes." (TORNAGHI, Helio. Curso de processo penal. São Paulo: Saraiva, 1980. v. 2, p. 293).

${ }^{55}$ É por isso que vale, aqui, novamente recorrer às precisas palavras de João Conde Correia (Contributo para análise da inexistência e das nulidades processuais penais, cit., p. 15), o qual adverte que "a autonomia teleológica do direito processual penal tem um valor prático insofismável, sobretudo ao nível da aplicação analógica das normas processuais civis no campo processual penal (...) Lamentavelmente alguma jurisprudência menos avisada, talvez por comodismo intelectual ou simples conveniência, tem procedido a uma aplicação indiscriminada de normas que muitas vezes apenas têm em comum tratar-se de preceitos de natureza adjectiva."

${ }^{56}$ Não se ignora que o processo penal pode, por vezes, também cuidar de assuntos não relacionados à liberdade do indivíduo, assim como ocorre, por exemplo, na decretação de medidas cautelares reais ou mesmo na condenação por reparações de danos (art. 387, III, do CPP). Todavia, essa não é a regra e tampouco o motivo fulcral para existência do processo penal.

${ }^{57}$ James Goldschmidt, remetendo-se às ideias de Aristóteles de justiça distributiva e justiça corretiva, leciona que a jurisdição penal é a antítese da jurisdição civil (Problemas jurídicos y políticos del processo penal, cit.).

${ }^{58}$ Registre-se que há, na doutrina, duas posições divergentes sobre o real escopo do processo civil. Para a corrente objetivista (Chiovenda), o processo tem como fim fazer atuar a lei. A finalidade seria satisfazer o interesse público e assegurar a paz jurídica. Já a corrente subjetivista (Emilio Betti) considera o escopo do processo a pretensão do autor da demanda, que pode ser procedente ou não. Para uma abordagem mais
} 
Por outro lado, o processo penal desempenha papel diverso, pois atua em um campo no qual uma parte (acusado) está em evidente desvantagem em relação à outra (Estado). É imprescindível que, nesse cenário, encontrem-se meios - e aqui reside uma das finalidades do processo penal - para que haja um equilíbrio no jogo entre as partes, divergindo, já a partir desse ponto inicial, a visão teleológica dos dois ramos de processo. ${ }^{59}$

Ainda que inegável ser o processo, em sua acepção genérica, mais um instrumento a serviço da justiça, não se pode olvidar, de igual forma, que é no âmbito penal que ele revela seu caráter de imprescindibilidade. ${ }^{60}$ Ensina LEONE que a instrumentalidade do processo penal se diferencia dos outros ramos do direito, já que a norma penal material prevê um comportamento proibido, cuja sanção deve necessariamente ser aplicada pelo Estado. Impossível a aplicação da pena sem a existência do processo, mesmo que haja consentimento do acusado. ${ }^{61}$

Destarte, é no princípio da necessidade que o processo penal encontra sua maior distinção em relação ao processo civil, tornando o lastro instrumental do primeiro mais forte do que o do segundo. ${ }^{62}$ Não por outro motivo CONSO e GALlo destacam o aludido princípio como sendo o real caráter distintivo entre os dois ramos processuais. ${ }^{63}$

Ressalte-se que a instrumentalidade do processo penal, e os fundamentos para uma visão constitucional da matéria, serão detidamente abordados adiante no presente capítulo.

completa sobre as diferentes posições frente à finalidade do processo civil, cf. ALVIM, José Eduardo Carreira. Elementos de teoria geral do processo. 2. ed. Rio de Janeiro: Forense, 1993. p. 29-34. DINAMARCO assinala que a jurisdição não tem um escopo, mas inúmeros escopos. Para o brilhante processualista, existem os escopos sociais, políticos e jurídicos da jurisdição. (A instrumentalidade do processo, cit., p. 374).

${ }^{59}$ Ricardo Jacobsen Gloeckner, depois de revelar a condição de hipossuficiente que o acusado mantém em relação ao Estado, propõe uma instrumentalidade que proteja o equilíbrio processual. (Nulidades no processo penal: introdução principiológica à teoria do ato processual irregular, cit., p. 429 et seq.)

${ }^{60}$ Diria Gloeckner que no processo penal a instrumentalidade se acentua a ponto de se poder afirmar que o direito penal possui uma dependência umbilical com o processo. (Nulidades no processo penal: introdução principiológica à teoria do ato processual irregular, cit., p. 28).

${ }^{61}$ LEONE, Giovanni. Elementi di diritto e procedure penale. Napoli: Jovene, 1961. p. 89.

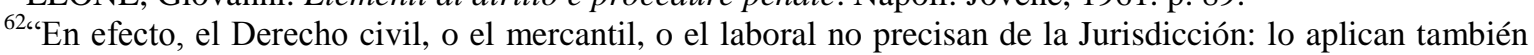
los particulares en su vida diaria (cuando contratan, contraen matrimonio o hacen testamento). No sucede lo mismo sin embargo, con el Derecho penal, que requiere de un proceso en el que Jueces y Tribunales ejerzan la jurisdicción (nulla poena, sine praevio processo)". ARMENTA DEU. Teresa. Lecciones de derecho procesal penal. 3. ed. Madrid: Marcial Pons, 2007. p. 25.

${ }^{63}$ GALLO, Marcello; CONSO, Giovanni. Instituzioni di diritto e procedura penale. Milano: Giuffrè, 1964. p. 5. Vem a calhar, também sob essa óptica, as precisas palavras de Emilio Orbaneja e Vicente Quemada: "Existe una profunda diferencia en este respecto con la relación que une el derecho privado y el proceso civil. Mientras que en el campo privado, por regla general, los derechos son satisfechos y las obligaciones cumplidas espontánea y libremente, sin necesidad del proceso, y tan sólo se acude al juez en caso de incertidumbre o incumplimiento, el derecho penal, para realizarse, necesita siempre ser declarado una sentencia. Ni el propio Estado ni el presunto culpable pueden renunciar al proceso, imponiendo o aceptando la pena sin él." (Derecho procesal penal. 7. ed. Madrid: Ediciones Madrid, 1972. p. 1). 
Por ora apenas se faz necessário consignar que a condensação dos estudos, por meio de uma teoria geral do processo, pode ter alguma utilidade até determinado ponto, sendo, no entanto, impossível se falar em uma instrumentalidade universal do processo, sob pena de se aviltar a autonomia funcional e teleológica de ramos distintos.

\subsection{A Instrumentalidade Inquisitória: em busca da superação de dogmas inexequíveis}

Na trilha para a busca de uma (possível) compreensão da instrumentalidade própria do processo penal moderno, inevitável que se debruce sobre posicionamentos que, longe de verem o acusado como um elemento crucial para desenvolvimento da ciência processual, pautam-se em critérios absolutamente impessoais e abstratos para estabelecer a função da atividade persecutória.

Lastreados em ideais próprios de um modelo inquisitivo, bem como importando conceitos de outros ramos do direito, não são poucos os que defendem ser o processo penal um instrumento a serviço (i) da descoberta da verdade absoluta dos fatos supostamente criminosos, ou (ii) da consecução de fins coletivos, tais como bem-estar comum, paz social. Ver-se-á, contudo, que o processo penal não se presta a exercer referidas funções.

\subsubsection{A problemática inerente à concepção da verdade real no estudo do processo}

Como é cediço, por meio do processo penal, busca-se reconstruir fatos. Dada uma hipótese inicial de ocorrência de um delito, é com esteio na dinâmica processual e em todas as regras a ela inerentes, que se tentará trazer aos autos um evento do passado, permitindo que o julgador confirme ou não as previsões inicialmente aventadas.

Já é de há muito que se conserva o entendimento - ainda presente em determinadas correntes doutrinárias - de que a revisitação dos fatos pretéritos deva ser levada a efeito, no processo penal, até se descobrir o que se convencionou chamar de "verdade real" do ocorrido. O processo, portanto, seria um instrumento utilizado para descobrir, com exatidão, a verdade incontestável dos fatos apurados, o que equivaleria dizer que os autos refletiriam, tal como um raio-x, o perfeito retrato dos acontecimentos. ${ }^{64}$

\footnotetext{
${ }^{64}$ “No Processo Penal brasileiro vigora o princípio da verdade real, no que tange à produção de provas, consoante se vê no art. 155 do Código de Processo Penal." (MARQUES, José Frederico. Elementos de
} 
Ainda segundo esse pensamento - infelizmente muito difundido -, ao processo civil bastaria alcançar uma verdade dita formal, ou seja, aquela possível dentro dos limites das provas trazidas pelas partes, ao passo que no processo penal, por versar sobre matéria de inegável interesse público, o magistrado não poderia ficar adstrito aos elementos lançados nos autos, sendo ele obrigado a buscar, pelos meios disponíveis, a verdade absoluta fenomênica. ${ }^{65}$ A distinção é feita, vale lembrar, olvidando-se que a verdade é una e indivisível. $^{66}$

Mas que verdade é essa que se quer atingir por meio do processo penal? É possível afirmar peremptoriamente que, em um caso qualquer, a instrução criminal permite que se logre êxito em retratar a eventual conduta criminosa, com todas as suas circunstâncias, como ela de fato ocorre? ${ }^{67}$

A história do termo verdade, no processo penal, remonta a épocas nada saudosas. $\mathrm{O}$ seu alvorecer, não se nega, está umbilicalmente ligado ao sistema inquisitório. A verdade, durante a Inquisição, era a mera reprodução das convicções pessoais do inquisidor, o qual pré-concebia (hipótese) uma versão dos fatos em sua mente, sendo a ele dado poderes irrestritos para investigar as provas que confirmasse a sua ideia inicial. Já se tinha um resultado previamente definido pelo juiz (inquisidor), bastando a ideia da verdade real para que se justificasse a busca desenfreada por elementos que dessem um mínimo esteio à versão hipotética. ${ }^{68}$

\footnotetext{
direito processual penal, cit., v. 2, p. 274). De se consignar, também, a posição de BETTIOL “[...] um princípio fundamental do processo penal é o da investigação da verdade material ou substancial dos fatos em discussão, para que sejam provados em sua subsistência histórica, sem distorções, obstáculos e deformações. Isso compreende que o legislador tenha de eliminar do código toda limitação à prova, e que o juiz tenha de ser deixado livre na formação do próprio convencimento" Apud GOMES FILHO, Antonio Magalhães. Direito à prova no processo penal. São Paulo: Ed. Revista dos Tribunais, 1997. p. 39.

${ }^{65}$ Para uma consulta sobre as obras que defendem a dicotomia verdade formal (direito civil) $\mathrm{x}$ verdade material (direito penal), bem como precedentes jurisprudenciais que também fazem essa diferenciação, ver BADARÓ, Gustavo Henrique Righi Ivahy. Ônus da prova no processo penal. São Paulo: Ed. Revista dos Tribunais, 2003. p. 33. Na doutrina estrangeira: BELTRAN, Jordi Ferrer. Prova e verità nel diritto. Bologna: Il Mulino, 2004. p. 70.

${ }^{66}$ “Sin embargo, objetamos ab initio el incongruo de sostener que puedan existir dos verdad. La verdad es una solo. Por lo tanto, la distinción antes apuntada es incorrecta." DI GIULIO, Gabriel. Nulidades procesales. Buenos Aires: Hammurabi, 2005. p. 51. Essa distinção também é rechaçada por Michelle Taruffo: "Un'altra distinzione priva di fondamento che si può rapidamente accantonare, benché si tratti di um luogo comune assai difuso, è quella che si ponetra verità formale o processuale, che si stabilisce nel contesto del processo, e la verità reale, che verrebbe accertata soltanto fuori del processo." (La semplice verità. Bari: Laterza, 2009. p. 83).

${ }^{67}$ Segundo Gabriel Di Giulio, "La verdad revela un fin tan importante y valioso por sí mismo que podría llevarnos a justificar cualquier medio para acceder a ella. Como Dios, el de verdad es supremo para el hombre." (Nulidades procesales, cit., p. 51).

${ }^{68}$ Daí a expressão "primado das hipóteses sobre os fatos" cunhada por Franco Cordero para representar a concepção de processo da época (Guida alla procedure penale. Torino: UTET, 1986. p. 51).
} 
De se lembrar que o acusado, nesse cenário sombrio, era visto como inimigo ${ }^{69}$ do interesse público, pois constituía genuíno entrave para comprovação da versão acusatória inicialmente proposta, tida como verdadeira. E como o processo inquisitório criou o mito ${ }^{70}$ da perseguição da verdade a todo custo, legítima se tornou a prática de atos tendentes a

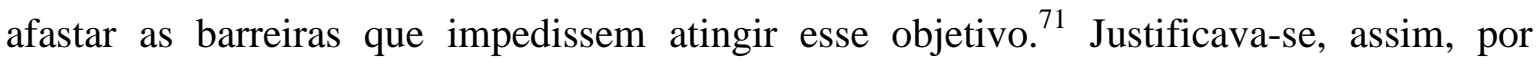
exemplo, a tortura do réu em busca da verdade. ${ }^{72}$

De maneira precisa, LUHMANN lembra que "a posição do valor da verdade e das funções de conhecimento orientadas para ele tem, sem dúvida, raízes antigas no pensamento histórico, não podendo, contudo, ter boas condições de sobrevivência durante tanto tempo porque proporcionava à polêmica contra a burocracia possibilidades de cobertura e apresentação." ${ }^{, 73} \mathrm{E}$, após avaliar as mazelas produzidas em um procedimento legítimo pela ideia de verdade real, conclui o mesmo doutrinador: "Depois disto tudo, torna-se difícil ver qual a outra forma, prescindindo do recurso a uma ideia pré-concebida, de poder estabelecer a opinião de que o conhecimento verdadeiro e a verdadeira justiça constituem o objetivo e conjuntamente a essência dos procedimentos juridicamente organizados, e quando e como se poderia atingir esse objetivo." 74

Fácil de verificar que, além de extremamente perniciosas para existência de um sistema justo de processo penal, as bases sobre as quais se sustentava a busca da verdade real não encontram mais - ou ao menos não poderiam encontrar - amparo na realidade atual. A fantasia de que o processo penal deva ir ao encalço de uma verdade absoluta somente faz sentido a partir do momento em que se acredita ser possível atingir tal nível de conhecimento da verdade.

\footnotetext{
${ }^{69}$ A demonstrar o nível de descrédito dado ao acusado no processo inquisitório, cabe aqui o escólio de Maurício Zanoide de Moraes: "O imputado, já considerado herege já no início da persecução, com a delação ou denúncia pelos membros da comunidade e, portanto, antes mesmo de qualquer investigação, era o ser humano, o portador do 'pecado original' e, exatamente por portá-lo, sempre passível de um mal emergente ao mínimo descuido." (Presunção de inocência no processo penal brasileiro: análise de uma estrutura normativa para a elaboração legislativa e para a decisão judicial. Rio de Janeiro: Lumen Juris, 2010. p. 54).

${ }^{70}$ Para uma compreensão mais aprofundada sobre como a verdade substancial está ligada ao mito, sobretudo, em virtude do constante ocultamento da gênese da ideia do conhecimento absoluto no âmbito do processo penal, frequentemente mencionado como princípio fundante, ver KHALED JR, Salah. Ambição de verdade no processo penal. Salvador: Podium, 2009.

${ }^{71}$ Sobre a verdade no sistema inquisitório, cf. GRINOVER, Ada Pellegrini. Liberdades públicas e processo penal, cit., p. 33.

${ }^{72}$ LOPES JÚNIOR, Aury. Direito processual penal e sua conformidade constitucional, cit., v. 1, p. 551.

${ }^{73}$ LUHMANN, Nicklas. Legitimação pelo procedimento. Trad. Maria da Conceição Côrte Real. Brasilia: Ed. da Universidade de Brasília, 1980. p. 23.

${ }^{74}$ LUHMANN, Nicklas. Legitimação pelo procedimento, cit.
} 
Consoante pontua SALAH KHALED JR., "por incrível que pareça, o direito ainda conserva - em algumas correntes - parte daquela inocência científica típica dos oitocentos, que se encontra ligada à ideia de verdade real, de ausência de interpretação e de correspondência estrita entre o que aconteceu e o que o processo supostamente verificou." 75

A ideia da verdade real representa uma falácia. ${ }^{76}$ Não é crível assumir que a reconstrução fática de um episódio, realizada por meio de um procedimento no qual se verificam tantas variáveis humanas, tendo um histórico de inúmeros erros já comprovados, possa eliminar, in totum, os impedimentos à obtenção da verdade. A certeza absoluta de um fato, desprovida de deficiências, jamais será absorvida pelo juiz e, por consequência, não pode servir de fim-último do processo penal. ${ }^{77}$

Destaque-se que o processo conta com os seus intervenientes (testemunhas, peritos, defesa, acusado, Ministério Público, etc.), os quais, por sua vez, assumem uma realidade do acontecimento que eventualmente seja interessante para si na dialética processual. ${ }^{78}$ Serão essas distintas representações da verdade lançadas nos autos que chegarão ao conhecimento do magistrado, revelando-se genuína ingenuidade acreditar que ele sempre será capaz de criar um retrato fiel, desprovido de parcialidade, dos acontecimentos. ${ }^{79}$

Não fosse apenas sob o aspecto epistemológico, a obtenção da verdade absoluta encontra limitações inerentes ao próprio ordenamento jurídico, mormente após o advento

\footnotetext{
${ }^{75}$ KHALED JR, Salah. Ambição de verdade no processo penal, cit., p. 182.

${ }^{76}$ Importante ressaltar que aqui não se faz qualquer crítica aos que entendem ser a verdade real um princípio reitor do processo penal, até mesmo porque comungam dessa posição doutrinadores de peso. A constatação apenas se limita a propor que é indefensável a ideia de que a verdade, em sua inteireza, possa ser sempre resgatada no decorrer da instrução criminal.

${ }^{77}$ Nas palavras de Francesco Carnelutti, “Quando parti, nos meus estudos sobre processo, com a Prova Civile, falei de verdade, assinalando, como escopo do processo, a investigação da verdade substancial e, como resultado, a obtenção de uma verdade formal. Mas não era, embora algo comum, uma distinção fundada. A verdade não é, e nem pode ser, senão uma só: aquela que eu, como outros chamava de verdade formal, não é verdade. Nem eu sabia, naquele tempo, que coisa fosse e por que, sobretudo, nem com o processo, nem através de algum outro modo, a verdade jamais pode ser alcançada pelo homem." (Verità, dubbio, certezza. Rivista di Diritto Processuale, Padova, v. 20, p. 4, 1965).

${ }^{78}$ Mirjan Damaska (Evidentiary barriers do conviction and two models of criminal procedure: a comparative study. Yale Law School Legal Scholarship Repository, 1-1-1973, p. 578-579) lembra que nos processos modernos a busca pela verdade encontra limitações, sendo que hoje em dia há uma grande preocupação com a condenação de inocentes: "The pursuit of truth in the criminal process is not an untrammeled exercise in cognition. Modern procedures in particular view with much more horror the prospect of convicting an innocent person than they do the prospect of acquitting the guilty. Accordingly, many evidentiary rules presenting obstacles to conviction are inspired by the desire to minimize the chances of convicting an innocent even at the price of increasing chances that a guilty person may escape punishment."

${ }^{79}$ GÖSSEL, Karl Heinz. El derecho procesal penal en el Estado de derecho. Buenos Aires: Rubinzal Culzoni Editores, 2007. p. 105-106.
} 
da Constituição Federal de 1988. As diversas garantias fundamentais previstas no texto constitucional, com efeito, impõem uma natural barreira ao poder instrutório ilimitado de investigação do juiz, o qual, por sua vez, haverá de ficar adstrito a uma verdade permitida pela legislação. ${ }^{80}$

Nos dias atuais, como é cediço, não são poucos os aspectos processuais que obstam o alcance da verdade plena. ${ }^{81}$ A vedação de provas ilícitas (e.g. depoimento obtido mediante tortura), a proibição de revisão criminal pro societate e o direito de o acusado permanecer em silêncio no decorrer da instrução criminal são exemplos ilustrativos de que a verdade, a qualquer custo, não pode ser a finalidade pretendida pelo processo. Falar em verdade material, atualmente, significaria negar a própria aplicação do ordenamento penal vigente. ${ }^{82}$

Sobre o necessário equilíbrio entre a busca da verdade e a limitação da atividade probatória, irrepreensíveis são as palavras de BINDER: "aquí se encuentra una de las grandes tensiones del proceso penal, que se manifiesta en la jurisprudencia sobre ilicitud de la prueba, es decir, aquellos casos en que la actividad procesal debe ser anulada por violación de las formas legales y ello significa algo muy concreto: perder información que puede ser de vital importancia para la construcción de ese relato final." ${ }^{, 83}$

De suma importância a menção de que também não se defende aqui, por outro lado, a tese diametralmente oposta, segundo a qual a ideia de verdade deve ser completamente alijada do processo. Representaria a verdade, para essa determinada corrente doutrinária, algo inatingível, razão pela qual todo e qualquer processo haveria de ser decidido conforme as regras acerca do ônus da prova. ${ }^{84}$

\footnotetext{
${ }^{80}$ Essas limitações normativas, Francisco Muñoz Conde denomina de impurezas processuais ou institucionais à verdade. (La busqueda de la verdade en el proceso penal. 3. ed. Buenos Aires: Hamurabi, 2007. p. 115.) Antonio Magalhães Gomes Filho, denomina esses empecilhos à obtenção da verdade real como limites probatórios de natureza política (Direito à prova no processo penal, cit., p. 93).

${ }^{81}$ Adauto Suannes, com intuito de afastar a ideia de verdade real no âmbito do processo penal, lista inúmeros óbices normativos ao desvelamento de uma verdade absoluta, dentre eles cumpre destacar (i) a inexistência da revisão criminal pro societate, (ii) os prazos preclusivos, (iii) a restrição do mutatio libelli à juízo de primeira instância. (Os fundamentos éticos do devido processo penal. 2. ed. São Paulo: Ed. Revista dos Tribunais, 2004. p. 161-163).

82،"Por otra parte, en el proceso penal existen una serie de límites a la investigación absoluta de la verdad que son consecuencia de la doctrina de la prueba ilícita y de los supuestos en los que se produce la conformidad del acusado y su defensa con las pretensiones acusatorias.” (MIRANDA ESTRAMPES, Manuel. La minima actividad probatoria en el proceso penal. Barcelona: José Maria Bosch, 1997. p. 44-45).

${ }^{83}$ BINDER, Alberto. El incumplimiento de las formas procesales, cit., p. 82.

${ }^{84}$ Para conhecimento das diversas posições que negam a verdade no processo penal, cf. BADARÓ, Gustavo Henrique Righi Ivahy.Ônus da prova no processo penal, cit., p. 20-24.
} 
Renunciar à verdade, no processo, representaria a perda de um referencial de justiça. $^{85}$ Conquanto não se possa concordar, como já sustentado, com uma posição retrógrada de busca, sem freios, de uma verdade infalível, um pronunciamento jurisdicional completamente desvinculado de verdade poderia resultar em um sistema arbitrário de justiça. ${ }^{86}$

O horizonte-verdade, ao menos em alguma medida, deve pautar a atuação dos sujeitos processuais e há de servir como um dos parâmetros ao processo de convencimento do magistrado. ${ }^{87}$ Desempenha, portanto, papel relevante no processo penal, mas não deve ser o fim almejado por ele. ${ }^{88}$

Incoerente seria, há de se convir, um modelo de justiça que admitisse a prolação de uma sentença despreocupada com a correta verificação dos fatos. ${ }^{89}$ Ainda que haja restrições intransponíveis ao conhecimento absoluto dos fatos, o próprio sistema se ocupa em prever inúmeros meios de impugnação para reapreciação fática de decisões judiciais. ${ }^{90}$

Ao processo penal cabe reconstruir, dentro das limitações impostas pela legislação, um episódio do passado da forma que mais se aproxime da realidade dos fatos. Abandonase a ideia de verdade absoluta, já que esta se reveste de utopia, cedendo-se espaço à noção de verossimilhança como grau de conhecimento plausível por meio da ciência processual. ${ }^{91}$

Note-se, nesse contexto, quando se afirma ser um fato verdadeiro, de acordo com PiERo CALAmANDREI, que o que se pretende dizer é que a consciência de quem emite o juízo atingiu o grau máximo de verossimilhança que, segundo os meios probatórios

${ }^{85}$ Embora critique a busca da verdade como único ponto para estruturação de um sistema procedimental, Luhmann (Legitimação pelo procedimento, cit., p. 26) não deixa de lembrar que um sistema completamente desfocado da verdade também não é a solução: "Nenhum procedimento pode prescindir de verdades nesta função específica: doutra forma perder-se-ia num poço sem fundo de possibilidades sempre diferentes. Determinadas observações e determinadas conclusões têm de ser garantidas como obrigatórias."

${ }^{86}$ Segundo Luigi Ferrajoli, "Si una justicia penal completamente con verdad constituye una utopía, una justicia penal completamente sin verdad equivale a un sistema de arbitrariedad." (FERRAJOLI, Luigi. Derecho y razón. 4. ed. Trad. Perfecto Andrés Ibañez; Alfonso Ruiz Miguel; Juan Carlos Bayón Mohino; Juan Terradillos Basoco e Rocío Cantarero Bandrés. Madrid: Trotta, 2000. p. 45).

${ }^{87}$ PLETSCH, Natalie Ribeiro. A atuação dos sujeitos processuais na formação da prova: o magistrado e o alcance da verdade no processo penal. Revista de Estudos Criminais, ano 4, n. 18, p. 231, 2005.

${ }^{88}$ MICHELI, Gian Antonio; TARUFFO, Michele. A prova. Revista de Processo, São Paulo, n. 16, p. 168, out./dez. 1979. Nas palavras de Aury Lopes Jr, "não se nega a verdade, mas tampouco a idolatramos (evitando assim incidir no erro de dar ao processo a missão de revelar a verdade na sentença, o que conduziria à matriz inquisitorial)" (Direito processual penal e sua conformidade constitucional, cit., v. 1, p. 562).

${ }^{89}$ É por isso que Luhmann, em sua obra Legitimação pelo procedimento, cit., sugere que a "verdade" possa constituir uma importante "condição prévia" para determinação do processo. Ou seja, em vez de ser uma finalidade buscada pelo juiz durante a persecução penal, a verdade seria um ponto de referência para confecção das leis.

${ }^{90}$ GOMES FILHO, Antonio Magalhães. Direito à prova no processo penal, cit., p. 54.

${ }^{91}$ Para uma leitura mais aprofundada sobre a ideia de verossimilhança dentro do processo penal, cf. KHALED JR, Salah. Ambição de verdade no processo penal, cit., p. 249-361. 
disponíveis, foi suficiente para dar-lhe certeza da ocorrência do fato. ${ }^{92}$ A certeza, desta feita, caracteriza-se como a segurança subjetiva, pela qual o indivíduo entende ter chegado à verdade de um conhecimento. ${ }^{93}$

É imprescindível avançar nessa matéria e livrar-se das amarras de um modelo inquisitório. De nada adianta manter, ainda que como uma pretensão utópica, um dogma inexequível no âmbito da ciência processual. ${ }^{94}$ A manutenção da compreensão da verdade substancial como alma ${ }^{95}$ do processo penal, para muito além de ser apenas incorreta sob o ponto de vista epistemológico e normativo, é também responsável por gerar decisões as mais esquizofrênicas dentro de nosso sistema. ${ }^{96}$

O motivo maior, contudo, para que não haja um completo abandono da concepção da verdade material como finalidade a ser alcançada pelo processo se deve, e muito, ao vigente - ainda que nada atual - Código de Processo Penal. Mesmo com as alterações pontuais legislativas no decorrer dos anos, bem como com a promulgação de uma Constituição Federal apta a criar as bases principiológicas necessárias para estruturação de um modelo acusatório, há ainda inúmeros dispositivos legais que abertamente permitem entender ser a obtenção de uma verdade absoluta uma função do processo penal.

A começar pela exposição de motivos, ${ }^{97}$ que evidencia o espírito, à época, autoritário do legislador, o intento de se conferir um poder instrutório amplo ao magistrado, aliado a uma máxima desobstrução dos caminhos para alcance de uma

${ }^{92}$ CALAMANDREI, Piero. Verità e verossimiglianza nel proceso civile. Rivista di Diritto Processuale, Padova, v. 20, II série, 1965.

${ }^{93}$ Incabível, no presente trabalho, se estender sobre a matéria. No entanto, para um estudo mais específico acerca do binômio certeza/verdade, cf. CARNELUTTI, Francesco. Verità, dubbio, certezza, cit. Entre nós: VAZ, Denise Provasi. Estudo sobre a verdade no processo penal. Revista Brasileira de Ciências Criminais, São Paulo, n. 83, p. 164-166, 2010.

${ }^{94}$ Segundo Eugênio Florian, a pesquisa da verdade efetiva, material, histórica, constitui o escopo do processo. "A verdade do processo deve aparecer inteira, genuína, sincera, sem manipulações, nem restrições" Apud. GOMES FILHO, Antonio Magalhães. Direito à prova no processo penal, cit., p. 34-35.

${ }^{95}$ Marco Antonio de Barros afirma que houve época em que se atribuía tamanha importância ao princípio da verdade material, que ele se comparava com a própria alma do processo penal. (A busca da verdade no processo penal. 3. ed. São Paulo: Ed. Revista dos Tribunais, 2011. p. 40.)

${ }^{96}$ Apenas a título exemplificativo, há de se consignar duas decisões completamente antagônicas sobre o papel da verdade real, ambas proferidas pelo Superior Tribunal de Justiça. No Habeas Corpus $\mathrm{n}^{\circ}$ 155.149 (rel. Felix Fischer), julgado em 2010, há menção expressa no acórdão, chancelado de forma unânime pela $5^{\mathrm{a}}$ Turma, de que "na realidade, no entanto, é de se gizar, a concepção havida, inclusive, por muitos, como ultrapassada, daquilo que vem a ser verdade real, não é aceita pela dogmática moderna.” Já em sede no HC $\mathrm{n}^{\circ} 196.458$ (rel. Sebastião Reis Junior), julgado em 2012, a Corte se posicionou de maneira diametralmente oposta, asseverando o seguinte: "bem como o de garantir que o processo possa atingir a sua finalidade primordial, qual seja, a busca da verdade real".

${ }^{97}$ Consta da exposição de motivos do CPP: VII - “... Se é certo que o juiz fica adstrito às provas constantes dos autos, não é menos certo que não fica subordinado a nenhum critério apriorístico no apurar, através delas, a verdade material... por outro lado o juiz deixará de ser um expectador inerte da produção de provas. Sua intervenção na atividade processual é permitida, não somente para dirigir a marcha da ação penal e julgar a final, mas também para ordenar, de ofício, as provas que lhe parecerem úteis ao esclarecimento da verdade.” 
imaginada verdade material, permeia o Código de Processo Penal. O diploma adjetivo, assim, não só deixa de criar freios para busca da verdade absoluta, como a estimula em diversas passagens. ${ }^{98}$

Insta salientar que o mito da verdade substancial no âmbito do processo penal influencia sobremaneira o estudo de nulidades. Não se pode conceber uma teoria minimamente racional dos atos defeituosos partindo-se da falsa premissa de que incumbe ao processo penal a descoberta da verdade real. As formas prescritas em lei, para realização dos atos processuais, seriam inócuas, podendo ser sempre justificada a sua inobservância em nome de um bem maior: a verdade. ${ }^{99}$

É justamente o que faz o Código de Processo Penal quando, em seu artigo 566, ${ }^{100}$ dispõe que somente se reconhecerá a nulidade quando o ato potencialmente nulo houver influído na verdade substancial ou na decisão da causa. O dispositivo legal, de garras inquisitórias afiadíssimas, ${ }^{101}$ vincula a verdade dos acontecimentos com o ato nulo, como se a afetação da primeira constituísse genuíno pressuposto para existência do segundo. ${ }^{102}$

Em tese, um vício - por maior o seu desvio em relação ao modelo legal - que, sob a visão do juiz, não houver influído na verdade dos fatos poderá ser considerado como irrelevante. Considerando que, conforme se verá adiante, a própria definição de nulidade absoluta atualmente é incerta, abre-se uma margem perigosa para que o magistrado se posicione conforme a utilidade (necessidade) do caso para afirmar se determinado ato gerou, ou não, algum óbice à obtenção da verdade.

\footnotetext{
${ }^{98}$ Cite-se, apenas como exemplo, alguns dispositivos que autorizam o juiz a determinar, ex officio, a produção de provas: art. 149 (exame médico-legal para inimputáveis); art. 168 (exame pericial em lesões corporais); art. 196 (novo interrogatório).

${ }^{99}$ Ricardo Gloeckner, ao lançar crítica sobre a ideia de verdade substancial, afirma: "A busca pela verdade deve ultrapassar formas e ritos, regras e silogismos. Tudo quanto baste para instituir-se uma verossimilhança entre o episódio fático e os significantes processuais guarda respeito à cacofonia paranoica. Mundos, realidades, discursos constituem um mesmo caldo saturado pela voracidade de saber." (Nulidades no processo penal: introdução principiológica à teoria do ato processual irregular, cit., p. 200-201).

${ }^{100}$ Art. 566, CPP: "Não será declarada nulidade de ato processual que não houver influído na apuração da verdade substancial ou na decisão da causa."

${ }^{101}$ Aury Lopes Júnior, ao analisar o dispositivo legal supracitado, assevera que "chamamos atenção, ainda, para o art. 566, que revela um ranço inquisitório completamente superado, ao estabelecer a 'verdade substancial' ou real, como critério para não reconhecimento da invalidade processual, quando se sabe da absoluta imprestabilidade jurídica e científica deste conceito." (Direito processual penal e sua conformidade constitucional. 6. ed. Rio de Janeiro: Lumen Juris, 2011. v. 2, p. 421).

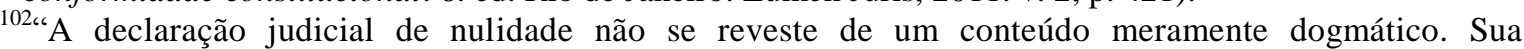
proclamação deve ser executada caso a caso. E não se destina a agasalhar o ato defeituoso que seja irrelevante para o descobrimento da verdade." (BARROS, Marco Antonio de. A busca da verdade no processo penal, cit., p. 323).
} 
Não se pode negar o caráter instrumental do ato processual; a declaração da sua ineficácia deve, de fato, estar condicionada a um dano, ou possibilidade de dano, às partes. No entanto, também não é correto, sob pena de sujeitar o regime de atipicidades processuais a algo apenas utópico e imaginário, vincular a sanatória da instrumentalidade com uma verdade absoluta dos fatos.

Torna-se imprescindível, destarte, para todos os efeitos, desgarrar-se por completo da ideia de verdade real no processo penal. O resultado que se pretende atingir em uma dada apuração criminal não há de estar condicionado, seja na produção das provas, seja na declaração das nulidades, a uma correspondência absoluta à realidade.

\subsubsection{O bem-estar comum e as finalidades coletivas como critérios orientadores do Processo Penal}

Afora o mito da verdade real, outra questão de relevância que se coloca no caminho para identificação da particular instrumentalidade do processo penal diz respeito às finalidades que remetem a bens coletivos. Com efeito, amiúde se verifica em estudos doutrinários, avalizados sem ressalvas pela jurisprudência, o discurso segundo o qual o fim-último do processo, e consequentemente dos atos processuais, seria o de garantir a tranquilidade da sociedade, a paz social ou, ainda, a ordem pública. ${ }^{103}$

De acordo com mencionado posicionamento, a razão de existência do processo penal se confundiria com a própria finalidade do direito material, qual seja, a de promover a paz social. ${ }^{104}$ De evidente gênese no processo de natureza civil, ${ }^{105}$ esses nortes coletivos a serem almejados pelo processo penal estariam todos insertos e contidos dentro de uma

\footnotetext{
${ }^{103}$ Damaska (The faces of justice and state authority. New Haven: Yale University Press, 1986. p. 11) assevera que a finalidade buscada pelo processo penal está diretamente vinculada ao nível de intromissão estatal na administração da justiça: "Where government is conceived as a manager, the administration of justice appears to be devote to fulfillment of state programs and implementation of state policies. In contrast, where government merely maintains the social equilibrium, the administration of justice tends to be associated with conflict resolution."

${ }^{104}$ Tourinho Filho defende que o Direito Processual Penal ostenta duas finalidades. Uma (i) imediata, que seria a de conseguir a "realizabilidade" da pretensão punitiva derivada de um delito, e outra (ii) mediata, que se confundiria com a própria finalidade do Direito Penal, que seria a de promover a paz social. (Processo penal. 31. ed. São Paulo: Saraiva, 2009. v. 1, p. 30).

105،Falar em instrumentalidade do processo, pois, não é falar somente nas suas ligações com a lei material. O Estado é responsável pelo bem-estar da sociedade e dos indivíduos que a compõem: e, estando o bem-estar social turbado pela existência de conflitos entre pessoas, ele se vale do sistema processual para eliminando os conflitos, devolver à sociedade a paz desejada. O processo é uma realidade desse mundo social, legitimada por três ordens de objetivos que através dele e mediante o exercício da jurisdição o Estado persegue: sociais, políticos e jurídico." (CINTRA, Antonio Carlos de Araújo; DINAMARCO, Cândido Rangel; GRINOVER, Ada Pellegrini. Teoria geral do processo, cit., p. 50).
} 
espécie de metaprincípio, denominado interesse público. Os atos processuais, em última análise, estariam a serviço da consecução de fins afetos ao bem da sociedade, tudo em respeito e homenagem ao aludido metaprincípio.

É certo que dificilmente se verá um posicionamento firme no sentido de que ao processo penal caberia somente a tutela de bens supraindividuais, até porque isso constituiria verdadeiro despautério frente à realidade do ordenamento pátrio. No entanto, esses propósitos coletivos encontram-se travestidos, ou por vezes escamoteados, de outros nomes, os quais, no limite, possuem significados idênticos. Não é raro haver aqueles que, para não incorrerem em erro, sustentam ser a distribuição de justiça a função do processo penal. ${ }^{106}$

Por óbvio, não há como negar que o processo penal deva sempre procurar distribuir justiça; deve, sem dúvidas, também buscar o bem-estar da sociedade. Afinal, é próprio do Direito, qualquer que seja seu ramo, solucionar os mais diversos conflitos que surjam na sociedade, e, consequentemente, almejar a paz social, o bem comum. ${ }^{107}$ Essas assertivas, logicamente, não há ninguém que conteste. ${ }^{108}$

O que se coloca como ponto nevrálgico da discussão, contudo, é o fato de que esses nortes coletivos não podem servir de fim-último do processo penal, como se impusessem, sobre todos os atos, uma força centrípeta; tudo, ao final, convergindo a um interesse

\footnotetext{
${ }^{106}$ Hélvio Simões Vidal entende, na esteira do doutrinador Werner Beulke, que haja três funções transcendentes do processo penal caracterizado pela pré-programação do conflito, quais sejam, a averiguação sobre a existência de uma pretensão legítima, a prolação de uma decisão conforme ao processo e a realização de justiça, sendo impensável um processo penal que se inicie e termine sem possuir a função de distribuir justiça. (VIDAL, Hélvio Simões. Curso avançado de processo penal. Belo Horizonte: Arraes, 2011).

${ }^{107}$ Asseverava Miguel Reale: "a Justiça que, como se vê, não é senão a expressão unitária e integrante dos valores todos de convivência, pressupõe o valor transcendental da pessoa humana, e representa, por sua vez, o pressuposto de toda a ordem jurídica. Essa compreensão histórico-social da Justiça leva-nos a identificá-la com o bem comum, dando, porém, a este termo sentido diverso do que lhe conferem os que atentam mais para os elementos de 'estrutura', de forma abstrata e estática, sem reconhecerem que o bem comum só pode ser concebido, concretamente, como um processo incessante de composição de valorações e de interesses, tendo como base ou fulcro o valor condicionante da liberdade espiritual, a pessoa como fonte constitutiva da experiência ético-jurídica." (Filosofia do direito. 18. ed. São Paulo: Saraiva, 1998. p. 272).

${ }^{108}$ Eugenio Pacelli, ao se manifestar sobre os escopos metajurídicos [Dinamarco] do processo, tais como missão social e política do exercício do poder jurisdicional, explica: "Embora nos posicionemos inteiramente de acordo com uma concepção não formalista do processo, pensamos que essa é uma questão que transcende ao exame específico de qualquer disciplina jurídica. Não só o direito deve ser interpretado e aplicado segundo finalidades sociais (pacificação com justiça, educação), políticas (liberdade, participação, afirmação da autoridade do Estado e do seu ordenamento). Esse é uma missão do Direito em sua totalidade." (Processo e hermenêutica na tutela penal dos direitos fundamentais. 2. ed. Rio de Janeiro: Lumen Juris, 2009. p.24).
} 
coletivo da sociedade. ${ }^{109}$ É dizer: o instrumento-processo não deve ser visto como mecanismo imbuído de um propósito único, exclusivo, de promover o bem-estar social. ${ }^{110}$

Cumpre observar que esses ideais supraindividuais - ainda que disfarçados e distorcidos - aparecem nas mais variadas situações ao longo da persecução criminal. São os meios utilizados, não raras vezes, por magistrados para motivar decisões judiciais, notadamente quando inexistentes fundamentos suficientes que possam ser extraídos diretamente do texto normativo. ${ }^{111}$

Essa tendência se verifica provavelmente com maior clareza - e de forma mais escancarada - em casos envolvendo a imposição de medidas cautelares pessoais. Ao se analisar o cabimento da custódia do indivíduo no decorrer do persecutio criminis, muitas vezes não são analisados os requisitos de cautelaridade, próprios daquela medida, mas, sim, sob o aberto e indeterminado requisito da garantia da ordem pública, se a liberdade do indivíduo pode incomodar a paz social, ${ }^{112}$ a credibilidade da justiça, ${ }^{113}$ bem como o clamor

\footnotetext{
${ }^{109} \mathrm{~A}$ forma como a vagueza desse conceitos tem afetado a legitimidade de uma decisão judicial não passou despercebida por Nicklas Luhmann (Legitimação pelo procedimento, cit., p. 21) que adverte: “ou então [os juízes] tem de recorrer a fórmulas duplas, contraditórias, como proteção jurídica, paz jurídica, que oculta decisões justas e injustas."

${ }^{110}$ Salo de Carvalho relaciona os fins comuns do processo às ideias punitivistas extremadas: "Note-se que se encontra em frontal oposição às propostas de Defesa Social. Nestas, o sistema é dirigido para o resguardo da sociedade, sacrificando o infrator em prol do bem-comum; naquela [proposta garantista], o objeto de garantia são os direitos fundamentais do cidadão contra os anseios de vingança (pública ou privada; individual ou coletiva)". CARVALHO, Salo de. Pena e garantias. 3. ed. Rio de Janeiro: Lumen Juris, 2008. p. 95.

${ }^{111}$ Lenio Streck(Verdade e consenso. 4. ed. São Paulo: Saraiva, 2012. p. 48) chama a atenção para a Jurisprudência de Valores, que teria servido para possibilitar, no pós-guerra alemão de 1949, que juízes pudessem valer-se de critérios outros, que não a lei, para fundamentar suas decisões. Tais valores serviriam como um mecanismo de 'abertura' em meio a uma legalidade hermética. A despeito de o autor mencionar que, nos dias atuais, os operadores do direito estão utilizando tal teoria para extrair valores da Constituição Federal, pensamos que também seria adequado, na espécie, uma Jurisprudência de Valores Coletivos.

112،Prisão preventiva. Materialidade e indícios de autoria. Réu perigoso. Paz social abalada. Coação ilegal inexistente. Constado que a prisão preventiva do paciente está fundamentada na sua confissão na polícia, onde contou, detalhadamente, a sua participação no evento delituoso e que o decreto levou em conta ser o réu uma pessoa perigosa com indiciamento em vários outros delitos que atormentam a sociedade, tem-se como preenchido um dos requisitos do art. 312 do CPP. Prisão legal. Ordem denegada." (TJMA - HC 1294220/04 - j. 19.8.2004).

113،Habeas corpus. Receptação. Prisão preventiva. Necessidade de manutenção da ordem pública. Denegada a Ordem. Cabe a custódia cautelar para manter a ordem pública, a fim de acautelar o meio social e a própria credibilidade da justiça. (TJSP - HC 990.08.126472-2 - 4ª Câmara Criminal - j. 3.2.2009).
} 
público, ${ }^{114}$ como se esses bens ou interesses constituíssem a genuína finalidade pretendida pela lei processual. ${ }^{115}$

Muito embora se possa argumentar que esses fundamentos apenas se limitam à imposição da constrição cautelar do indivíduo, não guardando relação alguma com a finalidade do processo, há de se entender que uma coisa não pode ser separada da outra. Quando se permite dizer que o intento-reitor do processo é a preservação da paz social, ou o bem-estar comum, não deve vir como surpresa para ninguém que o magistrado possa prestar homenagem a esse propósito ao longo da instrução criminal também.

Outrossim, se é possível dar ao processo uma finalidade supraindividual, justificase outro discurso, também já tão arraigado em nosso meio jurídico, e igualmente pernicioso, o da prevalência do direito público sobre as garantias do acusado. ${ }^{116}$ De fato, quando se coloca como centro do processo tais bens coletivos, tornando-os verdadeiros horizontes a serem alcançados, tudo se justifica em nome de um interesse público. ${ }^{117}$

Insta notar que se tem tornado cada vez mais recorrente a flexibilização de direitos fundamentais em nome de um suposto interesse público (afinal, qual seria ele?). ${ }^{118}$ Tamanha é a obsessão de alguns com a supremacia de um direito coletivo em relação às garantias individuais que já não é mais novidade falar-se em incidência do princípio da

\footnotetext{
${ }^{114}$ Aliás, quanto à invocação do clamor público para fundamentar a prisão preventiva, Odone Sanguiné, adverte que "seria errôneo considerar que a prisão possa cumprir o fim de dar satisfação ao público sentimento de justiça, ante o qual é suficiente processar penalmente o imputado. Na prática, todavia, a autoridade judicial se inspira nesses falsos critérios, como se a justiça fosse servidora da política, ou, pior, da demagogia." (A inconstitucionalidade do clamor público como fundamento da prisão preventiva. Boletim IBCCRIM, São Paulo, p. 29-31, out. 2001).

${ }^{115}$ Essa fundamentação baseada em bens coletivos e indeterminada para imposição de prisões não passou despercebida por Gustavo Badaró, para quem "a expressão 'ordem pública' é vaga e de conteúdo indeterminado. A ausência de um referencial semântico seguro para a 'garantia da ordem pública' coloca em risco a liberdade individual. A jurisprudência tem se valido das mais diversas situações reconduzíveis à garantia da ordem pública: 'comoção social', 'periculosidade do réu', 'perversão do crime', 'insensibilidade moral do acusado', 'credibilidade da justiça', 'clamor público', 'repercussão na mídia', 'preservação da integridade física do indiciado'... Tudo cabe na prisão para garantia da ordem pública." (Processo penal, cit., p. 733).

${ }^{116} \mathrm{~A}$ demonstrar, apenas como exemplo, o atual pensamento da jurisprudência em relação a essa prevalência do público sobre o privado, cite-se trecho de acórdão proferido pelo Superior Tribunal de Justiça: "Somente sob a visão estritamente individualista e rigorosamente clássica do Processo Penal, se poderá afirmar que esses macro-valores devam ser subjugados a interesses individuais, eis que se trata de elementos axiológicos estruturantes da própria vida social, a que o Direito tem que dar efetividade." (HC 106.742-SP $-5^{\mathrm{a}}$ Turma - rel. Min. Napoleão Nunes Maia Filho - j. 27.5.2008, p. 23.6.2008).

${ }^{117}$ Essa intenção de se entender bem comum como de interesse público já foi objeto de estudo de Humberto Ávila, o qual ressaltou ser o bem comum a própria composição harmônica do bem de cada um com o de todos, não o direcionamento dessa composição em favor do interesse público. (Repensando o princípio da supremacia do interesse público. Revista Trimestral de Direito Público, São Paulo, n. 24, p. 160, 1998).

118“"Aí está a nota essencial do Estado Novo e do Código: a primazia do interesse do Estado sobre o interesse do cidadão. Como se não fosse o Estado o meio para a consecução do bem comum, qual seja, a concretização do bem estar e das potencialidades dos cidadãos." (CARVALHO, Luis Gustavo Grandinetti Castanho de. Processo penal e Constituição. 5. ed. Rio de Janeiro: Lumen Juris, 2009. p. 1).
} 
proporcionalidade em matéria de prova ilícita. Em homenagem a um interesse público, poder-se-ia utilizar, em desfavor do réu, provas inadmitidas no ordenamento penal. ${ }^{119}$ Levando-se ao extremo, e a continuar nessa forma de raciocínio, não causará estranheza se, amanhã ou depois, a pretexto de buscar a paz social, houver condescendência - em claro retorno a tempos nada saudosos - em torturar o acusado para obtenção de informações eventualmente úteis à sociedade. ${ }^{120}$

Essa dicotomia interesse público $\mathrm{X}$ interesse privado, no processo penal, também se manifestará no estudo das nulidades. A posição hodierna adotada de forma quase unânime pela doutrina, referendada sem restrições por nossas Cortes, é a de que somente se reconhecerá a nulidade absoluta quando o vício atingir o interesse público. Do contrário, ou seja, caso inexista afetação do interesse público, há apenas nulidade relativa, a qual, para ser decretada, exigirá a comprovação do prejuízo. ${ }^{121}$ Os interesses do réu, também para fins de nulidade, ficam relegados a um segundo plano.

Verifica-se, portanto, que essa visão de supremacia do interesse da coletividade ganha cada vez mais corpo no direito processual penal, sendo certo que sua incidência, mesmo que sob diferentes nomenclaturas ("bem comum", "paz social”, etc.), se alastra pelos mais diversos campos dessa ciência. ${ }^{122}$

Conforme se verá adiante, no entanto, o processo penal, se democrático pretende ser, precisa centrar-se no acusado ${ }^{123}$. É por isso que LOPES JR acentua, com acerto, que o

\footnotetext{
${ }^{119}$ Nesse sentido, por todos, há de se citar a posição de Eugenio Pacelli: “A Suprema Corte deveria estar um pouco mais atenta no que respeita à possibilidade, sempre excepcional é certo, da aplicação do princípio da proporcionalidade em temas de provas ilícitas, no que, aliás, nem de longe, seria pioneira. (...) Como veremos adiante, em determinadas circunstâncias (e uma delas é a previsão em lei), serão possíveis algumas intervenções corporais na produção da prova, mesmo quando em desfavor do réu." (Curso de processo penal. 15. ed. Rio de Janeiro: Lumen Juris, 2011. p. 380-381).

${ }^{120} \mathrm{~A}$ jurisprudência, ainda que de forma muito tímida, vem chancelando o entendimento doutrinário do aproveitamento da prova ilícita pro societate, seja para aceitar a intervenção corporal contra a vontade do indivíduo (STF - RCL 2.040/DF, Pleno, j. 21.2.2002), seja para permitir a mitigação da garantia do sigilo da intimidade (RSTJ n. 109/269; RJDTACrim n. 39/550). Sobre o tema da possibilidade da prática da tortura em casos extremamente excepcionais, nos quais uma informação do torturado poderá salvar vidas, cf. GRECO, Luis. As regras por trás da exceção: reflexões sobre a tortura nos chamados "casos de bombarelógio". Revista Brasileira de Ciências Criminais, São Paulo, v. 17, n. 78, p. 7-40, maio/jun. 2009.

${ }^{121}$ A divisão entre nulidade absoluta e nulidade relativa será objeto de estudo específico mais adiante. Por ora, por todos, cf. GRINOVER, Ada Pellegrini; FERNANDES, Antonio Scarance; GOMES FILHO, Antonio Magalhães. As nulidades no processo penal, cit., p. 20-21.

${ }^{122} \mathrm{De}$ acordo com Gloeckner, é de se rechaçar, por completo, justificativas que conduzam o processo penal rumo ao escopo de se atingir finalidades coletivas, públicas ou mesmo éticas. (Nulidades no processo penal: introdução principiológica à teoria do ato processual irregular, cit., p. 46).

${ }^{123}$ Contribui para essa visão a ideia de Ferrajoli, de que o processo penal és la ley del más débil. No momento da prática do delito, a vítima é a parte hipossuficiente, sendo certo que ao longo do processo penal tal modelo se inverte, passando o acusado a ser a parte débil. (Derechos y garantias: la ley del más débil. Trad. Perfecto Andrés Ibáñez e Andrea Greppi. 3. ed. Madrid: Trotta, 1999).
} 
"Estado só se justifica enquanto meio que tem como fim a tutela do homem e dos seus direitos fundamentais, porque busca o bem comum, que nada mais é do que o benefício de todos e de cada um dos indivíduos. " 24 Nessa esteira de pensamento, e por via de consequência, o mesmo autor, ao analisar a dicotomia entre interesses privados e públicos, considera ser "uma manipulação discursiva que faz um maniqueísmo grosseiro (senão interesseiro) para legitimar e pretender justificar o abuso de poder. "125

Frise-se, para que não haja equivocadas interpretações: aqui não se sustenta a renúncia completa de interesses coletivos no processo penal. Nem se poderia. ${ }^{126}$ Como parcela, ainda que pequena, de um sistema organizacional da sociedade, cabe ao processo penal também o dever de zelar por justiça, bem como o de promover a tranquilidade social.

No entanto, o processo penal não se legitima a partir da consecução de direitos coletivos. $\mathrm{O}$ bem-estar comum, desta feita, não deve ser sua finalidade precípua, sob pena de se deturpar a instrumentalidade pretendida pela Constituição Federal de 1988, possibilitando que argumentos fundados na supremacia dos interesses públicos justifiquem, no mais das vezes, o desrespeito aos direitos fundamentais.

\subsection{A Instrumentalidade Constitucional do Processo: identificação da forma como guardiã das garantias individuais}

\subsubsection{Processo: escudo do acusado contra arbitrariedades}

Superadas as questões tendentes a desviar o foco sobre a compreensão da real função desempenhada pelo processo penal, chega o momento de se destacar a sua particular instrumentalidade frente ao ordenamento jurídico. Que o processo penal constitui um instrumento indispensável para aplicação de uma pena, disso não há dúvida. No entanto, é do conteúdo desse caminho, das pegadas deixadas por essa trilha, que se revelará o papel do processo penal moderno.

\footnotetext{
${ }^{124}$ LOPES JÚNIOR, Aury. Direito processual penal e sua conformidade constitucional, cit., v. 1, p. 14.

${ }^{125}$ LOPES JÚNIOR, Aury. Direito processual penal e sua conformidade constitucional, cit., v. 1, p. 11.

${ }^{126}$ Figueiredo Dias afirma que cada cidadão tem um interesse na correta e impoluta administração da justiça penal (interesse da comunidade) que se converge com o interesse do próprio acusado, o que não significa que esses dois interesses corram sempre paralelos. (DIAS, José de Figueiredo. Direito processual penal, cit., v. 1, p. 223).
} 
É certo que a imposição de uma sanção penal não prescinde de um devido processo legal. Por outro lado, também parece correto afirmar que a satisfação de uma pretensão acusatória não constitui o fim-último do processo; ${ }^{127}$ antes, ele surge justamente como anteparo para que ela seja chancelada.

Como é cediço, a punição estatal, ainda que institucionalizada, se relaciona umbilicalmente com a figura do poder. O poder, à evidência, não aceita vácuo; tende a extravasar, usurpar as barreiras contra si impostas, até que encontre um freio à altura que forçosamente o faça desacelerar. ${ }^{128}$ Tratar de poder, necessariamente significa delinear limites, ${ }^{129}$ pois a sua ausência acarretará a existência de modelos autoritários. ${ }^{130}$

Com efeito, considerando que a sociedade ainda não conseguiu enfrentar determinados tipos de perturbação do convívio a não ser pela supressão da liberdade do agente, ${ }^{131}$ o Estado outorgou para si, como forma de contenção da criminalidade, a exclusividade do poder de punir. ${ }^{132}$ Todavia, referido poder, para que legítimo seja, deve contar com freios adequados e ser corretamente delimitado, sob pena de se operar, ao invés de justiça, vingança arbitrária. ${ }^{133}$

O processo penal, assim, se projeta como mecanismo de constrição desse poder de punir. ${ }^{134}$ É dele o papel de criar genuíno filtro entre dois poderes que emanam diretamente

${ }^{127}$ LOPES JÚNIOR, Aury. Direito processual penal e sua conformidade constitucional, cit., v. 1, p. 26.

${ }^{128}$ GLOECKNER, Ricardo Jacobsen. Nulidades no processo penal: introdução principiológica à teoria do ato processual irregular, cit., p. 29. O autor também lembra que a transgressão é outro símbolo da ilimitação.

${ }^{129}$ Não por acaso, Montesquieu, percebendo o prejuízo do extravasamento do poder, afirmou ser necessário que o poder limite o poder, condicionando a base para a sua mais célebre construção teórica da separação dos poderes.

${ }^{130}$ Eberhard Schmidt (Los fundamentos teóricos y constitucionales del derecho procesal penal. Tradução José Nuñez. Buenos Aires: Lerner, 2006) adverte que todo poder envolve a possibilidade de excessos e de abusos.

${ }^{131}$ MALHEIROS FILHO, Arnaldo. Direito penal econômico e crimes de mero capricho. In: VILARDI, Celso; PEREIRA, Flavia Rahal Bresser; DIAS NETO, Theodomiro (Coords.). Direito penal econômico. São Paulo: Saraiva, 2009. p. 65. O autor complementa o raciocínio dizendo que "os resultados [das prisões] têm sido péssimos, não só pelo elevado custo humano, social e econômico do sistema, não só pela desnaturação da condição humana através do enjaulamento, mas sobretudo pelo retumbante fracasso da 'terapia', especialmente se medido pelas taxas de reincidência."

${ }^{132}$ Parece ser por essa razão que Salo de Carvalho pondera que o monopólio estatal na função punitiva desponta justamente como instrumento contra a beligerância, fazendo com que os contratantes abdiquem da vingança privada. (Pena e garantias, cit., p. 93).

${ }^{133 ،} Y$ en el positivismo jurídico, si por un lado está en la base del principio de estricta legalidad, por el otro también permite modelos penales absolutistas caracterizados por la ausencia de límites al poder normativo del soberano, al igual que es en caso por completo natural respecto de todas las demás garantías penales y procesales." (FERRAJOLI, Luigi. Derecho y razón, cit., p. 33).

${ }^{134}$ "Do ponto de vista das liberdades clássicas, a liberdade do indivíduo coloca-se como limite à atividade estatal, que não pode invadir a esfera de autodeterminação do homem, senão observando determinadas regras postas pelo princípio da legalidade.” GRINOVER, Ada Pellegrini. Liberdades públicas e processo penal, cit., p. 15. 
do Estado, quais sejam, a pretensão acusatória e a imposição de uma sanção criminal. ${ }^{135}$ Justamente por essa razão é que não se pode ver com bons olhos propostas de um processo penal voltado exclusivamente à celeridade e eficiência, sem levar em conta seu caráter protetivo.

Diante desse cenário, o processo penal, restringindo o poder do Estado, deve funcionar primordialmente como um instrumento de proteção do acusado. ${ }^{136}$ Conforme observa GRINOVER, lembrando os ensinamentos de Giussepe Bettiol, o surgimento do processo penal deve ser concebido como consequência do aparecimento do Estado de direito, ideia de garantia para as liberdades do cidadão e de limitação da intervenção estatal. ${ }^{137}$

Se é verdade que o processo penal é um pressuposto para aplicação de uma sanção penal, também não se deve negar que sua função essencial é a de proteção do acusado. ${ }^{138}$ Cabe ao processo penal, em seu caráter teleológico, a criação de condições para garantir ao indivíduo meios para enfrentar eventuais - e sempre possíveis - abusos da força estatal repressora. ${ }^{139}$

Assume o acusado, portanto, a condição de parte débil [Ferrajoli] na relação processual penal. ${ }^{140}$ Quando comparado ao poderio estatal, de fato deve-se colocar o indivíduo na posição de hipossuficiente, sendo necessário franquear a ele mecanismos efetivos para que ele possa provar sua eventual inocência ${ }^{141}$. De se dizer que essa debilidade do réu, diferentemente do que ocorre em outras áreas do Direito, em nada se

\footnotetext{
${ }^{135}$ De se lembrar, nesse ponto, a indagação de GOLDSCHMIDT: "se o Estado, tendo o poder de punir, tendo ele, inclusive, domínio soberano sobre todos os seus súditos, por qual motivo necessitaria provar seu direito em um processo?"

${ }^{136}$ Registre-se, por contrário, a posição de Manzini, para quem o interesse a ser tutelado no processo penal é a pretensão punitiva: "La pseudo democracia de tipo francés, superficial, gárrula y confucionista en todo, ha cometido también el desacierto de enturbiar los conceptos, afirmando que la finalidad del proceso penal es principalmente la de tutelar la inocencia, o que ella se asocia a la de la represión de la delincuencia (finalidades jurídicas), agregando también la intención (finalidad política) de dar al Pueblo la garantía de la exclusión del error y de la arbitrariedad." (Tratado de derecho procesal penal. Tradução Santiago Sentís Melendo y Marino Ayerra Redín. Buenos Aires: El Foro, 1996. t. 1, p. 252).

${ }^{137}$ GRINOVER, Ada Pellegrini. Liberdades públicas e processo penal, cit., p. 16. Nessa mesma linha, Aragoneses Alonso assevera que "tiene el Estado el deber de proteger al propio delincuente, pues esto también es una forma de garantizar el libre desarrollo de la personalidad, que es la función de la justicia." (Instituiciones de derecho procesal penal. 5. ed. Madrid: Rubi Artes Gráficas, 1984. p. 7).

${ }^{138}$ CARRARA, Francesco. Il diritto penale e la procedura penale, cit., v. 5, p. 10.

${ }^{139}$ PACELLI, Eugenio. Processo e hermenêutica na tutela penal dos direitos fundamentais, cit., p. 22.

${ }^{140 ،}$ “El fin del derecho penal no es reducible a la mera defensa social de los intereses constituidos contra la amenaza representada por los delitos. Es, más bien, la protección del débil contra el más fuerte: del débil ofendido o amenazado por el delito, así como del débil ofendido o amenazado por la venganza; contra el más fuerte, que en el delito es el delincuente y en la venganza es la parte ofendida o los sujetos públicos o privados solidarios con el." (FERRAJOLI, Luigi. Derecho y razón, cit., p. 335).

${ }^{141 \text { ' } D a ~ n e g a c ̧ a ̃ o ~ d o ~ e s t a d o ~ s e l v a g e m ~ b a s e a d o ~ n a ~ p a s s i o n a l i d a d e, ~ o ~ d i r e i t o ~(p e n a l) ~ c o n f i g u r a r i a ~ u m a ~ r a z a ̃ o ~}$ artificial de tutela do débil contra os desejos de represália. Do exposto, tem-se a justificativa do modelo garantista: o direito penal e processual penal legitimam-se como lei de tutela do mais fraco". CARVALHO, Salo de. Pena e garantias, cit., p. 95.
} 
relaciona com a sua condição econômica ou sociopolítica, senão que decorre do lugar em que é obrigado a ocupar no ritual judiciário. ${ }^{142}$

Ressalte-se, contudo, que a mera assunção de que o acusado constitui o lado mais fraco do jogo processual afigura-se, por si só, insuficiente para explicar o específico conteúdo instrumental do processo penal. Na realidade, tal entendimento serve apenas de pressuposto para compreender a necessária e inescapável ligação entre processo e Constituição. ${ }^{143}$

Cumpre lembrar que, desde sua gênese, a ideia de se elaborarem constituições escritas está intimamente relacionada com o estabelecimento de limites ao poder político. ${ }^{144}$ Ao assegurar direitos fundamentais aos cidadãos, segundo CANOTILHO, a Carta Política está na realidade garantindo direitos de defesa, que atuam sob uma dupla perspectiva: (i) constituem, num plano jurídico-objetivo, normas de competência negativa para os poderes políticos, proibindo fundamentalmente as ingerências destes na esfera individual, e (ii) implicam, num plano jurídico-subjetivo, o poder de exercer positivamente direitos fundamentais e de exigir omissões dos poderes públicos, de forma a evitar agressões lesivas por parte dos mesmos ${ }^{145}$.

É de fato no texto constitucional que o réu encontrará amparo - suas verdadeiras armas - para equalizar sua situação deficitária processual. ${ }^{146}$ Não é senão no conteúdo da Constituição Federal que se verá com maior nitidez os reflexos de uma opção por um processo centrado no indivíduo, ${ }^{147}$ concedendo a ele garantias inegociáveis, as quais devem ser obrigatoriamente respeitadas no decorrer da persecutio criminis. ${ }^{148}$

\footnotetext{
${ }^{142}$ LOPES JÚNIOR, Aury. Direito processual penal e sua conformidade constitucional, cit., v. 1, p. 29.

${ }^{143 ،} \mathrm{O}$ importante não é apenas realçar que as garantias do acusado - que são, repita-se, garantias do processo e da jurisdição - foram alçadas a nível constitucional, pairando sobre a lei ordinária à qual informam. É verificar a adequação das leis à letra a ao espírito da Constituição." GRINOVER. Ada Pellegrini. As garantias constitucionais no processo. In: GRINOVER. Ada Pellegrini. Novas tendências do direito processual de acordo com a Constituição de 1988. São Paulo: Forense Universitária, 1990. p. 14.

${ }^{144}$ Não custa lembrar aqui, apenas a título ilustrativo, a Magna Carta de 1215, a qual, já naquela época, foi assinada com intuito precípuo de limitar os poderes dos monarcas da Inglaterra, evitando o exercício do absolutismo.

${ }^{145}$ Apud. MORAES, Alexandre de. Direito constitucional. 23. ed. São Paulo: Atlas, 2008. p. 30.

${ }^{146}$ “En realidad, todos los principios limitadores del poder penal del Estado que contiene la Constitución nacional son desarrollados y reglamentados en los códigos de procedimientos penales y leyes orgánicas judiciales. Al menos, así debe ser, por la supremacía constitucional, que determina la vigencia de la ley. Desde este punto de vista, el Derecho procesal penal es un estatuto de garantías, sobre todo para quien es perseguido penalmente, garantías que, incluso, se supraordinan a las demás funciones que también se le adjudica." MAIER, Julio. Derecho procesal penal. Editores del Puerto: Buenos Aires, 2004. p. 91.

${ }^{147}$ CARVALHO, Salo de. Pena e garantias, cit., p. 93.

148، O respeito pelos direitos fundamentais das pessoas, que por isso se deve considerar também como um fim do processo, conduz, por exemplo, a considerar inadmissíveis certos métodos de obtenção de prova e a cominar a nulidade das que tenham sido alcançadas mediante tortura, coacção ou, em geral, ofensa da integridade física ou moral das pessoas." SILVA, Germano Marques da. Curso de processo penal. Lisboa: Editorial Verbo, 1994. t. 1, p. 25.
} 
Já de há muito, a Constituição Federal não pode ser mais considerada somente um documento, ${ }^{149}$ uma carta de intenções, ${ }^{150}$ em cujas linhas se verificariam apenas princípios programáticos. ${ }^{151}$ Ao revés, a Constituição passa a integrar, ela própria, ao determinar a validade da legislação infraconstitucional, o ordenamento processual, sendo certo que o modelo de processo vigente deve se conformar com ela e se constituir a partir dela. ${ }^{152}$

Não é suficiente que a Constituição seja elevada a um status superior. ${ }^{153}$ Ela não há de servir, outrossim, de ideal ou horizonte, como se a permitir que o legislador ou intérprete apenas a observem à distância. Os direitos fundamentais criam, em verdade, a base do caminho pelo qual necessariamente o Estado precisa trilhar para aplicação de uma sanção penal.

Conforme o pensamento de BINDER, a Constituição forma espécie de escudo protetor da dignidade humana. É imperioso, segundo o jurista argentino, que se dê efetividade aos direitos e garantias insculpidos na Carta Política, pois o respeito a essas salvaguardas jurídicas - e, consequentemente, à dignidade humana - é o que diferencia o Direito das ordens próprias de governos despóticos. ${ }^{154}$

É imperativo que o processo penal brasileiro não seja mais interpretado somente à luz de um Código ultrapassado, de notórias influências fascistas (1941), ${ }^{155}$ no corpo do

\footnotetext{
${ }^{149}$ É de se refutar a tese do alemão Carl Schmitt, para quem, ainda que existisse uma Constituição, o acusado não detinha garantia alguma, sendo sempre possível ao Führer impor suas vontades em detrimento dos "inimigos do Estado".

${ }^{150} \mathrm{Na}$ feliz expressão de Canotilho, o texto constitucional deixa de ser uma "bíblia de promessas". ("Brancosos" e interconstitucionalidade: itinerários dos discursos sobre a historicidade constitucional. Coimbra: Almedina, 2009. p. 31).

${ }^{151}$ FERNANDES, Antonio Scarance. Processo penal constitucional, cit., p. 27.

152،"Mas, de nada valeria - acrescentamos - a projeção do ideal de definir os direitos do homem, notoriamente uma das mais importantes conquistas do século XVII, se a respectiva declaração não se fizesse prover de meios hábeis à sua realização por um dos poderes do Estado, autônomo e independente dos demais: vale dizer, se não se vissem eles garantidos por instrumentos aptos à sua asseguração, ao seu reconhecimento, ou à sua satisfação por órgãos estatais aos quais conferidos poderes para sua precaução, determinação ou efetivação." TUCCI, Rogerio Lauria. Direitos e garantias individuais no processo penal brasileiro. 3. ed. São Paulo: Ed. Revista dos Tribunais, 2009. p. 50.

${ }^{153}$ GLOECKNER, Ricardo Jacobsen. Nulidades no processo penal: introdução principiológica à teoria do ato processual irregular, cit., p. 36.

${ }^{154}$ BINDER, Alberto. Introdução ao direito processual penal. Trad. Fernando Zani. Rio de Janeiro: Lumen Juris, 2003. p. 38-43. Ferrajoli lembra que o processo se distingue de um modelo de justiça pelas próprias mãos, e de outros métodos bárbaros de justiça pelo fato de que persegue, além da punição dos culpados, a tutela dos inocentes.

${ }^{155}$ Sobre a influência do fascismo, inclusive no tema das nulidades insertas no Código Rocco italiano (1930), o qual, por sua vez, inspirou o CPP brasileiro vigente, Gabriella Di Paolo ensina que "naturale che algi ideali autoritari dello Stato fascista, prima, e all'assetto valoriale della Costituzione Repubblicana, poi, abbiano corriposto uma diversa concezione della funzione delle forme e um diverso approccio al problema dei vizi degli atti processuali, dei quali può ravvisarsi chiara riprova, rispettivamente, nel regime delle nullità appronatao dal legislatore del '30 e negli interventi riformatori delgi anni Cinquanta e Settanta." (DI PAOLO, Gabriella. La sanatoria delle nullità nel processo penale. Milano: Cedam, 2012. p. 62-63).
} 
qual se espraiam inúmeros dispositivos não consentâneos com a realidade jurídica atual. ${ }^{156}$ A estrita observância às garantias fundamentais, conquistadas a duras penas em nosso país, é que garantirá um processo penal justo.

Consoante adverte Giacomolli, "as regras do processo penal e os sujeitos do processo, em um Estado Democrático, se subordinam à ordem constitucional vigente. No caso brasileiro, a estrutura do processo penal (CPP da década de 1940) se assenta em bases essencialmente autoritárias, inquisitoriais, centradas em uma ordem assimétrica, monopolizadora e piramidal (supremacia do juiz), burocratizada hierarquicamente, de tradição autoritária (ditadura Vargas), sem espaço à metodologia dialética, motivo por que se faz necessário ir além do ôntico (superficialidade)."

É por esse motivo que parece correto falar, hoje em dia, em uma instrumentalidade constitucional do processo penal. O instrumento-processo se legitimará somente quando e se - for constituído a partir da Constituição. ${ }^{158}$ Cabe ao processo, por conseguinte, permitir a menor incidência - diminuição do espaço - do extravasamento do poder Estatal, e apenas poderá cumprir esse desiderato na medida em que conferir máxima eficácia aos direitos fundamentais do acusado.

Saliente-se que ao se propor uma instrumentalidade constitucional ao processo penal não se está pretendendo impor uma visão absoluta das liberdades individuais. Por óbvio, como não poderia deixar de ocorrer em um ramo que lida diretamente com a criminalidade, o processo penal deve dispor de meios que possibilitem efetivamente que o Estado comprove a sua pretensão acusatória inicial. Impedir que o Estado possa lançar mão de medidas restritivas de direitos fundamentais, tais como interceptações telefônicas ou prisões cautelares, impossibilitaria uma efetiva persecução de condutas potencialmente criminosas.

Porém, se é a proteção ao hipossuficiente o fim-último que se pretende, não há outra saída que não a da estreita vinculação entre processo e Constituição. O poder acusatório - que, como outro qualquer, sempre tende a transpor as barreiras impostas somente poderá ser contido se atuar conforme as determinações (normas) da Constituição, uma vez que, novamente recorrendo ao escólio de GRINOVER, “a lei do processo é o

\footnotetext{
${ }^{156}$ CARVALHO, Luis Gustavo Grandinetti Castanho de. Processo penal e Constituição, cit., p. 3.

${ }^{157}$ GIACOMOLLI, Nereu. O devido processo penal, cit., p. 84.

${ }^{158}$ LOPES JÚNIOR, Aury. Direito processual penal e sua conformidade constitucional, cit., v. 1, p. 28.
} 
prolongamento e a efetivação do capítulo constitucional sobre os direitos fundamentais e suas garantias." 159

\subsubsection{A forma como guardiã das garantias fundamentais}

No item anterior, buscou-se desenvolver a ideia da instrumentalidade do processo penal lastreada na concepção de limitação do poder de punir. A aplicação de uma sanção penal não depende apenas da existência do processo; ela (pena) se legitima apenas e tão somente a partir do momento em que o processo estiver estreitamente vinculado aos preceitos constitucionais, mormente os direitos e garantias fundamentais. ${ }^{160}$

Contudo, para que o processo possa cumprir seu mister, obrigatoriamente deve ser ele estruturado de maneira a permitir uma apuração de seu objeto consentânea com a instrumentalidade pretendida. Essa função garantidora contra a arbitrariedade - própria do processo penal - deve estar refletida, respectivamente, na elaboração do rito a ser seguido durante o processo, nos atos que formam tal rito, e, por via de consequência, nas formas mantidas por esses atos.

Com propriedade, já em 1901 JOÃo MENDES advertia que "as leis do processo são o complemento necessário das leis constitucionaes; as formalidades do processo são as actualidades das garantias constitucionaes. Si o modo e a forma da realização dessas garantias fossem deixados ao critério das partes ou à discrição dos juízes, a justiça, marchando sem guia, mesmo sob o mais prudente dos arbítrios, seria uma occasião constante de desconfianças e surpresas." $" 161$

A forma representaria, por assim dizer, a menor unidade funcional do processo. Seria ela o revestimento, a veste externa, dos atos processuais ${ }^{162}$. Em última instância, seguindo as lições de COUTURE, o direito processual nada mais é que um conjunto de formas prefixadas pela ordem jurídica ${ }^{163}$.

\footnotetext{
${ }^{159}$ GRINOVER, Ada Pellegrini. Liberdades públicas e processo penal, cit., p. 21.

${ }^{160}$ GLOECKNER, Ricardo Jacobsen. Nulidades no processo penal: introdução principiológica à teoria do ato processual irregular, cit., p. 430-431.

${ }^{161}$ MENDES JÚNIOR, João. O processo criminal brazileiro. Rio de Janeiro: Laemmert \& Cia, 1901. v. 1, p. 5.

${ }^{162}$ KOMATSU, Roque. Da invalidade no processo civil. São Paulo: Ed. Revista dos Tribunais, 1991. p. 130.

${ }^{163}$ COUTURE, Eduardo J. Fundamentos del derecho procesal civil. 4. ed. Buenos Aires: Euros, 2002. p. 304305. Nas lições de Borges da Rosa, "a forma de uma coisa é a configuração exterior dessa coisa; é o conjunto das qualidades, propriedades ou modalidades pelas quais uma coisa esse ato se manifesta, se revela aos nossos sentidos. A forma de um ato, no terreno jurídico, é, pois, a manifestação exterior desse ato; é o conjunto das modalidades pelas quais esse ato se manifesta. Diz-se que um ato tem forma legal quanto contém as formalidades, as modalidades exigidas pela Lei." (Comentários ao Código de Processo Penal, cit., p. 632).
} 
É verdade que o conceito de forma não está limitado apenas ao estudo do Direito. Porém, é provavelmente no campo do processo penal que ele ganha maior relevo. ${ }^{164} \mathrm{O}$ desenho do ato processual penal tem uma razão de existir. Apenas a título exemplificativo, a citação do réu, com todas as suas características, ostenta forma própria no âmbito do processo penal. Essa roupagem particular, cujos contornos estão descritos por lei, mantém uma racionalidade, a qual deve estar em sintonia com o funcionamento do processo.

Não se pode compreender a teoria das nulidades, e as eventuais causas de convalidação dos atos processuais, sem que se lancem luzes sobre o papel das formas. $\mathrm{O}$ grau de instrumentalidade de um ato processual praticado somente pode ser medido a partir do momento em que se descortinem as razões de existência da forma no processo penal. Até porque, como bem alertado por BINDER, se não se identificar a razão da existência da forma processual, e o seu objeto de proteção, a mera rotina, os ritos e os ritmos da burocracia judicial é que serão protegidos. ${ }^{165}$

A forma, como exteriorização do ato, fazendo-se uma analogia com o próprio processo penal, representa o limite de atuação do Estado. ${ }^{166}$ Com efeito, o modelo do ato prefixado em lei regula o modo, o lugar e a circunstância em que o poder público poderá apurar a pretensão punitiva que dá ensejo à persecução criminal. Ela (forma) estabelece, em verdade, o conteúdo do freio Estatal na atividade punitiva. ${ }^{167}$

Se é correto dizer que um modelo processual demasiadamente formalista representa um desserviço à sociedade, não é menos verdade afirmar que um sistema processual penal sem forma alguma constitui uma persecução sem limites. ${ }^{168}$ A despeito da dificuldade em lidar com as formas processuais, lembra BINDER que a vantagem de tê-las no ordenamento

\footnotetext{
${ }^{164}$ GLOECKNER, Ricardo Jacobsen. Nulidades no processo penal: introdução principiológica à teoria do ato processual irregular, cit., p. 122.

${ }^{165}$ BINDER, Alberto. El incumplimiento de las formas procesales, cit., p. 43.

${ }^{166}$ Muito embora voltado para a seara civil, valiosas são as palavras de Carlos Alberto Alvaro de Oliveira: "Cumpre inicialmente encarar o problema do formalismo-valorativo na perspectiva do poder estatal, envolvendo, assim, a questão dos limites da soberania, pois a organização do processo, um dos seus aspectos mais importantes, implica indubitável restrição à atividade do Estado, nele representado pelo órgão judicial." (Do formalismo no processo civil. São Paulo: Saraiva, 2009. p. 67).

167، ‘[Las formas] tienen además significación política, ética y jurídica, y constituyen un objeto apreciable del conocimiento teórico jurídico. La garantía de la formalidad judicial significa el cumplimiento de la función estatal en el ámbito de la administración de justicia penal." SCHMIDT, Eberhard. Derecho procesal penal. Trad. José Manuel Nuñez. Editorial Bibliográfica Argentina: Buenos Aires, 1957. p. 22.

${ }^{168}$ Conforme advertia Giuseppe Chiovenda, "entre os leigos, abundam censuras às formas jurídicas, sob a alegação de que as formas ensejam longas e inúteis querelas, e frequentemente a inobservância de uma forma pode acarretar a perda do direito; e ambicionam-se sistemas processuais simples e destituídos de formalidades. A experiência, todavia, tem demonstrado que as formas são necessárias no processo tanto ou mais que em qualquer relação jurídica; sua ausência carreia a desordem, a confusão e a incerteza." (Instituições de direito processual civil. Campinas: Bookseller, 2002. v. 3, p. 6).
} 
supera suas desvantagens, sobretudo por que (i) reduzem as dificuldades de interpretação do sentido do ato, diminuindo o espaço de discricionariedade do juiz, bem como (ii) atuam como um despertador da consciência jurídica, dando ênfase a situações que devem ser tratadas com maior desvelo. ${ }^{169}$

A violência institucionalizada do Estado deve percorrer uma necessária e indeclinável trilha, observando etapas protocolares, as quais, por sua vez, encontram-se estampadas por formas processuais. ${ }^{170}$ Não se pode desconsiderar, logicamente, que um Estado totalitário, antidemocrático, se erige também com esteio em códigos que prezam o excesso de formalidades, primando pelo rigor às solenidades na atividade jurisdicional. ${ }^{171}$ Todavia, não se pode olvidar que o desprestígio completo da forma pode constituir, de forma idêntica, a marca de um Estado despótico. Que não deixa mentir o atual Código de Processo Penal pátrio, fruto dos influxos autoritários do Estado Novo. ${ }^{172}$

À semelhança do que ocorre com a própria função do processo penal, cabe à forma o papel central de proteger o acusado contra as arbitrariedades do Estado. ${ }^{173}$ É ela que ditará os parâmetros e o ritmo para uma intromissão do poder ao bem mais precioso do indivíduo, que é a liberdade. ${ }^{174}$

Considerando a feição constitucional que deve assumir a instrumentalidade do processo penal atualmente, são as formas que permitirão a constante permeabilização das garantias individuais na atividade persecutória. Ao se ditarem as normas de como deve agir o Estado para impor a sua força em desfavor do acusado-débil [Ferrajoli], naturalmente serão incorporadas, por meio de fórmulas legais, restrições de envergadura constitucional para, por exemplo, quebrar o sigilo telefônico, ou proceder a uma busca e apreensão na

\footnotetext{
${ }^{169}$ BINDER, Alberto. El incumplimiento de las formas procesales, cit., p. 36.

${ }^{170}$ LOUREIRO, Antonio Tovo. Nulidades e limitação do poder de punir: análise de discurso de acórdãos do Tribunal de Justiça do Rio Grande do Sul. Rio de Janeiro: Lumen Juris, 2009. p. 25.

${ }^{171}$ Michel Foucault lembra que a própria Inquisição utilizou-se das formas para exercer o domínio do poder de uma classe específica. (A verdade e as formas jurídicas. Rio de Janeiro: Nau Ed., 2003. p. 74 et seq.).

${ }^{172}$ Lê-se na Exposição de Motivos do CPP: “O Processo Penal é aliviado dos excessos de formalismo e joeirado de certos critérios normativos com que, sob o influxo de um mal compreendido individualismo ou de um sentimentalismo mais ou menos equívoco, se transige com a necessidade de uma rigorosa e expedita aplicação da justiça penal”.

${ }^{173}$ Segundo Binder, as formas processuais devem ser baseadas e sustentadas em três funções diferentes: (i) proteção ao sistema de garantias, (ii) princípio da institucionalização do conflito, (iii) princípio da objetividade. O autor, todavia, ensina que, quando há uma colisão entre essas três funções, deve prevalecer o princípio de proteção do imputado, que obriga a resolver o conflito sempre em favor do réu, salvo se houver um real prejuízo. (El incumplimiento de las formas procesales, cit., p. 49-52).

${ }^{174}$ Pela pertinência, há de se recordar a célebre frase de Cecília Meireles: "Liberdade, essa palavra que o sonho humano alimenta que não há ninguém que se explique e ninguém que não entende." (Antologia poética. São Paulo: Ed. do Autor. 1965).
} 
residência do acusado. Por isso, não se há de discordar da ideia de que a forma, no processo penal, é garantia.

Precisas são as lições de GiaCOMOLLI: “o processo penal devido é o que formal e materialmente protege os direitos humanos e fundamentais, mormente os de liberdade do cidadão, propiciando a tutela jurisdicional efetiva e uma decisão a ele ajustada. Portanto, ultrapassa a concepção originária dos limites do 'devido processo legal'. A adoção do devido processo, com aplicação das regras convencionais, constitucionais e legais, assecuratórias dos direitos humanos e fundamentais, não significa impunidade, mas aperfeiçoamento do Estado Democrático."

O acusado não opta pela maneira por que vai ser processado criminalmente. Ele, ao contrário, é forçado a se submeter às regras prescritas pelo Estado. Fácil de perceber, portanto, que o due process of law, mais do que um direito do indivíduo, constitui um dever (affirmative obligation) do Estado garantir ao indivíduo um processo justo. ${ }^{176}$ Nesse sentido, ganha destaque a forma dentro do processo, pois somente quando ela for respeitada é que se poderá falar na legitimidade da pena.

São frequentes os pronunciamentos judiciais que, a pretexto de afastar o rigorismo formal e homenagear uma suposta eficiência processual, condescendem com atos realizados em desrespeito às formas estabelecidas em lei. Normalmente alegando que a formalidade não se afigura relevante para que o ato atinja sua finalidade, tais decisões, via de regra, cerram os olhos para o fato de ser a forma, antes de tudo, uma garantia do acusado, residindo nesse aspecto sua função de maior relevância. ${ }^{177}$

Ademais, ao se debruçar sobre o tema, GLOECKNER observa que o modelo acusatório representa um sistema de preservação das formas, notadamente pelo afastamento do juiz da atividade probatória, o que impõe a ele uma função mais rigorosa

\footnotetext{
${ }^{175}$ GIACOMOLLI, Nereu. O devido processo penal, cit., p. 85.

176، A análise histórica das garantias do devido processo legal demonstra que elas nasceram e foram cunhadas para o processo penal, no qual se fazia sentir com mais urgência a preocupação com os direitos do acusado." (GRINOVER, Ada Pellegrini. As garantias constitucionais do processo administrativo sancionatório. Revista do Advogado, São Paulo, ano 34, p. 7, dez. 2014).

177 “Se o juiz, como ser humano que é, não está imune a tais influências, que poucas vezes produz uma odiosa separação maniqueísta (nós, os puros; eles, os criminosos), mais necessário será que o processo penal não possa ser deixado à direção discricionária (não poucas vezes um eufemismo para designar 'arbitrária') dele. As formalidades do processo penal, mais do que as do processo civil, serão, destarte, salvaguardas do réu e condições indispensáveis a que um fair trial seja alcançado." (SUANNES, Adauto. Os fundamentos éticos do devido processo penal, cit., p. 157).
} 
de fiscalização da correção dos atos processuais. ${ }^{178}$ Como observador de fora, deve o magistrado fazer cumprir as regras do jogo.

Por outro lado, o modelo inquisitorial, que se sustentava a partir de uma verdade absoluta, favorecia a mitigação da forma. Com efeito, de acordo com esse sistema processual medieval, cabia ao juiz, na qualidade de investigador (inquisidor), detectar as barreiras que obstruíssem a obtenção da realidade, ignorando, se preciso fosse, os erros in procedendo no decorrer da persecução. Sendo necessário, recorria-se sistematicamente à tortura em busca da verdade. ${ }^{179}$

É, de fato, na relativização da forma que se verificam as maiores arbitrariedades do processo penal contra o acusado, contribuindo para essa realidade, em grande medida, a má interpretação que se dá atualmente ao princípio pas de nullité sans grief. Sob o signo de uma instrumentalidade das formas, ignoram-se as mais basilares normas processuais, esquecendo-se que elas, na verdade, representam a materialização de direitos e garantias fundamentais.

O estudo das nulidades deve partir, portanto, dessa concepção de que a forma constitui uma garantia do acusado contra uma agressão desmensurada do Estado. ${ }^{180}$ Por conseguinte, a eventual inobservância dos modelos processuais estabelecidos em lei, $a$ priori configuram a extrapolação dos poderes na atividade persecutória, cabendo ao juiz sanar o vício.

Cumpre dizer que não se defende um absolutismo das formas, caracterizado pela decretação da nulidade para qualquer mácula - por mais insignificante que seja - levada a efeito no caminhar do processo. Por óbvio, existem casos, e a eles se destinará um estudo específico mais adiante, em que, mesmo sendo o ato executado de maneira atípica, não há razão para repeti-lo, sob pena de se priorizar a mera forma em detrimento do correto deslinde do processo penal.

\footnotetext{
${ }^{178}$ GLOECKNER, Ricardo Jacobsen. Nulidades no processo penal: introdução principiológica à teoria do ato processual irregular, cit., p. 124. Da mesma forma, Franco Cordero sustenta que há uma ligação entre os sistemas processuais e a forma. (Procedimiento penal. Trad. Jorge Guerrero. Temis: Santa Fé, 2000. v. 1, p. 88).

${ }^{179}$ De forma contrária, Maria Thereza Rocha de Assis (A prova por indícios. São Paulo: Saraiva, 1994. p. 15) entende que as torturas na fase inquisitorial não guardavam relação com a verdade real: “...embora pudesse parecer que a finalidade da confissão era a busca da verdade material, na realidade desprezava ela a real apreciação jurídica da prova, tornando possível a condenação apenas em face do extremado apego às formas."

${ }^{180}$ Jorge Coutinho Paschoal pontua, com acerto, que "de fato, em um sistema que prescinda completamente dos meios processuais previstos pelo legislador para se alcançar uma verdade processualmente válida, só pode vigorar e imperar a irracionalidade, o abuso, o arbítrio, já que sempre se pode chegar a uma conclusão sem que a hipótese suscitada seja adequadamente testada." ( $O$ prejuízo na teoria das nulidades processuais penais e sua análise jurisprudencial nos Tribunais Superiores. 2014. Dissertação (Mestrado) - Faculdade de Direito da Universidade de São Paulo, São Paulo, 2014. p. 97).
} 
Contudo, muito ao contrário do simples amor à forma, ${ }^{181} \mathrm{o}$ vício processual deve servir como sinal de alerta $^{182}$ ao julgador, o qual terá a obrigação de apurar se tal sinal de fato lesou alguma garantia do acusado inerente à norma. Somente a partir do momento em que se compreender a forma como depositária de limites ao poder de punir, é que será possível avançar no tema das nulidades, e, consequentemente, superar determinados dogmas relacionados à convalidação do ato processual.

181،Sin embargo, la llamada 'nulidad por la nulidad misma' se funda en una verdadera ideología del ritualismo cuyas raíces ya hemos destacado. Ellos no es únicamente una defensa hueca de las formas, sino la utilización de esas formas para el cumplimiento de otras finalidades. Si no se advierte esto con claridad, puede parecer que la visión ritualista es equivocada pero inofensiva". BINDER, Alberto. El incumplimiento de las formas procesales, cit., p. 85.

${ }^{182}$ LOPES JÚNIOR, Aury. Direito processual penal e sua conformidade constitucional, cit., v. 2, p. 432. 


\section{O ATO PROCESSUAL PENAL IMPERFEITO: TRATAMENTO ATUAL DA MATÉRIA E A RETÓRICA DISTORCIDA DA INSTRUMENTALIDADE DAS FORMAS}

O presente capítulo tem por objetivo lançar luzes sobre a atual teoria do ato processual imperfeito no âmbito do processo penal. Conforme se destacou desde o início do trabalho, a maneira como vêm sendo tratados os defeitos processuais revela uma necessidade premente de mudanças, sobretudo no que tange à racionalidade do sistema vigente.

É certo que, a despeito do indigitado diagnóstico, torna-se essencial compreender as bases principiológicas e epistemológicas sobre as quais repousa a contemporânea interpretação dos defeitos relativos aos atos processuais. Com efeito, somente com a identificação da estrutura que sustenta a atual teoria das nulidades é que se poderão detectar os entraves, genuínos gargalos sistêmicos, que impossibilitam uma aplicação da matéria de forma consentânea com a instrumentalidade constitucional almejada pelo processo penal.

Para tanto, e como opção de caminho metodológico, procurar-se-á definir, primeiramente, os pressupostos e requisitos que revestem um ato de validade plena, de forma a, só então, e a partir dessa concepção, estudar as possíveis respostas judiciais em relação aos vícios (patologia) do ato.

\subsection{Ato Processual}

No processo penal, há vasto material concernente aos efeitos jurídicos incidentes sobre os atos processuais defeituosos. Por outro lado, raros são os estudos que se dedicam a estabelecer os elementos necessários para a conformação do ato processual com o modelo legal. Ou seja, estuda-se o remédio (nulidade, irregularidade, etc.) aplicável ao ato viciado, mas ignoram-se os traços essenciais que caracterizam o ato são (perfeito). ${ }^{183}$

\footnotetext{
${ }^{183} \mathrm{~A}$ avalizar tal argumento, basta recorrer aos índices de grande parte do acervo doutrinário relacionado ao processo penal em nosso país. Dificilmente se encontrará lá um capítulo dedicado exclusivamente ao ato processual. Os atos processuais, como regra, são estudados de forma específica, conforme sua previsão no Código de Processo Penal, não havendo uma categoria, por exemplo, de "teoria geral do ato".
} 


\subsubsection{Definição do ato processual: a necessária diferenciação em relação a outros atos jurídicos}

Para principiar, torna-se relevante definir o que é ato processual, situando-o dentro de um estudo mais amplo do Direito. Imprescindível, nesse sentido, diferenciar o ato processual de outros gêneros análogos, justamente para que se possa, posteriormente, identificar as respostas judiciais específicas cabíveis aos vícios dessa estirpe de atos, impedindo que haja uma confusão na matéria central do presente trabalho. ${ }^{184}$ Com efeito, de nada adianta estudar as possíveis sanções processuais a que estão suscetíveis os atos viciados, sem antes estabelecer quais são os atos do processo.

É verdade que o Código de Processo Penal não cuidou de conceituar explicitamente o ato processual. A compreensão do termo deve ser extraída implicitamente do diploma legal, aliado aos ensinamentos doutrinários acerca da matéria, inclusive para definir aquilo que pode estar sujeito, como ato propriamente do processo, à aferição do pas de nullité sans grief como pressuposto para aplicação da sanção de nulidade. ${ }^{185}$

Como é cediço, ato processual é espécie da qual ato jurídico é gênero. Portanto, como primeiro registro, o ato processual - assim como qualquer ato jurídico - nasce da vontade do ser humano, ${ }^{186}$ ou como prefere CALMON DE PASSOS, "podemos distinguir no gênero fato, o fato natural, em que o agente causador é algo que não o homem, do fato do homem, chamado de ato, justamente por ser agente causador da transformação ocorrida o homem com sua conduta."187

A despeito de o aspecto volitivo do ato (gênero) ser indispensável para que ele exista, tal característica é insuficiente para que se faça uma dissociação entre suas diferentes espécies. ${ }^{188}$ Destaque-se, aliás, que grande parte dos problemas relacionados às nulidades está na equiparação frequentemente defendida dos atos jurídicos. Com efeito, a

\footnotetext{
${ }^{184}$ Sobre essa confusão, Borges da Rosa já advertia: "É um fato muito comum a confusão que se costuma fazer entre 'nulidades no processo' e 'nulidades dos atos jurídicos'. Tal confusão verifica-se não só entre as pessoas que discorrem acidentalmente sobre a difícil matéria, quer conversando, quer escrevendo, mas o que é mais de admirar, ocorre em obras impressas sobre a matéria." (Comentários ao Código de Processo Penal, cit., p. 634).

${ }^{185}$ Cumpre observar, nesse ponto, que o Anteprojeto Helio Tornaghi originalmente definia, em seu art. 179, o ato processual como sendo "todo acontecimento natural que tem influência no processo."

${ }^{186}$ É verdade que também há quem preconize não existir, no caso do ato processual, uma voluntariedade propriamente dita, sendo ela substituída por mero reconhecimento de conformidade. Nesse sentido, cf. CORDERO, Franco. Procedura penale. Milano: Giuffrè, 2000. p. 353.

${ }^{187}$ CALMON DE PASSOS, Joaquim. Esboço de uma teoria das nulidades aplicadas às nulidades processuais. Rio de Janeiro: Forense, 2009. p. 20.

188،'Secondo la dottrina, infatti, in primo luogo gli atti processuali sono 'fatti umani', cioè sono constituti da condotte, azioni od omissioni, riferibili ai soggetti del processo ed inseriti nella sequenza procedimentable." (CAPONE, Arturo. L'invalidità nel processo penale. Milano: Cedam, 2012. p. 153).
} 
aplicação de uma espécie de teoria geral dos atos jurídicos, ${ }^{189}$ faz com que conceitos do direito privado sejam transportados diretamente - e sem maiores reflexões - para o processo penal. $^{190}$

Embora estreitamente ligado ao processo civil, SALVATORE SATTA considerava a sede como único critério válido para identificar o ato processual. Segundo o doutrinador italiano, o ato processual constitui elemento indissolúvel do próprio processo, sendo certo que basta examinar o diploma processual para verificar se determinado ato se reveste de processualidade. ${ }^{191}$ Dessa forma, e por maior que seja a aparente simplicidade da afirmação, o ato seria processual justamente porque é "ato do processo". ${ }^{192}$

De outra sorte, há quem entenda que o critério de loco (sede) é inapto a distinguir o ato processual, sendo possível haver atos processuais praticados fora do processo. De forma a encampar essa posição, normalmente são mencionados os exemplos da cláusula arbitral ou mesmo da transação, os quais seriam atos processuais cíveis praticados fora do processo.

De outro lado, FLORIAN sustentava que a definição de ato processual nem estaria relacionada ao local onde fosse produzido, mas, sim, aos sujeitos responsáveis pela sua produção, bem como aos efeitos gerados por ele. Nessa senda, o conceito de ato processual se resumiria aos "fatos praticados pelas pessoas envolvidas no processo, os quais exercem atividade e determinam alguma consequência jurídica dentro do processo, de modo a contribuir para o progresso deste segundo o objetivo que lhe é próprio."193

Com maior foco nos efeitos produzidos, outra tradicional definição sugere ser o ato processual aquele que tem por efeito imediato a constituição, modificação ou extinção de

\footnotetext{
${ }^{189}$ Há quem sustente - posição essa rechaçada no presente trabalho - ser a teoria dos atos jurídicos em geral suficiente para sistematizar o estudo dos atos processuais. Nesse sentido, cf. MARTINEZ, Oscar J. Los vicios del consentimiento en le realización del acto procesal. In: MORELLO, Augusto Mario (Coord.). Estudios de nulidades procesales. Buenos Aires: Hammurabi, 1980. p. 53.

${ }^{190}$ Antonio do Passo Cabral (Nulidades no processo moderno: contraditório, proteção da confiança e validade prima facie dos atos processuais. Rio de Janeiro: Forense, 2010. p. 20) defende a necessária separação entre o estudo dos atos, mormente porque o processo, ramo do direito público, deve conviver com especificidades normativas não encontradas no direito privado, no qual há uma autonomia individual muito maior. No mesmo sentido, assevera Egas Moniz de Aragão (Comentários ao Código de Processo Civil. Rio de Janeiro: Forense, 1974. v. 2, p. 11) "a transposição dos conceitos de Direito Material para o campo do Direito Processual é impossível, salvo que se faça prévia e rigorosa adaptação - o que significa construir a teoria do ato processual -, pois os atos do processo ficam sujeitos a três particularidades marcantes."

${ }^{191}$ Apud CALMON DE PASSOS, Joaquim. Esboço de uma teoria das nulidades aplicadas às nulidades processuais, cit., p. 46.

${ }^{192}$ SATTA, Salvatore. Diritto processual civile. Padova: Cedam, 1948.

${ }^{193}$ FLORIAN, Eugenio. Appunti sugli atti giuridici processuali penali. Estr. da: Rivista Diritto Processuale Penale, Milano, anno 7, n. 7, p. 370-371, 1916.
} 
uma situação jurídica subjetiva processual. ${ }^{194}$ Tal conceito coincidiria, portanto, com a ideia fattispecie processual. Não são poucos os doutrinadores, por outro lado, que advertem para a distorção de vincular a concepção de ato processual à definição de fattispecie, uma vez que, em inúmeros casos, mesmo que haja uma imperfeição relacionada ao modelo descrito na norma, ainda assim poder-se-á falar na existência de um ato processual. ${ }^{195}$

Como primeira observação, e levando em conta as posições supracitadas, torna-se necessário afastar a ideia de que o ato processual, sobretudo na área penal, pode ser definido pela sede, ou seja, apenas pelo fato de ter sido ele praticado dentro do processo. Não é despiciendo lembrar que os atos de investigação levados a efeito no decorrer do inquérito policial também se enquadram na categoria de atos processuais. Assim, ainda que praticados em fase pré-processual, são englobados pela definição de ato processual.

Esse primeiro ponto é de monumental relevância para o tema central do presente trabalho, tendo em vista o argumento, reiterado várias vezes, de inexistir nulidade em atos praticados durante o inquérito policial. ${ }^{196}$ Deveras, não é de hoje que os tribunais pátrios inclinam-se pela tese de que, por ser supostamente um procedimento administrativo, o defeito cometido no inquérito policial não acarreta a nulidade do ato; ou, ainda, eventuais nulidades cometidas no curso da investigação, não contaminamos atos posteriores da ação penal. ${ }^{197}$

Ressalte-se que esse entendimento não deve prosperar. $\mathrm{O}$ modo de conduzir o inquérito policial não é absolutamente discricionário; o que resultaria em uma espécie de “terra de ninguém”. A investigação policial, para além de ser o momento, em toda persecução penal, em que muitas vezes as garantias fundamentais do indivíduo estão mais vulneráveis (ex. quebras de sigilos, busca e apreensão, etc.), os elementos informativos colhidos nessa fase são de extrema importância para o correto desenvolvimento da ação

\footnotetext{
${ }^{194}$ CHIOVENDA, Giuseppe. Instituições de direito processual civil, cit., v. 3, p. 187. O doutrinador uruguaio Eduardo Couture (Fundamentos do direito processual civil. Trad. Benedicto Giaccobini. Campinas: Red Livros, 1999) também associava o conceito de ato processual à produção dos efeitos dentro do processo.

${ }^{195}$ CAPONE, Arturo. L'invalidità nel processo penale, cit., p. 154.

${ }^{196}$ Segundo Fernando da Costa Tourinho, "[o inquérito policial] é peça meramente informativa e, por isso, não há cuidar-se de nulidade (...) Possível irregularidade do inquérito não pode contaminar o processo, nem mesmo desrespeito a formalidade legal." (Processo penal, cit., v. 3, p. 183). Em sentido contrário, LIMA, Arnaldo Siqueira. Vícios do inquérito maculam a ação penal. Boletim IBCCRIM, São Paulo, ano 7, n. 82, set. 1999.

${ }^{197}$ Cf., STJ, 116.031/PR, 5a T., Rel. Min. Napoleão Nunes Maia Filho, j. 18.3.2010: "O inquérito é um procedimento administrativo inquisitorial, destinado a investigar a notícia da existência de uma infração penal, de maneira a formar a opinio delicti do órgão acusador, titular da ação penal, a fim de evitar acusações infundadas; assim, eventuais nulidades ocorridas no curso desse procedimento não contaminam a Ação Penal, devendo o magistrado competente, se for o caso, desconsiderar provas ilegalmente obtidas quando do recebimento da denúncia." Nesse mesmo sentido, ainda no STJ, HC 113.73/MG, 6 $6^{\mathrm{a}}$ T., Rel. Ministro Og Fernandes, j. 18.8.2009; No STF: RHC 103.581/MS, $1^{\mathrm{a}}$ T., Rel. Ministro Luiz Fux, j. 12.3.2013.
} 
penal. Por óbvio, os vícios praticados na fase policial, por constituírem também atos processuais, estão sujeitos às mesmas sanções impostas aos atos praticados ao longo da ação penal. ${ }^{198}$ Por essa razão, portanto, é que não se pode limitar a definição de ato processual penal à sede na qual foi praticado.

Outrossim, além do aspecto de loco, parece ser insuficiente, para se chegar a uma definição atual de ato processual, recorrer a apenas um dos outros critérios (eficácia ou subjetividade). É preciso, na realidade, superar essa antiga divisão estanque que caracterizava o ato processual era caracterizado por apenas um dos critérios, dando espaço a um conceito mais aberto, apto a englobar também aspectos peculiares do processo penal.

Nesse sentido, é preciso recorrer à definição de TonINI. Para o doutrinador, o ato processual-penal é aquele produzido por um sujeito processual (juiz, Ministério Público, autoridade policial, etc.) e cuja finalidade é a imposição de uma medida penal (sentença, despacho, etc.). ${ }^{199}$ Muito embora aparentemente simples, a definição se revela completa, de modo que, com base nela, será possível enfrentar as consequências relativas aos vícios do ato processual.

\subsubsection{Das dimensões do ato à fattispecie processual: a fisiologia do ato processual válido}

$\mathrm{O}$ ato processual, assim como qualquer outro fato jurídico, deve ser examinado, para fins de verificar se ele obtém plena realização, em suas três diferentes dimensões: existência, validade e eficácia. ${ }^{200}$ Diz-se, com frequência, que primeiro há de se verificar

\footnotetext{
${ }^{198}$ Ricardo Gloeckner (Nulidades no processo penal: introdução principiológica à teoria do ato processual irregular, cit., p. 405-406), ao criticar a impossibilidade de reconhecimento de nulidade no decorrer do inquérito policial, preceitua que "em realidade seria um mecanismo perfeito para se praticar uma burla de etiquetas sobre os princípios constitucionais. Sabe-se que o inquérito policial acompanha a denúncia e inclusive a doutrina e jurisprudência, em sua grande maioria, não questionam a regra insculpida no art. 155 do CPP: o juiz poderá condenar o réu e fundamentar sua decisão tendo como sustentáculo o inquérito policial, embora não possa, evidentemente, condenar o réu exclusivamente tomando-se o inquérito (...). $\mathrm{E}$ se o juiz fundamenta, no que toca ao inquérito policial, a sentença em ato viciado? Este ato não poderia ser declarado nulo tendo-se em vista que o inquérito policial é mera peça informativa destinada ao oferecimento da denúncia (...) Como resultado, tem-se um ato que não pode ser controlado judicialmente, embora possa servir de motivação em sentença."

${ }^{199}$ TONINI, Paolo. Lineamenti di diritto processuale penale. 8. ed. Milano: Giuffrè, 2010. p. 86. O autor diz que a virtude dessa definição é o fato de poder englobar também os atos praticados na fase pré-processual: "In base a tale definizione rientrano nel concetto di 'atto' sai gli atti delle indagini preliminar (che, ricordiamo, sono compiuti in una fase preprocessuale), sai gli atti dell'udienza preliminare e del giudizio (che fanno parte del processo penale)."

${ }^{200}$ “Os planos de existência, da validade e da eficácia não podem ser confundidos. Embora esses planos estejam estreitamente vinculados e sejam, de certa forma, interconexos, eles não se confundem entre si." (HERTEL, Daniel Roberto. Técnica processual e tutela jurisdicional: a instrumentalidade substancial das formas, cit., p. 82).
} 
se o ato existe; existindo, poderá ele ser ou não válido; se válido for, poderá ou não produzir seus regulares efeitos. Muito embora essa análise encontre campo mais fecundo no direito material privado, ${ }^{201}$ com raros trabalhos sobre do assunto em outras searas, não se há de negar que também no processo penal ela se revista de grande utilidade, sobretudo quando se pretende penetrar o ardiloso campo das nulidades.

Segundo CALMON DE PASsos, ${ }^{202}$ os elementos do ato processual poderiam ser divididos em pressupostos, requisitos e condições. ${ }^{203}$ Em apertada síntese, e simplificando o estudo do tema desenvolvido pelo professor da Universidade Federal da Bahia, os pressupostos estariam ligados à existência, os requisitos, à validade e as condições, à eficácia do ato. $^{204}$

Para se falar em ato, portanto, primeiro há de se observar se presentes os pressupostos, sem os quais sequer se poderá tachá-lo de existente. Esclareça-se que inexiste, no ordenamento pátrio, a descrição dos elementos indispensáveis para que ato atinja o plano de existência. ${ }^{205}$ Trata-se de conceituação dependente da doutrina, que, a bem da verdade, normalmente se dedica ao assunto para cuidar de seu aspecto negativo (inexistência), impondo a compreensão dos pressupostos a partir de uma exegese contrario sensu. ${ }^{206}$

A insuficiência legislativa, em se tratando de pressupostos do ato, revela-se extremamente prejudicial a uma pretendida segurança jurídica. Ao se objetivar construir uma teoria das nulidades minimamente efetiva, por meio da qual os espaços indevidos de

\footnotetext{
${ }^{201}$ Atribui-se a Pontes de Miranda os primeiros estudos, em nosso país, sobre essas três dimensões do fato jurídico, o que se convencionou chamar de "escada pontiana" ou "tricotomia do negócio jurídico."

${ }^{202}$ CALMON DE PASSOS, Joaquim. Esboço de uma teoria das nulidades aplicadas às nulidades processuais, cit., p. 36.

${ }^{203}$ Antonio Junqueira Azevedo utiliza as denominações elementos (plano de existência), requisitos (plano de validade), e fatores (plano de eficácia). (AZEVEDO, Antonio Junqueira de. Negócio jurídico: existência, validade e eficácia. 4. ed. São Paulo: Saraiva, 2010). Com vistas a manter uma uniformidade ao longo do texto, será utilizada a classificação proposta por Calmon de Passos.

${ }^{204}$ Há quem não concorde com esses três planos distintos do ato processual. Em momento oportuno, quando da abordagem do tema da inexistência, ver-se-á que existe doutrina de peso que nega essa categoria no âmbito do processo.

${ }^{205}$ Ao atribuir os pressupostos a denominação elementos essenciais, Gustavo Badaró adverte que "a lei não costuma prever quais são esses elementos essenciais. Em outras palavras, não há elementos seguros para, de acordo com o direito posto, distinguir os elementos essências, cuja inobservância gera a inexistência jurídica do ato, de um lado, dos demais elementos do ato, em relação aos quais a inobservância gera apenas nulidade." (A garantia do juiz natural no processo penal. 2010. Tese (Livre-Docência) - Faculdade de Direito da Universidade de São Paulo, 2010. p. 582).

${ }^{206}$ Como exemplo, de se citar Dinamarco, para quem "Em cinco situações básicas o ato processual é juridicamente inexistente: (a) quando não esteja ligado à vontade de seu aparente autor (falta de assinatura); (b) quando o agente não tem mínimas condições, perante o direito, para realizar o ato; (c) quando o ato não contém conclusão alguma (petição inicial sem pedido, sentença sem dispositivo); (d) quando dita um resultado materialmente impossível; ou (e) quando o resultado ditado afronta normas superiores de proteção do Estado ou ao ser humano." (DINAMARCO, Candido Rangel. Instituições de direito processual civil. 6. ed. São Paulo: Malheiros Ed., 2009. v. 2, p. 603).
} 
arbítrio do juiz sejam reduzidos ao máximo, torna-se imperioso que os conceitos sejam bem delineados, sob pena de se deixar, perigosamente, ao alvedrio do "intérprete da vez" a função de determinar se, naquele caso específico, o vício haverá de ser sanado, ou não. Não foge à regra o estudo das dimensões do ato jurídico, as quais, para adquirirem alguma funcionalidade prático-jurídica, devem ser bem delimitadas.

A comprovar a premente necessidade de se estabelecerem ao menos critérios mínimos sobre o tema, cite-se o artigo 564, IV do Código de Processo Penal. Exsurge da leitura do referido dispositivo legal que a omissão de formalidade que constitua elemento essencial do ato acarretará sua nulidade. Ora, mas o que constitui o elemento essencial do ato? Estaria o legislador cuidando, aqui, dos pressupostos de existência, dos requisitos de validade, de ambos, ou nenhum deles $?^{207}$ Enquanto pairar essa indefinição, espaço para as mais variadas interpretações existirá.

Não se pode, por outro lado, na ânsia de buscar solucionar a problemática própria do processo penal, importar de outras searas do Direito os pressupostos dos atos processuais. ${ }^{208}$ Por maior que seja a conveniência, e por mais adequados que pareçam os estudos de outros ramos, sempre haverá especificidades próprias ao processo penal. ${ }^{209} \mathrm{~A}$ dimensão da existência do ato processual penal, contudo, será novamente abordada mais adiante no tópico correspondente às imperfeições do ato, notadamente na abordagem do instituto da inexistência.

\footnotetext{
${ }^{207}$ A doutrina, nesse ponto, oscila. Entendendo que podem ser tanto os pressupostos de existência quanto os requisitos de validade, cf. NUCCI, Guilherme de Souza. Código de Processo Penal comentado. 6. ed. São Paulo: Ed. Revista dos Tribunais, 2007. No sentido de os requisitos se referirem a pressupostos de existência: "é essencial tudo aquilo sem o qual o ato inexiste. O mais é acidente, não é substância, é apenas circunstancial." (TORNAGHI, Helio. Curso de processo penal, cit., p. 298). Tratando os elementos constantes no art. 564, IV, do CPP, como requisitos de validade, cf. NASSIF, Aramis; NASSIF, Samir. Considerações sobre nulidades no processo penal. 2. ed. Porto Alegre: Ed. Livraria do Advogado, 2012. p. 97.

${ }^{208}$ Antonio Junqueira de Azevedo (Negócio jurídico: existência, validade e eficácia, cit., p. 31-40) ensina que os elementos (pressupostos) do negócio jurídico podem ser separados em gerais (intrínsecos: forma, objeto e circunstâncias negociais; extrínsecos: agente, lugar e tempo), categoriais (naturais e derrogáveis), e particulares (condição, termo e encargo). De se ver que essa classificação não se mostra, nem de perto, útil ao estudo do ato processual, uma vez que no processo penal, logicamente, não há autonomia do agente para regular sua vontade. Indevido seria tratar, nesse sentido, de "circunstâncias negociais" como um pressuposto do ato processual.

${ }^{209}$ Poucos processualistas ousaram indicar os pressupostos necessários para existência do ato. Calmon de Passos (Esboço de uma teoria das nulidades aplicadas às nulidades processuais, cit., p. 35), de forma extremamente coesa e coerente, desenvolveu sua teoria, aplicável, em tese, ao processo civil, bem como ao processo penal, em que descreve ser imprescindível, para configuração do ato, uma determinada forma, um determinado sujeito, e um objeto determinado.
} 
Superado o plano de existência, ou seja, satisfeitos os pressupostos, passa-se à análise do plano da validade do ato. ${ }^{210}$ Etimologicamente, a palavra validade, que deriva do latim valitudo, significa estado de saúde, ou qualidade de saudável. Daí decorrer, no campo do direito, a noção de ato válido como sendo aquele que ostenta a qualidade de estar de acordo com o ordenamento jurídico. ${ }^{211}$

Assim como ocorre no direito material penal, a atividade processual exige uma atuação típica. ${ }^{212}$ Se a tipicidade do delito corresponde à garantia de que o réu somente poderá ser condenado dentro daquele enquadramento legal, a tipicidade processual corresponde à limitação, por meio de formas prefixadas em lei, de atuação estatal na persecutio criminis. ${ }^{213}$ Nas palavras de CALMON DE PASSOS, o tipo (fattispecie) ${ }^{214}$ do ato é o modelo, ou a amostra, do ato que o legislador constrói com o objetivo de regular o procedimento, isto é, fazê-lo idôneo para o fim. ${ }^{215}$

\footnotetext{
210، $P a r a$ que algo valha, é preciso que exista. Somente depois de se afirmar que existe é possível pensar-se em validade ou em invalidade." (PONTES DE MIRANDA, Francisco Cavalcanti. Tratado de direito privado. 4. ed. São Paulo: Ed. Revista dos Tribunais, 1974. t. 4, p. 6-7). Segundo Antonio Junqueira de Azevedo (Negócio jurídico: existência, validade e eficácia, cit., p. 41), em assertiva da qual se discorda, "o plano da validade é próprio do negócio jurídico (...) o papel maior ou menor da vontade, a causa, os limites da autonomia privada quanto à forma e quanto ao objeto são algumas questões que se põem, quando se trata de validade do negócio, e que, sendo peculiares dele, fazem com que ele mereça um tratamento especial diante dos outros fatos jurídicos". Por maior relevância que o plano da validade possa assumir para os negócios jurídicos, não há como descartar o interesse no estudo dessa dimensão para outras espécies de atos jurídicos também.

${ }^{211}$ AZEVEDO, Antonio Junqueira. Negócio jurídico: existência, validade e eficácia, cit., p. 42.

${ }^{212}$ GRINOVER, Ada Pellegrini; FERNANDES, Antonio Scarance; GOMES FILHO, Antonio Magalhães. As nulidades no processo penal, cit., p. 19. Ensina Hélio Tornaghi que "há uma tipicidade processual não diferente da tipicidade material: para que um ato processual produza efeitos, é necessário que se conforme ao modelo legal”. (A relação processual penal. 2. ed. São Paulo: Saraiva, 1987. p. 1990).

${ }^{213}$ “'La legge penale definisce i 'tipi di fatto' che costituiscono reato e le sanzioni previste per coloro che li commettono. La legge processuale penale regola il procedimento mediante il quale si acerta se à stato commesso un fatto di reato, si l'imputato ne è l'autore e, in caso positivo, quale pena debba essergli applicata." (TONINI, Paolo. Manuale di procedura penale. 11. ed. Milano: Giuffrè, 2010. p. 1). Entre nós, estabelecendo com precisão a diferença entre o tipo material e o tipo processual, Calmon de Passos ensina que "enquanto o direito material é qualificador de formas de comportamento, entendendo-se que tudo quanto não proíbe ou considera devido é permitido, o direito processual é predeterminador de uma forma de comportamento. Só o que ele permite é lícito. Há, portanto, prefixados na lei, modelos de conduta aos quais se deve harmonizar o comportamento dos sujeitos para que seja processualmente reconhecível $e$ válido. Esses modelos constituem o tipo: complexo de elementos necessários e suficientes, legalmente preestabelecidos, para determinação de certo efeito jurídico. (Esboço de uma teoria das nulidades aplicadas às nulidades processuais, cit., p. 145).

${ }^{214}$ Carnelutti define fattispecie como sendo a "especie del hecho, o sea aquel tanto que el hecho jurídico el legislador hace ver." (Lecciones sobre el proceso penal. Trad. Santiago Melendo. Buenos Aires: Bosch, 1950. p. 10). Arturo Capone (L'invalidità nel processo penale, cit., p. 28) fornece uma definição ainda mais completa, ao asseverar que "con 'fattispecie', in base alla nozione oggi consolidata, ci si rifersce all'insieme degli elementi tipizzati da una norma condizioni del'effeto giuridico".

${ }^{215}$ CALMON DE PASSOS, Joaquim. Esboço de uma teoria das nulidades aplicadas às nulidades processuais, cit., p. 78. Eros Grau (Por que tenho medo dos juízes?: (a interpretação/aplicação do direito e dos princípios). 6. ed. ref. do: ensaio e discurso sobre a interpretação/aplicação do direito. São Paulo: Malheiros Ed., 2013. p. 163) lembra que os "conceitos tipológicos" (fattispecie) não são conceitos, mas, sim, noções. Para o autor, os "conceitos" são atemporais e a históricos, enquanto as fattispecies são temporais e históricas.
} 
Em uma primeira análise, respeitados todos os requisitos do modelo normativo, de tipicidade processual poder-se-ia falar, ${ }^{216}$ ao passo que, existindo qualquer desconformidade em relação ao modelo legal, o ato seria considerado atípico, acarretando eventual ineficácia desse ato. ${ }^{217}$ Porém, o tipo do ato não é somente o fato previsto na norma. ${ }^{218}$ Para além, compreender a tipologia do ato em sua integralidade significa, antes de tudo, identificar a estrutura que o compõe, ainda que se saiba ser impossível criar um tipo perfeito amoldável a todo caso concreto. ${ }^{219}$

Adiante-se que não se irá aqui mergulhar a fundo no estudo dos elementos constitutivos do ato processual. Não fosse apenas pelas incontáveis classificações, ${ }^{220}$ que nem de longe permitem uma unanimidade acerca do assunto, é também certo que, para fins de investigação do núcleo do presente trabalho, revela-se prescindível analisar temas cuja abstração muitas vezes confunde, ao contrário de elucidar. No entanto, é necessário, conforme mencionado, compreender ao menos os requisitos que tornam o ato processual válido, de modo que possa ser examinada, posteriormente, a sua invalidade.

Ensina DiNAMARCo que o ato processual, para que possa transmitir de maneira fiel e compreensível as intenções ou vontades de seu autor, necessariamente precisa atender a certas exigências de forma, as quais se situam no plano do como, do onde, e do quando (modo, lugar e tempo da realização de cada ato). ${ }^{221}$ Essas exigências, ainda segundo o

\footnotetext{
${ }^{216}$ Antonio Tovo critica a concepção de tipicidade processual sob o argumento de que retrataria uma perspectiva formalista de aplicação das nulidades. (Nulidades e limitação do poder de punir: análise de discurso de acórdãos do Tribunal de Justiça do Rio Grande do Sul, cit., p. 33).

217 “Se a atividade empreendida corresponder ao seu esquema normativo tenderá a produzir os efeitos práticojurídicos queridos pelo agente." (CONDE CORREIA, João. Contributo para análise da inexistência e das nulidades processuais penais, cit., p. 96) Sobre as consequências da atipicidade do ato, inclusive da desconstituição do ato nulo, será dedicado estudo específico adiante, ainda nesse capítulo.

${ }^{218} \mathrm{Cf}$. CALMON DE PASSOS, Joaquim. Esboço de uma teoria das nulidades aplicadas às nulidades processuais, cit., p. 145.

${ }^{219}$ “'́́ quase impossível prever, por mais acurada que seja a diligência, todas as formas derivadas ou secundárias que podem assumir os atos típicos do processo para atender às contingências de cada caso concreto.” LACERDA, Galeno. Despacho saneador. Porto Alegre: La Salle, 1953. p. 69.

${ }^{220}$ Sobre a dificuldade de conceituar e classificar os atos no processo penal, João Conde Correia (Contributo para análise da inexistência e das nulidades processuais penais, cit., p. 88) afirma: "O conceito e a classificação dos actos processuais constituem matérias complexas, que reflectem os malefícios da excessiva adaptação das concepções civilistas e que, hoje, talvez não tenham utilidade suficiente para justificar tanta polémica."

${ }^{221}$ Hélio Tornaghi também observou essas exigências, as quais denominou prazos, sede, e forma do ato processual (Instituições de processo penal. 2. ed. São Paulo. Saraiva: 1977. v. 2, p. 31). Há quem divirja, entendendo que não se pode colocar no contexto geral de "forma do ato" as noções de tempo e lugar, pois essas seriam formalidades que circundam e condicionam a prática de aludidos atos, cf. MITIDIERO, Daniel. O problema da invalidade dos atos processuais no direito processual civil brasileiro contemporâneo. Disponível em: <http://www.abdpc.org.br/abdpc/artigos>. Acesso em: 07 jun. 2013.
} 
autor, poderiam ser subdivididas em gerais (e.g. uso do vernáculo do país), e especiais (e.g. tríplice estrutura da sentença). ${ }^{222}$

Importa dizer que aludidas exigências do tipo processual, diferentemente do que ocorre com o direito substantivo, não estão, na grande maioria dos casos, reguladas em um só artigo de lei; ao revés, as várias proposições contidas no ordenamento jurídico, em conjunto, constituem e descrevem o modelo do ato processual. Nesse sentido, o ato processual constitui um tipo complexo, no qual um ou mais tipos simples funcionam como seu elemento constitutivo. ${ }^{223}$

Apenas a título ilustrativo, há de se tomar como exemplo o tipo processual da citação do réu preso. O Código de Processo Penal, como regra geral, estabelece como ela deve ser realizada (as formalidades do mandado - art. 352), onde (no próprio estabelecimento prisional - art. 360), e quando (nos procedimentos ordinário e sumário, após o oferecimento da denúncia, se o juiz não a rejeitar liminarmente - art. 396). ${ }^{224}$ Portanto, o tipo complexo da citação somente se aperfeiçoará se presentes tais elementos que o constituem.

É verdade, por outro lado, que nem todo tipo processual contém elementos traçados com tantas minúcias, assim como ocorre no caso da citação do acusado. ${ }^{225}$ Porém, para a análise de validade-eficácia de um ato específico, há de se levar em conta sempre a conformação do ato com os elementos, estabelecidos no ordenamento, que devem caracterizá-lo.

Observados os pressupostos e requisitos impostos pela legislação, reputa-se válido o ato. ${ }^{226}$ Ao revés, se a atividade processual empreendida não corresponder ao modelo legal, fala-se em atipicidade, mas não necessariamente em invalidade. ${ }^{227}$ Não por outra

\footnotetext{
${ }^{222}$ DINAMARCO, Candido Rangel. Instituições de direito processual civil, cit., v. 2, p. 548. Tornaghi também elenca a forma, o lugar e o tempo como formadores do tipo processual, acrescentando que cada um deles deve ser estudado com base em seus critérios teleológicos. (Compêndio de processo penal. Rio de Janeiro: José Konfino, 1967. t. 2, p. 613).

${ }^{223}$ CALMON DE PASSOS, Joaquim. Esboço de uma teoria das nulidades aplicadas às nulidades processuais, cit., p. 80.

${ }^{224}$ Segundo Gabriel Di Giulio, “desde éste ángulo, el patrón legal puede prever: tempo, modo, sujeto y forma. Por exemplo: X tempo (plazo) para la realización de Z acto; la exigencia de fundamentación (modo); la participación de ciertas personas (sujeto); y por escrito (forma).” Nulidades procesales, cit., p. 120.

${ }^{225}$ MARQUES, José Frederico. Elementos de direito processual penal, cit., v. 2, p. 84.

226، $L$ 'atto perfetto è quello che è conforme al modello descritto dalla norma procesualle; esso è valido e produce gli effetti giuridici previsti dalla legge primo fra tutti quello di essere utilizatto dal giudice nella decisione. Ovviamente, il suo valore probatorio è valutato liberamente dal giudice, che protrà ritenerlo attendibile o meno." TONINI, Paolo. Manuale di procedura penale, cit., p. 184.

${ }^{227}$ Como se verá adiante, o ato irregular, atualmente reconhecido por grande parte da doutrina, ainda que atípico, é válido. De se consignar que o conceito de invalidade não encontra unanimidade na doutrina. Não são poucos aqueles que entendem ser o termo invalidade um adjetivo de nulidade. Por todos, e com menções de outros autores que assim pensam, cf. PASSO CABRAL, Antonio do. Nulidades no processo
} 
razão, CALMON DE PASSOS, com acerto, assevera que a "inadequação (atipicidade) do suposto, por si, não acarreta a invalidade do ato, se a consequência objetivamente prevista pela norma ocorreu",228

Importa assentar que a invalidade do ato não se confunde com a sua perda de eficácia. ${ }^{229} \mathrm{O}$ ato inválido pode muito bem produzir seus efeitos normais, conforme se verá, por exemplo, no estudo dedicado às nulidades relativas. ${ }^{230}$ Também não se há de negar, por maior que seja a estranheza, que um ato válido possa ser ineficaz. ${ }^{231} \mathrm{O}$ ato inválido apenas cria um estado de alerta para o magistrado, o qual, com base nas diretrizes normativas, poderá ou não retirar a eficácia de seus resultados.

O conceito de eficácia encontra-se ligado à ideia de produção de efeitos típicos. ${ }^{232}$ No processo penal, o ato inválido produzirá efeitos até que sobrevenha pronunciamento judicial que determine o contrário. Considerando que não se pode falar em nulidades de pleno direito, próprias do Direito Civil, ainda que o ato processual seja desenvolvido de maneira defeituosa (inválido), ele é apto a produzir seus efeitos como se perfeito fosse, pois a sua ineficácia resta dependente de decisão judicial.

Ressalte-se que o ordenamento penal pátrio, assim como em grande parte dos demais países, tolera alguns desvios em relação aos preceitos postos. E há de ser assim. Fosse o contrário, estar-se-ia diante de um modelo hermético, formalista, despreocupado com a genuína finalidade do processo. É por isso que existem determinados atos que, a despeito de serem produzidos em desconformidade com a estrutura típica, jamais deixarão

moderno: contraditório, proteção da confiança e validade prima facie dos atos processuais, cit., p. 25. A posição adotada pelo presente trabalho é a de que a invalidade, como posta hodiernamente, configura a desobediência à estrutura normativa do tipo processual. A nulidade, por outro lado, seria a sanção possivelmente imposta em decorrência de tal inadequação.

${ }^{228}$ CALMON DE PASSOS, Joaquim. Esboço de uma teoria das nulidades aplicadas às nulidades processuais, cit., p. 39.

${ }^{229}$ Giovanni Conso (Il concetto e le specie d'invalidatà: introduzione alla teoria dei vizi degli atti processuali penali. Milano: Giuffrè, 1972, n. 2, p. 11-12) observa: “As incertezas da doutrina, unidas à falta de clareza da individuação do conceito, servem para explicar amplamente a oscilação terminológica entre invalidade (ou nulidade) e ineficácia, comumente encontrável na legislações. Apud KOMATSU, Roque. Da invalidade no processo civil, cit., p. 29.

${ }^{230}$ Kelsen, em sua teoria pura do direito, ao tratar de validade e eficácia, já fazia a seguinte construção metafórica: "Assim, um homem, para viver, tem de nascer: mas, para permanecer com vida, outras condições têm ainda de ser preenchidas, v.g., tem de receber alimento. Se esta condição não é satisfeita, perde a vida. A vida, porém, não se identifica nem com o fato de nascer nem com o fato de receber alimento. (Teoria pura do direito. Tradução: João Baptista Machado. 7. ed. São Paulo: Martins Fontes, 2006. p. 236).

${ }^{231}$ Como exemplo, de se citar uma sentença condenatória, absolutamente válida, impondo pena de reclusão ao réu. Se o sentenciado, irresignado, interpõe apelação, suspenderá os efeitos do veredicto (art. 597, CPP), e não será recolhido à prisão até o julgamento do recurso.

${ }^{232}$ WAMBIER, Teresa Arruda Alvim. Nulidades do processo e da sentença. 6. ed. São Paulo: Ed. Revista dos Tribunais, 2007. p. 136. 
de produzir seus regulares efeitos, seja justamente pela desnecessidade de impedir a sua eficácia, seja pelo decurso de um prazo preclusivo, seja, ainda, porque tal invalidade passe despercebida, etc. ${ }^{233}$

A decretação da nulidade revela-se como uma forma - e, de fato, apenas uma - de um ato inválido perder a sua eficácia. Entretanto, conforme se verá nos próximos tópicos, o que determina a perda da eficácia de um ato é o grau de atipicidade, sendo certo, portanto, que nem toda nulidade gera automaticamente a perda da eficácia.

\subsection{A classificação das respostas jurídicas à atipicidade processual}

Identificada a fisiologia do ato processual, passa-se ao estudo de seus defeitos. Já se viu que ato típico é aquele que obedece fielmente ao modelo legal, sendo, por outro lado, atípico aquele praticado em desconformidade com o ordenamento. Existem, contudo, graus diversos de atipicidade, sendo certo que, dependendo da maior ou menor inobservância à forma legal, consequências diferentes serão impostas. ${ }^{234}$

Frise-se, a atipicidade processual não gera, por si só, a ineficácia do ato. ${ }^{235}$ É dizer: a atividade processual realizada em desconformidade com o modelo normativo não causará, automaticamente, a desqualificação do seu resultado, tendo em vista que disso dependerá a intensidade do vício. Forçoso concluir, portanto, existir uma distinção entre atipicidade relevante e atipicidade irrelevante. ${ }^{236}$

\subsubsection{Atos irregulares}

Segundo a doutrina majoritária, há casos nos quais a inobservância da forma será de tamanha insignificância que ela deixará de causar qualquer prejuízo à validade do ato. São hipóteses nas quais, em tese, o vício ofenderia requisitos não essenciais dos atos processuais, meramente acessórios, e sem real relevância, não comprometendo, por

\footnotetext{
${ }^{233}$ Esses motivos serão mais bem explorados quando do estudo específico das nulidades.

${ }^{234}$ BADARÓ, Gustavo Henrique Righi Ivahy. A garantia do juiz natural no processo penal, cit., p. 573.

${ }^{235}$ “Si la perfección de los actos procesales o, en general de los actos jurídicos, coincide, como se ha visto, con su eficacia, no se puede decir otro tanto, por el contrario, de los dos conceptos opuestos, como son la imperfección y la ineficacia”. CARNELUTTI, Francesco. Lecciones sobre el proceso penal, cit., p. 182.

${ }^{236}$ CALMON DE PASSOS, Joaquim. Esboço de uma teoria das nulidades aplicadas às nulidades processuais, cit., p. 38.
} 
consequência, a estrutura do ato, nem o interesse das partes. ${ }^{237}$ Tais imperfeições são denominadas de irregularidades. ${ }^{238}$

Apesar de não atender integralmente às exigências dispostas na fattispecie, a deformidade do ato processual irregular não afetaria a consecução da finalidade objetivada pela lei, razão pela qual, com intuito de emprestar máxima celeridade ao processo penal, desnecessário seria a decretação da invalidade nesses casos. ${ }^{239}$

Como exemplos de atos meramente irregulares a doutrina cita, com frequência, o oferecimento de denúncia fora do prazo de quinze dias, em caso de réu solto (art. 46, CPP), ${ }^{240}$ assinatura da sentença com tinta escura e indelével (art. 169, CPC), ou a petição que contenha expressões em outra língua, quando a lei exige a redação em vernáculo (art. $156, \mathrm{CPC}){ }^{241}$

A declaração de eficácia do ato irregular, ainda segundo a tradicional doutrina, seria um desdobramento imprescindível para uma ruptura com o formalismo processual, priorizando a instrumentalidade das formas em detrimento de uma leitura tecnicista do direito. Se a forma não é um fim em si mesma, a sua desobediência, no grau mínimo, e sem

${ }^{237}$ PASSO CABRAL, Antonio do. Nulidades no processo moderno: contraditório, proteção da confiança e validade prima facie dos atos processuais, cit., p. 29-30.

${ }^{238}$ GRINOVER, FERNANDES e GOMES FILHO definem os atos irregulares como sendo aqueles em que o desatendimento às prescrições legais não compromete os objetivos pelos quais a forma foi instituída, sem que sua eficácia esteja em jogo. (Nulidades no processo penal, 12. ed., cit., p. 20) Como destaca Carlos Creus: "No todos os elementos de un acto procesal son requeridos por la ley con la misma intensidad en cuanto su necesariedad. Algunos de ellos sólo están destinados a uniformar los modelos formales para que permitan su inmediata distinción de otros, evitando - por ejemplo - dificultades o demoras en los proveimientos, pero no refieren a sus contenidos con relación a las finalidades básicas de lacto en el proceso; tal puede ser el orden de las enunciaciones de una demanda (en sentido genérico de instamiento). Salvo una disposición en contrario de la ley que expresamente cambie la naturaleza del vicio, el incumplimiento de tales requisitos no desmerece la validez del acto. Trátanse de meras irregularidades." (Invalidez de los actos procesales penales. Buenos Aires: Astrea, 1992. p. 8).

239،"Tuttavia, lórdinamento no decreta l'invaliditá e, quindi, l'inneficacia di ogni difformità, ben potendo ritenere telune di esse del tutto irrilevanti. In tal caso, si resta al di fuori del sistema dell'invalidità delineandosi una mera irregolarità." (CONSO, Giovanni; GREVI, Vittorio. Compendio di procedura penale. 5. ed. Milano: Cedam, 2010. p. 270).

${ }^{240}$ FEITOZA, Denilson. Direito processual penal: teoria, crítica e práxis, cit., p. 886.

${ }^{241}$ BADARÓ, Gustavo Henrique Righi Ivahy. A garantia do juiz natural no processo penal, cit., p. 573. Muito embora os dois últimos dispositivos legais mencionados se refiram ao Código de Processo Civil, não há como descartar a possibilidade de aplicá-los analogicamente no processo penal, ex vi do artigo 3 , do CPP. Sobre o uso do vernáculo nas peças processuais, Dinamarco assevera que "seria insuportavelmente imperfeita uma petição ou sentença inteira, ou capítulos indispensáveis, escritos em uma língua estrangeira, especialmente quando de difícil acesso aos nacionais - porque, assim, a peça processual não teria a capacidade de comunicar aos demais sujeitos do processo as vontades ou intenções de quem a redigiu. Mas não são prejudiciais algumas discretas citações latinas ou o uso de expressões da doutrina estrangeira, ou mesmo algumas transcrições apenas ilustrativas - e por isso, se imperfeição houver, será tão irrelevante perante os escopos a atingir, que o direito processual não a sanciona. Nesses casos o ato é rigorosamente eficaz, não obstante os pequeninos desvios de forma." (Instituições de direito processual civil, cit., v. 2, p. 600). 
afetação de sua finalidade, há de ser considerada mera irregularidade, sendo desnecessário falar em ausência de eficácia do ato nesses casos. ${ }^{242}$

Note-se que, em se tratando de ato irregular, para que assim seja reconhecido, desnecessário seria adentrar a discussão acerca da existência de prejuízo causado pelo vício. Partindo-se do pressuposto de que as consequências geradas pelo ato irregular seriam insignificantes ao processo, indiferente seria a eventual alegação de dano pelas partes. ${ }^{243}$

Difícil tarefa é, contudo, estabelecer o devido limite entre, de um lado, o defeito que caracteriza o ato irregular, e, de outro, aquele que irá gerar a sua nulidade. Se, como é sustentado amiúde, a distinção residisse no grau de inadequação do ato ao modelo legal, qual seria, por assim dizer, o standard máximo de inobservância apto a caracterizar o ato irregular $?^{244}$

Por óbvio que não haveria qualquer dúvida sobre defeitos irrelevantes. Eventual petição firmada em tinta vermelha, a despeito de contrariar preceito normativo, jamais poderia acarretar qualquer prejuízo às partes, daí porque não se questionará a eficácia plena do ato. Da mesma forma, se, durante uma sessão plenária do Tribunal do Júri, um dos jurados permanece sentado durante a exortação prevista no artigo 472, do Código de Processo Penal, não se há de falar em ineficácia do ato. Tais vícios, estreme de dúvidas, não proporiam qualquer óbice para correta aplicação da legislação, e não gerariam prejuízo algum às partes.

No entanto, nem todos os atos ditos irregulares ostentam tamanha obviedade em seus efeitos no âmbito do processo. Por não se tratar de um conceito absoluto, ou que sequer encontre parâmetros normativos, não raras vezes a inobservância caracterizadora do ato irregular poderia, sim, originar um prejuízo, que sequer seria passível, na atual conjuntura, de questionamento no processo.

Tome-se, apenas a título ilustrativo, a hipótese de intempestividade da apresentação das razões do recurso de apelação. A jurisprudência, de forma iterativa, inclina-se no

\footnotetext{
${ }^{242}$ GRINOVER, Ada Pellegrini; FERNANDES, Antonio Scarance; GOMES FILHO, Antonio Magalhães. Nulidades no processo penal, 12. ed., cit., p. 23.

${ }^{243 ،}$ 'L'atto è irregolare se la difformità dal modello legale non rientra in una delle cause di invalidità che sono previste della legge e che abbiamo appena menzionato. Certamente vi è stata una inosservanza di legge nel compiere dell'atto; ma tale inosservanza non è precista a pena di invalidità." (TONINI, Paolo. Lineamenti di diritto processuale penale, cit., p. 99-100).

${ }^{244}$ Nesse sentido, já se pronunciou Giuseppe Fanuli: "non può sfuggire che si trata di criterio non particolarmente rigoroso, per l'ampio margine di opinabilità che lo connota e che, in sede di applicazione, crea questioni complesse e controverse dando l'impressione che tra la categoria della nullità e quelle in esame i confini siano piuttosto labili." (Le nullità nel processo penale. Milano: Giuffrè, 2013. p. 11).
} 
sentido de constituir tal vício apenas uma irregularidade. ${ }^{245}$ Existem casos, contudo, notadamente aqueles em que há réu preso cautelarmente, nos quais o prazo processual estipulado para apresentação das razões constitui verdadeira garantia do acusado, em respeito ao prazo razoável do processo. ${ }^{246} \mathrm{~A}$ preponderar o entendimento de mera irregularidade, incabível seria, inclusive, uma avaliação acerca do desrespeito à garantia constitucional, já que o vício sempre será sanado independentemente do prejuízo constatado.

Em matéria de atos processuais imperfeitos, ver-se-á mais adiante, imperioso que se limite ao máximo o espaço de discricionariedade do magistrado. Inexistindo uma distinção normativa clara acerca do tema, cede-se espaço para que atos manifestamente nulos sejam considerados meras irregularidades, mesmo em patente inobservância ao devido processo legal. $^{247}$

Não se deve, outrossim, confundir ato irregular com o ato que, embora defeituoso, não é considerado nulo. Em outras palavras, não se pode assumir que um ato seja considerado irregular somente porque, em um determinado caso concreto, não foi decretada a sua nulidade. Frise-se: a imperfeição do ato processual (atipicidade) poderá ser de níveis diferentes, gerando, por isso mesmo, consequências diversas. A irregularidade é, no entendimento da doutrina tradicional, o grau mais leve de inadequação do ato ao modelo legal. ${ }^{248}$ É espécie do gênero atipicidade.

\footnotetext{
245،ROCESSO PENAL. RECURSO ESPECIAL. ARTS. 297, 171, § 2º, II, E 304, TODOS DO CÓDIGO PENAL. RECURSO DE APELAÇÃO CRIMINAL. ART. 578 DO CÓDIGO DE PROCESSO PENAL. PRINCÍPIO DA INSTRUMENTALIDADE DAS FORMAS. INTEMPESTIVIDADE. NÃOOCORRÊNCIA. (...) 2. Por outro lado, considera-se a juntada dos autos das razões recursais fora do prazo uma mera irregularidade, também em observância ao princípio da instrumentalidade das formas." (STJ RESP 1038870/PR $-5^{\text {a }}$ Turma - j. 24.11.2008, p. DJ 9.2.2009).

"PENAL. PROCESSO PENAL. PRELIMINAR. RAZÕES RECURSAIS. INTEMPESTIVIDADE. IRREGULARIDADE. CONHECIMENTO DO RECURSO. (...) 1. A apresentação das razões recursais fora do prazo legal constitui mera irregularidade e não acarreta o não-conhecimento do recurso, no caso de ser tempestiva sua interposição. Precedentes" (TRF 3 ${ }^{\text {a }}$ Região - Apel. Crim. 2007.61.03.010158-6 - $5^{\text {a }}$ Turma - j. 16.7.2012 - p. DJU 26.7.2012).

${ }^{246}$ Gustavo Badaró (Processo penal, cit., p. 34) ensina que o direito ao processo em prazo razoável há de ser dividido em dois aspectos: (i) o direito a um processo, qualquer que seja a sua natureza (civil, trabalhista, etc.), em prazo razoável, desprovido de dilações indevidas; (ii) direito do acusado, preso cautelarmente, ser colocado em liberdade se não for julgado em tempo razoável.

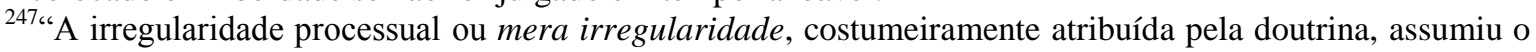
antigo papel reservado à inexistência. A complexidade das relações sociais que se intensifica e a transformação do processo penal contemporâneo tornou obsoleta e anacrônica a manutenção da categoria da inexistência. No entanto, deixou entreabertas as portas para o surgimento de uma nova categoria, embora com finalidade distinta. Cuida-se da irregularidade." (GLOECKNER, Ricardo Jacobsen. Nulidades no processo penal: introdução principiológica à teoria do ato processual irregular, cit., p. 567).

${ }^{248}$ CALMON DE PASSOS, Joaquim. Esboço de uma teoria das nulidades aplicadas às nulidades processuais, cit., p. 111.
} 
Com razão CARnEluTTI, ao asseverar que o ato processual irregular é aquele "afectado por un vicio que no excluye su eficacia." ${ }^{249}$ Válido lembrar, porém, que o mero fato de não retirar a eficácia do ato não é apto, per se, para distinguir a irregularidade de outras espécies de imperfeições. A nulidade relativa - e dela se tratará ainda no presente capítulo -, se não suscitada pela parte tempestivamente, por exemplo, também em nada afetará a eficácia do ato.

Reside justamente na incerteza sobre o contorno exato do instituto da irregularidade grande parte da confusão doutrinária sobre o tema. TOURINHO FILHO, por exemplo, entende que se o Ministério Público arrola 12 testemunhas (em vez de 8) e, inadvertidamente, todas são ouvidas, sendo que oito não sabiam do fato apurado nos autos, haverá mera irregularidade. ${ }^{250}$ Com o devido respeito, não se pode falar em irregularidade na presente hipótese. Não se trata de mera formalidade a ser afastada, ictus oculi. Houve, na espécie, evidente prejuízo (ou, ao menos, potencial prejuízo) à defesa, a qual se viu em desvantagem, pois somente pôde arrolar o número máximo de testemunhas previsto na legislação (8, se de procedimento ordinário se tratar), enquanto à acusação foram concedidos meios de provas mais amplos, vergastando a paridade de armas indispensável em um processo penal constitucional. $\mathrm{O}$ que se pode questionar, nesse caso, quando muito, é o tipo de prejuízo resultante da oitiva de testemunhas acima do número legal, mas jamais se deveria tratar a hipótese como se mera irregularidade fosse, sanável a qualquer momento pelo juiz, independentemente de haver, ou não, prejuízo às partes.

A imprecisão do conceito de ato irregular gera grave insegurança em relação à higidez do sistema processual. ${ }^{251}$ Ao estender seu campo de incidência, notadamente pela ausência de critérios (limites) suficientemente aptos a definir um defeito insignificante, concede-se ao magistrado o poder discricionário de definir as situações, ainda que diante

\footnotetext{
${ }^{249}$ CARNELUTTI, Francesco. Lecciones sobre el proceso penal, cit., p. 182.

${ }^{250}$ TOURINHO FILHO, Fernando da Costa. Processo penal. 34. ed. São Paulo: Saraiva, 2012. v. 3, p. 130.

${ }^{251}$ Já vão longe os dias em que Galdino Siqueira advertia sobre o perigo na ausência de critérios para estabelecer a diferença entre ato irregular e ato nulo: "Lei nacional alguma enumera quaes as formalidades do processo que, preteridas, dão lugar a nullidade, e dahi, e porque nem sempre se teve em vista o critério exposto, a versatilidade e falta absoluta de orientação dos julgados de nossos tribunaes superiores, ora erigindo em nullidades simples irregularidades de formas, ora deixando de pronunciar nullidades manifestas, incertezas que só têm concorrido para o descredito cada vez maior de nossa magistratura, e sacrifício da justiça, que concretisa os próprios interesses sociaes." (Curso de processo criminal. 2. ed. Rio de Janeiro: Livraria e Officinas Magalhães, 1917. p. 417).
} 
de atipicidade, nas quais o ato será declarado válido, mesmo antes de se questionar sobre eventual prejuízo às partes. $^{252}$

Convém destacar que, logicamente, alguns vícios de forma são insignificantes, sendo despiciendas, nesses casos, maiores formalidades para reconhecimento da validade de tais atos. Porém, para uma correta sistematização da matéria, melhor seria tratá-los como erros materiais, e não atos irregulares. Referidos erros podem ser sanáveis de plano pelo magistrado, quando ato do juízo, ou dentro de um determinado prazo, no caso de ser ato das partes, com a condição de que o defeito corrigido não possa, sequer em tese, criar dano às partes. Como regra, os erros materiais estão relacionados a aspectos cosméticos do processo e não encontram forma prevista na legislação em vigor. ${ }^{253}$

De resto, havendo em lei uma forma específica de realização do ato, há de se supor existir uma razão para tanto. Por mais banal que possa parecer o dispositivo legal, não pode tornar-se regra o desrespeito aos seus mandamentos, sob pena de se banalizar o vício em detrimento da higidez do sistema. ${ }^{254}$ A inobservância da norma, portanto, cria um estado de alerta, sendo que tal vício poderá ser sanável ou insanável. ${ }^{255} \mathrm{O}$ ato, no entanto, não poder ser sanado ex officio, sem que se dê a oportunidade para que as partes se manifestem sobre a sua influência nos autos. ${ }^{256}$

\footnotetext{
252،夭́ natural que, como metáfora, que opera no plano da substituição, as irregularidades tendem a ocupar o espaço das nulidades. Essa função expansiva das irregularidades, cada vez mais cristalina diante de breves acompanhamentos jurisprudenciais, traz prejuízos manifestamente graves para a instrumentalidade constitucional do processo penal." (GLOECKNER, Ricardo Jacobsen. Nulidades no processo penal: introdução principiológica à teoria do ato processual irregular, cit., p. 569).

${ }^{253 ،}$ "Nella stesura dela sentenza o di altro provvedimento formale si può incorrere in um errore materiale. $\mathrm{E}$ tale l'errore o l'omissione che no determini nullità e la cui eliminazione non comporti uma modificazione essenziale dell'atto. Se un errore materiale si produca, lo si corregge com procedura de plano." (DALIA, Andrea Antonio; FERRAIOLI, Marcia. Manuale di diritto processuale penale. 7. ed. Padova: Cedam, 2010. p. 372).

${ }^{254} \mathrm{De}$ se retomar o tão repisado exemplo da tinta escura e indelével, que encontra previsão legislativa no art. 169, do Código de Processo Civil. Não se discute que uma sentença subscrita com caneta vermelha jamais perderá a validade, uma vez que dificilmente trará qualquer prejuízo às partes. Por outro lado, deve-se questionar se um veredicto judicial firmado com lápis também ostentaria validade plena. Ao se tachar de mera irregularidade o desrespeito a uma norma, qualquer que seja ela, cria-se o precedente para que, em situações análogas, o magistrado considere o vício como mera irregularidade, impedindo às partes a demonstração de eventual prejuízo.

${ }^{255} \mathrm{~A}$ referida divisão em vícios sanáveis e insanáveis será tratada mais adiante, como uma proposta para modificação do sistema de nulidade aplicável atualmente.

${ }^{256}$ De se lembrar, na esteira de Ricardo Gloeckner (Nulidades no processo penal: introdução principiológica à teoria do ato processual irregular, cit., p. 569), que a arguição de invalidade do ato nem sempre levará à nulidade. Quando desprovida de sentido, a invalidade será rechaçada e o ato processual será mantido.
} 


\subsubsection{Atos inexistentes}

Se, de um lado, a atipicidade em seu grau mais brando é frequentemente classificada como mera irregularidade, não impedindo que o ato produza seu regular efeito processual, de outro, no polo diametralmente oposto, quando verificada uma inadequação tamanha com o modelo legal, fala-se costumeiramente em ato inexistente. ${ }^{257}$

$\mathrm{O}$ ato processual, segundo DINAMARCO, só existe juridicamente quando espelha uma situação típica, que, por sua vez, é composta de forma determinada em lei, pelo sujeito qualificado a realizar o ato, pela vontade do agente, e pelo objeto admissível em direito. Diz-se juridicamente inexistente, destarte, o ato para o qual falte um dos pressupostos mínimos caracterizadores do tipo que aparente reproduzir. ${ }^{258}$ Geralmente é utilizada, para definição da inexistência, a ausência dos elementos essenciais para a constituição do ato. ${ }^{259}$

Note-se que a discussão acerca da inexistência gravita em torno da sua acepção jurídica. Naturalmente que, no plano fático, não há motivo algum para se falar em inexistência - e daí talvez a confusão da nomenclatura utilizada -, uma vez que não há dúvidas de que o ato existe e foi praticado. É sobre a existência do ato no mundo jurídico que recai, portanto, o debate. ${ }^{260}$

À casuística. Suponha-se que, em um determinado processo para apuração de homicídio, sobrevenha decisão impondo prisão preventiva contra o acusado, que de fato, dias depois, é recolhido ao cárcere. Impossível ter ciência à época da prisão, mas o decisum havia sido lavrado pelo escrevente, em vez de sê-lo pelo juiz. Transcorrido um tempo, descobre-se o verdadeiro autor do decreto prisional. Haveria de se considerar a inexistência da sentença? Conforme se verifica, foi prolatada uma sentença; o documento existe. Impende saber, no entanto, se tal veredicto, lavrado por pessoa ilegítima (não juiz), há de ser considerado ato processual.

\footnotetext{
${ }^{257}$ BADARÓ, Gustavo Henrique Righi Ivahy. A garantia do juiz natural no processo penal, cit., p. 573.

${ }^{258}$ DINAMARCO, Candido Rangel. Instituições de direito processual civil, cit., v. 2, p. 587.

${ }^{259}$ PASSO CABRAL, Antonio do. Nulidades no processo moderno: contraditório, proteção da confiança e validade prima facie dos atos processuais, cit., p. 27. Apesar das diferentes nomenclaturas, há de se definir, assim como o faz Calmon de Passos, que existência está ligada a pressupostos, ao passo que a validade do ato está vinculada a requisitos.

${ }^{260}$ José Bedaque faz distinção entre a inexistência material do ato processual e a inexistência jurídica do ato processual. A primeira diz respeito ao ato faticamente inexistente, como, por exemplo, a ausência de citação ou a não-realização de audiência preliminar. A segunda, e essa é a espécie que será tratada no presente tópico, se refere ao ato praticado, mas faltam-lhe os requisitos essenciais para que sobreviva juridicamente. (Efetividade do processo e técnica processual. 2. ed. São Paulo: Malheiros Ed., 2007. ed. São Paulo: Malheiros Ed., 2007. p. 456-462).
} 
Esclareça-se que o conceito de ato inexistente foi inicialmente proposto no direito civil francês, com vistas a buscar uma saída jurídica para declarar sem efeito determinados matrimônios que aviltavam a moral da época. ${ }^{261} \mathrm{~A}$ concepção de ato inexistente ultrapassou os limites do direito de família e do próprio processo civil, e encontrou guarida na teoria geral do direito.

A lei processual não explicita as hipóteses de inexistência dos atos processuais, ficando inteiramente a cargo da doutrina a formulação dos critérios que as identifiquem. ${ }^{262}$ $\mathrm{Na}$ realidade, o ato inexistente constitui categoria conceitual dogmática, fruto de criação doutrinária e jurisprudencial. ${ }^{263}$ Os exemplos de atos inexistentes são clássicos. Dentre eles, já se citou, a decisão judicial prolatado por pessoa não investida na função de magistrado. Da mesma forma, considera-se ato processual inexistente a sentença desprovida da parte dispositiva, ${ }^{264}$ e também a audiência realizada por quem não é advogado.

Segundo CALMON DE PASSOS, a inexistência não guarda qualquer relação com a nulidade. $\mathrm{O}$ ato inexistente é um não-ato ${ }^{265}$ - um não-ser -, e justamente por não existir juridicamente, não se pode atribuir a ele a pecha de viciado ou defeituoso. Seria, ainda segundo o processualista baiano, um conceito que precede o da nulidade, já que, para que seja nulo, primeiro há de ser considerado ato. ${ }^{266}$

\footnotetext{
${ }^{261}$ KOMATSU, Roque. Da invalidade no processo civil, cit., p. 154. O autor exemplifica o que quer dizer com moral da época, ao observar que os casamentos celebrados por pessoas do mesmo sexo, naquele início de século XIX, não estavam previstos como atos nulos, motivo pelo qual seria necessário criar o instituto do ato inexistente para preencher essa lacuna.

${ }^{262}$ O Anteprojeto do Professor Helio Tornaghi de 1962, que nunca entrou em vigor, trazia definição para os atos inexistentes (art. 199): "Consideram-se inexistentes os atos ou negócios jurídicos aos quais falta elemento por lei considerado essencial". No processo civil existe apenas uma hipótese em que a legislação explicitamente declara ser o ato inexistente. Trata-se da propositura da demanda por advogado que afirma ser procurador do autor, mas não o é (CPC, art. 37). Para Pannain, desnecessário que o legislador explicite as causas de inexistência, pois os elementos imprescindíveis para a constituição do ato são deduzidos das normas jurídicas, dos princípios gerais do direito e de todo o complexo do sistema legislativo. (Le sanzioni degli atti processuali penale. Milano: Giuffrè, 1957. p. 254).

${ }^{263}$ ANULI, Giuseppe. Le nullità nel processo penale. Milano: Giuffre, 2013. p. 9.

${ }^{264}$ LOPES JÚNIOR, Aury. Direito processual penal e sua conformidade constitucional, cit., v. 2, p. 417.

${ }^{265}$ Maier chega a afirmar que a inexistência pertence a outro mundo, que não o do processo. (Función normativa de la nulidad. Buenos Aires: De Palma, 1980. p. 141).

${ }^{266}$ CALMON DE PASSOS, Joaquim. Esboço de uma teoria das nulidades aplicadas às nulidades processuais, cit., p. 96. GRINOVER, Ada Pellegrini et al (GRINOVER, Ada Pellegrini; FERNANDES, Antonio Scarance; GOMES FILHO, Antonio Magalhães. As nulidades no processo penal, cit., p. 20) observam que os atos inexistentes "são, na verdade, não-atos, em relação aos quais não se cogita de invalidação, pois a inexistência constitui um problema que antecede a qualquer consideração sobre a validade". Franco Cordero propõe uma analogia entre a nulidade do Direito Civil e a inexistência no processo penal: "Alla nullità dei privatisti corrisponde l'inesistenza dei processualisti, la cui nullità è l'equivalente dell'annullabilità dei primi." (Procedura penale, cit., p. 552).
} 
A inexistência, antes de ser um conceito determinado, é uma ideia reconhecida por meio de proposições negativas. ${ }^{267}$ De acordo com LEONE, a inexistência se determina com base exclusivamente na doutrina, mas que está intimamente ligada com o sistema de nulidades, uma vez que poderiam aspirar à condição de inexistência as imperfeições que não se encontram como causa passível de nulidade. ${ }^{268}$

Diz-se que a inexistência, ao revés do que ocorre com a nulidade, prescinde de declaração judicial de ineficácia, ${ }^{269}$ sendo certo que desde sua gênese os atos inexistentes são impotentes para produção de efeitos. ${ }^{270}$ Nenhuma aquiescência ou decurso de prazo poderá emprestar validade ao ato inexistente. ${ }^{271}$ Nesse sentido, o ato inexistente desafiaria a coisa julgada, sobrevive a ela, ou, inclusive, impede sua constituição. ${ }^{272}$

Há quem negue o conceito de inexistência no processo, dizendo ser suficiente o estudo do instituto das nulidades para cuidar dos atos atípicos. Haveria, segundo aqueles que se filiam a tal posição, uma diferença ontológica entre a nulidade e a inexistência, mas essa distinção não operaria no campo dos atos jurídicos processuais. ${ }^{273}$

GLOECKNER defende ser insustentável a ideia de inexistência, e a considera uma categoria frustrada e improdutiva para o processo penal. A obscuridade do termo, geradora de uma dificuldade de distingui-lo da nulidade absoluta, não justificaria a manutenção do instituto. Não obstante, assevera aludido doutrinador que as bases sobre as quais se sustentaria o conceito da inexistência não encontram razão de ser no processo penal pátrio. Por primeiro, a diferença em relação à formação da coisa julgada não

\footnotetext{
${ }^{267}$ A expressão em itálico pode ser atribuída a Eduardo Couture. Apud MARQUES, José Frederico. Elementos de direito processual penal, cit., v. 2, p. 412.

${ }^{268}$ LEONE, Giovanni. Tratado de derecho procesal penal. Tradução Santiago Melendo. Buenos Aires: Ediciones Juridicas Europa-America, 1963. v. 1, p. 728.

${ }^{269}$ "El acto inexistente no produce efectos jurídicos, y esto de pleno derecho, sin necesidad de declaración del juez." (FLORIAN, Eugenio. Elementos de derecho procesal penal, cit., p. 120).

${ }^{270}$ Carlos Creus sustenta que a categoria da inexistência no processo penal, mais até do que em outros ramos, é absolutamente imprescindível. Pela clareza, vale a transcrição de trecho da obra do autor que aborda o assunto: "Hay defectos - que aunque originados en otros campos del derecho transcienden al procesal - que no sólo le quitan al acto de los efectos en el proceso, sino cualquier efecto para el proceso: como acto procesal es jurídicamente inexistente. La nulidad e inadmisibilidad se engendran en vicios que conmocionan la identidad procesal del acto; la inexistencia se origina en vicios que desplazan su propia juridicidad en general." (Invalidez de los actos procesales penales, cit., p. 11).

${ }^{271}$ KOMATSU, Roque. Da invalidade no processo civil, cit., p. 164.

${ }^{272}$ CALMON DE PASSOS, Joaquim. Esboço de uma teoria das nulidades aplicadas às nulidades processuais, cit., p. 99. "L'inesistenza genera un vizio rilevabile non solo in ogni stato e grado del procedimento, ivi compreso quello di esecuzione, ma anche oltre, mediante una semplice azione di accertamento, in quanto la graivtà del vizio è tale de impedir ela formazione del giudicato." (CONSO, Giovanni; GREVI, Vittorio. Compendio di procedura penale, cit., p. 276).

${ }^{273}$ FERNANDES, Paulo Sergio Leite. Nulidades no processo penal. São Paulo: Ed. Revista dos Tribunais, 1976. p. 26.
} 
corresponde ao modelo brasileiro, o qual prevê a possibilidade de reconhecimento, favor rei, da nulidade absoluta mesmo após o trânsito em julgado. Por segundo, o próprio princípio reitor da inexistência, segundo o qual ela prescindiria de declaração judicial, também esbarraria em questões práticas. Com efeito, o autor pondera que em última instância $\mathrm{o}$ ato supostamente inexistente teria de passar pelo controle judiciário de qualquer forma, uma vez que não teria como reconhecer a qualidade de inexistente por uma via diferente da processual. ${ }^{274}$

Pela lógica que se procura desenvolver ao longo do trabalho, o conceito de inexistência, no âmbito do processo penal, seria indispensável para uma completa teorização dos atos processuais. Com efeito, se o ato aperfeiçoa-se por meio de diferentes dimensões - existência, validade e eficácia -, parece ser inequívoco, sob pena de se negar o que foi defendido até aqui, que inicialmente ele precisa existir para passar ao plano de validade. Não atendidos esses pressupostos essenciais, sequer ato poderá ser ele considerado.

Ocorre que a ausência de critérios normativos para definir a existência do ato impede a identificação dos casos de inexistência. Com o devido respeito à corrente contrária, não se pode construir um conceito assentado em aspectos negativos, sem ao menos estabelecer os contornos mínimos do que se está negando. Em outros termos, incabível aceitar que se apliquem, em casos práticos, as consequências próprias de um ato inexistente, quando desconhecidos os pressupostos que fazem um ato ser tido como existente. ${ }^{275}$

De fato, os atos inexistentes, "que mais habitam o ambiente manualístico, sem qualquer dado na realidade", 276 na atual conjuntura legal do país, não podem ser assim reconhecidos. O ordenamento penal prevê que as hipóteses de imperfeição serão resolvidas pelas regras atinentes às nulidades, inexistindo qualquer disposição sobre defeitos que enfrentem a coisa julgada. ${ }^{277}$ Repita-se: uma teoria minimamente lógica dos atos processuais não há de dispensar a descrição dos pressupostos formadores dos atos processuais, de maneira que se possa, inclusive, identificá-los como tais. Todavia, não se

\footnotetext{
${ }^{274}$ GLOECKNER, Ricardo Jacobsen. Nulidades no processo penal: introdução principiológica à teoria do ato processual irregular, cit., p. 342.

${ }^{275}$ Daí porque Barbosa Moreira insistia na necessidade de se compreender o tema da inexistência pelo seu viés positivo, antes de se partir para a negação. (BARBOSA MOREIRA, José Carlos. Citação de pessoa falecida. In: BARBOSA MOREIRA, José Carlos. Temas de direito processual. São Paulo: Saraiva, 1994. p. 79).

${ }^{276}$ LOPES JÚNIOR, Aury. Direito processual penal e sua conformidade constitucional, cit., v. 2, p. 417.

${ }^{277}$ Jorge Clariá Olmedo sustenta ser desnecessário estudar a inexistência, tendo em vista que ela imporia os mesmos efeitos da nulidade. (Derecho procesal penal. Santa Fe: Rubinzal-Culzoni, 1998. p. 144).
} 
pode, no intuito de preencher uma lacuna legislativa, criar hipóteses de inexistência, com base somente em precedentes ocasionais.

Mais uma vez é preciso defender uma necessária limitação à discricionariedade judicial no tratamento dos atos imperfeitos processuais. A identificação - e manutenção das espécies de vícios deve estar intimamente vinculada à sua aplicabilidade prática. De nada adianta manter institutos próprios do direito civil - que hodiernamente até naquela seara têm sua real utilidade questionada ${ }^{278}$ - que nada (ou pouco) se aplicam ao processo. O estudo empírico tem demonstrado, ademais, que tais institutos, cujas definições não se revelam absolutamente precisas, tendem a um extravasamento exegético acima do desejável, ensejando mais dúvidas ao operador do direito do que soluções práticas.

\subsubsection{Nulidade}

Abordadas as duas consequências limites do vício do ato processual irregularidade e inexistência -, é de se passar ao estudo da nulidade. Dentre os possíveis efeitos do ato processual imperfeito, assume a nulidade particular importância no presente trabalho, uma vez que é a ela que se vincula o princípio do prejuízo. No decorrer do capítulo serão dedicados estudos mais específicos relativos à nulidade, mormente os princípios a ela inerentes, e a sua atual aplicação pelas cortes pátrias, limitando-se, esse subitem, a apenas distingui-la das demais respostas jurídicas ao ato processual imperfeito.

Como já exposto, em se tratando de atipicidade do ato processual, a nulidade é uma de suas possíveis consequências. Mais especificamente, a nulidade traduz-se na retirada de eficácia do ato por uma atipicidade relevante, ${ }^{279}$ ou, por outros termos, no reconhecimento

\footnotetext{
${ }^{278}$ Pontua Sílvio de Salvo Venosa, sobre a inexistência dos negócios jurídicos: “Alguns autores têm a teoria dos atos inexistentes por inconveniente e inútil. Todavia, não podemos negar que por vezes o jurista, perplexo, na enorme variedade de fenômenos que o cerca, encontrará casos típicos de inexistência do ato. Embora se diga que o ato ou negócio inexistente prescinda de declaração judicial, a aparência de ato pode ser tão palpável que a declaração por sentença talvez se mostre necessária. A declaração judicial, no entanto, terá os mesmos efeitos da declaração de nulidade, à qual, para efeitos práticos, a inexistência se assemelha." (Direito civil. 12. ed. São Paulo: Atlas, 2012. v. 1, p. 505-506).

${ }^{279}$ CALMON DE PASSOS, Joaquim. Esboço de uma teoria das nulidades aplicadas às nulidades processuais, cit., p. 125. "Así se obtiene una noción simple y precisa de la nulidad: la pérdida de los efectos propios de un acto procesal por su realización defectuosa, es decir, violando las prescripciones legales que regulaban su forma de producción." (BINDER, Alberto. El incumplimiento de las formas procesales, cit., p. 108).
} 
judicial de que um ato é inapto para atingir a sua finalidade, cujos efeitos devem ser eliminados do mundo jurídico. ${ }^{280}$

Questão de grande polêmica, que tem ensejado controvérsias acadêmicas, reside em saber se a nulidade há de ser considerada uma sanção processual. ${ }^{281}$ Nesse sentido, se a atuação conforme o modelo legal corresponde à tipicidade processual, pode-se concluir, tal como ocorre no campo do direito material, que eventual atipicidade geraria a aplicação de uma sanção processual ${ }^{282}$

Com efeito, doutrinadores há que veem na nulidade uma sanção imposta em razão de um defeito do ato processual. Seria a nulidade, nesse caso, sinônimo de perda de eficácia. Ao se decretar a nulidade, em última instância, estaria o magistrado aplicando uma sanção de ineficácia do ato. Para outra corrente, no entanto, a nulidade não configuraria uma sanção, mas sim uma qualidade ou característica do próprio ato processual. A sanção seria, segundo esse entendimento, a declaração de ineficácia do ato, enquanto a nulidade, aqui, seria empregada no sentido de vício, defeito, ou imperfeição. ${ }^{283}$

Di GIULIO entende ser a nulidade uma sanção processual por meio da qual se priva de efeitos um ato ou conjunto de atos procedimentais incorporados, por carecerem de regularidade em algum de seus elementos estruturais previstos no ordenamento jurídico. ${ }^{284}$ Nesse mesmo sentido, GrinOVER, GOMES FILHO e FERNANDES observam que, ao contrário do ato nulo do direito privado, que prescinde de declaração judicial, no direito processual é necessário impor a sanção de nulidade para que o ato deixe de produzir seus efeitos. ${ }^{285}$

${ }^{280}$ GRINOVER, Ada Pellegrini; FERNANDES, Antonio Scarance; GOMES FILHO, Antonio Magalhães. As nulidades no processo penal, cit., p. 20.

${ }^{281}$ Ao fornecer um panorama regional-histórico dessa questão, Arturo Capone (L'invalidità nel processo penale, cit., p. 111) lembra que "uno dei confini più incerti era quello tra invalidità e sanzione; a grandi linee la tradizione francese, rispecchiata da larga parte della dottrina processuale penale, considerava l'invalidità alla stregua di una reazione di tipo sanzionatorio per l'inosservanza della legge; nella traduzione tedesca, seguita compattamente dalla dalla dottrina civilistica e confermata in sede di teoria generale, l'invalidità coincideva con l'inefficacia."

${ }^{282}$ Não se pode esquecer que no campo do Direito Penal é a tipicidade (e não a atipicidade) que gerará a sanção, uma vez que naquela seara o tipo constitui o injusto penal. Calmon de Passos explica que, enquanto o direito material é qualificador de formas de comportamento, entendendo-se que tudo quanto não pró́be ou considera devido é permitido, o direito processual é predeterminador de uma forma de comportamento. Só o que ele permite é lícito. (CALMON DE PASSOS, Joaquim. Esboço de uma teoria das nulidades aplicadas às nulidades processuais, cit., p. 145).

${ }^{283}$ FEITOZA, Denilson. Direito processual penal: teoria, crítica e práxis, cit., p. 880.

${ }^{284}$ DI GIULIO, Gabriel. Nulidades procesales, cit., p. 120. Não destoa Pisapia, o qual, nesse mesmo sentido, afirma "la nullità è la sanzione prevista per l'inosservanza della forma di un tereminato atto." (Compendio di procedura penale. 5. ed. Padova: Cedam, 1988. p. 124-125).

${ }^{285}$ GRINOVER, Ada Pellegrini; FERNANDES, Antonio Scarance; GOMES FILHO, Antonio Magalhães. As nulidades no processo penal, cit., p. 21. Antonio do Passo Cabral menciona que não há qualquer problema em entender a nulidade como sanção. No entanto, para o autor a nulidade estaria mais ligada a uma 
Não é diferente a posição de BORGES DA ROSA. Com uma objetividade ímpar, ressaltava o autor que "estabelecendo ditas regras ou normas, que são as Leis, não pode o legislador deixar de prever a possibilidade de serem ela violadas, isto é, transgredidas, desobedecidas, infringidas, não cumpridas. Daí a necessidade de uma sanção, de uma pena, com o duplo fim de prevenir uma violação futura e de punir uma violação consumada (...) Entre as diversas sanções, que podem ser aplicadas, a que se apresenta como a mais lógica, pela sua ligação direta com a violação e como efeito imediato da mesma, é a sanção de nulidade, em virtude da qual é considerados como inoperante, sem valor, sem efeito jurídico o ato praticado em desobediência à Lei. Vê-se, portanto, que a sanção de nulidade originou-se da violação da Lei."286

À aludida tese da natureza jurídica da nulidade atrelada à sanção, contudo, existem inúmeros contrapontos. JULIO MAIER, por exemplo, a caracteriza como insustentável, sob o ponto de vista material. Ensina o autor argentino que ínsita ao conceito de sanção é a ideia de prejuízo. A nulidade, em si, não impõe qualquer prejuízo, ainda que em casos particulares possa surtir um efeito prejudicial a um indivíduo determinado. Daí a conclusão de ser a nulidade um conceito neutro. ${ }^{287}$

Refutando também o entendimento majoritário da doutrina acerca do tema, GLOECKNER pondera que existe uma diferença clara entre a declaração da nulidade e a perda dos efeitos do ato viciado. A consequência do reconhecimento da nulidade é a invalidade, o que gera a posterior ineficácia do ato. Portanto, não se confundiria a consequência da nulidade com a própria nulidade. Ademais, consigna o autor que ao se propor, no âmbito do processo penal, uma espécie de analogia com o tipo penal, entende-se a sanção de nulidade como ultima ratio, impossibilitando seja aplicada a casos de menor gravidade. Ocorre que, enquanto no direito penal o princípio da ultima ratio tem por

\footnotetext{
indução comportamental regulatória do que uma sanção negativa. Se há uma tendência à validade dos atos processuais, incorreto imaginar que o Estado deseja desestimular atipicidades formais, ameaçando o agente com uma sanção (Nulidades no processo moderno: contraditório, proteção da confiança e validade prima facie dos atos processuais, cit., p. 205). No mesmo sentido, Teresa Arruda Alvim Wambier entende que a nulidade é o estado em que se encontra um ato, que o torna passível de deixar de produzir seus efeitos próprios e, em alguns casos, destrói os já produzidos. (Nulidades do processo e da sentença, cit., p. 142).

${ }^{286}$ ROSA, Inocencio Borges da. Comentários ao Código de Processo Penal, cit., p. 628.

${ }^{287}$ MAIER, Julio. Función normativa de la nulidad, cit., p. 130-131. No mesmo sentido, entre nós, Roque Komatsu: "A nulidade não representa de per si nenhum prejuízo, ainda que em casos particulares e concretos (reais) possa surgir efeito de prejuízo para um indivíduo determinado (...) Juridicamente, sem embargo, o conceito de nulidade é totalmente neutro, isto é, não representa de per si nenhum prejuízo ou benefício, mas uma crítica à ação levada a efeito incorretamente e, por isso, incapaz de produzir o efeito que a norma lhe assina." (Da invalidade no processo civil, cit., p. 188).
} 
objetivo proteger o sujeito frente ao poder punitivo estatal, no processo penal é a gestão da ilegalidade própria do modelo inquisitório. ${ }^{288}$

Acrescenta RoQue KomATSU que o equívoco de relacionar a invalidade (e todas as suas espécies) a uma sanção reside na falta de clareza ao proceder à distinção entre os institutos de invalidade e ilicitude. Se, em relação a esta última, seria correto falar em reação a um comportamento proibido pela lei, e por isso acertado o termo sanção, na invalidade haveria apenas a insatisfação de um ônus, ${ }^{289}$ razão pela qual incorreto falar-se em sanção. O ato ilícito, continua o autor, "realiza uma fattispecie, o ato inválido não realiza nenhuma fattispecie, antes é inválido justamente por esta razão.",290

O tema é complexo, e o legislador brasileiro não auxilia na sua elucidação. ${ }^{291}$ Parece ser, no entanto, coerente e acertada a posição de CALMON DE PASSOS a respeito do assunto, para quem a nulidade representa uma sanção processual. A imperfeição, o defeito, o vício, diz o processualista, é estado anterior à nulidade. Eventual inobservância do modelo legal resulta na atipicidade do ato processual, mas não gera, automaticamente, a sua nulidade. Há casos, logicamente, em que o defeito do ato pode não gerar a nulidade. Antes de ser declarada a nulidade, o ato imperfeito produz seus regulares efeitos. ${ }^{292} \mathrm{Na}$ qualidade de sanção, a nulidade subtrairá do ato seus efeitos jurídicos em razão da sua atuação contra jure. ${ }^{293}$

Importante mencionar que, de fato, a sanção-nulidade não se confunde com a sanção-pena do direito material. O caráter fragmentário do direito penal, por um lado, revela-se absolutamente imprescindível em um Estado Democrático de Direito. A

\footnotetext{
${ }^{288}$ GLOECKNER, Ricardo Jacobsen. Nulidades no processo penal: introdução principiológica à teoria do ato processual irregular, cit., p. 320.

${ }^{289}$ Sobre o tema "ônus" nas nulidades, já se manifestou o jurista português João Conde Correia: "É certo que alguns autores negam este carácter sancionatório da invalidade e restringem a figura à violação de um ónus processual, configurando-a como um mecanismo de proteção do ordenamento jurídico. Com efeito, segundo os mesmos autores, a qualificação de válido e inválido estaria reservada para os actos lícitos não podendo nunca aplicar-se aos actos ilícitos. Os campos de actuação da ilicitude e da invalidade seriam diferentes, revelando realidades também claramente distintas. Só que tais posições, como reduzido interesse teórico e nenhum interesse prático, não são defensáveis, assentando numa deficiente compreensão da natureza e estrutura das normas processuais penais." (Contributo para análise da inexistência e das nulidades processuais penais, cit., p. 93-94).

${ }^{290}$ KOMATSU, Roque. Da invalidade no processo civil, cit., p. 182.

${ }^{291}$ Uma leitura dos dispositivos insertos no Código de Processo Penal permite interpretar a nulidade ora como sanção, ora como o próprio vício do ato.

292،No creemos que exista una incongruencia teórica mayor en acudir a esa terminología, ya que las normas potestativas también configuran tipo y la consecuencia de su inobservancia puede ser concebida como sanción cuyo contenido final no es el de evitar la actividad extratípica, sino impedir el efecto de la actuación.” CREUS, Carlos. Invalidez de los actos procesales penales, cit., p. 7-8.

${ }^{293}$ CALMON DE PASSOS, Joaquim. Esboço de uma teoria das nulidades aplicadas às nulidades processuais, cit., p. 106.
} 
reprimenda penal, frise-se, há de ser imposta apenas quando as outras esferas do direito forem insuficientes para punir o injusto perpetrado. É, em última análise, a liberdade do indivíduo que se protege com a mínima incidência da punição. Por outro lado, a sanção de nulidade visa restabelecer a higidez do sistema processual, sendo certo que não deve haver qualquer limitação à sua aplicação, senão somente o caráter teleológico da norma violada.

\subsection{Princípios gerais da teoria da nulidade}

Houve um tempo em que toda e qualquer irregularidade processual gerava a perda de eficácia do ato. ${ }^{294}$ Pouco interessava se o desvio do ato era intenso ou insignificante, prejudicial ao processo ou não, ou, ainda, se fora causado propositalmente pelas partes em benefício próprio. O processo, nessa época, ${ }^{295}$ era tido como algo sacramental, sendo certo que as formas constituíam a exteriorização imperiosa desse rito solene. O deslize - por menor que fosse - tornava o ato imprestável. ${ }^{296}$

Acontece que, por óbvio, um modelo extremamente hermético, inclemente com o mais banal dos defeitos, não se coaduna com um processo que se pretenda instrumental, configurando-se, ao contrário, em instrumento teria um fim em si mesmo. Por isso, no decorrer dos anos, foram criados mecanismos normativos para flexibilização dos defeitos processuais, que permitissem o saneamento de imperfeições que não obstruíssem o bom andamento do processo. A seguir, o estudo dessas principais diretrizes que regem a matéria das nulidades demonstrará essa tendência mitigadora das formas processuais. Muito embora seja atribuído a elas o status de "princípio", ver-se-á adiante que normalmente são apenas regras advindas de um dispositivo próprio do Código de Processo Penal. Para fins de facilitação do estudo, ao menos nesse capítulo, será utilizado o nome de princípio nos itens a seguir, assim como faz grande parte da doutrina.

\footnotetext{
${ }^{294}$ FERNANDES, Paulo Sergio Leite. Nulidades no processo penal, cit., p. 5. O autor ainda menciona que a estrutura da época possibilitava a utilização de malícia e má-fé, justamente em virtude do formalismo exacerbado.

${ }^{295}$ Normalmente costuma-se fazer um paralelo entre o caráter extremamente formalista das nulidades e o sistema romano, o qual não permitia o prosseguimento de processo viciado, independentemente da extensão do defeito. O Direito, à época, era exercido por Sacerdotes, atribuindo às formas um caráter religioso de observação solene.

${ }^{296}$ GLOECKNER, Ricardo Jacobsen. Nulidades no processo penal: introdução principiológica à teoria do ato processual irregular, cit., p. 242.
} 


\subsubsection{Princípio da instrumentalidade das formas}

O primeiro "princípio" relativo às nulidades do processo penal está diretamente relacionado ao tema central do trabalho, razão pela qual será ele melhor explorado nos capítulos vindouros. Cabe, por ora, apenas trazer um breve esboço daquilo que a doutrina tem entendido por instrumentalidade das formas.

Nas palavras de MAGalHãEs NoRONHA, “o princípio básico do Código é enunciado logo no início no título referente às nulidades.” Segundo o autor, para explicar aludido princípio, "não existe nulidade desde que da preterição legal não haja resultado prejuízo para uma das partes. Este existe quando não foi alcançado o fim a que a lei tem em vista. Tanto ele pode ocorrer em relação ao acusador, como ao acusado ou à Justiça."297

Eis, portanto, em síntese, o que se entende como "princípio da instrumentalidade das formas". Trata-se de diretriz responsável por conferir aspecto teleológico aos atos processuais, exigindo que o magistrado não se adstrinja somente à literalidade dos dispositivos legais, ${ }^{298}$ mas, acima de tudo, verifique se o vício, no caso concreto, atingiu a finalidade pretendida pelo legislador. ${ }^{299}$ É esse o princípio, em última instância, responsável ceder espaço a causa finalis do ato processual, suplantando o modus faciendi. ${ }^{300}$

Não é incomum ver doutrinadores, que como MAGALHÃES NorONHA trata o princípio da instrumentalidade das formas como sinônimo de princípio do prejuízo. ${ }^{301}$ Ocorre que, como se verá no capítulo seguinte, o prejuízo exigido pela lei para configuração da nulidade (traduzido no brocardo "pas de nullité sans grief”) não deve ser confundido com a ideia de instrumentalidade das formas. É evidente a existência de

\footnotetext{
${ }^{297}$ NORONHA, Edgard Magalhães. Curso de direito processual penal. 5. ed. São Paulo: Saraiva, 1972. p. 325.

${ }^{298}$ É de Tornaghi a lição: "A forma é puramente instrumental; é meio, e não fim." (TORNAGHI, Helio. Curso de processo penal, cit., p. 293).

${ }^{299}$ A doutrina argentina utiliza o nome de "trascendencia". Segundo Gabriel Di Giulio (Nulidades procesales, cit., p. 130), "la irregularidad debe haber afectado un interés. Este presupuesto recibe el nombre de trascendencia."

${ }^{300}$ PASSO CABRAL, Antonio do. Nulidades no processo moderno: contraditório, proteção da confiança e validade prima facie dos atos processuais, cit., p. 45.

${ }^{301}$ Nesse sentido, cf. BADARÓ, Gustavo Henrique Righi Ivahy. Processo penal, cit., p. 577. GLOECKNER, Ricardo Jacobsen. Nulidades no processo penal: introdução principiológica à teoria do ato processual irregular, cit., p. 247. Segundo Ada Pellegrini Grinover et al (As nulidades no processo penal, cit., p. 27) o nome correto seria princípio do prejuízo. Já para Denilson Feitoza (Direito processual penal: teoria, crítica e práxis, cit., p. 882), atribui-se também o nome de princípio da finalidade.
} 
estreita relação entre ambos, mas não parece correto sustentar uma identidade absoluta entre os conceitos, já que distintos. ${ }^{302}$

Com efeito, a instrumentalidade, cujo alcance não se limita apenas ao tema das nulidades, ${ }^{303}$ serve como ideia-reitora para aplicação das formas processuais. Ao ser suscitado um vício no transcorrer do processo, cabe ao magistrado proceder à análise da correlação meio-fim, isto é, se o ato, ainda que defeituoso, cumpriu a função para o qual havia sido estabelecido. ${ }^{304}$ É sob essa perspectiva, aliás, que o legislador de 41 , citando doutrina italiana, justifica a flexibilização de certas formas na Exposição de Motivos do Código de Processo Penal: "um bom processo penal deve limitar as sanções de nulidade àquele estrito mínimo que não pode ser abstraído sem lesar legítimos e graves interesses dos Estados e cidadãos."

Frequentemente, com o fito de demonstrar a aplicabilidade da perspectiva instrumentalista assumida pelas formas no processo penal, cita-se o caso da citação atípica. Nesse sentido, não se declara a nulidade, ainda que a citação seja levada a efeito com inobservância dos preceitos legais, se o acusado tomar conhecimento da acusação e comparecer ao ato para o qual fora intimado. ${ }^{305} \mathrm{~A}$ rigor, nesse caso, o ato, embora maculado, atingiu a finalidade pretendida pelo legislador.

É essa a tendência, ademais, dos modernos estatutos de processo estrangeiros. De fato, embora diferentes entre si, é preciso destacar que em todos os diplomas examinados há dispositivos legais aptos a estabelecer um critério teleológico para as formas. Pode-se concluir, desta maneira, que configuram espécie de respiradouro para o formalismo exacerbado. ${ }^{306} \mathrm{Na}$ lição do português JOÃo CONDE CORREIA, "seria um exagero formal,

\footnotetext{
${ }^{302}$ Apenas adiantando o que será mais bem detalhado adiante, a instrumentalidade das formas consiste em uma ideia reitora do âmbito das nulidades, dentro da qual a regra do princípio estaria inserida. No entanto, assim que como a exigência do princípio, outras regras formariam essa ideia reitora (ex. princípio do interesse). No processo civil, por exemplo, Antonio do Passo Cabral preconiza que existe o "princípio da instrumentalidade", bem como o "princípio do prejuízo." (Nulidades no processo moderno: contraditório, proteção da confiança e validade prima facie dos atos processuais, cit., p. 44-48). Jorge Coutinho Paschoal (O prejuízo na teoria das nulidades processuais penais e sua análise jurisprudencial nos Tribunais Superiores, cit., p. 316) também sugere a diferenciação entre os institutos e prefere sustentar que o prejuízo é uma "projeção da instrumentalidade das formas."

${ }^{303}$ Sobre esse ponto, Candido Dinamarco (A instrumentalidade do processo, cit.) expõe com clareza que um processo instrumental não se confunde com a instrumentalidade das formas.

${ }^{304}$ PASSO CABRAL, Antonio do. Nulidades no processo moderno: contraditório, proteção da confiança e validade prima facie dos atos processuais, cit., p. 46.

${ }^{305}$ O próprio artigo 570, CPP preceitua: “A falta ou a nulidade da citação, da intimação ou notificação estará sanada, desde que o interessado compareça, antes de o ato consumar-se, embora declare que o faz para o único fim de argui-la."

${ }^{306}$ Os exemplos de dispositivos legais que retratam a ideia de instrumentalidade das formas em ordenamentos estrangeiros serão explorados com mais detalhes nos capítulos 3 e 4 do presente trabalho. No entanto, é
} 
destituído de qualquer fundamento substancial, inutilizar a atividade processual desenvolvida, principalmente porque a sua repetição não traz nada que já não tenha sido alcançado.”307

Ressalte-se que a grande problemática envolvendo a instrumentalidade das formas não está, logicamente, em sua essência, mas, sim, na deturpação de seu sentido. ${ }^{308} \mathrm{~A}$ matriz instrumental do ato não significa uma concessão para a condução do processo conforme a vontade do juiz. Se, de um lado, é verdade que não se deve defender um formalismo cego do processo penal, de outro, é preciso entender que a forma, notadamente no processo penal, assume feição garantidora, sendo certo que ela somente será dispensável em casos estritamente delineados pela lei.

Por esse motivo, forçosa a construção de diretrizes responsáveis por conferir o significado próprio da instrumentalidade das formas no processo penal. Nesse plano, de fundamental importância será a propositura, nos capítulos seguintes, de elementos para formulação de uma decisão racional de aferição da regra do prejuízo, permitindo que o caráter instrumental das formas não seja deixado à mera discricionariedade do magistrado em cada caso concreto. ${ }^{309}$

\subsubsection{Princípio do interesse}

Segundo o brocardo do latim, nemo auditur propriam turpitudinem allegans, a ninguém é dado beneficiar-se da sua própria torpeza. Tal orientação, que se espraia por inúmeras áreas do Direito, ${ }^{310}$ constitui a base semântica por detrás do princípio do

possível adiantar que o código italiano prevê, em seu artigo 183, b, que a nulidade será sanada se a parte aproveitar da faculdade a cujo exercício o ato omisso ou nulo se dirigia. Já no EUA, ainda que fundado em um sistema processual diverso, muito se discute sobre o "harmless error", ou seja, o vício ocorrido durante o júri que é insuficiente para anulação do ato (art. 103 (a), Federal Rules of Evidence).

${ }^{307}$ CONDE CORREIA, João. Contributo para análise da inexistência e das nulidades processuais penais, cit., p. 180. A demonstrar a ideia da instrumentalidade das formas, extrai-se do CPP português o seguinte: "Art. 121. Salvo nos casos em que a lei dispuser de modo diferente, as nulidades ficam sanadas se os participantes processuais interessados: a) renunciarem expressamente de argui-las; b) tiverem aceite expressamente os efeitos do acto anulável; ou c) se tiverem prevalecido de faculdade a cujo exercício o acto anulável se dirigia".

${ }^{308}$ Com precisão, Gabriella de Paolo (La sanatoria delle nullità nel processo penale, cit., p. xi) adverte: "Delicato punto di equilíbrio tra esigenze di funzionalità del procedimento ed effettività delle garanzie, l'istituto della sanatoria ha senz'altro un ruolo comprimario nella disciplina delle nullità degli atti processuali."

${ }^{309} \mathrm{Se}$, logicamente, não se pode suprimir por absoluto a discricionariedade do magistrado penal, ao menos se possa, nas palavras de Ferrajoli, atingir certo grau de "discricionariedade dirigida", de forma a impor ao julgador uma motivação em “argumentos cognitivos seguros.” (Derecho y razón, cit., p. 105).

${ }^{310}$ Há doutrina que sustenta ter tal máxima se tornado um princípio geral do direito. No Código Civil, a sua aplicação pode ser verificada em vários momentos. A título de exemplo, cite-se o artigo 183, CC (“não terá direito à repetição aquele que deu alguma coisa para obter fim ilícito, imoral, ou proibido por lei.”). 
interesse, segundo o qual é vedado à própria parte que deu causa ao vício processual, ou àquela que não tenha interesse no seu reconhecimento, pleitear a declaração da nulidade. ${ }^{311}$ É o que se extrai do artigo 565, do Código de Processo Penal. ${ }^{312}$

Recorrendo às palavras de FANULI, "la preclusione alla deduzione della nullità nei confronti della parte che ad essa ha dato o concorso a dar causa è finalizzata a garantire l'obbligo della buona fede nell'esplicazione delle attività processuali e trova la sua giustificazione nel principio secondo cui malitiis est indulgendum: la parte che ha causato un fatoo ingiusto non può pretendere la protezione della legge.”313

De fato, em matéria de vícios, parece ser indispensável que a parte supostamente prejudicada não tenha contribuído propositalmente para a ocorrência do defeito. A nulidade, à evidência, há de servir para reestruturar um processo desalinhando, e não como instrumento a serviço de manobras processuais levadas a efeito pelas partes. ${ }^{314}$

Na tradicional separação entre nulidades absolutas e relativas, há doutrinadores que defendem ser o princípio do interesse apenas aplicável a essas últimas. ${ }^{315}$ Isso porque, as nulidades absolutas cuidariam de vícios de ordem pública, ou seja, cujo interesse transcende às partes, razão pela qual inexistiria óbice para seu reconhecimento. Seguindo essa lógica, se o julgador pode decretar a nulidade ex officio (por ser absoluta), tem ele o dever de reconhecê-la no caso concreto, independentemente de quem tenha dado causa à imperfeição. ${ }^{316}$

\footnotetext{
${ }^{311}$ Como preconizava Magalhães Noronha (Curso de direito processual penal, cit., p. 331), "a nulidade só pode ser arguida por quem nela tem interesse."

312“"Art. 565. Nenhuma das partes poderá arguir nulidade a que tenha dado causa, ou para que tenha concorrido, ou referente à formalidade cuja observância só à parte interesse." No mesmo sentido desse princípio, cf. art. 243, do Código de Processo Civil e art. 796, b, da CLT.

${ }^{313}$ FANULI, Giuseppe Luigi. Le nullità nel processo penale, cit., p. 131. Vale dizer que na Itália, o princípio encontra-se disposto no artigo 182, 1 , CPP.

${ }^{314}$ GLOECKNER, Ricardo Jacobsen. Nulidades no processo penal: introdução principiológica à teoria do ato processual irregular, cit., p. 291.

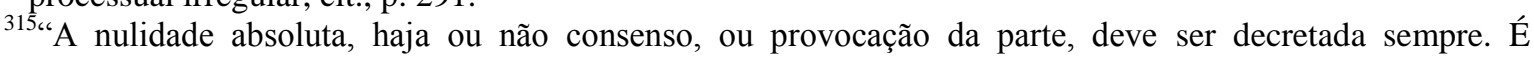
evidente que 'dar causa' ou 'concorrer para a decretação de nulidade', constitui, a par de chicana processual, procedimento antiético intolerável. Isto não impede que a invalidade seja reconhecida, porque, embora carregada de torpeza, a atividade resulta em prejuízo especificamente ressaltado na lei." (FERNANDES, Paulo Sergio Leite; FERNANDES, Geórgia Bajer. Nulidades no processo penal. São Paulo: Ed. Revista dos Tribunais, 1994. p. 214).

${ }^{316}$ BADARÓ, Gustavo Henrique Righi Ivahy. Processo penal, cit., p. 580. O CPP italiano também limita a aplicação do princípio do interesse ao estabelecer que a parte que dê causa ao vício não pode pleitear as nulidades relative ou de regime intermédio (art. 182, 1). Já quanto às nullità assolute não há qualquer vedação nesse sentido.
} 
Outrossim, para ADA PELLEGRINI GRINOver o princípio do interesse é de aplicabilidade extremamente limitada no processo penal, já que o Ministério Público, na teoria, tem o dever de buscar um título executivo válido. Nesse sentido, portanto, a acusação, nas ações estritamente públicas, não pode negar seu interesse na observância rigorosa das normas legais. ${ }^{317}$

A exemplificar a dificuldade de impor a devida limitação ao princípio, importante mencionar a hipótese da ausência de interrogatório do acusado foragido. O Superior Tribunal de Justiça tem entendido que inexiste nulidade na ação penal encerrada sem a realização do interrogatório do réu, quando este não foi localizado única e exclusivamente por conta de sua fuga. Segundo o posicionamento jurisprudencial, o vício decorre da própria torpeza do acusado. ${ }^{318}$ Sem lançar qualquer crítica acerca do conteúdo da decisão até por não ser esse o objeto em estudo -, fica patente a dificuldade, em casos como esses, de definir o verdadeiro "interessado" em fazer com que o acusado seja devidamente interrogado durante o transcurso da persecução penal.

\subsubsection{Princípio da causalidade}

Segundo a lição de EGAS MONIZ DE ARAGÃO, “em um processo ideal não há nulidades e, surgindo alguma, a correção vem incontinenti, antes de se propagar. Tal não é, porém, o que se sucede na realidade; por isso se faz necessário disciplinar os casos ocorrentes, a fim de tentar reduzir ao mínimo as dificuldades resultantes."319 Tendo em vista que a nulidade normalmente é decretada quando o ato viciado já tenha propagado, forçoso que a lei cuide das consequências advindas dessa mácula processual.

O princípio da causalidade trata justamente desses efeitos decorrentes da decretação da nulidade. Considerando que os diversos atos formadores do procedimento são interrelacionados e configuram uma cadeia lógica, tal princípio reza que a nulidade de um ato

\footnotetext{
${ }^{317}$ GRINOVER, Ada Pellegrini. O processo: III Série: estudos e pareceres de processo penal. Brasília: Gazeta Jurídica, 2013. p. 115.

${ }^{318} \mathrm{HC}$ 294.750/PR, $5^{\mathrm{a}}$ T., Rel. Ministro Jorge Mussi, j. 21.8.2014. "Ademais, conquanto o interrogatório seja meio de prova e de defesa, o certo é que a Constituição Federal assegura aos réus o direito ao silêncio, motivo pelo qual tendo o paciente optado por fugir da prisão e não participar do referido ato, não se pode cogitar da obrigatoriedade de sua inquirição antes da prolação de sentença no processo, sendo certo que tal situação se amolda a nenhuma daquelas que a legislação permite a suspensão da tramitação do processo."

${ }^{319}$ MONIZ DE ARAGÃO, Egas. Comentários ao Código de Processo Civil, cit., v. 2, p. 365 . Com propriedade, Fanuli (Le nullità nel processo penale, cit., p. 153) explica que "l'atto processuale non vive isolato, ma in collegamento causale com altri atti dello stesso procedimento nella prospettiva del raggiungimento di um fine comnue: è in quest'ottica che emerce il profilo degli effetti della declaratoria di nullità e della sua estensibilità."
} 
processual contamina todos os posteriores que sejam dele diretamente dependentes, ou mesmo aqueles que surjam como consequência do ato viciado. ${ }^{320}$ Daí decorre também, por via de consequência, que os atos não prejudicados pelo ato originalmente nulo, por serem independentes, serão conservados.

Ao magistrado cabe, portanto, no momento da decretação da nulidade, verificar a extensão do dano processual gerado pela atipicidade, de modo a definir quais atos devem ser necessariamente refeitos. ${ }^{321}$ Como regra, devido ao caráter comunicativo dos atos, a decretação da nulidade exige o retorno do procedimento ao ato originariamente nulo, contaminando todos aqueles derivados dele. ${ }^{322}$ Importa dizer que a classificação da nulidade (absoluta ou relativa) não tem qualquer influência na aplicação do princípio da causalidade. ${ }^{323}$

No entender de AURY LOPES JÚNIOR, em razão do princípio da causalidade, há uma excessiva redução da importância da situação jurídica do processo, que valora isoladamente os atos atípicos, olvidando-se de que todos deveriam estar vinculados com o ato final. Daí porque o autor, em crítica à forma de aplicação do princípio, conclui: "os atos processuais pressupõem que, durante o processo, venha a criar-se uma certa situação jurídica que somente pode constituir-se de forma válida se válidos foram os atos que a precederam, como condicionante será em relação aos atos que na sequência venham a precedê-los.",324

\footnotetext{
${ }^{320}$ GRINOVER, Ada Pellegrini; FERNANDES, Antonio Scarance; GOMES FILHO, Antonio Magalhães. As nulidades no processo penal, cit., p. 29. O princípio encontra guarida no art. $573, \S 1^{\circ} \mathrm{CPP}$ : "A nulidade de um ato, uma vez declarada, causará a dos atos que dele diretamente dependam ou sejam consequência."

${ }^{321 \text { ' } L ' e s t e n s i o n e ~ d e l l a ~ n u l l i t a ̀ ~ t o c c a ~ s o l t a n t o ~ g l i ~ a t t i ~ c h e, ~ o l t r e ~ a d ~ e s s e r e ~ s u c c e s s i v i ~(c o n s e c u t i v i), ~ s i a n o ~ a n c h e ~}$ 'dipendenti' dall'atto viziato (in senso logico e giuridico)." TONINI, Paolo. Lineamenti di diritto processuale penale, cit., p. 108.

${ }^{322}$ Gustavo Badaró (Processo penal, cit., p. 579) faz a diferenciação, para efeito do princípio da causalidade, entre atos praticados na fase postulatória e atos instrutórios. Ocorrido o vício em ato postulatório, haveria uma contaminação automática dos demais atos. Por outro lado, se o vício ocorre em atos instrutórios, em regra, não haveria a afetação de outros atos probatórios realizados posteriormente.

${ }^{323}$ Fazendo um paralelo com o sistema francês, João Conde Correia ensina que "nos sistema jurídico francês os efeitos da declaração de nulidade restringem-se, em regra, ao acto anulado. Porém, algumas nulidades reputadas de maior gravidade transmitem-se, por força de lei ou decisão judicial, aos actos posteriores, viciando todo o processado ou, pelo menos parte dele." (Contributo para análise da inexistência e das nulidades processuais penais, cit., p. 74).

${ }^{324}$ LOPES JÚNIOR, Aury. Direito processual penal e sua conformidade constitucional, cit., v. 2, p. 438.
} 


\subsection{Nulidade Absoluta $x$ Nulidade Relativa}

A doutrina, com intuito de dimensionar a ineficácia do ato processual, distingue as nulidades em absolutas e relativas. ${ }^{325}$ Às primeiras, de acordo com o tradicional entendimento, o ordenamento penal processual confere um tratamento mais severo, ao passo que em relação às relativas, por encerrarem um vício de menor gravidade, o tratamento é mais brando. ${ }^{326}$

Como regra geral, sustenta-se que o critério de distinção se dá com base na natureza ou finalidade do dispositivo violado. ${ }^{327}$ Enquanto, por um lado, a nulidade absoluta seria gerada pela atipicidade do ato em relação à norma protetora de interesse público, por outro, o desrespeito a normas cujo fim seria a tutela de interesses das partes ensejaria a nulidade relativa. ${ }^{328}$ A nulidade absoluta, ainda segundo a distinção doutrinária, estaria vinculada às regras constitucionais de natureza processual, razão pela qual, inobservados os ditames da Carta Constitucional, o vício necessariamente geraria uma nulidade absoluta. ${ }^{329}$

Como decorrência dessa classificação, justamente pelos interesses protegidos, prevalece o entendimento segundo o qual a nulidade absoluta é insanável, ${ }^{330}$ devendo ser,

\footnotetext{
${ }^{325}$ DINAMARCO, Candido Rangel. Instituições de direito processual civil, cit., v. 2, p. 610. De fato, muito embora já utilizada de forma remansosa pelos tribunais, imprescindível esclarecer que referida distinção nasce de estudos doutrinários, e não da lei. Ao que consta, quem primeiro propôs uma sistematização da teoria das nulidades processuais, entre nós, ainda que voltada ao processo civil, foi Galeno Lacerda, em sua obra Despacho saneador, cit.

${ }^{326}$ Florian chegou a diferenciá-los como atos importantes (nulidade absoluta) e menos importantes (nulidade relativa) (Elementos de derecho procesal penal, cit., p. 125).

${ }^{327} \mathrm{Em}$ outras épocas, houve quem sustentasse, para fins de determinar a consequência do vício, uma diferenciação entre formas substanciais e acidentais. No entanto, conforme lembra Magalhães Noronha (Curso de direito processual penal, cit., p. 325), "o Código não observou o sistema que se funda na distinção das formas substanciais e acidentais. Tal classificação, embora já haja predominado na doutrina, ressente-se da dificuldade de se traçar o limite exato entre elas, pelo que não poucos juristas pregavam que se devia deixar ao arbítrio do Juiz o deslinde."

${ }^{328}$ BADARÓ, Gustavo Henrique Righi Ivahy. A garantia do juiz natural no processo penal, cit., p. 574. Nesse mesmo sentido: BEDAQUE, José Roberto dos Santos. Nulidade processual e instrumentalidade do processo. Revista do Processo, São Paulo, ano 15, n. 60, p. 82, out./dez. 1990.

${ }^{329}$ “As garantias constitucionais de conteúdo processual não devem ser vistas apenas sob a ótica individualista, como garantias das partes, mas como regras que asseguram o devido processo legal, sendo fator de legitimação da atividade jurisdicional, havendo evidente interesse público na sua observância." BADARÓ, Gustavo Henrique Righi Ivahy. Processo penal, cit., p. 576. Nesse mesmo sentido, Pacelli, para quem "não é só quando se tem violação a princípios expressamente acolhidos na Constituição é que se poderá falar em nulidade absoluta. Há outros, a serem inferidos do sistema de garantias constitucionais, que, embora não explicitados, integram a estrutura do novo modelo processual penal brasileiro, ainda que como decorrência lógica daqueles expressamente assegurados." Processo e hermenêutica na tutela penal dos direitos fundamentais, cit., p. 816.

330، As nulidades absolutas não se curam. Não há remédio que lhes sirvam. Matam o ato processual, contagiando todos os atos subsequentes." (FERNANDES, Paulo Sergio Leite. Nulidades no processo penal, cit., p. 34). A nulidade absoluta somente seria sanada com o trânsito em julgado, mas especificamente em vício não gerador de prejuízo ao réu, já que este pode valer-se, em tese, de revisão criminal para arguição de ato nulo. Conforme apontado por Ricardo Gloeckner (Nulidades no processo penal: introdução principiológica à teoria do ato processual irregular, cit., p. 356), outros países, tais como
} 
inclusive, declarada de ofício pelo magistrado. ${ }^{331}$ Entende-se, ademais, que inexista um prazo preclusivo para arguição da nulidade absoluta, sendo certo que ela poderia ser declarada a qualquer tempo no decorrer do processo. ${ }^{332}$ Outrossim, nesses casos, dispensável a efetiva demonstração, pela parte interessada do prejuízo causado, já que este seria presumível. ${ }^{333}$

A nulidade relativa, por outro lado, dependeria, para ser reconhecida, de arguição oportuna do interessado, sob pena de preclusão. ${ }^{334}$ Por guardarem relação com atos processuais que tutelam precipuamente interesses particulares, as nulidades relativas seriam passíveis de convalidação, ${ }^{335}$ ignorando-se o defeito e aproveitando o ato praticado. $^{336}$

De se destacar que há quem sustente um critério tríplice, acrescentando, para além das nulidades absolutas e relativas, a categoria da anulabilidade. Seguindo as lições de GALENO LACERDA, ${ }^{337}$ parte minoritária da doutrina entende ser anulável o ato praticado em desconformidade com uma norma dispositiva. ${ }^{338}$ Assim como nas nulidades relativas, a anulabilidade se volta contra atos que tutelem interesses privados, mas, ao contrário da primeira, que se aplica quando a norma violada é cogente, na segunda, a aplicação da regra inobservada está amplamente sujeita às partes. À anulabilidade não serão dedicados

Itália e Argentina, não assumem esse mesmo posicionamento, uma vez que naqueles ordenamentos a coisa julgada torna-se uma sanatória, até mesmo da nulidade absoluta.

${ }^{331}$ Por todos, Ada Pellegrini Grinover et al: "O vício atinge o próprio interesse público de correta aplicação do direito; por isso percebida a irregularidade, o próprio juiz, de ofício, deve decretar a invalidade. (As nulidades no processo penal, cit., p. 21). Na doutrina estrangeira, Paolo Tonini: "Le nullità assolute sono rilevabile anche d'ufficio in ogni stato e grado del procedimento e sono insanabili; in fatti, si possono ritenere sanate soltanto dela irrevocabilità dela sentenza.” TONINI, Paolo. Manuale di procedura penale, cit., p. 193.

${ }^{332}$ No processo civil, mas com aplicação plena no processo penal, de se citar os ensinamentos de Antonio do Passo Cabral: "acompanhando a possibilidade de cognição de ofício, acrescenta a doutrina que o conhecimento das nulidades absolutas não preclui, cabendo sua alegação pela parte e sua decretação pelo juiz a qualquer tempo e em qualquer grau de jurisdição." (Nulidades no processo moderno: contraditório, proteção da confiança e validade prima facie dos atos processuais, cit., p. 35).

333،"Quanto às nulidades absolutas, há presunção legal de prejuízo, não se lhes aplicando, de modo geral, a impeditiva de falta de prejuízo." (FEITOZA, Denilson. Direito processual penal: teoria, crítica e práxis, cit., p. 891) Em sentido contrário: "Não nos parece correto afirmar que, nas nulidades absolutas, o prejuízo seja presumido.” (PACELLI, Eugenio. Curso de processo penal, cit., p. 816). Gustavo Badaró (Processo penal, cit., p. 576), da mesma forma, entende que se aplica às nulidades absolutas também o princípio do prejuízo.

${ }^{334}$ Por todos, DINAMARCO, Candido Rangel. Instituições de direito processual civil, cit., v. 2, p. 613.

335“Tutte la nullità, che non siano insanabili, sono relative" MANZINI, Vincenzo. Trattato di diritto processuale penale italiano. 6. ed. Torino: UTET, 1968. v. 3, p. 130.

${ }^{336}$ PASSO CABRAL, Antonio do. Nulidades no processo moderno: contraditório, proteção da confiança e validade prima facie dos atos processuais, cit., p. 35-36. Tornaghi assevera que "a nulidade relativa pode ser curada, é doença debelável e os remédios para ela recebem o nome de sanatórias." (Compêndio..., p. 614)

${ }^{337}$ LACERDA, Galeno. Despacho saneador, cit., p. 73.

${ }^{338}$ GRECO FILHO, Vicente. Processo penal. 7. ed. São Paulo: Saraiva, 2009. p. 287. No processo civil, MONIZ DE ARAGÃO, Egas. Comentários ao Código de Processo Civil, cit., v. 2, p. 278. 
maiores estudos, uma vez que, consoante entende grande parte dos estudiosos, parece ser essa categoria dispensável ao processo, tendo em vista que ele caracteriza-se por ser instrumento público, cujos dispositivos, pela sua própria natureza, são de aplicação obrigatória. $^{339}$

Esclareça-se que não é possível encontrar, em nossa legislação processual penal, a definição - e, por consequência, a distinção - entre nulidades absolutas e relativas. Tampouco se depreende das disposições normativas qualquer rol de vícios que ensejariam especificamente uma ou outra categoria de nulidade. ${ }^{340}$

$\mathrm{Na}$ realidade, a partir do próprio modelo doutrinário tradicional, distinguindo as nulidades absolutas das relativas pela característica da (in)sanabilidade, prevalece, entre nós, o entendimento de que os vícios de forma descritos nos incisos do artigo 564 do Código de Processo Penal - salvo as exceções constantes do artigo 572 daquele mesmo diploma legal -, insanáveis que são, configuram hipóteses de nulidade absoluta. Por outro lado, as nulidades insculpidas no artigo 572, pela possibilidade de serem sanadas, considerar-se-iam relativas. $^{341}$

\subsubsection{Diferenciação inexistente: a insuficiência de critérios objetivos para classificação das nulidades}

O critério de distinção dúplice das nulidades, que as separa em absolutas e relativas, encontra solo fértil no processo penal. Raras são as vozes contrárias ao modelo já adotado por grande parte da doutrina, ${ }^{342}$ bem como, também quase à unanimidade, pelos tribunais

\footnotetext{
${ }^{339}$ Com extrema propriedade, observa Dinamarco: "Quem quisesse transpor a linguagem do direito privado à técnica das invalidades e da nulificação do ato processual, chegaria a concluir que todo ato processual viciado é anulável; e então não existiriam atos nulos em direito processual, porque sempre a subtração da eficácia do ato viciado só pode vir pela via judiciária. Mas isso seria uma indevida adoção de conceitos e métodos privatísticos, no campo de um ramo jurídico que é eminentemente público.” (DINAMARCO, Candido Rangel. Instituições de direito processual civil, cit., v. 2, p. 608). Nesse mesmo sentido, cf. BADARÓ, Gustavo Henrique Righi Ivahy. A garantia do juiz natural no processo penal, cit., p. 575.

${ }^{340}$ Em sentido contrário, Ada Pellegrini Grinover et al, asseveram que "o artigo 572 do CPP distingue as nulidades absolutas das relativas, prevendo, dentro das hipóteses arroladas pelo art. 564, casos em que o vício de forma estará sanado se a parte não arguir o fato na oportunidade própria (art. 571) ou tiver aceito, ainda que tacitamente, os efeitos do ato irregularmente praticado; nos demais, a nulidade será absoluta (Nulidades no processo penal, 12. ed., cit., p. 21). Com todas as vênias aos grandes mestres, parece que o artigo 572 não distingue as nulidades absolutas das relativas. Os autores, ao que parece, partem de uma classificação doutrinária das nulidades, a qual as separam em insanáveis (absolutas) e sanáveis (relativas), para só então concluir que as hipóteses previstas nos mencionados dispositivos legais estariam enquadradas em uma ou outra classificação.

${ }^{341}$ BADARÓ, Gustavo Henrique Righi Ivahy. Processo penal, cit., p. 576.

${ }^{342}$ Cite-se Calmon de Passos e Ricardo Gloeckner, os quais entendem ser incabível, nesse ponto, a classificação empregada pela doutrina atual.
} 
pátrios. Ocorre que, como já se viu, não é da lei que se extraem os elementos diferenciadores das duas espécies de nulidade, mas, sim, de uma construção doutrinária com base nas finalidades almejadas pelas normas desrespeitadas em razão do vício.

Com efeito, se o defeito de forma ferir a norma protetora de interesse público, é de nulidade absoluta que se falará, ao passo que se a tutela da norma viciada proteger bem particular, então se estaria diante de nulidade relativa. O problema reside justamente em determinar o que caracterizaria, de um lado, norma de salvaguarda de interesse público, e, de outro, norma que tutela interesses particulares. ${ }^{343}$

Se o processo penal é instrumento público, para o qual se confere uma - não a única - função de apuração de um suposto delito, e eventual imposição de sanção institucionalizada, haveria como se falar em normas exclusivamente protetoras de interesses particulares? É dizer, haveria formas que protegeriam, em última instância, interesses das partes?

Conforme visto no capítulo inicial do trabalho, as formas processuais penais têm por escopo central dar efetividade às garantias constitucionais, e impedir, por consequência, o extravasamento do poder de punir estatal. ${ }^{344}$ Inexiste, nesse campo específico, norma voltada para interesse precípuo das partes; ao revés, cabe ao processo penal - por meio dos atos que o formam - assegurar direitos públicos da parte débil contra o Estado. 345

Nas irrepreensíveis palavras de LOPES JR., "a distinção entre normas que tutelam interesse da parte e outras que dizem respeito a interesses públicos tropeça na desconsideração da especificidade do processo penal, onde não há espaço normativo privado. Erroneamente alguns pensam que as normas que tutelam o interesse do réu seriam uma dimensão 'privada', para exigir demonstração de prejuízo". ${ }^{346}$

\footnotetext{
${ }^{343}$ Sobre essa distinção, de se transcrever a posição de Gustavo Badaró (A garantia do juiz natural no processo penal, cit, p. 575): "Deixar ao sabor da doutrina distinguir entre qual norma visa a proteção de interesses público e qual delas tutela interesse particular pode gerar grande incerteza."

${ }^{344}$ SCHMIDT, Eberhard. Derecho procesal penal, cit., p. 22.

${ }^{345}$ Galdino Siqueira, nos idos do ano de 1939, já alertava: "Em processo criminal as nulidades são sempre absolutas, visto consistirem só na preterição de formalidades solemnes e substanciaes prescriptas em attenção ao interesse público, incabível a distinção peculiar no processo civil de nullidades absolutas e nullidades relativas, aquellas referentes ao interesse público e esta a interesse privado." (Curso de processo criminal, cit., p. 417).

${ }^{346}$ LOPES JÚNIOR, Aury. Direito processual penal e sua conformidade constitucional, cit., v. 2, p. 426.
} 
De fato, o critério de distinção das nulidades lastreada na natureza da norma violada origina-se no processo civil. ${ }^{347}$ Nesse ramo, há de se dizer, estando aspartes em igualdade de condições, é possível discutir o interesse tutelado pela norma, sendo ele, ora público, ora exclusivamente particular. Porém, mesmo no processo civil há quem destaque a insuficiência de elementos para identificação do que consistiria o "interesse público" para efeitos de declaração da nulidade. ${ }^{348}$

A teoria da separação das nulidades baseada na finalidade das normas, na doutrina processual penal, se repete à exaustão, como se mera extensão do processo civil fosse. Acontece que, se já é difícil aceitar a hipótese teórica dessa separação no processo penal, ainda mais complexa é a aplicação desses conceitos no plano empírico. No mais das vezes, ainda que se vincule, como fazem inúmeros processualistas, a norma de interesse público àquela que visa a proteção dos princípios fundamentais do processo, ${ }^{349}$ é certo que, ainda assim, seria de difícil distinção a correta natureza da norma no caso concreto.

De se citar, para fins de análise, a sistemática para inquirição de testemunha adotada pelo Código de Processo Penal, em seu artigo 212, a partir do advento da Lei 11.690/08. Extrai-se do aludido dispositivo legal que as perguntas serão formuladas pelas partes diretamente à testemunha, sendo certo que ao juiz caberia apenas complementar a inquirição sobre pontos não esclarecidos. Considerando, hipoteticamente, que o juiz não conceda a palavra inicialmente às partes, começando ele próprio a formular as perguntas, haverá qual espécie de nulidade?

Tendo em vista que inexiste no artigo 564 do CPP menção específica ao descrito vício, há de se recorrer à tradicional distinção para determinar a natureza da nulidade. Protegeria, enfim, o artigo 212, ao dispor sobre a correta dinâmica para inquirição das

\footnotetext{
${ }^{347}$ Cf. DINAMARCO, Candido Rangel. Instituições de direito processual civil, cit., v. 2, p. 610.

${ }^{348}$ Leonardo Greco assevera ser imprecisa a cláusula "interesse público" como critério para definir os casos de nulidade absoluta. Por ser o interesse público um conceito indeterminado, somente quando ficar perfeitamente caracterizado o interesse público é que se poderia falar em nulidade absoluta. Apud PASSO CABRAL, Antonio do. Nulidades no processo moderno: contraditório, proteção da confiança e validade prima facie dos atos processuais, cit., p. 42-43. Por um viés diverso, porém de igual forma ligado à indeterminação d'alguns conceitos na atual teoria das nulidades, Egas Dirceu de Moniz Aragão assim afirma: "Afigura-se por demais subjetiva a apreciação desses fins de justiça do processo. Vê-se que, ao menos me parece, que - como disse acima e aqui repito - o legislador exerce relevante papel na definição de rumos e na regulamentação de matérias tanto em tema de nulidades quanto em outros, e não incorre em pecado quem reconhece a importância em tal papel e apoia na lei os comentários sobre ela produzidos a título de tentar contribuir para facilitar sua compreensão e aplicação. (Nulidade, invalidade, "jardinagem". In: TESHEINER, José Maria (Coord.). Instrumentos de coerção e outros temas de direito processual civil: estudos em homenagem aos 25 anos de docência do Professor Dr. Araken de Assis. Rio de Janeiro: Forense, 2007. p. 183).

${ }^{349}$ Cf. PACELLI, Eugenio. Curso de processo penal, cit., p. 815.
} 
testemunhas, interesse de caráter público ou particular? A resposta, ao que parece, seria que a norma tutela interesse público, já que transporta ao processo penal as garantias da imparcialidade do juiz e do devido processo legal. ${ }^{350}$

Porém, não é assim que têm se pronunciado os tribunais pátrios. No mais das vezes, o desrespeito aos ditames do artigo 212, segundo as cortes, gera nulidade relativa e exige a demonstração do prejuízo pelas partes, sendo possível concluir, por via de consequência, ser tal norma protetora de interesse particular. ${ }^{351} \mathrm{O}$ erro, ao assim se interpretar a matéria, é evidente. De forma alguma a regra visa proteger um interesse "de parte".

De se observar que até os atos mais tendentes a serem caracterizados como de interesse exclusivo "da parte", não o são, mesmo aos olhos da atual teoria das nulidades, que tende ao relativismo exacerbado das formas. Por exemplo, a ausência de alegações finais (memoriais) em favor do acusado, ${ }^{352}$ segundo entendimento remansoso da jurisprudência, configura nulidade absoluta. ${ }^{353}$ Apresentar argumentos contrários à imputação formulada poderia, em tese, demonstrar aparência de ato de interesse exclusivo do acusado. Porém, o interesse contido na norma, nesse e em qualquer outro caso relativo ao processo penal, transcende a esfera do particular, para atingir uma dimensão pública.

Não se pode, e aqui há de se respeitar o balizado posicionamento da doutrina em sentido contrário, estabelecer a separação entre nulidade absoluta e relativa fincada no interesse tutelado pela norma violada. ${ }^{354} \mathrm{O}$ processo, sobretudo o penal, regula-se por normas cogentes, não cabendo às partes dispor ou optar por sua aplicação em tal ou qual caso.

\footnotetext{
350، Assim sendo, à luz da nova sistemática do art. 212 do CPP, é inadmissível a praxe de muitos juízes que insistem em iniciar a inquirição das testemunhas, permitindo que, depois, mediante reperguntas, as partes complementem a inquirição. O procedimento probatório é exatamente o oposto." BADARÓ, Gustavo Henrique Righi Ivahy. Processo penal, cit., p. 323.

${ }^{351}$ No STF: "HABEAS CORPUS. CONSTITUCIONAL. PROCESSO PENAL. 1.INDÍCIO DE AUTORIA E PROVA DA MATERIALIDADE. IMPOSSIBILIDADE DE REEXAME DE PROVAS EM HABEAS CORPUS. 2. ALEGAÇÃO DE NÃO OBSERVÂNCIA DO ART. 212 DO CÓDIGO DE PROCESSO PENAL, COM ALTERAÇÃO DA LEI N. 11.690/2008. NULIDADE RELATIVA. PREJUÍZO NÃO DEMONSTRADO." (HC 115.336/RS - 2ª Turma - Rel. Carmen Lúcia -j. 21.5.2013, p. 4.6.2013). No STJ: "PENAL E PROCESSO PENAL. AGRAVO REGIMENTAL NO RECURSO ESPECIAL. ART. 212 DO CPP. ORDEM DE INQUIRIÇÃO DE TESTEMUNHAS. ALEGAÇÃO. MOMENTO ADEQUADO. AUSÊNCIA DE DEMONSTRAÇÃ̂O DE PREJUÍZO. NULIDADE RELATIVA. AGRAVO REGIMENTAL DESPROVIDO" (AgRg no REsp 1.320.978 - 5 a Turma - Rel. Marilza Maynard - j. 14.5.2013, p. 20.5.2013).

${ }^{352} \mathrm{Nesse}$ caso, é preciso assumir que não houve debates orais, conforme dispõe o artigo 403 , do CPP, tendo o magistrado concedido prazo para apresentação de memoriais.

${ }^{353}$ TRF1: "PENAL. PROCESSO PENAL. AUSÊNCIA DE ALEGAÇÕES FINAIS. NULIDADE ABSOLUTA. OMISSÃO DOS PRINCÍPIOS CONSTITUCIONAIS DO CONTRADITÓRIO E DA AMPLA DEFESA. PRELIMINAR DE NULIDADE ACOLHIDA". (Apel. Crim. 2004.32.01.000014-6 $3^{\mathrm{a}}$ Turma - Rel. Tourinho Neto - j. 12.6.2007, p. 17.8.2007).

${ }^{354}$ Mesmo no processo civil, onde, em tese, as normas poderiam adquirir uma característica mais privada, Daniel Mitidiero assevera: "De nosso lado, temos dificuldade em identificar 'interesses preponderantemente privados' tutelados por normas processuais no processo civil brasileiro
} 
Trata-se de mais uma - das muitas - concepções importadas diretamente do Direito Civil, sem a necessária adaptação às especificidades do processo penal. Conforme se viu, a manutenção dessa separação baseada em interesses públicos e privados permite um exercício discricionário indevido do magistrado, que poderá, a seu talante, declarar a nulidade relativa ou absoluta, a depender da compreensão que tenha a respeito do interesse tutelado pela norma.

A bem da verdade, da maneira como está atualmente colocado o tema pela doutrina e pela jurisprudência, torna-se impossível prever de antemão se, num dado caso, o magistrado irá definir um determinado vício como apto a gerar uma nulidade absoluta ou uma nulidade relativa. ${ }^{355} \mathrm{~A}$ classificação, que encontra esteio na natureza da norma violada, é insuficiente para estabelecer critério minimamente seguro para diferir um defeito que exige a repetição do ato, de outro que, por ser de grau menor, podeser convalidado.

O que se observa, na prática, é que a nulidade será absoluta quando o magistrado assim o decidir. Se, numa dada hipótese, compreender que houve uma lesão ao "interesse público", então declarará a insanabilidade daquele ato. Por outro lado, se encontrar na norma lesada um "viés particular", então reconhecerá uma nulidade relativa, passível de ser sanada.

Em matéria de nulidades, em que o que está em jogo, em última instância, é a higidez de um instrumento colocado a serviço do acusado para limitar o poder do Estado (que, já se falou, sempre tende a extravasar), há de se ter grande preocupação com o tamanho da fresta disponível à discricionariedade do juiz. Afinal, deixar ao puro alvitre do magistrado a definição de nulidade sanável, sem qualquer baliza normativa para tanto, configura prática das mais perigosas, pois a importância (grau) do defeito dependerá do "humor" do julgador à época. 356

contemporâneo, que vem a ser justamente uma das notas caracterizadoras das nulidades relativas e das anulabilidades." (O problema da invalidade dos atos processuais no direito processual civil brasileiro contemporâneo, cit., p. 10).

${ }^{355}$ Vem a calhar, na oportunidade, a indagação formulada por Gloeckner, "há uma distinção qualitativa entre os interesses jurídicos tutelados pela nulidade relativa e por aqueles da nulidade absoluta?" (Nulidades no processo penal: introdução principiológica à teoria do ato processual irregular, cit., p. 360).

${ }^{356}$ Insuperáveis as palavras de Paulo Sérgio Leite Fernandes, o qual, já em 1976, alertava sobre o perigo de deixar os critérios das nulidades exclusivamente nas mãos do juiz: "Não vemos realmente, na ampliação das nulidades, nenhum dos defeitos apontados. Pode-se afirmar, mesmo, ao contrário de Inocêncio Borges da Rosa, que o sistema judicial é o pior que existe. Demonstra-se com ele, é certo, confiança no Poder Judiciário. Corre-se, a par disto, o risco de transformar o juiz em ditador. Pior a emenda que o soneto." (Nulidades no processo, cit., p. 38). Sobre um estudo aprofundado a respeito do decisionismo judicial, em suas várias vertentes, cf. STRECK, Lenio. O que é isto: decido conforme minha consciência? 4. ed. Porto Alegre: Livraria do Advogado, 2012. 
Necessário esclarecer, outrossim, e antes de encerrar o assunto, que o suposto interesse público protegido pela norma processual penal também não deve guardar relação, independentemente da classificação que se lhe dê, com uma presunção de prejuízo causado pela norma violada, como querem fazer crer os adeptos da teoria atual das nulidades. Isto é: não se pode assumir, no processo penal, por serem as normas protetoras de interesse público, que a sua eventual violação ensejaria, em si, a nulidade do ato. A ideia de presunção do prejuízo, vinculada ao interesse tutelado pelos dispositivos processuais, decorre justamente de uma compreensão equivocada da teoria das nulidades, que será detidamente analisada no capítulo seguinte.

\subsection{Nulidade e Desentranhamento: uma aproximação necessária entre as sanções à prova ilegal e as sanções à prova ilegítima}

Não há dúvida de que a teoria das nulidades, tal como posta atualmente, tem se revelado frágil, sobretudo em virtude dos equivocados e mal utilizados conceitos que formam a sua base estruturante. Nesse sentido, contribui em grande medida para esse cenário a constante discussão que gira em torno da prova ilícita e da prova ilegítima no processo penal. ${ }^{357}$ É certo que tal tema normalmente recebe mais atenção em estudos relacionados à matéria de prova no processo penal. ${ }^{358}$ Porém, faz-se imprescindível dedicar algumas linhas - ainda que breves - ao assunto, de maneira a analisar a eventual repercussão na análise do princípio da instrumentalidade das formas.

Como regra, no Brasil, tem-se adotado a classificação proposta por PIETRO NuvOLONE, ${ }^{359}$ segundo a qual todas as provas contrárias à lei seriam consideradas provas vedadas. Por sua vez, a prova vedada (gênero) se dividiria em duas espécies, ilegítimas e ilícitas. Se, de um lado, as primeiras seriam aquelas que violassem normas processuais, de

\footnotetext{
357، ‘Aquí se encuentra una de las grandes tensiones del proceso penal, que se manifiesta en la jurisprudencia sobre ilicitud de la prueba, es decir, aquellos casos en que la actividad procesal debe ser anulada por violación de las formas legales y ello significa algo muy concreto: perder información que puede ser de vital importancia para la construcción de ese relato final. Pero en un estado de derecho la búsqueda de información tiene estos límites y, con prudencia, se ha preferido sacrificar la verdad antes que facilitar el abuso de poder." (BINDER, Alberto. El incumplimiento de las formas procesales, cit., p. 82).

${ }^{358}$ Sobre a inadequação de colocar o tema como usualmente se faz no Brasil, Gloeckner (Nulidades no processo penal: introdução principiológica à teoria do ato processual irregular, cit., p. 364) adverte que "a matéria da prova ilícita é tratada como uma regra geral previamente às provas em espécie. Dentro da teoria geral da prova, a prova ilícita compreenderia o conjunto de disposições, de caráter constitucional, que limitam a produção probatória por parte do Estado. A ilicitude da prova produzida corresponderia a uma violação de dispositivo constitucional, pelo que se pode considerá-la como inválida. Entretanto, não se pode considerar como tecnicamente correto o tratamento dispensado à prova ilícita."

${ }^{359}$ NUVOLONE, Pietro. Le prove vietate nel processo penale nei paesi di diritto latino. Rivista di Diritto Processuale, Padova, v. 21, II serie, p. 470, 1966.
} 
outro, as provas ilícitas seriam as que violassem lei material ou princípios constitucionais. $^{360}$

Cumpre observar, outrossim, ainda sob enfoque da doutrina tradicional, que as consequências impostas às duas espécies de provas vedadas seriam diferentes. À prova ilegítima (e.g. reconhecimento pessoal, sem observância do art. 226 e seguintes, do CPP), impor-se-ia a sanção de nulidade, ao passo que à prova ilícita, porventura juntada aos autos (e.g. diálogos obtidos por meio de interceptações não autorizadas judicialmente), impor-seia a sanção de inadmissibilidade, sem prejuízo de punição do autor da lesão no plano material (e.g. art. 10, da Lei 9.296/96). ${ }^{361} \mathrm{O}$ ato nulo (prova ilegítima) seria refeito, enquanto a prova inadmissível haveria de ser desentranhada. ${ }^{362}$ Eis, portanto, a classificação utilizada por longos anos, cuja aceitação revelava-se maciça pelos estudiosos do processo penal. ${ }^{363}$

A Lei 11.690/08, no entanto, trouxe nova redação ao artigo 157 do Código de Processo Penal, ${ }^{364}$ suscitando questionamentos concernentes à clássica classificação de provas vedadas. Com efeito, passou o referido dispositivo legal a prever a sanção de inadmissibilidade das provas ilícitas, devendo ser entendidas como tais as obtidas em violação às normas constitucionais e legais. Ou seja, depreende-se de uma leitura técnica do texto legal que, hodiernamente, podem ser consideradas provas ilícitas também aquelas produzidas com inobservância às normas de processo penal, pois, afinal, trata-se de espécie de norma legal. Assim, ao que parece, o legislador pretendeu abandonar, no que se refere às sanções processuais, a tradicional diferenciação entre provas ilícitas e provas ilegítimas,

\footnotetext{
${ }^{360}$ Essa classificação foi adotada no Brasil por Ada Pellegrini Grinover. Em obra conjunta, ensina a autora: “A prova é vedada sempre que for contrária a uma específica norma legal, ou a um princípio de direito positivo (...) Acompanhando essa terminologia, diz-se que a prova é ilegal toda vez que a obtenção caracterize violação de normas legais ou de princípios gerais do ordenamento, de natureza processual ou material. Quando a proibição for colocada por uma lei processual, a prova será ilegítima (ou ilegitimamente produzida); quando, pelo contrário, a proibição for de natureza material, a prova será ilicitamente obtida". (Nulidades no processo penal, 12. ed., cit., p. 127).

${ }^{361}$ GRINOVER, Ada Pellegrini; FERNANDES, Antonio Scarance; GOMES FILHO, Antonio Magalhães. Nulidades no processo penal, 12. ed., cit., p. 127.

${ }^{362}$ A concepção de desentranhamento das provas ilícitas nasce na Constituição de 1988, a qual, em seu artigo $5^{\circ}$, prevê a inadmissibilidade, no processo penal, das provas obtidas por meios ilícitos. Desde 1988, portanto, a doutrina e a jurisprudência já afirmam que a consequência da inadmissibilidade seria o desentranhamento, dos autos, dos elementos de provas produzidos de forma ilícita.

${ }^{363}$ Entre outros, AVOLIO, Luiz Francisco Torquato. Provas ilícitas: interceptações telefônicas, ambientais e gravações clandestinas. 3. ed. São Paulo: Ed. Revista dos Tribunais, 2003. p. 42.

${ }^{364}$ Art. 157, CPP - "São inadmissíveis, devendo ser desentranhadas do processo, as provas ilícitas, assim entendidas as obtidas em violação a normas constitucionais e legais".
} 
assumindo que todas as provas obtidas em desacordo com o ordenamento jurídico seriam ilícitas, e, portanto, inadmissíveis no processo. ${ }^{365}$

Confuso resta o tratamento da matéria nos dias atuais, mormente em razão da nova alteração normativa mencionada. Há quem defenda o equívoco do legislador, ao tachar de ilícita - e não de ilegítima - a prova obtida com violação à lei processual. ${ }^{366}$ De fato, a se tomar como base o ordenamento penal, inexistiria, na prática, qualquer diferença entre a prova obtida em desconformidade com as leis materiais e aquela produzida em desconformidade com o preceito processual.

Não raros são os argumentos que, com base em um suposto critério temporal, entendem ser descabida a unicidade das sanções processuais impostas para a prova ilícita e para a ilegítima. Para quem se filia a tal posicionamento, impõe-se a sanção de nulidade (prova ilegítima) ao ato defeituoso já contido no processo, ao passo que a inadmissibilidade (prova ilícita) se dá por vícios ocorridos antes de a prova ser acostada aos autos. ${ }^{367}$ É esse o entendimento de MARCOS ZILLI, para quem "a ilicitude liga-se ao momento da obtenção o que nos remete a uma atividade extraprocessual. São os clássicos exemplos da confissão obtida mediante emprego de tortura e da apreensão de provas com invasão de residência. Reforça-se, assim, a distinção entre provas ilícitas e ilegítimas. Quanto às últimas o vício fica restrito ao momento da introdução da prova no processo."368

\footnotetext{
${ }^{365}$ Guilherme de Souza Nucci, após a reforma de 2008, assim escreveu: "Conforme cremos, o ilícito envolve o ilegalmente colhido (captação da prova ofendendo o direito material, v.g., a escuta telefônica não autorizada) e o ilegitimamente produzido (fornecimento indevido de prova no processo, v.g., a prova da morte da vítima através de simples confissão do réu). Se houver a inversão dos conceitos, aceitando-se que ilicitude é espécie de ilegalidade, então a Constituição estaria vedando somente a prova produzida com infringência às normas de natureza material e não cuidando, por força da natural exclusão, das provas ilegítimas, proibidas por normas processuais, o que se nos afigura incompatível com o espírito desenvolvido em todo o capítulo dos direitos e garantias individuais. A partir da nova redação conferida ao art. 157, caput do CPP, soa-nos nítida a inclusão, no termo maior provas ilícitas, daquelas que forem produzidas ao arrepio das normas constitucionais ou legais. Logo, infringir a norma constitucional ou qualquer lei infraconstitucional (direito material ou processual), pois não fez o referido art. 157 nenhuma distinção, torna a prova ilícita. Este é, pois, o gênero e não a espécie." (Código de Processo Penal comentado. 8. ed. São Paulo: Ed. Revista dos Tribunais, 2008. p. 349-350).

366“Não parece ter sido a melhor opção da Lei 11.690/08, ao definir a prova ilícita como aquela 'obtida em violação a normas constitucionais ou legais' (nova redação do art. $157 \mathrm{CPP}$ ). A falta de distinção entre a infringência da lei material ou processual pode levar a equívocos e confusões, fazendo crer, por exemplo, que a violação de regras processuais implica ilicitude da prova e, em consequência, o seu desentranhamento do processo. O não cumprimento da lei processual leva à nulidade do ato de formação da prova e impõe a sua renovação, nos termos do art. 573, caput, do CPP." (GRINOVER, Ada Pellegrini; FERNANDES, Antonio Scarance; GOMES FILHO, Antonio Magalhães. Nulidades no processo penal. 12. ed., cit., p. 127).

367“Teóricamente la línea de separación es nítida: en la nulidad el defecto es advertido cuando el acto defectuoso ya está insertado en el proceso y en la inadmisibilidad antes que ello ocurra." (CREUS, Carlos. Invalidez de los actos procesales penales, cit., p. 10).

${ }^{368}$ ZILLI, Marcos Alexandre Coelho. O pomar e as pragas. Boletim do IBCCrim, São Paulo, v. 16, n. 188, p. 2-3, jul. 2008.
} 
Por outro ângulo, há quem sustente a manutenção da distinção entre prova ilícita e ilegítima, sob o pretexto de que as primeiras não são passíveis de repetição, enquanto que, quando o vício concerne a um aspecto processual (prova ilegítima), poder-se-ia falar em refazimento do ato. ${ }^{369}$

Conforme ensina BADARÓ, referidos argumentos são insuficientes para impedir uma aproximação entre os institutos. A uma, porque o caráter temporal nem sempre é facilmente distinguível, ao contrário do que inicialmente possa parecer. Nem sempre a ilicitude da prova é anterior à existência do processo. Inclusive, não há óbice, segundo o autor, para que a ilicitude ocorra no próprio processo, durante a produção da prova (ex. tortura em interrogatório judicial). ${ }^{370}$

A duas, porque a renovação do ato não é característica exclusiva da prova ilegítima. Em regra, as provas ilícitas não são refeitas, por um motivo exclusivamente prático. $\mathrm{O}$ vício, em casos de provas ilícitas, normalmente ocorre no momento de obtenção da prova, sendo certo que, havendo o reconhecimento da inadmissibilidade, perde-se o sentido de renovar a prova, pois inexistiria o fator surpresa. Todavia, não há qualquer vedação normativa para que se repita a produção probatória. ${ }^{371}$

Lastreados em tais argumentos, processualistas há que defendem uma identidade maior entre a prova ilícita e o ato nulo. No entendimento de GLOECKNER, a teoria da prova ilícita se enquadraria dentro do gênero nulidade. Sustenta, o autor, a ideia de que a prova ilícita é modalidade de ato processual nulo. O reconhecimento da ilicitude da prova, em si, não oferece critério valorativo algum dos efeitos da realização da prova, sendo imprescindível, para fins de impor a sanção de imprestabilidade, que o magistrado declare nulo o meio de prova. ${ }^{372}$

A interconexão entre os temas da prova ilícita e da teoria das nulidades é evidente, sugerindo ser incorreta a manutenção de estudos - tal como ocorre na maioria dos casos que desconsiderem essa semelhança. Do ponto de vista prático, essa aproximação se revela ainda mais aparente. Deveras, há - ou deveria haver - algum desdobramento processual

\footnotetext{
${ }^{369}$ LOPES JÚNIOR, Aury. Direito processual penal e sua conformidade constitucional, cit., v. 1, p. 578.

${ }^{370}$ BADARÓ, Gustavo Henrique Righi Ivahy. Processo penal, cit., p. 285.

${ }^{371}$ BADARÓ, Gustavo Henrique Righilvahy. Processo penal, cit., p. 285-286. Como exemplo, o autor menciona o elemento de prova obtido por meio de quebra do sigilo bancário. Nesse caso, não haveria o fator surpresa. Sendo reconhecida a ilicitude da quebra, nada impediria que se requeresse nova ordem judicial para obtenção dos dados bancários do imputado.

${ }^{372}$ GLOECKNER, Ricardo Jacobsen. Nulidades no processo penal: introdução principiológica à teoria do ato processual irregular, cit., p. 376 .
} 
discrepante entre, de um lado, a juntada aos autos de um termo de interrogatório produzido por meio de tortura, e, de outro, a juntada de um termo de interrogatório judicial em processo no qual o acusado foi ouvido antes de terminar as oitivas de testemunhas de acusação? Em tese, ao se recorrer à sedimentada concepção acerca do tema, embora ambos retratem exemplos de provas vedadas, o primeiro seria considerado uma prova ilícita, pois vergasta garantia constitucional (art. $5^{\circ}$, III, CF), gerando a sanção de inadmissibilidade, enquanto o segundo representaria prova ilegítima, dado que desobedece legislação processual (art. 400, CPP), devendo o juiz declarar a nulidade do ato. Porém, independentemente da sanção processual imposta, não seriam ambos os elementos de prova contrários à legislação, e, por isso, não deveriam ser inutilizados $?^{373}$

Consoante explica BADARÓ, ainda que se mantenha a tradicional classificação de provas vedadas, torna-se imperioso avançar para uma análise mais pragmática do tema. Nesse sentido, mais relevante do que proceder à distinção entre nulidade e inadmissibilidade, é promover a sanção de "inutilizabilidade" 374 da prova, impedindo a sua valoração. $^{375}$

O ponto nevrálgico da questão, destarte, reside em determinar o que deva ser feito com os elementos probatórios, após o reconhecimento judicial de que estão eivados de vício. Ou seja, cumpre definir como proceder em relação aos vestígios (corpo processual maculado) deixados pela prova ilegítima ou ilícita. Não há de se aceitar, pedindo licença àqueles que porventura discordem de tal posição, uma consequência diversa para a prova obtida em desacordo com normas materiais daquela produzida em afronta à lei processual. Ambas devem ser desentranhadas por força do artigo 157 do Código de Processo Penal.

\footnotetext{
${ }^{373}$ Ensina Gustavo Badaró que "do ponto de vista do material que poderá ser valorado para a formação do (sic) judicial, não terá maiores reflexos a distinção entre a prova ilícita e prova ilegítima, na medida em que, tanto a prova obtida ilicitamente quanto a prova produzida ilegitimamente não poderão ser valoradas pelo juiz. Não se pode negar que as regras sobre admissão e produção da prova têm por escopo último uma correta seleção do material que poderá ser valorado pelo juiz para formação de seu convencimento." (Processo penal, cit., p. 286).

${ }^{374}$ Arturo Capone (L'invalidità nel processo penale, cit., p. 209) ensina que "L'inutilizzabilità, intesa come specie di tratamento, si traduce anzitutto nel divieto per il giudice di porre uma determinata prova a fondamento della decisione; poiché il procedimento probatorio è quel subprocedimento eventuale il cui effetto ultimo consiste appunto nella costituzione del dovere del giudice di valutare la prova, quel divieto in efetti, da un punto di vista formale, altro non sancisce se non l'inefficacia dell'atoo istruttorio."

${ }^{375}$ BADARÓ, Gustavo Henrique Righi Ivahy. Processo penal, cit., p. 287. O Código de Processo Penal italiano prevê a inutilizzabilità das provas produzidas em desacordo com a lei. De forma genérica, a sanção está disposta no artigo 191, do CPP italiano, mas há outros dispositivos legais que tratam de inutilizzabilità, como, por exemplo, o art. 271, que trata das violações durante as interceptações telefônicas. "L'inutilizzabilità colpisce non l'atto in se stesso, bensi il suo valor probatorio. Il giudice d'ufficio, o su richiesta di parte, dichiara che l'atto è inutilizzabile." (TONINI, Paolo. Manuale di procedura penale, cit., p. 204).
} 
Tratando-se de lege ferenda, salutar seria a inserção, em nosso ordenamento, da sanção de inutilizabilidade em relação a determinados meios de prova. Ou seja, em casos como o reconhecimento judicial, nos quais inequivocamente um vício contagiaria o refazimento do ato, correto seria a previsão da inutilizabilidade daquela prova, impedindo uma produção dessa mesma prova no futuro. Porém, enquanto não existente previsão expressa em lei nesse sentido, impõe-se solucionar os casos com o desentranhamento tanto da prova ilícita, quanto da prova ilegítima.

\subsection{O discurso da instrumentalidade e relativização das formas em nome da economia processual: a liberdade disfarçada das formas}

Ao longo do capítulo, analisou-se o atual sistema de nulidades aplicado em nosso país. Consoante se verifica, trata-se de um modelo retrógrado, fundado em conceitos subjetivos, altamente dependentes de uma construção doutrinária que lhe dê interpretação. Para além, a insegurança gerada pelos diversos pronunciamentos judiciais dá a tônica do caos existente sobre o assunto, impedindo que se possa estabelecer quais critérios são utilizados para decidir sobre a possibilidade de convalidação de um ato processual defeituoso. $^{376}$

O motor-propulsor do sistema das nulidades, hodiernamente, reside na concepção de que a forma somente encontra sua razão de existir enquanto esteja assegurando uma finalidade específica. $\mathrm{O}$ ato viciado, por maior que seja seu desvio em relação ao ordenamento penal, desde que o defeito não interfira em seu caráter instrumental, há de ser “perdoado”, já que, em última análise, o que está em jogo é o objetivo da legislação. ${ }^{377}$

DAMASKA entende que esse perdão das formas está diretamente relacionado ao modelo de processo adotado por cada Estado. Com efeito, em países em que há maior centralização do poder nos Estados (“active state”), maior a amplitude discricionária para

\footnotetext{
${ }^{376}$ Pela pertinência, de se citar as palavras de João Conde Correia, o qual exprime a conjuntura atual teoria das nulidades com maestria: "Esta perspectiva apriorística não passa todavia de uma miragem efêmera, que se desvanece numa análise mais profunda e científica, para dar lugar a um mundo de incertezas, dúvidas e contradições; onde o direito positivo, a doutrina e a jurisprudência se entrecruzam, de forma anárquica, num caos quase insuperável. A aparente solidez do sistema desfaz-se num ápice, mostrando uma crise profunda e insuspeitada, reveladora da superficialidade da maioria das reflexões sobre o tema". (Contributo para análise da inexistência e das nulidades processuais penais, cit., p. 13).

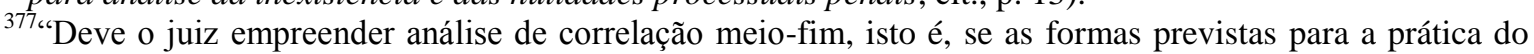
ato, ainda que desrespeitadas, não o impediram de atingir suas finalidades. Segundo professado, esse exame seria meramente objetivo, não se baseando na vontade do sujeito, mas na função do ato dentro do processo." PASSO CABRAL, Antonio do. Nulidades no processo moderno: contraditório, proteção da confiança e validade prima facie dos atos processuais, cit., p. 46.
} 
os magistrados mitigarem as fórmulas impostas pela lei. Segundo o doutrinador, a tendência é que as formas procedimentais, nesses países específicos, sejam consideradas meras "formalidades", as quais não poderiam servir de barreira para uma resolução justa da causa. ${ }^{378}$

No Brasil, defende-se, corriqueiramente, a necessidade de empregar celeridade e eficiência ao processo, afastando, sempre que possível, eventuais óbices aptos a atrapalhar o seu deslinde final. ${ }^{379} \mathrm{E}$ se essas são as verdadeiras bandeiras que hão de ser defendidas, nada mais "contraprodutivo" de que a declaração de nulidade de um ato. Economiza-se, ao máximo, o reconhecimento dos atos nulos, ainda que flagrantemente contrários à legislação, de modo que o processo, conforme a própria etimologia do termo sugere, possa ir adiante. ${ }^{380}$

Não se há de negar que o discurso é sedutor. Aquele que ousasse confrontá-lo, aliás, receberia certamente a pecha de burocrata, tecnocrata, defensor de um processo lento e pouco eficiente. ${ }^{381}$ Dificilmente se encontrará, convenha-se, alguém disposto a sustentar uma teoria das nulidades consubstanciada em um formalismo absoluto, pelo qual sequer um pequeno deslize, por menor que fosse, poderia ser aceito no decorrer do processo.

Indubitável que a mitigação da forma, em prol de um modelo processual mais célere, há de ser buscada sempre que possível, o que corresponde a um avanço em relação ao formalismo excessivo predominante em outras épocas. ${ }^{382}$ A questão, portanto, e por

\footnotetext{
378“"With procedural regulation adapted to the smooth realization of state objectives, officials are given ample elbowroom to act (...) When a particular breach of a procedural provision is nevertheless established, the decision stemming from the breach - if substantively accurate - in not as readily invalidated as it is in the conflict-solving process (...) In the perspective of activist government, such reversal would be mindless 'formalism."' (DAMASKA, Mirjan. The faces of justice, cit., p. 149).

${ }^{379}$ Há quem sustente a inutilidade de algumas formas, propondo, inclusive, a necessidade de, por vezes, desrespeitar as normas legais: "Se a forma não tem explicação teleológica, é destituída de fundamento. Exigir seu cumprimento significa render-se a exigências injustificáveis - o que não se coaduna com a visão moderna do processo. Em relação a elas fala-se em 'violações toleráveis' ou até 'necessárias', visto que o cumprimento dessas regras acaba constituindo óbice aos objetivos visados pelo processo." BEDAQUE, José Roberto dos Santos. Efetividade do processo e técnica processual, cit., p. 426-427.

${ }^{380 ، " A ~ e x i g e ̂ n c i a ~ d e ~ q u e ~ a ~ a t i v i d a d e ~ p r o c e s s u a l ~ s e j a ~ r e a l i z a d a ~ s e g u n d o ~ o s ~ m o d e l o s ~ l e g a i s ~ s o f r e ~ t e m p e r a m e n t o s, ~}$ ditados sobretudo por razões de economia processual; não apenas no processo, mas em todas as atividades, é sempre desejável obter-se o máximo de resultados como o mínimo esforço." GRINOVER, Ada Pellegrini; FERNANDES, Antonio Scarance; GOMES FILHO, Antonio Magalhães. Nulidades no processo penal, 12.ed., cit., p. 31.

${ }^{381}$ No mais das vezes, atribuem à defesa essa característica de ser contrária ao bom andamento do processo: "É triste constatar que o processo penal vem se transformando, nas últimas décadas, num jogo desleal em que a defesa tenta de qualquer maneira anular o processo ou algum ato específico, ávida para que o trâmite do procedimento retorne a fases anteriores." PASSO CABRAL, Antonio do. Nulidades no processo moderno: contraditório, proteção da confiança e validade prima facie dos atos processuais, cit., p. 361.

${ }^{382}$ Para recordar o formalismo extremado no direito romano, válidas são as palavras de Carlos Alberto de Oliveira: "O procedimento, nesse período, apega-se à rigidez e se desenvolve de maneira mecânica e emperrada, tudo dominado por convencional formalismo, ininteligível para o leigo." Do formalismo no processo civil, cit., p. 29.
} 
mais óbvio que possa parecer, é encontrar um equilíbrio entre o rigor da lei e a flexibilização das formas. ${ }^{383}$

Porém, a teoria das nulidades atual, ${ }^{384}$ sobretudo a interpretação jurisprudencial que se faz a partir dela, não tem conseguido estabelecer essa linha mediana. Ao revés, perdura atualmente uma cultura que se poderia chamar de liberdade disfarçada das formas. Nesse sentido, basta observar os princípios reitores da teoria da nulidade (instrumentalidade das formas, convalidação, interesse, etc.) para se chegar à conclusão de que o modelo legal é suscetível aos mais diversos temperamentos, a depender sempre do vício do caso concreto. É evidente que, diante desse cenário, há uma predominância substancial pelo reconhecimento de nulidades relativas, as quais permitem a relativização das formas, em detrimento de um "mero interesse particular". ${ }^{385}$ Daí se poder falar em liberdade das formas.

O disfarce seria justamente o modo como essa flexibilização encontra guarida. Com efeito, por mais que muitos sugiram residir no ordenamento processual o fundamento para essa predominante liberdade das formas, a verdade é que essa tendência não se dá por força de lei. No decorrer dos anos, criou-se uma espécie de verdade doutrinária e jurisprudencial a respeito do tema das nulidades, sobretudo em relação à possibilidade de mitigação das formas, que resultou num mascaramento da genuína razão por detrás da prevalência do desrespeito aos modelos legais. O fundamento para a liberdade das formas, portanto, vem disfarçado de embasamento legal. ${ }^{386}$

\footnotetext{
${ }^{383}$ Achar um meio termo é necessário. Caso contrário, em pouco tempo absolutamente toda forma poderá ser mitigada em nome de um bem maior. Esse perigo não passou despercebido pela doutrina norte-americana: "From those humble beginning, the application of the harmless error doctrine has expanded to the point that we now may consider whether the admission of a confession obtained by government force or coercion is harmless; a destination better left unreached." (WICHT, James Edward. There is no such thing as a harmless constitutional error: returning to a rule of automatic reversal. BYU Journal of Public Law, Indiana, v. 12, n. 73, p. 108, 1997).

${ }^{384}$ Binder, em sua obra, El incumplimiento de las formas procesales, cit., denomina o estudo tradicional das nulidades de "teoria unitária". O processualista argentino faz uma severa crítica a esse modelo, pois compreende que os reflexos do processo civil, e a compreensão unitária (geral) da teoria das nulidades, desvirtuaram a forma da sua verdadeira função.

385،Como se pode constatar, a distinção elaborada pela doutrina e jurisprudência entre nulidades absolutas e relativas é infundada. A referida classificação, além de artificial, permite a cada vez maior ampliação do espectro de incidência das nulidades relativas, como já apontado.” (GLOECKNER, Ricardo Jacobsen. Nulidades no processo penal: introdução principiológica à teoria do ato processual irregular, cit., p. 361).

${ }^{386}$ Vêm a pelo as palavras de Aury Lopes Junior a respeito do posicionamento adotado por alguns magistrados em relação à teoria das nulidades: "Muito preocupante são os juízes que pensam ter um 'compromiso personal con la verdad', muitas vezes guardiões da moral e dos bons costumes, que no fundo, crendo-se do bem (quem nos protege dessa bondade?), não passam de inquisidores. Nada mais fazem do que, com maior ou menor requinte retórico, operar na lógica de que os fins justificam os meios." Direito processual penal e sua conformidade constitucional, cit., v. 2, p. 423.
} 
Por tudo isso, infere-se que o sistema vigente permite um claro menosprezo à forma, a depender sempre do entendimento do juiz. ${ }^{387}$ Uma análise minuciosa dos precedentes autoriza uma conclusão de que inexiste mais uma separação minimamente compreensível entre a nulidade absoluta e nulidade relativa, uma vez que até aos vícios para os quais o legislador, em tese, previu uma insanabilidade, tem-se aceito temperamentos à regra. Há, por assim dizer, um crescente movimento de relativização das nulidades absolutas. ${ }^{388}$

Não fosse somente pela insegurança causada pela confusa teoria das nulidades, seria preciso lembrar que, conforme proposto no primeiro capítulo, o processo tem como função precípua limitar a atividade do Estado. ${ }^{389}$ A forma, nesse contexto, ganha contornos de verdadeiro escudo do acusado (débil) contra eventuais arbitrariedades. ${ }^{390}$

Há de se pensar a teoria das nulidades sob essa ótica, garantindo de fato o due process of law ao acusado, o que, acredita-se, somente ser poderá atingir com a diminuição efetiva dos espaços indevidos para o magistrado decidir conforme a conveniência do caso concreto. Adiante, será visto que, ao mesmo tempo em que a conformação hodierna do princípio do prejuízo constitui uma das responsáveis pela atual crise da teoria das nulidades, reside numa correta concepção dele, especificamente dedicada ao processo penal, a saída para que se inicie um avanço sobre o tema das nulidades.

\footnotetext{
387،“A jurisprudência mudou o quadro das nulidades, considerando absolutas algumas arroladas pela lei como relativos, e vice-versa. É muito arriscado, de antemão, estabelecer uma relação definitiva de nulidades absolutas e relativas, servindo essa, portanto, apenas de orientação.” CAPEZ, Fernando. Curso de processo penal. 6. ed. São Paulo: Saraiva, 2001. p. 641.

${ }^{388}$ A título de exemplo, a despeito de o artigo 564, III, b, do CPP dispor ser nulidade absoluta a ausência de corpo de delito nos crimes que deixam vestígio, não são raros os arestos que consideram o vício sanável: "Penal. Sonegação fiscal. Inépcia da denúncia. Incompatibilidade entre movimentação financeira e renda declarada. Presunção de omissão. Princípio da indivisibilidade. Não aplicação na ação penal pública. Descrição do elemento subjetivo do tipo. Formalidade do ato. Nulidade relativa. Preclusão. Exame de corpo de delito. Prescindibilidade. Observância do princípio do contraditório e da ampla defesa. Crime impossível. Inocorrência. Circunstâncias judiciais desfavoráveis. Fixação regime inicialmente fechado para cumprimento da pena (...) 7. A falta de perícia contábil no crime sonegação não impede o curso da ação penal, se os demonstrativos fiscais e os demais elementos existentes nos autos são suficientes para comprovar a materialidade do delito e a sua autoria, não cabendo se falar em nulidade, ante a ausência de prejuízo, tal como preleciona o art. 563 do CPP." (TRF 2 - Apel. Criminal $4889-2^{\text {a }}$ Turma - rel. Liliane Roriz - j. 11.11.08, p. 21.11.08).

389، Cumpre inicialmente encarar o problema do formalismo-valorativo na perspectiva do poder estatal, envolvendo, assim, a questão dos limites da soberania, pois a organização do processo, um dos seus aspectos mais importantes, implica indubitável restrição à atividade do Estado, nele representado pelo órgão judicial." OLIVEIRA, Carlos Alberto Álvaro de. Do formalismo no processo civil, cit., p. 67.

390، A principal função da forma processual é promover a proteção do imputado. Essa é a ideia central que deverá pautar o exame da violação na atividade persecutória. No que tange à regulação judicial do acusador, este é o local em que a forma deixará de ser garantia de princípio e assumirá condições institucionalizadoras da pretensão acusatória." CARVALHO. Salo de; LOUREIRO, Antonio Tovo. Nulidades no processo penal e Constituição: estudo de casos a partir do referencial garantista. In: PRADO, Geraldo (Org.). Processo penal e democracia. Rio de Janeiro: Lumen Juris, 2009. p. 531.
} 


\section{A REGRA DO PREJUÍZO APLICADA ÀS NULIDADES NO PROCESSO PENAL - ASPECTOS DOGMÁTICOS E A CONFUSA JURISPRUDÊNCIA SOBRE O ASSUNTO}

Analisados, nos capítulos anteriores, os temas relativos à instrumentalidade do processo e ao atual panorama das nulidades, cumpre examinar adiante a matéria específica concernente ao princípio do pas de nullité sans grief. Como já visto, dada a especificidade da função a ser cumprida pelo instrumento-processo penal, é necessário entender as características, e possíveis desvirtuamentos, dessa viga mestre incumbida de conferir um caráter teleológico ao ato processual.

Com vistas a cumprir esse desiderato, o presente capítulo tratará, inicialmente, de lançar luzes sobre a origem do pas de nullité sans grief, de modo a compreender a razão inicial de sua utilização. Em seguida, serão examinados os principais aspectos dogmáticos da regra em questão, e as diversas interpretações de seu significado dadas pelas cortes brasileiras.

\subsection{Origem do pas de nullité sans grief e seu desenvolvimento histórico no Brasil}

Tarefa nada simples é traçar com exatidão as origens da regra do prejuízo. Para além da complexidade de se estabelecer um marco introdutório claro no Direito, ${ }^{391}$ é também verdade que no decorrer dos anos a própria concepção do pas de nullité sans grief foi perdendo seu sentido original.

\footnotetext{
${ }^{391}$ A demonstrar a dificuldade de definir com precisão a origem do pas de nullité sans grief, há de se registrar os diferentes pontos de vista históricos da doutrina. Afirmando encontrar raízes no Código Napoleônico: "Trata-se de um princípio cujos contornos remontam ao processo penal francês, justamente no processo de instituição do Código Napoleônico.” (GLOECKNER, Ricardo Jacobsen. Nulidades no processo penal: introdução principiológica à teoria do ato processual irregular, cit., p. 247). Entendendo que a origem remonta à Ordenação de Tolosa: “Compreendendo a extensão destes malefícios, surgiu já em 1667, com a ordenação de Tolosa, um primeiro protesto contra a outranae, expresso na máxima: 'pas de nullité sans grief’, não há nulidade quando não há prejuízo (ROSA, Inocencio Borges da. Nulidades no processo. Porto Alegre: Livraria do Globo, 1935. p. 128-129). Nesse mesmo sentido (MOSSIN, Heráclito Antonio. Nulidades no direito processual penal. São Paulo: Atlas, 1998. p. 18): "Deve-se abrir parênteses para fazer alusão ao histórico pas de nullité sans grief, que surgiu com a Ordenação de Tolosa". Há, no entanto, quem entenda que a necessidade de se identificar o prejuízo para reconhecimento da nulidade nasceu de uma construção pretoriana no século XIX: "De célèbres maximes sont par ailleurs nées de la reprise d'une jurisprudence d'Ancient droit. C'est le cas du pas de nullité sans texte et sans grief. Au XIXème siecle, la jurisprudence créé encore des adages." (PIERRE-MAURICE, Sylvie. Le Code de Procédure Civile et les maximes. Revue Scientia Juris, n. 2, 2013).
} 
Na realidade, o estudo histórico da ideia de instrumentalidade das formas confundese com a própria noção e evolução do formalismo no âmbito procedimental. ${ }^{392}$ Há de se compreender que a construção de fórmulas aptas a temperar um processo rígido incluindo, aqui, o princípio do prejuízo - nasce como imposição decorrente do dinamismo da sociedade. No escólio de GUILHERME MADEIRA DEZEM, “a velocidade das mudanças que ocorrem na sociedade e o aumento da complexidade nas circunstâncias do processo criam situações em que o modelo legal previsto não responde a estas peculiaridades de maneira satisfatória. Surge, então, a necessidade de flexibilização.”393

Havia um tempo em que o mínimo deslize da forma, por mais insignificante que fosse, maculava o processo. ${ }^{394}$ É que, à época, o formalismo estava atrelado, inclusive no Direito Romano ${ }^{395}$, ao misticismo, ao místico, decorrendo daí que o defeito processual significava na realidade o desrespeito à vontade dos deuses. ${ }^{396}$

Essa visão hermética e formalista do ato processual tornou-se conhecida como sistema formular. ${ }^{397}$ De acordo com esse modelo, na medida em que o processo prevê uma determinada maneira para execução do ato, é ela considerada uma fórmula cujos contornos devem ser minuciosamente observados pelos magistrados, sob pena de se repetir todo o procedimento em razão do vício ocorrido. Inexiste, nesse contexto, qualquer critério teleológico para avaliação da repercussão do ato defeituoso; a declaração da nulidade, destarte, constituía consequência automática e inafastável em face dos mais insignificantes erros processuais. $^{398}$

\footnotetext{
392،QQuanto mais recuarmos no tempo, mais o processo penal se apresenta como um direito formalista e rígido nas consequências da violação desse formalismo." (CONDE CORREIA, João. Contributo para análise da inexistência e das nulidades processuais penais, cit., p. 31).

${ }^{393}$ DEZEM, Guilherme Madeira. A flexibilização no processo penal. 2013. Tese (Doutorado) - Faculdade de Direito da Universidade de São Paulo, São Paulo, 2013. p. 41.

${ }^{394}$ Cumpre esclarecer que a palavra processo deve ser entendida, no contexto, sem qualquer caráter técnicoterminológico. Com base nos ensinamentos de Bedaque (Direito e processo: influencia do direito material sobre o processo, p. 32) "até meados do século XIX, o direito processual inexistia como ciência. A ação era considerada um aspecto do direito material, ou um direito nascido da sua violação."

395“Come è noto, nel diritto romano piú arcaico l'atto privo di qualcuno dei requisiti necessari era di regola considerato giuridicamente irrilevante." (CAPONE, Arturo. L'invalidità nel processo penale, cit., p. 1).

${ }^{396}$ Carlos Alberto Alvaro de Oliveira (Do formalismo no processo civil, cit., p. 17) discorre sobre o formalismo no Direito Romano: "De ponta a ponta imperam os ritos, os juramentos e os sacrifícios. E a sentença, apesar disso, é pronunciada depois de uma série de formalidades sem qualquer relação, do ponto de vista racional, com a questão a ser resolvida. Tudo, portanto, desenvolve-se sobre um plano inteiramente místico."

${ }^{397}$ Há quem o denomine de sistema de sanção do erro literal das formas (GLOECKNER, Ricardo Jacobsen. Nulidades no processo penal: introdução principiológica à teoria do ato processual irregular, cit., p. 242).

${ }^{398} \mathrm{Em}$ um momento histórico diverso, mas apenas para ilustrar a rigidez a que se pode chegar um modelo formular, há registros de que nos EUA houve o reconhecimento da nulidade de um processo em que o juiz alegou que o crime fora cometido "against the peace and dignity of state", em vez de "against the peace and dignity of the state." (State v. Campbell, 109 S.W. 706, 707).
} 
Consta que a primeira oportunidade em que a questão do prejuízo foi suscitada para aquilatar a existência de uma nulidade ocorreu justamente como reação necessária a esse formalismo exacerbado. Com efeito, a Ordonnance francesa de 1667, de Luiz XIV, estabelecia que o único intérprete da lei era o próprio rei, vedando aos Parlamentos ${ }^{399}$ qualquer exercício de interpretação da norma. ${ }^{400}$ Considerando a época de pleno absolutismo, a nulidade constituía um instrumento empregado pelo rei para assegurar que os juízes cumprissem rigorosamente a letra da lei, impedindo que a discricionariedade dos magistrados se sobrepusesse à vontade do soberano. ${ }^{401}$

É justamente sob a égide da Ordonnance, e em contrariedade a seus dispositivos, que o Parlamento de Toulouse introduziu em um julgado, posteriormente repetido outras vezes por esse mesmo tribunal, um critério mediante o qual os magistrados se abstinham de declarar a ineficácia de um ato, em virtude de não vislumbrarem prejuízo algum às partes. Nascia aí o nullité sans grief n'opere rien, como forma de irresignação dos juízes em relação a um ordenamento que impedia todo e qualquer traço subjetivo no processo decisório. ${ }^{402}$

A real mudança no tratamento conferido aos atos processuais, distanciando-se da ideia do Rei como único intérprete da lei, se deu com o advento do Code de Procedure Civile napoleônico, de 1806, o qual foi elaborado justamente para quebrar a antiga ordem jurídica, privilegiando a simplicidade, a publicidade e a oralidade dos julgamentos, deixando de lado, por seu turno, formalidades inúteis. ${ }^{403}$ No campo das nulidades, se observa um notável avanço em relação à Ordonnance, tendo em vista que pela primeira

\footnotetext{
${ }^{399}$ Há de se lembrar que os Parlamentos, no ancien régime, exerciam o papel de tribunais de justiça.

${ }^{400}$ Apesar do aspecto formalista da lei, Calamandrei lembra que "particular importancia tuvieron las Ordenanzas del Rey de Francia, y más que todas la Ordonnance Civile, de Luis XIV, de 1667, las cuales quisieron regular de un modo claro, preciso y simple el aspecto exterior y formal del procedimiento." (LIEBMAN, Enrico Tulio. Manual de derecho procesal civil. Trad. Santiago Sentis Melendo. Buenos Aires: EJEA, 1955. p. 31-32).

${ }^{401}$ CAVANI BRAIN, Renzo. Nulidad e forma en el proceso civil: perspectiva histórica de la función de la nulidad procesal en su camino hacia el modelo de la finalidad. Derecho \& Sociedad, n. 38, p. 215, 2012.

${ }^{402}$ BORDEAUX, Raymond. Philosophie de la procédure civile: mémoire sur la réformation de la justice. Évreux: Imprimerie de Auguste Hérissey, 1857. p. 384.

${ }^{403} \mathrm{O}$ advento da Revolução Francesa e o movimento codificador que assolou a Europa no século XIX trouxeram, pela primeira vez, uma tentativa de regulamentação geral da matéria de nulidades. O que até aquela época era deixado à mera casuística, sem qualquer preocupação terminológica própria, passou a receber estudos específicos, influenciados pelas concepções jusracionalistas, surgindo pela primeira vez o que poderia ser denominado de uma teoria das nulidades. (CONDE CORREIA, João. Contributo para análise da inexistência e das nulidades processuais penais, cit., p. 37).
} 
vez pôde ser notada uma preocupação com o conteúdo da forma, superando o adágio prevalecente até então segundo o qual la forme emport le fond. ${ }^{404}$

Com efeito, no lugar da declaração de nulidade como consequência dos mais insignificantes dos desvios, o Código Napoleônico passou a prever que somente seriam considerados ineficazes os defeitos para os quais a lei cominasse pena de nulidade. ${ }^{405}$ Todavia, conquanto presente um avanço significativo no combate ao formalismo excessivo, o Code, como forma de se proteger de decisões arbitrárias do Parlamento, não permitia espaço para discricionariedade do magistrado em matéria de nulidade. Muito embora a doutrina e jurisprudência da época tenham construído alguns institutos que ajudaram no desenvolvimento da teoria das nulidades - inclusive com a distinção entre formalidades necessárias e formalidades acidentais -, é certo que o direito posto não comportava espaço para avaliações subjetivas em matéria de nulidades.

Em verdade, consta que a primeira legislação na qual o prejuízo fora inserido como instrumento para avaliação da nulidade é a pouco estudada Lei de Processo Civil de Cantão de Genebra, datada de 1819. Sob o comando de Pierre François Bellot, referido diploma modifica a tradicional posição passiva do juiz - característica do sistema francês - e outorga-lhe um papel ativo, inclusive para investigar os fatos apurados no processo. ${ }^{406}$

Nesse sentido, ainda, mencionada lei suíça não impedia o magistrado de declarar com base em um rol taxativo; ao revés, conferia ao juiz a possibilidade de encontrar um equilíbrio entre a preservação das garantias previstas na lei e a necessidade de não se prender ao culto supersticioso das formas. A nulidade, portanto, somente poderia ser declarada se fosse a única maneira de reparar o prejuízo sofrido pela parte que a requeresse. Tal sistema legal constituiu um genuíno avanço para seu tempo, conferindo ao instituto da nulidade um papel de reparação processual de um prejuízo sofrido por uma das

\footnotetext{
${ }^{404}$ Como exemplo ilustrativo dessa nova visão, há de se citar o artigo 173 do Code, que previa que "as nulidades do processo serão sanadas se não forem suscitadas pelas partes salvo nos casos de incompetência."

${ }^{405}$ Cf. CAVANI BRAIN, Renzo. Nulidad e forma en el proceso civil: perspectiva histórica de la función de la nulidad procesal en su camino hacia el modelo de la finalidad, cit., p. 226. "La idea general que no se podía pronunciar otras nulidades que aquellas expresamente previstas en la ley, proveniente del esfuerzo de racionalización de las prácticas judiciales, que culmina en los Códigos de Napoleón y sus centralismo del Estado, pronto demostró ser un proyecto político difícil de sostener." (BINDER, Alberto. El incumplimiento de las formas procesales, cit., p. 26).

${ }^{406}$ OLIVEIRA, Carlos Alberto Álvaro de. Do formalismo no processo civil, cit., p. 100.
} 
partes, afastando-o daquela função meramente sancionatória decorrente dos mais banais deslizes de forma. ${ }^{407}$

A partir dessa previsão normativa, outros ordenamentos europeus passaram a tratar da necessidade de existência do prejuízo para decretação da nulidade. ${ }^{408}$ Importante destacar, contudo, que essa percepção de que o ato nulo deve pressupor também um prejuízo às partes se deu incialmente no campo do processo civil, sendo certo que apenas posteriormente foi transportado para a seara penal.

Entre nós, o modelo francês teve enorme influência no tema das nulidades. Consoante ensina MossıM, “embora as Ordenações tenham tido grande influência na legislação do início da República, a verdade é que, em termos de nulidade, o legislador republicano não seguiu os passos da legislação reinol, mas sim buscou inspiração na legislação francesa, que se tornou responsável pela edificação desse importantíssimo instituto da legislação brasileira, que por sinal é bastante complexo e falho." ${ }^{409}$

O Código de Processo Penal de 1832, alcunhado de Código do Império, revelou essa influência francesa ao tratar das formalidades substanciais do processo, em contraposição às formalidades acidentais. Embora não houvesse distinção expressa entre as duas espécies de formalidade, a leitura do diploma legal da época permite inferir que apenas seriam considerados nulos os atos praticados em desobediência às fórmulas substanciais do processo. ${ }^{410}$

Registre-se, ainda, que aludida legislação não utilizava o termo nulidade, sendo certo que eventuais erros levados a efeito durante o julgamento eram tratados no capítulo de recursos. Julgado procedente o recurso que pleiteasse a declaração de inobservância das formalidades substanciais, tornar-se-ia necessário a formação de outro processo, cujo julgamento dar-se-ia por novo corpo de jurados. ${ }^{411}$

\footnotetext{
${ }^{407}$ CAVANI BRAIN, Renzo. Nulidad e forma en el proceso civil: perspectiva histórica de la función de la nulidad procesal en su camino hacia el modelo de la finalidad, cit., p. 228.

${ }^{408}$ Além da França, país no qual nasceu propriamente o pas de nullité sans grief (ainda que como critério interpretativo do Parlamento), há de se citar a legislação italiana do século XIX, a qual foi fortemente influenciada pelo próprio Direito francês. "Il fenômeno si presentava come il prodotto del retroterra culturale della codificazione napoleônica, le cui influenze contenutistiche tracciarano le linee degli orientamenti giurispurdenziale inerenti all'ambito aplicativo del rimedio sanzionatorio nel codice di procedura penale del 1865." (IASEVOLI, Clelia. La nullità nel sistema processuale penale. Napoli: Cedam, 2008. p. 146).

${ }^{409}$ MOSSIN, Heráclito Antonio. Nulidades no direito processual penal, cit., p. 11.

${ }^{410}$ FERNANDES, Paulo Sergio Leite. Nulidades no processo penal, cit., p. 14.

411،A Art. 302: Julgando-se na Relação procedente o recurso por se não terem guardado as formulas prescriptas, formar-se-há novo processo na subsequente sessão com outros Jurados, remettendo-se para esse fim, os autos ex-officio ao Juiz de Direito, quando a accusação tiver sido por officio do Promotor; e entregando-se à parte interessada, quando fôr particular."
} 
O Código de Processo do Império, entretanto, não enfrentou a questão do prejuízo no tocante às nulidades. $\mathrm{O}$ mero desrespeito às formalidades substanciais era suficiente para se determinar novo julgamento. Com isso, e considerando a referida indefinição do que consistiria uma formalidade substancial no âmbito do processo, ${ }^{412}$ criou-se genuína confusão no tratamento da matéria, verificando-se que os magistrados, ao longo do tempo, passaram a utilizar uma lista de possíveis causas de nulidade, elaborada pela doutrina, para facilitar o processo decisório. ${ }^{413}$

O século XIX também não revelou grandes avanços legislativos, ${ }^{414}$ cumprindo observar que o tema das nulidades foi deixado de lado (intocado), ao contrário do que ocorria com a maioria das legislações europeias, já preocupadas, à época, com o caráter instrumental das formas. Dessa forma, havia uma insegurança jurídica patente em relação aos atos que poderiam ser revistos por recurso, permitindo que as partes, sabedoras da característica formalista da maioria dos juízes, se preocupassem mais com os meios (por vezes ardilosos) de anular o processo do que com a discussão do mérito da causa.

A ideia do prejuízo, relacionada ao tema das nulidades processuais penais, somente foi inserida em nosso sistema com os denominados Códigos Estaduais. Como é cediço, com o advento da Constituição de 1891, legislar sobre processo da Justiça Federal competia somente ao Congresso Nacional, porém o constituinte autorizava a cada Estadomembro a elaboração de seu próprio Código de Processo Penal. ${ }^{415}$

Influenciados pelo direito francês, bem como pelo Regulamento $\mathrm{n}^{\mathrm{o}} 737$, utilizado por muito tempo como um genuíno Código de Processo Civil do Brasil, ${ }^{416}$ alguns Códigos

\footnotetext{
${ }^{412}$ Aqui vêm a calhar as palavras do Desembargador Olegário Herculano de Aquino e Castro, citadas por MOSSIN (Nulidades no direito processual penal, cit., p. 14): "O Código do processo, no citado artigo, restringe recurso das partes aos casos que menciona; esquece-se, porém, de definir as fórmulas que considera substanciais, e daí provém a variedade e incoerência que de ordinário se observa da apreciação e julgamento das nulidades no processo."

${ }^{413}$ LEITE FERNANDES (Nulidades no processo penal, cit., p. 14) lembra que, em 1870, a doutrina havia identificado cerca de 120 nulidades. Em 1924, já se falava na existência de 624 nulidades.

${ }^{414}$ Embora haja um inquestionável subjetivismo no termo avanço, não se pode olvidar que a Lei $\mathrm{n}^{\circ} 261$ ficou marcada por seus termos conservadores. Como observa Gustavo Badaró (A garantia do juiz natural no processo penal, cit., p. 124) “a Lei n ${ }^{\circ} 261$, de 3 de dezembro de 1841, e o Regulamento no 120 , de 31 de janeiro de 1842, suprimiram o júri de acusação e deram às autoridades policiais a atribuição de formar a culpa e pronunciar ou impronunciar os acusados sem, contudo, dar aos delegados e subdelegados independência ou estabilidade no cargo, mas ao contrário, obrigando-os a aceitar a nomeação, sem receber vencimento algum, além de serem demissíveis ad nutum. Ou seja a atividade da polícia, confiada aos delegados e subdelegados, além das funções de polícia administrativa e polícia judiciária, também incluía atividade judiciária propriamente dita."

${ }^{415}$ SOUZA, José Barcelos de. Direito processual civil e penal. Rio de Janeiro: Forense, 1995. p. 81.

${ }^{416}$ Importa lembrar que o Regulamento $\mathrm{n}^{\circ} 737$, inicialmente criado para disciplinar o processo das causas comerciais, foi adotado como Código de Processo Civil com o Decreto $n^{\circ} 763$, de 1890 . Em seu artigo 677, $\S 1^{\circ}$, referido diploma legal já esboçava um princípio do prejuízo ao reger que "as nullidades arguidas não
} 
de Processo Penal Estaduais dispuseram sobre a obrigação de verificação de um prejuízo efetivo a uma das partes como condicionante para declaração da nulidade. ${ }^{417}$ A título ilustrativo, de se consignar os termos do artigo 327, g, do Código de Processo Penal do Rio Grande do Sul: “Constituem nulidades insanáveis a preterição de alguma fórmula ou termo do processo, em prejuízo da acusação ou da defesa." $" 118$

Vale ressaltar que esse duplo critério para aplicação das nulidades, com a previsão, de um lado, da ainda incipiente fórmula do pas de nullité sans grief em determinadas legislações estaduais e, de outro, com um Código de Processo Penal (cuidando de matérias federais) desprovido de qualquer dispositivo nesse sentido, acabou porgerar uma jurisprudência caótica no início do século XX. Na lição de GALDINO SIQUEIRA, em obra publicada em 1917, “a versatilidade e falta absoluta de orientação dos julgados dos nossos tribunais, ora erigindo em nulidade simples irregularidades de formas, ora deixando de pronunciar nulidades manifestas, incertezas que só têm contribuído para o descrédito cada vez maior da nossa magistratura, e o sacrifício da Justiça, que concretiza os próprios interesses sociais."

O tratamento unitário da matéria de nulidades somente foi retomado com a decretação do Código de Processo Penal de $1941 .{ }^{420}$ De notória inspiração no Código Rocco italiano, o atual diploma processual penal imprime de vez a visão teleológica do ato processual, aplicando-se a nulidade apenas nos casos em que o defeito resulte em prejuízo

sendo supridas ou pronunciadas pelo Juiz, importam a anulação do processo na parte respectiva, si ellas causaram prejuízo áquelle que as arguiu."

${ }^{417}$ Sobre a origem e evolução da história do prejuízo no processo civil, Calmon de Passos (Esboço de uma teoria das nulidades aplicadas às nulidades processuais, cit., p. 131) explica: "o princípio da inexistência da nulidade não havendo prejuízo é antigo, inclusive entre nós. Já era conteúdo do art. 1.359 do Código de Processo da Bahia e dos que o acompanharam, inspirados, provavelmente, no código do Cantão de Genebra que, no seu art. 745, determinava, entre outros casos, apenas ser possível a decretação da nulidade de um ato do processo quando a violação da forma houvesse causado à parte contrária prejuízo, que só com a anulação fosse possível de ser reparado, dispositivo igualmente inserido no projeto Orlando-Mortara, na Itália. Também na França, o decreto-lei de 30 de outubro de 1935 estendeu a todos os atos processuais princípio inicialmente restrito aos exploits d'ajournement'e aos 'actes d'appel', qual o da inexistência de nulidade sem prejuízo para parte contrária."

${ }^{418}$ De forma semelhante, o Código de Processo Penal de Minas Gerais (art. 476, parágrafo único) assim assentava: "Outrossim, [a nulidade] não pode ser pronunciada quando não houver prejuízo de nenhuma das partes, ou quando a falha tiver sido suprida proveitosamente no correr da ação”. Sobre o dispositivo legal em questão, mormente na categoria do prejuízo, João de Oliveira Filho (Código do Processo Penal de Minas Gerais. São Paulo: Casa Duprat, 1927. p. 388) assevera "o prejuízo da parte pode se referir tanto à acusação, como à defesa, isto é, si ficou impossibilitada de promover alguma prova, alguma diligencia, algum recurso, etc. Este prejuízo não é pecuniário em relação às custas, etc."

${ }^{419}$ SIQUEIRA, Galdino. Curso de processo criminal, cit., p. 417.

${ }^{420}$ Havia, no antigo Código de Processo Penal italiano (1930), previsão representando o princípio da instrumentalidade das formas: "La nullità di um atto è sanata, se, nonostante l'irregolarità, l'atto ha egualmente conseguito il suo scopo rispetto a tutti gli interessati." 
para a acusação ou à defesa, ${ }^{421}$ bem como nas hipóteses em que o ato influa na apuração da verdade substancial ou na decisão da causa. ${ }^{422}$

Conforme se infere, portanto, a evolução da matéria das nulidades está intimamente relacionada com a criação de critérios legais para combater o excesso de formalismo. Se em priscas eras a forma garantia ao soberano o controle absoluto do procedimento penal, esse modelo foi gradativamente abandonado, permitindo o surgimento de mecanismos aptos a conferir uma dimensão instrumental aos atos processuais. É por isso que a exigência de um efetivo prejuízo no âmbito das nulidades vai ao encontro da atual tendência da grande maioria das legislações, representando hodiernamente o que DINAMARCO denominou de terceiro momento metodológico do direito processual. ${ }^{423}$

\subsection{Instrumentalidade das formas e a regra do pas de nullité sans grief: necessária dissociação das ideias e a inexistência de um princípio-mestre em matéria de nulidades}

Antes de se partir para discussões mais aprofundadas a respeito do instituto do prejuízo nas nulidades, imprescindível consignar breves palavras em relação à natureza jurídica do pas de nullité sans grief. O entendimento doutrinário e a jurisprudência, quase à unanimidade, utilizam como sinônimos a instrumentalidade das formas e o prejuízo, classificando ambos, no mais das vezes, como princípios. ${ }^{424}$ Porém, há de se indagar: existe uma identidade absoluta entre a instrumentalidade das formas e a exigência do prejuízo? E mais: a necessidade, para reconhecimento da nulidade, de se vislumbrar um prejuízo às partes configura, per se, um princípio?

Conforme já discutido no primeiro capítulo, a forma não pode ser um fim em si mesma; consubstancia, em verdade, meio para que o ato processual atinja seus objetivos. Eis, portanto, a definição da instrumentalidade das formas, ideia que de fato deve orientar a

\footnotetext{
${ }^{421}$ Art. 563, CPP.

${ }^{422}$ Art. 566, CPP.

${ }^{423}$ “Com tudo isso, chegou o terceiro momento metodológico do direito processual, caracterizado pela consciência da instrumentalidade como importantíssimo polo de irradiação de ideias e coordenador de diversos institutos, princípios e soluções." (DINAMARCO, Candido Rangel. A instrumentalidade do processo, cit., p. 22).

${ }^{424}$ “No Brasil, tal princípio [do prejuízo] também é conhecido como 'instrumentalidade das formas', de acordo com o qual a declaração de nulidade apenas poderá ser realizada se o ato processual, mesmo praticado com inobservância de algum requisito, não atingir a finalidade a que se destinara". (GLOECKNER, Ricardo Jacobsen. Nulidades no processo penal: introdução principiológica à teoria do ato processual irregular, cit., p. 247). Nesse mesmo sentido, BADARÓ, Gustavo Henrique Righi Ivahy. Processo penal, cit., p. 577.
} 
matéria das nulidades. É preciso, contudo, refletir sobre a essência da instrumentalidade das formas, sua estrutura e seu papel no ordenamento penal. Trata-se de um princípio? Para tanto, forçoso recorrer, ainda que superficialmente, ao estudo da teoria dos princípios. ${ }^{425}$

Na lição de ALEXY, ${ }^{426}$ norma é gênero, do qual são espécies regras e princípios. Em síntese, princípios seriam mandamentos de otimização, os quais são caracterizados por poderem ser satisfeitos em graus variados e por terem a medida devida de sua satisfação dependente não somente das possibilidades fáticas, mas também das possibilidades jurídicas. Um princípio será realizado dentro da maior extensão possível, mas seu limite de aplicação será determinado por outros princípios e regras colidentes.

Regras, por outro lado, ainda segundo o escólio do jus-filósofo alemão, constituem normas que ou são cumpridas, ou não. Diferentemente do que ocorre com os princípios, normas podem ser simplesmente caracterizadas por um "tudo ou nada" ("all or nothing ${ }^{927}$ ). Há de se fazer o que ela exige; nem mais, nem menos. ${ }^{428}$ A regra somente pode ser inobservada se considerada inválida dentro do ordenamento jurídico. Sendo ela válida, seu cumprimento é obrigatório. ${ }^{429}$

À vista desses conceitos, pode parecer razoável que se confira à instrumentalidade das formas status de princípio. Afinal, ao se assentar que a nulidade não será declarada nas hipóteses em que o ato atingir seu escopo, parece crível a suposição de que se estaria aqui diante de um mandamento de otimização. Isto é, dentro da máxima extensão possível, mas limitado a regras e princípios colidentes, essa ideia regulativa ${ }^{430}$ deveria ser cumprida.

De fato, sob o aspecto da estrutura da norma, poder-se-ia classificar a instrumentalidade das formas como princípio. Mas de onde se extrai tal princípio, dado que

\footnotetext{
${ }^{425}$ Esclareça-se, desde já, que não se pretende aqui discutir em profundidade as inúmeras posições sobre a teoria dos princípios, uma vez que referida pesquisa, para além de exigir uma dissertação própria, se revela desnecessária para o objeto do presente trabalho. Opta-se por utilizar, como base, o estudo desenvolvido por Alexy (Teoria dos direitos fundamentais. 2. ed. Trad. Virgilio Afonso da Silva. São Paulo: Malheiros Ed., 2012) por se tratar de pesquisa conhecida e bem disseminada em nosso país.

${ }^{426}$ ALEXY, Robert. Teoria dos direitos fundamentais, cit., p. 90.

${ }^{427}$ DWORKIN, Ronald. Taking rights seriously. 6. ed. London: Duckworth, 1991.

${ }^{428}$ DWORKIN, Ronald. Taking rights seriously, cit., p. 91.

${ }^{429}$ “O principal traço distintivo entre regras e princípios, segundo a teoria dos princípios, é a estrutura dos direitos que essas normas garantem. Nos casos de regras, garantem-se direitos (ou se impõem deveres) definitivos, ao passo que no caso dos princípios são garantidos direitos (ou são impostos deveres) prima facie." (SILVA, Luís Virgílio Afonso da. Direitos fundamentais: conteúdo essencial, restrições e eficácia. São Paulo: Malheiros Ed., 2009. p. 45).

${ }^{430}$ SILVA, Luís Virgílio Afonso da. Direitos fundamentais: conteúdo essencial, restrições e eficácia, cit., p. 46.
} 
no processo penal, ao contrário do que se passa no civil (art. 244, CPC) ${ }^{431}$, inexiste uma disposição normativa representando essa norma-diretriz? Esclareça-se que não se está a afirmar que todo e qualquer princípio de direito deva necessariamente ser retirado de norma escrita. ${ }^{432}$ Porém, se há de convir que é perigoso atribuir natureza de princípio a uma ideia - e aplicá-la como tal -, sem qualquer desvelo acerca da origem ou dos elementos que o constituem.

A grande confusão advém da própria doutrina - hodiernamente repetida à exaustão pela jurisprudência. Tornou-se quase lugar-comum afirmar que o princípio da instrumentalidade das formas teria o mesmo significado que o "princípio" do prejuízo (pas de nullité sans grief). Dessa forma, asseverar que a nulidade somente será declarada se o ato atingir sua finalidade teria o mesmo significado que afirmar que não seria imposta a nulidade quando inexistente o prejuízo. ${ }^{433}$ Ambas as ideias estariam resumidas no artigo 563 do Código de Processo Penal, positivando, assim, a instrumentalidade das formas do processo.

Não parece ser esse o entendimento mais correto. À luz das definições já lançadas supra, e esse ponto há de restar claro, não se concebe um "princípio" do prejuízo. Quando o artigo 563 do CPP, ao reger que o ato, ainda que defeituoso, não será declarado nulo se dele não advier um prejuízo, não está entabulando um princípio na legislação pátria. Muito ao revés, está ali estruturando uma obrigação de forma definitiva; portanto, uma regra. Ou bem haverá o prejuízo e, consequentemente, será reconhecida a nulidade, ou não se vislumbrará um dano às partes, e o ato não será anulado. Eis, aí, uma representação manifesta da fórmula de DwORKIN, "all or nothing". 434

\footnotetext{
${ }^{431}$ Artigo 244, CPC: "Quando a lei prescrever determinada forma, sem cominação de nulidade, o juiz considerará válido o ato se, realizado de outro modo, lhe alcançar a finalidade."

${ }^{432}$ Conforme adverte Humberto Ávila (Teoria dos princípios: da definição à qualificação dos princípios jurídicos. 3. ed. São Paulo, 2004) "O importante é que não existe correspondência entre norma e dispositivo, no sentido de que sempre que houver um dispositivo haverá uma norma, ou sempre que houver uma norma deverá haver um dispositivo que lhe sirva de suporte. Em alguns casos há norma, ou sempre que houver uma norma deverá haver um dispositivo que lhe sirva de suporte."

433، $\mathrm{O}$ fim do ato nada teria que ver com o prejuízo da parte, nem este com aquele. Poder-se-ia alcançar o fim a que o ato se destinava e haver prejuízo, ou vice-versa, não se alcançar o fim posto pela lei ao ato e não ocorrer o prejuízo." (Esboço de uma teoria das nulidades aplicadas às nulidades processuais, cit., p. 132). Embora Calmon de Passos não concorde com a afirmação, pois mais à frente em sua obra a negue, torna-se válida a citação, pois vai ao encontro daquilo que foi sugerido no texto acima.

${ }^{434}$ Sobre a estrutura normativa de regras, ensina Mauricio Zanoide de Moraes (Presunção de inocência no processo penal brasileiro: análise de uma estrutura normativa para a elaboração legislativa e para a decisão judicial, cit., p. 271): “A norma-regra é aplicada como está prevista, ou não é aplicada, é a fórmula do 'tudo ou nada' ('all or nothing') de aplicação. Não poderá ser em parte afastada e em parte aplicada. Os direitos/deveres garantidos mediante regras, diferente do que ocorre com os princípios, não são suscetíveis de ponderação com outras normas a fim de que sejam, em determinados casos, afastados em parte e em outra parte produzam efeitos jurídicos."
} 
Com efeito, inexistem regras ou princípios que limitem (no sentido de dar maior restrição) a necessidade de haver prejuízo para reconhecimento da nulidade. Digna de crítica, ou não, a legislação em vigor (válida que é) determina que sem prejuízo, não há nulidade. E justamente por ser uma norma-regra, inadmissível a tese, defendida por alguns, ${ }^{435}$ de que nas hipóteses de nulidades absolutas seria desnecessária a verificação de um prejuízo. Conforme será detalhadamente examinado adiante neste capítulo, a chave para diferenciação das nulidades não se encontra na necessidade ou não do prejuízo, mas, sim, naquilo que configure de fato um prejuízo e o standard probatório exigido para cada caso.

Retomando o ponto fulcral a ser discutido, o pas de nullité sans grief constitui uma norma-regra em nosso ordenamento e não se confunde com um princípio. É preciso, nesse sentido, dissociar a ideia da necessidade do prejuízo para reconhecimento da nulidade da ideia de um pensamento diretivo ${ }^{436}$ apto a se espraiar por toda a matéria de nulidade.

A problemática envolvendo esse equívoco, qual seja, o de tachar a exigência do prejuízo como um "princípio" das nulidades vai muito além da mera nomenclatura. Ocorre que, não raras vezes, as decisões judiciais deixam de reconhecer um vício patente em homenagem a um suposto "princípio do prejuízo". Tal "princípio", que hipoteticamente se colocaria em grau hierárquico superior a qualquer regra, pois promoveria uma diretriz-mãe para a matéria das nulidades, seria apto a justificar os mais graves defeitos processuais, apenas com o desgastado argumento de que "a parte não demonstrou o prejuízo."437

Afora isso, o propalado "princípio" do prejuízo é diversas vezes colocado em pé de igualdade com garantias constitucionais, tais como a ampla defesa e o devido processo legal. Com base nesse entendimento, são iterativas as decisões judiciais em que, mesmo diante de flagrante desrespeito aos direitos fundamentais do acusado, o magistrado simule

\footnotetext{
${ }^{435}$ Por todos, Heráclito Antonio Mossin (Nulidades no direito processual penal, cit., p. 9): "Por oportuno, deve-se deixar aclarado, desde logo, que, se a nulidade for absoluta, não há como cogitar de eventual prejuízo, uma vez que, in casu, este é presumido."

${ }^{436}$ Termo empregado por Humberto Ávila (Teoria dos princípios: da definição à qualificação dos princípios jurídicos, cit., p. 27) para expressar o pensamento de Karl Larenz.

${ }^{437}$ Lenio Streck (Um sintoma do atraso de nosso direito: acreditar que basta estar na lei. Consultor Jurídico, São Paulo, 17 jul. 2014. Disponível em: <http://www.conjur.com.br/2014-jul-17/senso-incomum-sintomanosso-atraso-nao-basta-estar-lei>. Acesso em: 19 jul. 2014), ao fazer comentários sobre uma decisão proferida pelo Supremo Tribunal Federal, chegou a sugerir, em tom de crítica, que hoje em dia a regra de que não há nulidade sem prejuízo está sendo considerada como um princípio geral do Direito: “Ainda há pouco o Supremo Tribunal Federal deixou de aplicar o artigo 212 do CPP em um caso em que o juiz elaborou toda a prova (...) Argumento do STF: o réu, condenado a 8 anos de reclusão, não teria provado o prejuízo. Fundamento do Pretório Excelso: o princípio geral do direito "não há nulidade sem prejuízo"”.
} 
uma espécie de ponderação de princípios, na qual prevaleça, na grande maioria dos casos, o "princípio" do prejuízo. ${ }^{438}$

Destarte, enquanto se insistir na distorcida posição de que a exigência do prejuízo configura uma espécie de meta-princípio regulador da matéria de nulidades, cada vez mais se verão pronunciamentos judiciais que aceitam a transgressão dos mais comezinhos direitos do acusado em nome de um processo supostamente mais instrumental. E, por seu turno, cada vez menos frequente será a discussão - essa sim, essencial - acerca do ponto central do trabalho, o qual não pode ser outro senão o verdadeiro significado do prejuízo no âmbito específico do processo penal.

E se é preciso dissociar a noção do pas de nullité sans grief da ideia de instrumentalidade das formas, de igual maneira é importante realizar que esta última também não constitui um princípio. Como já denotado acima, impossível negar que as formas dos atos processuais, hodiernamente, não mais podem ser estudadas de maneira hermética; é imprescindível que se examine a finalidade do ato, ou, por outra, sua função no processo. ${ }^{439}$ Mas essa ideia, por si só, não gera um princípio do processo penal. ${ }^{440}$

É certo que o atual Código de Processo Penal pátrio, do mesmo modo que ocorre com as legislações estrangeiras mais modernas, optou por não prever um rol exaustivo de todas as possíveis nulidades. Não se vislumbra ali, também, um modelo de absolutismo total da lei, em que o mais insignificante deslize justificaria uma nulidade. É por isso que se pode afirmar, a partir de inúmeras regras, que o legislador brasileiro lançou mão de uma ideia-guia (Leitedeen) baseada na instrumentalidade (liberdade) das formas.

\footnotetext{
${ }^{438}$ Uma análise mais detida da jurisprudência relativa ao assunto será realizada ainda neste capítulo. Apenas para ilustrar o argumento, de se citar um recente julgado proferido pelo Superior Tribunal de Justiça, no qual, apesar de haver o reconhecimento da violação do princípio da ampla defesa, não se reconheceu a nulidade por ausência de demonstração do prejuízo: "2. Ausência de intimação do defensor constituído pelo acusado sobre a data de julgamento do recurso de apelação, a teor do disposto no artigo $370, \S 1^{\circ}$, do Código de Processo Penal, gera nulidade do processo, tendo em vista que a ausência de publicidade do ato viola o princípio da ampla defesa. Precedentes do STJ. Inteligência do enunciado 431 da Súmula do Supremo Tribunal Federal. 3. No caso dos autos, embora o defensor constituído pelo acusado não tenha sido intimado da data em que o recurso de apelação seria julgado, o certo é que tal omissão não causou qualquer prejuízo à defesa." (STJ, HC 280.477/SP, Ministro Relator Jorge Mussi, $5^{\mathrm{a}}$ T., j. 10.6.2014).

${ }^{439}$ PASSO CABRAL, Antonio do. Nulidades no processo moderno: contraditório, proteção da confiança e validade prima facie dos atos processuais, cit., p. 44-45.

${ }^{440}$ Interessante notar, por exemplo, que Dinamarco (Instituições de direito processual civil, cit., v. 2, p. 615) não classifica a instrumentalidade como princípio, e sim como regra. Também não há no seu estudo qualquer associação entre a instrumentalidade das formas e a máxima do prejuízo.
} 
Resumiriam essa política legislativa as regras - e não princípios! ${ }^{441}$ - que moldam e estruturam o sistema das nulidades no processo penal. Pode-se citar como exemplos dessa ideia-guia (i) a própria regra do prejuízo (art. 563, CPP), (ii) a regra do interesse (art. $565^{442}, \mathrm{CPP}$ ), (iii) as regras de saneamento, ou de convalidação dos vícios processuais (e.g. arts. 572, I, $\mathrm{CPP}^{443}$ ). Do conjunto dessas normas, infere-se que o legislador abriu mão de um sistema rígido de nulidades, prevendo hipóteses em que, mesmo havendo um vício na condução do ato, ainda assim ele será válido. ${ }^{444}$

Por esta razão poder-se-ia dizer que há uma clara ratio instrumental relacionada às normas de nulidade no processo penal brasileiro. Isso não significa, contudo, a existência de um "princípio" da instrumentalidade, que supostamente orientaria o juiz na aplicação da lei. ${ }^{445}$

Não fosse esse o entendimento da matéria, forçoso seria concluir que a solução para anular, ou não, os mais variados vícios passaria, antes de qualquer coisa, por uma espécie de filtro para aquilatar se o ato atingiria sua finalidade. Porém, há uma inversão clara nessa operação. São as regras do Código de Processo Penal - tanto aquelas que estabelecem a tipicidade do ato, quanto aquelas da parte geral das nulidades - que medirão o grau de instrumentalidade do ato, e, portanto, evidenciarão se aquele mesmo ato atingiria o seu objetivo.

Esclarecendo: o processo decisório para verificar se um ato processual defeituoso deve ser anulado não pode partir da ideia de um princípio-maior segundo o qual a forma é livre, desde que o ato atinja seu fim almejado. É, pelo contrário, pela verificação das regras

\footnotetext{
${ }^{441}$ Também não parece ser correto classificar a instrumentalidade das formas naquilo que Humberto Ávila classificou de postulados normativos. Segundo o autor, postulados normativos (também chamados de metanorma) seriam "deveres estruturantes da aplicação de outras normas", os quais "situam-se no próprio nível das normas que estruturam a aplicação de outras." (Teoria dos princípios: da definição à qualificação dos princípios jurídicos, cit., p. 88-89). A instrumentalidade das formas não deve ser considerada um dever que estruture outras normas, pois não há nada na legislação que evidencie isso. Ao contrário, a ideia de instrumentalidade é que exsurge de uma política legislativa, representada pelos dispositivos legais contidos no Código de Processo Penal.

${ }^{442}$ Art. 565, CPP: "Nenhuma das partes poderá arguir nulidade a que haja dado causa, ou para que tenha concorrido, ou referente à formalidade cuja observância só à parte contrária interesse."

${ }^{443} \mathrm{Art}, 572$, I, CPP: "As nulidades previstas no art. 564, III, $d$ e $e$, segunda parte, $g$ e $h$, e IV, considerar-se-ão sanadas se não forem arguidas em tempo oportuno, de acordo com o disposto no artigo anterior." De se esclarecer que o artigo citado representa apenas um, dos inúmeros dispositivos que tratam das hipóteses de saneamento do vício processual.

${ }^{444}$ Há de se indagar: o que impediria o legislador de inserir um artigo no Código de Processo Penal prevendo que qualquer erro de forma resulte em nulidade? Seria esse artigo considerado inconstitucional? Trata-se, portanto, de regras formadoras de um modelo instrumental, mas que não são apegadas a qualquer princípio.

${ }^{445}$ De forma contrária entende Jorge Paschoal (O prejuízo na teoria das nulidades processuais penais e sua análise jurisprudencial nos Tribunais Superiores, cit., p. 308): para quem "a instrumentalidade é um princípio que influencia e orienta tanto o legislador na sua tarefa de fazer leis quanto o juiz na sua função de bem aplicá-las."
} 
(prejuízo, interesse, etc.) que se apura se o ato, mesmo padecendo de vício, atingiu sua finalidade.

A prevalecer que existe um "princípio" da instrumentalidade, seria necessário, seguindo a filosofia da doutrina tradicional (separação das nulidades absolutas e relativas) também aplicar um "princípio da não convalidação das nulidades absolutas". Ou, ainda, por outra, o "princípio do prejuízo presumido", que se aplicaria aos casos de violação a uma garantia constitucional. Dessa forma, haveria uma colisão de princípios no momento de decidir a matéria, e não somente um meta-princípio apto a solucionar todo e qualquer caso.

A verdade é que, em se tratando do tema das nulidades (sobretudo, penais), torna-se temerário estabelecer princípios gerais aptos a servir de fundamento para as decisões. Para se evitar decisões discricionárias fundadas na prevalência de um "princípio da instrumentalidade das formas", faz-se necessário dirimir as questões com base na conjugação de regras estabelecidas pela legislação vigente.

\subsection{A natureza jurídica do "prejuízo" nas nulidades processuais penais}

No item anterior, buscou-se demonstrar que a máxima do pas de nullité sans grief figura como norma-regra em nosso ordenamento penal, e não pode ser confundida com um princípio. Isso porque, pela leitura do artigo 563, do CPP, resta claro que somente serão anulados os atos que gerarem alguma forma de prejuízo a uma das partes. Daí se depreende que não há uma terceira opção, mas apenas duas: ou há prejuízo, e anula-se o ato, ou o prejuízo não existe, e válido permanece o ato. É preciso entender, assim, qual a natureza do prejuízo na teoria das nulidades.

Há quem identifique a inexistência de prejuízo como causa saneadora do vício. $\mathrm{Na}$ realidade, o vetusto Código Rocco italiano, de $1930,{ }^{446}$ fonte inspiradora de nosso atual diploma, bem como o atual Código de Processo Penal daquele país, ${ }^{447}$ considera o fato de

\footnotetext{
${ }^{446}$ Art. 187, última parte: "La nullità di um atto è sanata, se, nonostante l'irregolarità, l'atto ha egualmente conseguito il suo scopo rispetto a tutti gli interessati." Manzini, ao descrever tal causa de sanatória como uma novidade da legislação, assim dizia: "Questa disposizione, nuova in confronto del diritto preesistente, si giustifica considerando che il processo penale non è un'esercitazione accademica e che le formalità processuali non sono fine a se stesse. Ogni atto processuale ha uno scopo, e se codesto scopo è stato conseguito rispetto a tutti gli interessati, è manifesto che, nel caso concretto, l'irregolarità non ha alcuna importanza." (Trattato di diritto processuale penale italiano. 6. ed. Torino: UTET, 1968. v. 3, p. 141).

${ }^{447}$ Art. 187, 3: "La nullità di um atto è sanata se nonostante l'irregolarità l'atto ha egualmente conseguito il suo scopo rispetto a tuttil gli interessati."
} 
o ato atingir a sua finalidade como uma sanatória da nulidade. ${ }^{448}$ Tem-se entendido, outrossim, que uma forma de verificar o atingimento do escopo é a inexistência de prejuízo às partes. Assim, a ausência de prejuízo funcionaria, em última instância, como uma causa saneadora do vício. ${ }^{449}$

Esse entendimento, no entanto, não parece ser o mais correto em relação à sistemática brasileira. Diferentemente do que ocorre com as causas saneadoras dos atos viciados, o instituto do prejuízo não vem para tornar válido o que originalmente era nulo. Se fosse assim, a nulidade existiria independentemente do prejuízo, e poderia eventualmente não ser reconhecida se este estivesse presente. Mas não é esse o caso. É que a própria existência da nulidade pressupõe alguma forma de prejuízo. ${ }^{450}$

PACELLI, por seu turno, entende que o prejuízo configuraria uma espécie de consequência da nulidade. Às suas palavras: "quando se fala em prejuízo para as partes, é preciso ainda distinguir: há nulidades que implicam prejuízos relevantes e outras que não passam da abstração legislativa. Prejuízos relevantes são aqueles que derivam de atos processuais nulos, mas com aptidão para influir na apuração da verdade ou do convencimento judicial." 451

Verifica-se que o autor estabelece um critério de causa-efeito em relação ao prejuízo nas nulidades. Dito de outra maneira, os atos nulos (causa) gerariam um prejuízo (efeito), que, por sua vez, poderia ser classificado em relevante ou irrelevante, tudo a depender do quanto influenciasse no desvendamento da imputação apurada no processo penal.

A se classificar a nulidade como sanção processual $^{452}$ decorrente da imperfeição do ato - posição esta adotada no capítulo antecedente - não há como aceitar a tese segundo

\footnotetext{
${ }^{448}$ É preciso lembrar que O CPP italiano de 1930, em sua redação original, havia abolido por completo a distinção entre nulidade absoluta e relativa, permitindo que todo e qualquer vício fosse sanável. O que determinava a sanabilidade de todo e qualquer defeito processual era o fato de ter o ato atingido, a despeito de sua atipicidade, a finalidade pretendida pela lei.

449،Pertanto come il principio di tassatività esclude che per la sussistenza della nullità sia rilevante il verificarsi di un concreto pregiudizio all'interesse protetto dalla disposizione transgredita, così il concetto di esercizio della facoltà delimita rigidamente il perimentro entro cui l'ordinamento lascia spazio a considerazioni di natura finalistica ou utilitaristica, precludendo all'interprete apllicazione incentrate su fattori diversi e ulteriori da quelli previsti nella disposizione in esame." (DI PAOLO, Gabriella. La sanatoria delle nullità nel processo penale, cit., p. 115-116).

${ }^{450}$ Nesse sentido, elucidativas são as palavras de Jorge Paschoal ( $O$ prejuízo na teoria das nulidades processuais penais e sua análise jurisprudencial nos Tribunais Superiores, cit., p. 319): "Não seria equivocado equiparar - ainda que de modo atécnico - a nulidade ao prejuízo, já que a nulidade, para existir, pressupõe, certamente algum tipo de prejuízo".

${ }^{451}$ PACELLI, Eugenio. Curso de processo penal, cit., p. 823.

452، “...) e, finalmente, para certos desvios de forma estabelece-se a sanção de nulidade, pela qual a lei possibilita que se retire do ato a aptidão de produzir efeitos." (GRINOVER, Ada Pellegrini. O processo: III Série: estudos e pareceres de processo penal, cit., p. 108).
} 
a qual o prejuízo teria natureza jurídica de consequência do ato nulo. De fato, o dano como implicação (derivação) da nulidade pressupõe esta última como vício processual, e não sanção. Seria, de fato, como entender que a nulidade poderia retirar, ou não, a eficácia do ato, tendo como critério para isso o maior ou menor grau do prejuízo causado às partes. A assertiva não procede, pois, em assim sendo, ter-se-ia que admitir a existência de nulidades de pleno direito, cujo reconhecimento independeria de declaração judicial, o que se revela inapropriado em sede de processo penal. ${ }^{453}$

Uma terceira vertente atribui ao prejuízo (ou melhor, à ausência dele) natureza jurídica de causa impeditiva da declaração da nulidade. ${ }^{454} \mathrm{Na}$ lição de HELIO TORNAGHI, para que seja reconhecida uma nulidade, não basta que haja o desrespeito à forma legal; é necessário, ademais, que inexistam causas impeditivas. A ausência de prejuízo, nesse contexto, na qualidade de causa impeditiva, obstaria o reconhecimento da nulidade por parte do magistrado. ${ }^{455}$

Novamente, não parece ser essa a classificação mais adequada. Com efeito, não há como dizer que exista uma nulidade, e que sua declaração dependeria da existência de um prejuízo. Ressalte-se: se não existem, no processo penal, nulidades de pleno direito, o ato nulo (sanção) somente se aperfeiçoa com a decisão desconstitutiva, sendo, dessa forma, impossível se falar, como pretendem alguns, em causa impeditiva de sua declaração se a própria nulidade ainda não se caracterizou.

A rigor, em nosso sistema processual-penal, não se pode falar em nulidade sem prejuízo. Conquanto se estabeleçam diferentes meios para verificação do conteúdo do prejuízo, é certo que sem ele não há ato nulo. Por isso, parece correto afirmar que o prejuízo constitui um pressuposto da nulidade; é preciso analisar, como antecedente necessário, a incidência de um prejuízo às partes causado pelo ato processual defeituoso, pois somente assim poder-se-á falar em invalidade. Frise-se, um erro processual desprovido de prejuízo não gera nulidade.

\footnotetext{
${ }^{453}$ Borges da Rosa (Comentários ao Código de Processo Penal, cit., p. 637) ainda aponta a diferença entre a categoria do prejuízo entre o Direito Substantivo e Direito Adjetivo: "Ocorre nulidade porque, em certos casos, a Lei Substantiva presume a existência de prejuízo oriundo da sua violação, dadas as condições especiais do ato jurídico ou as condições individuais do seu titular. Outro tanto não sucede no Direito Adjetivo, em que o novo sistema de apreciação de nulidades pelo critério da finalidade da lei e do prejuízo aboliu a inflexibilidade da forma e a presunção do prejuízo, só admitidas, em casos excepcionalíssimos."

${ }^{454}$ FEITOZA, Denilson. Direito processual penal: teoria, crítica e práxis, cit., p. 891 . O autor também identifica a (i) falta de interesse e (ii) a falta de lealdade como causas impeditivas de declaração da nulidade.

${ }^{455}$ TORNAGHI, Helio. Curso de processo penal, cit., p. 293.
} 
Ao se atribuir, ao prejuízo, natureza jurídica de pressuposto na teoria das nulidades, torna-se coerente uma vez mais insistir na ideia de que, independentemente da gravidade do defeito, sempre será imprescindível a concretização de um dano para declaração do ato nulo. E por maior que seja a aparente irrelevância de definir ao certo a natureza jurídica do prejuízo, é somente com base nela que se poderá, doravante, iniciar a correta estruturação do pas de nullité sans grief.

\subsection{O papel do pas de nullité sans grief na separação entre nulidade absoluta e relativa: o equívoco de se presumir o que a lei não permite}

A teoria das invalidades processuais, seja no campo civil ou penal, funda-se no binômio absoluta/relativa para classificar as nulidades de acordo com a intensidade do vício. Declara-se uma nulidade absoluta, em tese, quando existente violação de ato responsável por tutelar interesse público, ao passo que a nulidade relativa ocorreria em hipóteses de vícios de atos que cuidariam de interesses privados. ${ }^{456}$

Conforme já se explorou no capítulo anterior, existe na realidade apenas uma diferenciação imaginária entre ambas as formas de nulidade, pois por maior que seja a pretensão de se identificar atos processuais que tutelem interesses particulares, é certo que no processo penal - diferentemente do que ocorre com o processo civil - não há normas de proteção a interesses privados propriamente ditos. Daí decorre a dificuldade em se obter um critério razoavelmente compreensível para a classificação das nulidades, gerando uma jurisprudência confusa e vacilante acerca da matéria. ${ }^{457}$

Esta confusão é ainda agravada pelo critério estabelecido para verificar o prejuízo em um e outro caso. Ao se falar de nulidade absoluta, repete à exaustão a doutrina, o

\footnotetext{
${ }^{456}$ Gustavo Badaró (Processo penal, cit., p. 576-577), retratando a doutrina dominante sobre o tema (que não se confunde com o entendimento do autor), ensina: “A nulidade absoluta é aquela que decorre da violação de uma determinada forma do ato, que visava à proteção de interesse processual de ordem pública. (...) A nulidade relativa é aquela que decorre da violação de uma determinada forma do ato que visa à proteção de um interesse privado."

${ }^{457}$ A divisão entre nulidades absolutas e relativas, e a sua complexa distinção, também é objeto de crítica em outros países. Nas palavras de Binder (El incumplimiento de las formas procesales, cit., p. 101): "Sin embargos es preferible abandonar la dualidad de nulidades absolutas y relativas en el proceso y que no apunta demasiada claridad y funda un falso paralelismo con los conceptos de nulidades absolutas y relativas de los actos jurídicos. De quedar claro que cuando se trata de quebramientos de forma que afectan los principios de protección del imputado esta debe ser oficiosa por parte del juez porque es una de las dimensiones esenciales de la jurisdicción."
} 
prejuízo às partes seria presumido. ${ }^{458}$ Já nas hipóteses de nulidade relativa, o prejuízo haveria de ser comprovado pela parte interessada em ver repetido o ato processual viciado. $^{459}$

De forma ainda mais radical, há entendimento de que nas nulidades absolutas não se exige demonstração do prejuízo. O vício na nulidade absoluta, sustentam aqueles que se associam a tal posição, seria de tamanha ordem que o prejuízo já estaria implícito no próprio ato defeituoso. ${ }^{460}$ Caberia, assim, ao magistrado apenas identificar a violação como resultante de uma nulidade absoluta, sendo desnecessário examinar a ocorrência de dano processual algum às partes. ${ }^{461}$

Acontece que, para que não se faça letra morta da legislação em vigor - bem como de tudo o que foi discutido até aqui -, é preciso rechaçar as teses que propõem a presunção do prejuízo na nulidade absoluta, ou mesmo a desnecessidade da existência deste (prejuízo) em determinados casos. Ao que parece, tais posicionamentos, com vistas a buscar uma estruturação lógica em uma teoria tecnicamente descuidada, recorrem a uma simplificação do tema do prejuízo, deixando de lado aspectos conceituais basilares.

Não se deve olvidar que o prejuízo configura um pressuposto da nulidade. Ao não gerar qualquer prejuízo às partes, ressalte-se, o ato processual não será nulo. De se remeter novamente ao artigo 563 do Código de Processo Penal que, expressando o adágio pas de

\footnotetext{
${ }^{458}$ Nesse sentido, os julgados do Superior Tribunal de Justiça: “O reconhecimento da nulidade não decorreu apenas da omissão do causídico, mas, principalmente, da inércia do Juiz presidente do Tribunal do Júri, que diante da ausência de defesa, não cumpriu o comando do Código de Processo Penal, qual seja, dissolver o Conselho de Sentença e nomear outro defensor para o acusado. Ausência de defesa caracteriza nulidade absoluta, cujo prejuízo é presumido." (STJ, ED no HC 234.758/SP, Ministro Relator Sebastião Reis Junior, $6^{\mathrm{a}}$ T., j. 21.8.2012).

459، A impeditiva de falta de prejuízo aplica-se às nulidades relativas. Se não há prejuízo, não se declara a nulidade relativa. Quanto às nulidades absolutas, há presunção legal de prejuízo, não se lhes aplicando, de modo geral, a impeditiva da falta de prejuízo" (FEITOZA, Denilson. Direito processual penal: teoria, crítica e práxis, cit., p. 891). Da mesma forma entende Nucci (Código de Processo Penal comentado. 8. ed., cit., p. 890): "Logicamente, tal princípio [pas de nullité sans grief] deve ser aplicado com maior eficiência e amplitude no tocante às nulidades relativas, uma vez que o prejuízo, para o caso das nulidades absolutas, é presumido pela lei, inadmitindo prova em contrário."

460“'A doutrina, de modo geral, costuma dizer que, nas nulidades mencionadas no citado art. 564, o prejuízo é 'presumido'. A nosso ver, não se trata de prejuízo presumido porque não há indagar de prejuízo no caso. A nulidade existe, independentemente da verificação do prejuízo, porque não se exige prejuízo para seu reconhecimento. Resulta ela da simples vontade do legislador." (SOUZA, José Barcelos de. Direito processual civil e penal, cit., p. 86). Em posição idêntica: MOSSIN, Heráclito Antonio. Nulidades no direito processual penal, cit., p. 9.

${ }^{461}$ Discorrendo sobre o tema no processo civil, também visto com olhos críticos pelo autor, eis a lição de Antonio do Passo Cabral: "Costuma afirmar a doutrina clássica que o princípio da instrumentalidade das formas não se aplica às nulidades absolutas, ou seja, o exame da finalidade das formas só seria possível quando o interesse protegido pela norma fosse exclusiva ou predominantemente particular, vale dizer, apenas na análise das nulidades relativas, anulabilidades e irregularidades." (Nulidades no processo moderno: contraditório, proteção da confiança e validade prima facie dos atos processuais, cit., p. 46).
} 
nullité sans grief, insere uma norma-regra, que e como tal, promove uma imposição definitiva. ${ }^{462}$ Da leitura de tal dispositivo legal não pode haver outra interpretação senão aquela que exige, sim, de todas as nulidades - relativas ou absolutas - a existência do prejuízo. $^{463}$

Igualmente equivocado parece ser o entendimento segundo o qual o prejuízo se presume nos casos de nulidade absoluta. A bem da verdade é que, normalmente, quem sustenta essa presunção apenas o faz para dizer que o prejuízo é exigido, mas deixa de realizar qualquer exame em relação ao teor da presunção em si. Ou seja, justamente porque seria exigido um prejuízo para todas as nulidades, afirma-se amiúde que na nulidade absoluta este também há de estar presente, mas que seria desnecessário demonstrá-lo, pois já estaria presumido.

Porém, de onde nasce tal presunção $?^{464}$ Seria ela iuris et de iure, ou comportaria prova em contrário? Qual o grau de prova que se exigiria para reverter tal presunção? Há quem afirme que se extrai referida presunção da lei, notadamente o artigo 564, do Código de Processo Penal, que prevê um rol de nulidades, algumas das quais não podem ser sanadas (art. 572). Decorreria daí, portanto, a ideia de uma presunção legal - advinda do próprio código - do prejuízo. ${ }^{465}$

Como é sabido, contudo, mesmo diante do confuso quadro atual, as nulidades absolutas já não estão mais restritas a um rol taxativo. Com efeito, a despeito de existirem nulidades absolutas insculpidas no rol do artigo 564, há outros tantos casos de atos defeituosos que não se encontram ali previstos, mas que igualmente culminam em nulidade absoluta. Assim, a estabelecer como correta a tese do prejuízo presumido nas nulidades absolutas, dada a realidade atual, ter-se-ia que admitir uma presunção legal para as

\footnotetext{
${ }^{462}$ A expressão é de Virgílio Afonso da Silva (Direitos fundamentais: conteúdo essencial, restrições e eficácia, cit., p. 45).

${ }^{463} \mathrm{Na}$ mesma direção é a lição de Ada Pellegrini Grinover, Antonio Magalhães Gomes Filho e Antonio Scarance Fernandes (As nulidades no processo penal, cit., p. 28-29): "No entanto, deve-se salientar que, seja o prejuízo evidente ou não, ele deve existir para que a nulidade seja decretada. E nos casos em que ficar evidenciada a inexistência de prejuízo não se cogita de nulidade, mesmo em se tratando de nulidade absoluta."

464، Alguns preferem afirmar que nesses casos haveria uma presunção de prejuízo estabelecida pelo legislador, mas isso não parece correto em todos os casos, pois as presunções levam normalmente à inversão do ônus da prova, o que pode não ocorrer quando a existência de dano estiver fora de dúvida." (GRINOVER, Ada Pellegrini; FERNANDES, Antonio Scarance; GOMES FILHO, Antonio Magalhães. As nulidades no processo penal, cit., p. 28).

${ }^{465}$ No tema, há de se lembrar da lição de Leone, para quem "la taxatividad está para significar que el nexo ha sido reconocido por el legislador, quien, al conminar la nulidad, lo ha puesto como base de ella; el perjuicio está cristalizado en la norma que conmina la nulidad; y se lo presume, por tanto, iure et de iure." (Tratado de derecho procesal penal, cit., v. 1, p. 264).
} 
nulidades já previstas em lei, e para as outras nulidades, não previstas expressamente em lei, haveria uma perigosa lacuna interpretativa.

De se ver, portanto, que não se pode conceber uma teoria que fundamente o prejuízo em presunções genéricas, desprovidas de lei que a regulamentem, sobretudo em assunto tão delicado como o é o das nulidades. Deixar à mera casuística para decidir em que casos de nulidade absoluta há de se permitir uma prova em contrário do prejuízo daria margem a uma insegurança jurídica intolerável - igual, aliás, à que vivemos hodiernamente - no âmbito do processo penal.

Nesse sentido, o Supremo Tribunal Federal recentemente tem acertado ao ressaltar a obrigatoriedade, inclusive nas nulidades absolutas, de demonstração do prejuízo. O leading case referente ao assunto pode ser atribuído ao Habeas Corpus $\mathrm{n}^{\circ} 81.510,{ }^{466}$ do qual extrai-se a seguinte assertiva: "tem-se, até aqui, hipótese típica de invocação do princípio fundamental da disciplina das nulidades processuais - corolário da natureza instrumental do processo - o velho pas de nullité sans grief, cujo domínio não se adstringe ao das nulidades relativas." ${ }^{467}$

É fundamental esclarecer que, ao se exigir a demonstração do prejuízo em todas as nulidades, não se está, de forma alguma, impondo um maior gravame ao acusado durante a persecução penal, nem mesmo defendendo um processo penal despreocupado com a instrumentalidade constitucional. Muito pelo contrário, o que se pretende no presente trabalho é justamente encontrar parâmetros mais precisos e rígidos para respeitar o devido processo legal.

Da forma como se encontra o estudo das nulidades - ora se verificando um prejuízo nas nulidades absolutas por presunção, ora se declarando que aquele mesmo defeito sequer configura nulidade absoluta - o que se verifica é um verdadeiro caos temático, que deixa ao alvedrio completo do julgador a decisão sobre a gravidade do vício. É por isso que se torna necessário explorar e trabalhar muito mais com o conteúdo do prejuízo - como será feito adiante - do que com o fato de ele ser presumido ou não nas diferentes espécies de nulidade.

\footnotetext{
${ }^{466}$ STF, HC 81.510/PR, Ministro Relator Sepúlveda Pertence, $1^{\mathrm{a}}$ T., j. 11.12.2001.

${ }^{467}$ No mesmo sentido, ainda no STF, há de se citar: HC 85.155/SP, Rel. Min. Ellen Gracie, j. 22.3.2005; HC 84.197, Rel. Min. Joaquim Barbosa, j. 19.4.2005; HC 116.713/MG, Rel. Min. Ricardo Lewandowski, j. 11.6.2013.
} 


\subsection{A problemática jurisprudência pátria acerca do pas de nullité sans grief}

Até aqui, buscou-se demonstrar que a teoria das nulidades no processo penal, da forma como está sendo estudada atualmente, para além de estar desgarrada das bases principiológicas corretas, ${ }^{468}$ tem criado uma crescente iniquidade na aplicação dos casos concretos. Chega o momento, portanto, de lançar luzes em direção ao estudo jurisprudencial da matéria, justamente com intuito de comprovar o perigo na manutenção do status quo, e a importância de se encontrar novas direções para a resolução de questões relativas à nulidade processual.

Cumpre esclarecer que o recorte feito para o estudo dos julgados não se limita a um ou outro tribunal. Na realidade, embora haja maior enfoque nas cortes superiores, a ideia empregada na presente análise jurisprudencial se baseia mais na demonstração dos contornos - abertos e confusos - exegéticos da regra do artigo 563 do Código de Processo Penal do que propriamente em um levantamento específico e quantitativo a respeito do assunto. ${ }^{469}$ Os arestos - e a análise deles - adiante servirão apenas para exemplificar, de forma empírica, as diversas interpretações conferidas à regra do pas de nullité sans grief.

Ver-se-á adiante que inexiste um padrão racional e coerente para o reconhecimento do prejuízo, mas sim um critério centrado em bordões retrógrados e equivocados, que mais se aproximam de um modelo decisionista processual, ${ }^{470}$ desprovido de qualquer compromisso com uma fundamentação fática e determinada para o caso concreto. ${ }^{471}$

O ponto central desse capítulo não será encontrar uma solução correta para cada situação específica, mas sim apenas pontuar as possíveis contradições existentes na jurisprudência. A proposta de uma aplicação mais objetiva da regra do prejuízo no âmbito

\footnotetext{
${ }^{468}$ Sobre esse ponto específico, adverte Binder (El incumplimiento de las formas procesales, cit., p. 15): "Cuanto más prolífera la jurisprudencia sobre la nulidad en el proceso penal más se pierde de vista sus principios fundamentales."

${ }^{469}$ Para um trabalho mais detalhado sobre jurisprudência relativa à regra do prejuízo, cf. PASCHOAL, Jorge Coutinho. O prejuízo na teoria das nulidades processuais penais e sua análise jurisprudencial nos Tribunais Superiores, cit.

470،El decisionismo es el efecto de la falta de anclajes empíricos precisos y de la consiguiente subjetividad de los presupuestos de la sanción en las aproximaciones sustanciales en las técnicas conexas de prevención y de defensa social (...) pero, por otro lado, se manifiesta también en el carácter subjetivo del juicio, que, en ausencia de referencias fácticas exactamente determinadas, resulta basado en valoraciones, diagnósticos o sospechas subjetivas antes que en pruebas de hecho.” (FERRAJOLI, Luigi. Derecho y razón, cit., p. 43).

${ }^{471}$ Esse problema não fica adstrito somente ao processo penal brasileiro. Alan Dershowitz, ao fazer comentários sobre o instituto do "harmless error", lança as seguintes críticas: "What, afterall, is the harmless error rule? It is basically a judicial assurance that nearly anything will be tolerated in regard to an obviously guilty defendant. If the defendant is so obviously guilty, then basically any misconduct by a prosecutor will not have made the difference between conviction and acquittal." (Letters to a young lawyer. New York: Basic Books, 2001. p. 144).
} 
das nulidades processuais-penais será levada a efeito no próximo capítulo, em que se tentará trazer critérios mais claros e precisos no tocante à matéria.

\subsubsection{Nulidade em razão da ausência do acusado em audiência}

Como primeiro ponto jurisprudencial a ser debatido, de se lançar luzes sobre uma discussão travada já há muito por nossas cortes. A ausência de intimação para que o réu preso esteja presente em audiência de testemunha de acusação gera, por si só, um prejuízo passível de nulidade? Independentemente de ser tachada de nulidade absoluta ou relativa, é necessário analisar o que se entende por prejuízo nesses casos.

Por oportuno, esclareça-se que a Lei 11.719/08, responsável por conferir nova redação ao artigo 400 do CPP, prevê uma só audiência, no bojo da qual haverá a instrução e o julgamento, em tese eliminando a separação até então existente entre audiência de oitiva das testemunhas de acusação e de defesa. No entanto - e quem milita com frequência na área penal não desconhece tal fato - não são raras as oportunidades em que, por ausência de uma testemunha ou por necessidade de dilação probatória, a audiência (como regra, una) é realizada em duas ou mais etapas. As decisões colacionadas abaixo se referem, portanto, à legalidade de se realizar uma dessas audiências sem a presença do acusado preso.

O Supremo Tribunal Federal, ao se debruçar sobre o tema específico, já se pronunciou inúmeras vezes sobre a prescindibilidadede condução do acusado preso à audiência de testemunha de acusação. O prejuízo, reiteram com frequência as decisões, não se evidencia pela simples ausência do acusado, mas deve ser forçosamente demonstrado pela defesa.

Nesse sentido, de se registrar excerto do acórdão do Recurso Ordinário em Habeas Corpus 109.978, o qual, de maneira ilustrativa, representa o entendimento da Corte Suprema: "Dessume-se, portanto, que o fato de o paciente não estar presente à audiência em que ouvida a testemunha não implica, por si só, a nulidade do processo, dado que seu não comparecimento somente geraria nulidade se demonstrado, de modo efetivo e concreto o prejuízo (pas de nullité sans grief) (...) Acrescente-se, ainda, que a possibilidade de o réu não comparecer à audiência é uma expressão do direito constitucional ao silencio (art. $5^{\circ}$, LXIII, da CF/88), pois nemo tenetur se detegere. In casu, o paciente encontrava-se sob custódia e o Juízo deprecante deixou de requisitá-lo para participar de audiência de oitiva 
de testemunhas no juízo deprecado, em razão de dificuldades enfrentadas pelo Estado de São Paulo em 'promover o transporte e a devida escolta dos presos, assegurando, todavia, a presença de seu defensor no ato.",472

Extrai-se do trecho da decisão supratranscrita que o comparecimento do acusado nas audiências de testemunhas não é obrigatório. A sua ausência, ainda que impugnada tempestivamente, constitui nulidade relativa, sendo certo que a comprovação concreta e efetiva do prejuízo é imperiosa para realização de novo ato. Em última instância, ainda segundo o aresto, a Constituição assegura ao réu o direito de permanecer em silêncio, e a sua ausência em eventual audiência de testemunhas poderia significar uma concretização de tal direito, inexistindo, portanto, qualquer prejuízo.

Para diagnosticar a problemática lógica que embasa o decisum mencionado confusão essa que se repete em tantas outras decisões - torna-se recomendável destrinchar as questões suscitadas, de maneira a examinar, de um lado, o que de fato é fruto de uma teoria das nulidades, e, de outro, aquilo que já se tornou uma repetição do lugar-comum, desprovido de um fundamento legítimo.

Pois bem. A discussão gira em torno da ausência, sem consentimento do acusado preso, às audiências no decorrer da instrução criminal, sobretudo naquela designada para oitiva das testemunhas de acusação. Inicialmente, e por mais óbvio que possa parecer, é preciso ter em mente que o acusado não escolhe ser processado; também não opta por ser preso; outrossim, o acusado não possui qualquer poder de interferência na pauta das audiências, e tampouco poderá ser conduzido aos atos judiciais sem a participação do Estado.

Levando tais informações em consideração, o Estado (aqui representado por seu poder jurisdicional) resolve, por supostas dificuldades em promover a escolta, não conduzir o acusado a uma audiência em que serão ouvidas as testemunhas de acusação. De acordo com o entendimento jurisprudencial assentado, referido vício configuraria uma nulidade relativa, exigindo da defesa a comprovação do prejuízo gerado pela ausência do imputado. ${ }^{473}$

\footnotetext{
${ }^{472}$ STF, RHC 109.978/DF, Rel. Ministro Luiz Fux, $1^{\text {a }}$ T., j. 18.6.2013. Em idêntico sentido, ainda no STF: HC 115.266/ES, Rel. Ministro Gilmar Mendes, $2^{\mathrm{a}}$ T., j. 10.9.2013; HC 113.837/RS, Rel. Ministra Rosa Weber, $1^{a}$ T., J. 19.3.2013. No STJ: HC 41.656/SP, Rel. Ministra Laurita Vaz, $5^{\mathrm{a}}$ T., j. 24.4.2014; HC 176.894, Rel. Ministra Maria Thereza de Assis Moura, 6a T., j. 15.8.2013.

${ }^{473}$ A questão também sempre mereceu reflexão no Direito italiano. A ausência do imputado preso no giudizio ordinario é considerada, pela Suprema Corte (Cassazione), como nulidade de ordem geral, e não absoluta. A lição é de Fanuli (Le nullità nel processo penale, cit., p. 74-75): "La Cassazione há ripetutamente affermato che la mancata traduzione in udienza dell'imputato detenuto e regolarmente citato determina uma nullità di ordine generale $e x$ art. 178, lett. c), c.p.p. Trattasi però di nullità che, esulando dalle ipotesi di cui all'art. 179 c.p.p., no è assoluta, ma a carattere cosiddetto intermedio e, como tale, è soggetta alle regole di deducibilità di cui all'art. 182 c.p.p."
} 
É de se indagar: qual o fato, com base na teoria atual, que possibilita o julgador chegar à conclusão de que o vício configura uma nulidade relativa? Ora, se estamos a utilizar da tradicional classificação decorrente dos interesses atingidos pelo vício (interesse privado $=$ nulidade relativa; interesse público $=$ nulidade absoluta), parece ser razoável assumir que a ausência do acusado configura um vício que vergasta diretamente o interesse público, já que, afinal, é o direito à prova (como desdobramento da autodefesa) que está sendo diretamente atingido. ${ }^{474}$

A respeito da importância da presença do acusado em audiência, e sua relação direta com o princípio constitucional da ampla defesa, eis a lição de BADARÓ: "O direito de presença é exercido com comparecimento em audiências pelo acusado. A sua presença permitirá uma integração entre a autodefesa e a defesa técnica na produção da prova. Muitos fatos e pormenores mencionados por testemunhas são do conhecimento pessoal do acusado, que, por estar diretamente ligado aos fatos, poderá auxiliar o defensor na formulação de perguntas e na demonstração de incongruências ou incompatibilidades do depoimento. ${ }^{475}$ Assim, a restrição da participação do acusado na audiência de oitiva de testemunhas pode implicar séria violação do direito de defesa como um todo."476

Desse modo, a despeito de atingir inequivocamente um interesse público (constitucional), o defeito é considerado uma nulidade relativa. Na realidade, não há uma preocupação por fundamentar a razão pela qual se classifica mencionado vício em nulidade relativa. Isso já constitui, por assim dizer, um pressuposto das decisões (como se existente norma a assim definir), as quais apenas reproduzem, sem maiores reflexões, que "o Supremo Tribunal Federal fixou entendimento no sentido de que a realização da audiência

\footnotetext{
${ }^{474}$ Conforme explica Antonio Scarance Fernandes (Processo penal constitucional, cit., p. 81 ), o direito à prova desdobra-se em vários direitos da parte, dentre os quais consta também o direito a participar da produção da prova.

${ }^{475}$ Sobre a importância da presença das partes como condição de validade da prova, cf. GRINOVER, Ada Pellegrini. O conteúdo da garantia do contraditório. In: GRINOVER. Ada Pellegrini. Novas tendências do direito processual. Rio de Janeiro: Forense Universitária, 1996. Na doutrina italiana: "Nel suo significato forte, il principio del contraddittorio comporta la partecipazione delle parti alla formazione della prova." (TONINI, Paolo. Lineamenti di diritto processuale penale, cit., p. 324).

${ }^{476}$ BADARÓ, Gustavo Henrique Righi Ivahy. Processo penal, cit., p. 21-22. Vale aqui também o magistério de Rogério Schietti Machado (MACHADO, Rogério Schietti. Garantias processuais nos recursos criminais. 2. ed. São Paulo: Atlas, 2013. p. 132-133) para quem "a possibilidade de que o próprio acusado intervenha, direta e pessoalmente, na realização dos atos processuais, constitui, assim, a autodefesa (...) Saliente-se que a autodefesa não se resume à participação do acusado no interrogatório judicial, mas há de estender-se a todos os atos de que o imputado participe. Na verdade, desdobra-se a autodefesa em 'direito de audiência' e em 'direito de presença', é dizer, tem o acusado o direito de ser ouvido e falar durante os atos processuais, bem assim o direito de assistir à realização dos atos processuais, sendo dever do Estado facilitar seu exercício, máxime quando o imputado se encontre preso, impossibilitando de livremente deslocar-se ao fórum."
} 
para oitiva de testemunhas sem a presença do acusado é causa de nulidade relativa, cujo reconhecimento depende da demonstração de prejuízo efetivo e concreto para defesa". ${ }^{47}$

Se essa mácula específica configura uma nulidade relativa - e foi assim, como se mostrou, que já definiu a jurisprudência -, então se torna necessário, à luz da teorização geralmente adotada, que a parte demonstre o prejuízo causado pelo ato. E esse prejuízo, vale ressaltar, há de ser efetivo e concreto. Não comprovado o prejuízo pela defesa, de nulidade não se poderia falar, gerando o ato todos os seus efeitos, como se válido fosse.

Mas de que prejuízo se está a falar? Considerando que o acusado não esteve presente à audiência, como apontar um dano efetivo à sua defesa, se não fora concedida a ele a possibilidade de comparecimento ao ato? Caberia ao acusado enumerar as perguntas que seriam feitas se estivesse no local? E, neste mesmo contexto, caberia ao magistrado avaliar se tais indagações, que não foram levantadas na primeira oportunidade, poderiam resultar em um depoimento diverso da testemunha e, por isso, prejudicar o réu?

Ao se considerar que a mera ausência do acusado não constitui, por si, um prejuízo, de fato o que é exigido da defesa, nesses casos, é uma verdadeira prova hipotética (do que poderia ter acontecido!), senão impossível, de que o vício gera um prejuízo ao acusado.

Note-se o equívoco no processo decisório: o acusado, preso, não comparece ao ato processual designado pelo juízo, única e exclusivamente porque o Estado não dispõe de meios para conduzi-lo até o local; a audiência é realizada, mesmo sem a sua presença; ao se suscitar o vício, o magistrado afirma ser uma hipótese de nulidade relativa (sem dar maiores explicações), exigindo da defesa, que não teve responsabilidade pelo defeito processual, a demonstração do prejuízo gerado. Trata-se, em verdade, de uma dinâmica que, embora possa prestigiar a celeridade do processo, desrespeita princípios basilares de nossa Constituição.

É certo que há precedentes do próprio Supremo Tribunal Federal afirmando que assiste ao réu preso o direito de comparecimento à audiência de instrução em que serão inquiridas testemunhas arroladas pelo Ministério Público, sob pena de nulidade absoluta. Assim, diferentemente do que restou decidido nos julgados destacados acima, o prejuízo

\footnotetext{
${ }^{477}$ STF, RHC 109.978, Rel. Ministro Luiz Fux, $1^{\text {a }}$ T., j. 18.6.2013. O trecho transcrito acima, apesar de ser retirado desse caso específico, repete-se, com a inclusão ou supressão de algumas poucas palavras, em outros tantos julgados, de forma que não se esclarece jamais de onde se retira a ideia de que a ausência do réu na audiência configure uma nulidade relativa. Apenas para exemplificar, cite-se, no STF: HC 68.436, Rel. Ministro Celso de Mello, $1^{a}$ T., j. 6.8.1991; RHC 120.661/DF, Rel. Ministro Dias Toffoli, $1^{a}$ T., j. 6.5.2014.
} 
estaria presumido, não cabendo à defesa o ônus de comprová-lo. Em relação a essa posição, esclarecedor o julgamento do Habeas Corpus $\mathrm{n}^{\mathrm{o}} 111.728,{ }^{478}$ em que se questionou inclusive a necessidade de edição de súmula vinculante, tamanha a confusão sobre o tema. ${ }^{479}$

Seja como for, resta claro que, conquanto a jurisprudência aplique a teoria tradicional das nulidades, a verdade é que inexiste uma genuína discussão acerca do prejuízo. Com efeito, ou a Corte, de um lado, entende que a ausência de requisição do acusado para audiência configura nulidade relativa, tornando a comprovação do prejuízo quase impossível, ou, de outro, se pronuncia no sentido de ser uma nulidade absoluta, situação em que sequer se coloca em análise a existência do prejuízo. Enfim, tudo irá depender de um subjetivismo do magistrado, sem qualquer aprofundamento técnico, no tocante à classificação (absoluta/relativa) dada ao defeito processual.

\subsubsection{Nulidade da decisão de recebimento da denúncia por carência de motivação}

Outro vício que parece, ainda que à luz da teoria tradicional da nulidade, não receber o correto tratamento pela jurisprudência é a carência de motivação da decisão que recebe a denúncia. Esclareça-se, por pertinente após as mudanças do Código de Processo Penal, que a decisão a que se fará referência nesse item é aquela por meio da qual o magistrado lança um juízo de admissibilidade da inicial acusatória, rejeitando as teses levantadas na resposta à acusação (recebimento definitivo da imputação). ${ }^{480}$

\footnotetext{
${ }^{478} \mathrm{STF}, \mathrm{HC} \mathrm{n}^{\mathrm{o}}$ 111.728, Rel. Ministra Cármen Lúcia, 2a T., j. 19.2.2013.

479،A Senhora Ministra Carmen Lúcia - Apenas acho que devemos pensar num quadro até um pouco mais amplo do que só o Supremo - por exemplo, a edição de uma súmula -, porque, neste caso aqui, o próprio Tribunal de Justiça aceitou na apelação, deu provimento para declarar a nulidade, o juiz requisitou e fez constar que, expressamente, embora requisitado, não forma apresentados em audiência. Ou seja, a questão fica por conta do Poder Executivo. Talvez devêssemos pensar, sim, e formular alternativas para que houvesse algo que pudesse ser feito - não sei se no planto até do CNJ, talvez, que tem tido atuação, desde a Presidência, mesmo de Vossa Excelência - no sentido de conduzir a que houvesse não a punição, mas mais que uma recomendação (...) O Senhor Ministro Teori Zavascki - Tenho a impressão que uma súmula vinculante impediria, num caso como esse, que o juiz realizasse a audiência. Acabaria o problema. Porque, na verdade, o que aconteceu aqui é que o juiz, mesmo não tendo o réu sido apresentado, fez a audiência.”

${ }^{480}$ As alterações legislativas trazidas pela Lei 11.719/08, e a consequente modificação do CPP, criaram uma divergência, na doutrina, relativa ao momento de recebimento da denúncia. Para alguns autores (cf. NUCCI, Guilherme de Souza. Código de Processo Penal comentado. 8. ed., cit., p. 720), o recebimento da denúncia dar-se-ia na fase do artigo 396, caput, CPP, oportunidade em que seriam analisadas as hipóteses de inépcia da denúncia. Há outra corrente que sustenta (cf. BADARÓ, Gustavo Henrique Righi Ivahy. Processo penal, cit., p. 426), com base em uma interpretação corretiva, parcialmente ab-rogante, que a denúncia seria recebida apenas na fase do art. 399, do CPP, em conjunto com a análise de uma possível absolvição sumária. Adota-se, aqui, como correta uma terceira vertente (cf. GRINOVER, Ada Pellegrini; FERNANDES, Antonio Scarance; GOMES FILHO, Antonio Magalhães. Nulidades no processo penal, 12. ed., cit., p. 235) que defende existir dois juízos a respeito da viabilidade da acusação: um liminar (art. 396, CPP) e outro definitivo (art. 399, CPP). Para efeitos do exame jurisprudencial levado a efeito nesse capítulo, será considerado apenas o recebimento da denúncia definitivo.
} 
Como é cediço, o artigo 396-A do Código de Processo Penal, dispõe sobre a resposta à acusação, peça na qual o acusado poderá suscitar as mais diversas questões para rebater as imputações que recaem contra si. ${ }^{481}$ Ao receber a denúncia, o magistrado terá a oportunidade de aquilatar, ainda que perfunctoriamente, se a versão acusatória se sustenta frente aos argumentos deduzidos por meio da defesa inicial.

Ocorre que não são raros os casos nos quais, após a apresentação da resposta à acusação, em que foram levantadas inúmeras questões em defesa do acusado, o magistrado se limita a consignar que não estão presentes as hipóteses de absolvição sumária, previstas no artigo 397, do Código de Processo Penal. ${ }^{482}$ Trata-se de decisão padrão, genérica, que deixa de analisar - ou ao menos não o faz por escrito - os pontos suscitados pela defesa.

Incitados a se manifestarem acerca de uma possível nulidade em virtude de carência de motivação, os Tribunais pátrios, de maneira quase unânime, têm se pronunciado no sentido de que a decisão de recebimento da denúncia não exige uma fundamentação exaustiva, mas apenas uma declaração de admissibilidade da acusação, sob pena de se aprofundar antecipadamente sobre o mérito dos fatos. ${ }^{483}$

Importante mencionar que a decisão de admissibilidade da denúncia funciona - ou melhor, deveria ser assim considerada - como genuíno filtro para se evitar que acusações infundadas, desprovidas de lastro probatório ou jurídico, possam deflagrar processo criminal degradante. É dizer: o exame detido do magistrado será imprescindível para impedir que um indivíduo seja submetido a uma persecução penal - e todas as mazelas a ela inerentes - desnecessariamente. ${ }^{484}$

\footnotetext{
${ }^{481}$ Sobre a relevância e o conteúdo da resposta à acusação, prevista no artigo 396-A, do CPP, leciona Leandro Galluzzi dos Santos (In: MOURA, Thereza Rocha de Assis (Coord.). As reformas no processo penal. São Paulo: Ed. Revista dos Tribunais, 2008. p. 325): "Pela nova sistemática, a defesa escrita será muito parecida com a contestação do processo civil. Não há, contudo, aplicação do princípio da eventualidade, mas é nesta fase do processo que o acusado deverá apresentar de maneira mais ampla possível a sua defesa escrita. Neste momento deverá o acusado juntar os documentos que comprovem sua inocência e especificar as provas que pretende produzir, como as periciais, por exemplo."

${ }^{482} \mathrm{O}$ emprego da fonte itálica não é por acaso. Apesar de não se fazer no texto remissão direta a nenhuma decisão específica, está-se transcrevendo, em verdade, uma assertiva que já se tornou lugar-comum nas decisões prolatadas por nossas cortes.

${ }^{483}$ Nesse sentido, no STJ: RHC 38.153/MG, Rel. Ministra Laurita Vaz, 5a T., j. 22.4.2014; HC 223.266/SP, rel. Min. Jorge Mussi, $5^{\text {a }}$ T., j. 5.3.2013; RHC 39.890/PR, Rel. Ministro Sebastião Reis Junior, 6 ${ }^{a}$ T., j. 21.11.2013. Nesse mesmo sentido, no STF: RHC 105.431, rel. Ministra Cármen Lúcia, $1^{a}$ T., j. em 2.8.2011.

${ }^{484}$ Cumpre transcrever as palavras de Aury Lopes Junior, o qual, em nota de rodapé, lembra o seguinte: "ilustrativa é a expressão pena de banquillo, consagrada no sistema espanhol, para designar a pena processual que encerra o 'sentar-se no banco dos réus'. É uma pena autônoma, que cobra um alto preço por si mesma, independentemente de futura pena privativa de liberdade (que não compensa nem justifica, senão que acresce o caráter punitivo de todo o ritual judiciário)." (Direito processual penal. 10. ed. São Paulo: Saraiva, 2013. p. 298).
} 
A par disso, o dever de motivação da decisão judicial, de índole constitucional (art. 93, IX, CF), exige que o magistrado externe as razões pelas quais, ainda que em fase de cognição sumária, afasta os argumentos levantados pela defesa. Ou, por outra: é imprescindível que se possa ao menos identificar que o julgador de fato levou em consideração as teses suscitadas por ambas as partes para lançar sua decisão. ${ }^{485}$

É verdade que há quem entenda ter a decisão que recebe a denúncia natureza de mero despacho, tornando-se assim desnecessário que o magistrado forneça uma motivação nessa fase processual. Porém, não é possível concordar com tal ponto de vista, pois tal decisão, para muito além de um simples ato de movimentação processual, ${ }^{486}$ constitui uma (e única) oportunidade para antecipação do julgamento de uma acusação já de início fadada à improcedência. ${ }^{487}$

Sobre a motivação externada no momento do juízo de recebimento da denúncia, Antonio Magalhães Gomes Filho assevera que "a esse modelo de decisão deve corresponder uma adequada justificação, em que o juiz demonstre haver examinado tais questões dizendo por que concluiu pela admissibilidade da acusação. Trata-se também aqui de conferir à exigência constitucional de motivação de todas as decisões judiciais a apontada função de garantia da efetiva cognição judicial." ${ }^{488}$

Ora, se é assim, e novamente recorrendo à teoria tradicional das nulidades, por qual razão deveria a carência de motivação no momento de admissibilidade da denúncia constituir uma nulidade relativa, conforme tem entendido, de forma iterativa, a jurisprudência? A necessidade de fundamentação das decisões judiciais certamente não pode ser considerada um dever que vise à proteção de um interesse privado. Antes, é uma garantia processual e política que legitima a atividade jurisdicional. ${ }^{489}$

\footnotetext{
${ }^{485}$ Para Michele Taruffo a motivação "nasce dal considerar la giurisdizione come campo nel quale emergono e trovano attuazione non solo una funcione essenciale dello Stato di diritto, ma soprattutto i dirritti fondamentali dei cittadini." (Il significato constituzionale dell'obbligo di motivazione. In: GRINOVER, Ada Pellegrini; DINAMARCO, Candido Rangel; WATANABE, Kazuo. Participação e processo. São Paulo: Ed. Revista dos Tribunais, 1988. p.40-41).

${ }^{486}$ BADARÓ, Gustavo Henrique Righi Ivahy. Processo penal, cit., p. 427.

${ }^{487}$ Salutares, nesse sentido, são as palavras do Ministro Félix Fischer: "Se não fosse necessário exigir que o Magistrado apreciasse as questões relevantes trazidas pela defesa - sejam preliminares ou questões de mérito - seria inócua a previsão normativa que assegura o oferecimento de resposta ao acusado." (STJ, HC 138.089/SC, Rel. Ministro Félix Fischer, j. 2.3.2010)

${ }^{488}$ GOMES FILHO, Antonio Magalhães. A motivação das decisões penais. 2. ed. São Paulo: Ed. Revista dos Tribunais, 2013. p. 172.

${ }^{489}$ Vale reproduzir aqui as palavras de Adauto Suannes (Os fundamentos éticos do devido processo penal, cit., p. 282), "a necessidade de motivação das decisões que impliquem o cerceamento da liberdade humana, seja de forma provisória, seja definitivamente, decorre, pois, da chamada humanização do processo, que longe de significar exagerado endeusamento do réu, é apenas e tão-somente o reconhecimento de que os
} 
À luz desses argumentos, não parece o mais acertado defender que a nulidade seja relativa, notadamente porque a deformidade do ato atinge diretamente uma regra constitucional. Assim, ou bem se entende, por um lado, que a doutrina atual predominante sobre nulidades não mais se revela adequada, ou então, de forma diversa, é preciso reconhecer que o vício configura uma nulidade absoluta, presumindo-se a ocorrência do prejuízo às partes.

Todavia, novamente aqui a jurisprudência é omissa em fornecer razões pelas quais o vício resulta em nulidade relativa; tornou-se já uma espécie de verdade incontestável. Exige-se, por consequência, a pretexto de requisito para anulação do ato processual, que a parte comprove o prejuízo pela ausência de motivação.

Interessante notar, ademais, que inúmeros julgados, nesses casos específicos, concluem inexistir prejuízo por ausência na motivação quando há a prolação de decisão condenatória superveniente. Infere-se, a partir de tais precedentes, que o prejuízo de não se fundamentar corretamente a decisão de recebimento da denúncia será "sanado" se, ao final do processo, o acusado for considerado culpado. ${ }^{490}$

Note-se o raciocínio empregado: contra um agente recai uma acusação formal; o procurador desse indivíduo apresenta a sua primeira versão defensiva (resposta à acusação), com vistas a rechaçar as imputações feitas; o juiz, por sua vez, sem declinar qualquer motivação, apenas recebe a denúncia; a defesa, então, argui a nulidade do ato, por carência da necessária fundamentação, alegando que o prejuízo se caracteriza pela deflagração de um processo penal, sem que o magistrado tenha demonstrado ter analisado as teses defensivas; o tribunal, por derradeiro, alega que o vício configura uma nulidade

valores humanos fundamentais devem ser preservados, independentemente da gravidade do fato que se imputa a alguém. Poder-se-ia até dizer que a punição do pecado não pode levar ao aviltamento do pecador, mesmo porque, sob o ponto de vista ético, somente um Estado que respeita a dignidade da pessoa pode exigir dos seus cidadãos que tenham esse respeito. Se o Estado, por intermédio do juiz, age arbitrariamente, como esperar que o cidadão comum aja não-arbitrariamente?"

${ }^{490} \mathrm{~A}$ demonstrar de forma concreta mencionado entendimento, transcreva-se trechos de alguns acórdãos: "E, no caso em apreço, quedou-se o impetrante em demonstrar eventual prejuízo suportado pela paciente ante a ausência de análise das questões suscitadas na defesa preliminar, razão pela qual não há que se falar em invalidação da decisão de recebimento da denúncia por falta de formalidade. Dessa forma, cai por terra a pretensão almejada, tendo em vista que a magistrada singular, ao proferir sentença condenatória, realizou juízo que abrange o âmbito de admissão da peça vestibular, entendendo, ainda, ao sopesar todo o conjunto fático-probatório produzido na instrução criminal, pela existência de provas da materialidade do crime e autoria assesta à paciente." (STJ, HC 194.601/BA, Rel. Ministro Jorge Mussi, 5a T., j. 13.8.2013). "Não há falar em nulidade no recebimento da denúncia, porquanto não há efetiva demonstração do prejuízo (...) Não tem sentido prático, diante desse quadro, anular tudo para que o juiz processante emita pronunciamento sobre a viabilidade inicial da acusação se já foi acolhida definitivamente". (STJ, HC 85.779/RJ, Rel. Ministra Maria Thereza de Assis Moura, 6 ${ }^{\mathrm{a}}$ T., j. 20.9.2012). 
relativa e que, mesmo que houvesse um eventual prejuízo à época, este não subsistiria mais em razão de uma sentença condenatória.

Por óbvio que a dinâmica descrita acima é apenas ilustrativa, e com ela não se pretende esgotar todos os casos em que haja ausência de motivação no momento do recebimento da denúncia. No entanto, revela-se útil para mostrar, ainda que de maneira extremada, que a teoria atual das nulidades, sobretudo com o tratamento que se tem dado ao instituto do "prejuízo", tem gerado um sistema processual disfuncional e altamente deturpado.

\subsubsection{Nulidade em função de incompetência de juízo}

Possivelmente uma das matérias mais confusas no tocante às nulidades é a que trata da competência de jurisdição penal. Imperioso reconhecer que grande parte desse problema resulta, como em tantos outros institutos que já se viu, da transposição direta de conceitos do processo civil, sem qualquer atenção às especificidades do processo penal. ${ }^{491}$

É comum a doutrina, chancelada na maior parte das vezes pela jurisprudência, estabelecer uma distinção entre incompetência absoluta e incompetência relativa. ${ }^{492}$ Assim como se definiu a separação entre os casos de nulidade, entende-se que a função jurisdicional atende, por vezes, o interesse público (cuja transgressão resultaria em incompetência absoluta) e, em outras situações, o interesse particular (cuja transgressão resultaria em incompetência relativa). Há, por assim dizer, regras de competência inafastáveis e intransponíveis, e outras que permitem uma mitigação, a depender do exame concreto de determinada relação processual. ${ }^{493}$

Convencionou-se o entendimento - frise-se: por mera importação de conceitos do processo civil ${ }^{494}$ - de que seriam normas de competência absoluta aquelas que tratam da distribuição ratione materiae, as que cuidam da distribuição entre juízes superiores e

\footnotetext{
${ }^{491}$ BADARÓ, Gustavo Henrique Righi Ivahy. A garantia do juiz natural no processo penal, cit., p. 613-614.

${ }^{492} \mathrm{Tal}$ ideia seria extraída diretamente do processo civil, que separa claramente entre competências relativas e absolutas. Sobre essa divisão, bem como acerca da confusão também naquela disciplina específica, de se transcrever a lição de Dinamarco (DINAMARCO, Candido Rangel. Instituiçães de direito processual civil, cit., v. 1, p. 452-453): "A ordem jurídica processual estabelece uma distinção entre regras de competência que comportam algum grau de flexibilização e outras que não comportam modificação alguma. Tal é o binômio representado pelas competências relativas e pelas absolutas, de grande significado prático e sistemático no trato geral da competência e que oferece dificuldades práticas interpretativas muito grandes na experiência concreta do processo."

${ }^{493}$ PACELLI, Eugenio. Curso de processo penal, cit., p. 263-264.

${ }^{494} \mathrm{~A}$ diferença reside na inexistência, no processo penal, de regras de competência com base no valor da causa.
} 
inferiores (competência hierárquica), bem como as que dispõem acerca da distribuição entre juízes do mesmo órgão judiciário (competência interna). De outra forma, seriam consideradas normas de competência relativa e, portanto, que tutelariam, acima de tudo, interesses das partes, aquelas que tratam da distribuição territorial. ${ }^{495}$

Em sendo assim, a incompetência territorial, caso não suscitada em momento oportuno, segundo o entendimento predominante da matéria, será prorrogada. E mais: ainda que apontada a tempo, a incompetência territorial somente gerará nulidade, assim como ocorre com qualquer nulidade relativa, se a parte conseguir comprovar o prejuízo gerado pela distribuição equivocada do feito.

É assim que tem se pronunciado a jurisprudência. Apenas para ilustrar a questão, de se transcrever excerto de aresto proferido pelo Superior Tribunal de Justiça: "Sabemos todos que, no processo penal, as regras que presidem a atribuição territorial de competência consideram como foro comum o lugar da consumação da infração penal, em razão das maiores facilidades na coleta do material probatório disponível, bem como de sua produção em juízo, buscando-se otimizar o funcionamento da máquina judiciária e preservar o interesse público (...) Ademais, atentemos para o fato de que o próprio ordenamento jurídico trata a inobservância da competência territorial como causa de nulidade relativa, donde se impõe a demonstração do efetivo prejuízo à parte, o que não ocorreu na espécie." 496

Cumpre observar que o precedente acima, cujos termos encontram voz quase uníssona em outros tribunais, é mais uma demonstração de como inexiste uma teoria minimamente racional das nulidades no processo penal. Isso porque, um exame da matéria, sem se deixar influenciar por qualquer outro ramo do Direito, é apto a comprovar a ausência de um embasamento técnico para tais julgados.

Esclareça-se, de início, que o Código de Processo Penal, em seu artigo 564, I, dispõe que a incompetência do juiz gerará a nulidade. No aludido dispositivo legal - ou mesmo em qualquer outro do Código - não há uma distinção de grau entre as diferentes formas de incompetência, sendo certo que, a priori, nulo seria o ato praticado por juiz incompetente. Também, no mesmo sentido, não traz qualquer distinção o artigo 109, do

\footnotetext{
${ }^{495}$ GRINOVER, Ada Pellegrini; FERNANDES, Antonio Scarance; GOMES FILHO, Antonio Magalhães. As nulidades no processo penal, cit., p. 40.

${ }^{496}$ RHC 29.312/SP, $5^{\text {a }}$ T., Rel. Ministro Marco Aurélio Bellizze, j. 11.4.2013. Nesse mesmo sentido, ainda no STJ: HC 252.534/SP, $5^{\text {a }}$ T., Rel. Ministra Laurita Vaz, j. 8.5.2014; AgRg no REsp 1.265.395/RS, $5^{\text {a }}$ T., j. 18.3.2014. AgRG no AREsp 218.585/AL, 6 ${ }^{\text {a }}$ T., j. 20.8.2013.
} 
mesmo diploma legal, o qual permite ao magistrado reconhecer ex officio a incompetência, seja ela territorial ou não.

Daí porque, não se pode entender, sem que se recorra ao processo civil, a razão pela qual se considera a incompetência territorial uma nulidade relativa, ao passo que os outros casos de incompetência são classificados como geradores de nulidade absoluta. Essa distinção não encontra amparo no ordenamento jurídico, ao contrário do que asseveram, amiúde, as decisões judiciais.

Mesmo que se busque alguma justificativa nos critérios gerais estabelecidos pela doutrina para classificação das nulidades, ainda assim a diversidade de tratamento é inexplicável. Isso porque, não há como concordar com a tese de que as normas de competência territorial visem à proteção de interesses particulares, e por tal razão poderiam ser relativizadas. O argumento descaracteriza por completo a ratio da norma. ${ }^{497}$ Conforme adverte BADARÓ, "no processo penal, a competência do forum commissi delicti está inegavelmente ligada ao interesse público da correta prestação jurisdicional, não faltando situações em que tal critério decorre até mesmo de norma constitucional." ${ }^{498}$

De mais a mais, deslocar a competência de uma comarca para outra não configura apenas um erro sanável, desprovido de correlação com o interesse público. Antes, atinge diretamente o juiz natural, que como garantia fundamental não pode ficar sujeito à discricionariedade e ao bom senso dos representantes do Poder Judiciário. ${ }^{499}$ Segundo escólio de AURY LOPES JUNIOR, “as pessoas têm o direito fundamental de serem julgadas por um juiz competente em razão da matéria, pessoa e lugar e cujas regras estejam previamente estabelecidas."

E com a relativização da incompetência territorial, novamente transfere-se a problemática para a questão do prejuízo. Nesse sentido, exige-se que a parte (normalmente o acusado) comprove de que forma foi prejudicada em virtude de a ação penal tramitar em foro incompetente. ${ }^{501}$ A rigor, o mandado de prisão expedido por magistrado de comarca

\footnotetext{
497، A justificativa para a tramitação do processo no local onde se consumou a infração penal é a de que o agente dever ser processado (e, eventualmente, condenado) no lugar onde perturbou a ordem jurídica e se fizeram sentir os efeitos de sua infração penal, com vistas a tranquilizar o meio social alarmado." (BRASILEIRO DE LIMA, Renato. Competência Criminal. Jus Podium: São Paulo, 2010, p. 472)

${ }^{498}$ BADARÓ, Gustavo Henrique Righi Ivahy. A garantia do juiz natural no processo penal, cit., p. 607.

${ }^{499}$ CHOUKR, Fauzi Hassan. Código de Processo Penal: comentários consolidados e crítica jurisprudência. São Paulo: Saraiva, 2014. p. 171.

${ }^{500}$ LOPES JÚNIOR, Aury. Direito processual penal e sua conformidade constitucional, cit., v. 1, p. 482.

${ }^{501} \mathrm{~A}$ título de exemplo, pois os julgados são inúmeros, TJSP: "Há nulidade absoluta, improrrogável e insuscetível de convalidação, tão somente pela incompetência em razão da matéria ou da pessoa, não em
} 
que não guarde qualquer relação com o delito apenas seria considerado nulo se o acusado lograsse êxito em comprovar um determinado prejuízo resultante do ato defeituoso.

Contudo, há de se fazer, uma vez mais, a pergunta óbvia: como demonstrar o efetivo prejuízo de ser julgado por juiz cuja competência não encontre amparo na legislação? Se o mero fato de se apontar a incompetência territorial do juiz constitui evidência insuficiente para caracterização do prejuízo, o que, então, poderia ser objeto de prova para comprová-lo?

Caberia, por exemplo, ao acusado ou ao Ministério Público lançar mão de argumentos aptos a demonstrar que o magistrado incompetente, que proferiu uma determinada decisão, era tecnicamente menos capaz de analisar o fato quando comparado ao juiz natural? Ou, ainda, seria razoável exigir do acusado uma prova de que o juiz voluntariamente decidiu pela manutenção do processo em sua comarca apenas para prejudicar a defesa? Alegar que a prorrogação da competência alterou a verdade real ou o julgamento final do feito seria suficiente para se aperfeiçoar o prejuízo, ou seria imprescindível demonstrar (provar) essa lesão concreta da parte? Mas de que maneira comprovar tais prejuízos?

Note-se que as indagações - obviamente exemplificadas por meio de casos extremados apenas para efeito didático - revelam uma situação esquizofrênica dentro do processo. Não é garantido ao jurisdicionado, por razão alheia à sua vontade, o juiz préfixado em lei, mas mesmo assim compete a ele a demonstração do prejuízo causado pelo próprio Poder Judiciário. E, como se não bastasse, o conteúdo desse prejuízo, além de desconhecido e obscuro, mostra-se quase impossível de ser reconhecido pelas Cortes brasileiras. $^{502}$

Não é difícil perceber que o reconhecimento da nulidade, também em matéria de incompetência, ficará submetido a uma análise subjetiva e altamente questionável por parte do julgador. Se não existirem parâmetros mínimos para definição e organização do que de fato constitui o prejuízo, nulidade será aquilo que o magistrado entender naquele caso

relação ao local do crime, situação em que há, em tese, nulidade relativa, passível de reconhecimento se demonstrado prejuízo efetivo, o que não se verifica nesta ação constitucional." (HC 205991813.2014.8.26.0000, 16 C., rel. Des. Newton Neves, 24.6.2014).

${ }^{502}$ Para se constatar a veracidade da afirmação acima lançada, importante remeter ao estudo de Antonio Tovo Loureiro (Nulidades e limitação do poder de punir: análise de discurso de acórdãos do Tribunal de Justiça do Rio Grande do Sul, cit., p. 53-54), o qual, após um levantamento empírico da matéria perante o Tribunal de Justiça do Rio Grande do Sul, concluiu que apenas $18 \%$ das nulidades suscitadas pela defesa foram reconhecidas pelos desembargadores. Por outro lado, sustenta o estudo, o Ministério Público obteve cerca de $65 \%$ de sucesso nos casos em que requereu a declaração da nulidade. 
concreto, sempre a depender de sua boa vontade para reconhecer o efetivo prejuízo às partes. $^{503}$

\subsubsection{Ausência de alegações finais (memoriais) defensivas ao final da instrução preliminar nos processos de competência do Tribunal do Júri}

Dentre as matérias abordadas de amostra para análise empírica da atual aplicação do sistema das nulidades, cumpre estudar algum vício de ato que estaria supostamente mais ligado ao "interesse particular". ${ }^{504} \mathrm{Na}$ realidade, de nada adianta lançar mão de duras críticas ao sistema atual, e eventualmente propor novas soluções, se os precedentes forem pinçados a dedo, com o propósito único de demonstrar a equivocidade do modelo.

Desta feita, optou-se por tecer algumas considerações a respeito dos efeitos jurídicos da ausência de alegações finais da defesa no encerramento da instrução da primeira fase do processo de júri popular. É dizer: analisar-se-á adiante se os argumentos finais a que faz remissão o artigo 411, $\S 4^{\circ}$, do Código de Processo Penal, são obrigatórios, ou, em virtude da oportunidade de serem deduzidas todas as teses defensivas em plenário, tal peça é prescindível. ${ }^{505}$ Reitere-se: a questão será objeto de estudo justamente porque diz respeito a um interesse, em tese, "da parte", o que, segundo a doutrina tradicional, geraria uma nulidade relativa.

Pois bem. Em termos genéricos, ao se lançar olhos nos dispositivos do Código de Processo Penal, notadamente naqueles concernentes às nulidades, verifica-se que não existe previsão expressa acerca da sanção processual em virtude da ausência da apresentação de memoriais pela defesa. De outro lado, ex vi dos artigos 564, III, d, c/c, 572, do CPP, depreende-se haver nulidade relativa para casos nos quais o Ministério Público deixe de se manifestar "em todos os termos da ação por ele intentada". ${ }^{506}$ Sobre a

\footnotetext{
${ }^{503} \mathrm{E}$, aqui, vale a pergunta já feita inúmeras vezes, inclusive por Aury Lopes Junior: “e quem nos salvará da bondade dos bons?"

${ }^{504}$ Importa repetir, para não haver dúvidas. Não existe, no processo penal, interesse eminentemente privado. No entanto, a ideia é apenas utilizar um exemplo ilustrativo, que possa trazer alguma confusão sobre interesses de parte, de forma a não restar dúvidas sobre a iniquidade aplicada pela atual teoria das nulidades.

${ }^{505}$ Como regra, as alegações finais são orais. No entanto, assim como ocorre nos processos comuns, o magistrado, vislumbrando a complexidade ou o número de acusados, poderá permitir que as partes apresentem suas alegações por escrito, daí porque estuda-se a sua ausência no presente tópico.

506“"A ausência de alegações finais ou memoriais do representante do Ministério Público, além de implicar violação de dever funcional, sujeita a sanções disciplinares, caracteriza nulidade prevista no art. 564, III, d, considerada de natureza relativa (art. 572, CPP)." (GRINOVER, Ada Pellegrini; FERNANDES, Antonio Scarance; GOMES FILHO, Antonio Magalhães. Nulidades no processo penal, 12. ed., cit., p. 193).
} 
ausência das alegações da defesa, em qualquer procedimento dentro do processo penal, o código é silente.

É necessário, portanto, voltar-se à jurisprudência para compreender se a peça defensiva é obrigatória na primeira fase do júri. A questão, vale ressaltar, não é pacífica e tem sido objeto de intensos debates nos tribunais pátrios. A ilustrar a controvérsia, há de se transcrever trechos de aresto do Superior Tribunal de Justiça, que demonstram com nitidez a dificuldade de se aplicar o modelo atual das nulidades ao caso concreto. Destaque-se que, no caso específico, o defensor do acusado apresentou as alegações finais antes da decisão de pronúncia, mas apenas para dizer que "nada tinha a alegar naquela fase processual".

O Ministro Sebastião Reis Júnior, a quem competia a relatoria do Recurso Especial ora em análise, e para o qual alegações finais efetivas da defesa é ato essencial ao processo (entendimento que restou vencido no julgamento), asseverou que "mesmo em se tratando da primeira fase do procedimento do Tribunal do Júri, as alegações finais são obrigatórias e devem demonstrar ao menos algum vínculo com o caso concreto, não podendo se resumir a uma peça vazia e de caráter formal, que poderia ser utilizada em qualquer processo.” E acrescentou: “Ao término da primeira fase do procedimento do Júri, pode o magistrado pronunciar, despronunciar, desclassificar a conduta para outro crime de competência do Juízo singular ou, inclusive, absolver sumariamente. Sendo assim, impõese que haja apresentação de alegações finais que veiculem defesa em sintonia com o caso concreto, ainda que de forma sintética."

De forma contrária, a Ministra Assusete Magalhães, seguida pelos demais ministros da $6^{\text {a }}$ Turma, entendeu que a falta das alegações finais por parte da defesa, na fase inicial do processo de delitos de competência do júri, não gera nulidade absoluta, já que "nos processos de competência do júri popular, até mesmo o não oferecimento de alegações finais, na fase acusatória, não é causa de nulidade do processo, pois o Juízo de pronúncia é provisório, não havendo antecipação de mérito da ação penal, tratando-se de mero juízo de admissibilidade, positivo ou negativo, da acusação formulada, para que o réu seja submetido ou não a julgamento, perante o Tribunal do Júri, juiz natural da causa." E conclui a ministra, citando outro precedente, que "corretamente intimada para apresentar as alegações finais, mas deixando de fazê-lo, descabe à defesa alegar nulidade a que deu causa. Ademais, é princípio fundamental no processo penal o da não declaração de

${ }^{507}$ RESP 1.373.259, Rel. Ministro Sebastião Reis Júnior, 6 6 Turma, j. 10.12.2013. 
nulidade do ato se dele não resultar prejuízo comprovado para a parte - art. 563 do CPP."

Consoante se verifica nas posições adotadas acima, a tradicional doutrina sobre nulidades é insuficiente para fornecer uma resposta minimamente racional em relação à problemática em questão. Fica evidente que a discussão deixa de girar em torno - ao contrário do que deveria ocorrer - dos elementos presentes para classificar a natureza da nulidade (se relativa ou absoluta), ou mesmo do que poderia ser classificado como prejuízo naquele caso concreto. Em verdade, o precedente revela que a linha argumentativa decisória está mais consubstanciada em "opiniões" sobre a importância da defesa técnica ao final da instrução, do que propriamente numa decisão com embasamento teórico-científico.

Se, de um lado, há o entendimento (vencido) segundo o qual o vício geraria a nulidade absoluta justamente porque a peça defensiva seria imprescindível para o regular desenvolvimento do processo, de outro, o voto vencedor sugere que o juízo de pronúncia seria apenas provisório, sendo dispensável a existência das alegações finais por parte da defesa. Desconhece-se, contudo, de onde nasce o lastro doutrinário ou técnico para justificar uma ou outra posição. A razão é simples: as bases sobre as quais se ampara o atual estudo sobre nulidades são incapazes de solucionar os mais comezinhos problemas da matéria.

Com efeito, segundo a tradicional doutrina sobre nulidades, seria necessário perguntar, num primeiro momento, se o ato viciado atenderia a interesses privados ou públicos, de modo a classificar a nulidade em absoluta ou relativa. Todavia, já nesse ponto reside um problema. Expor os argumentos técnicos da defesa antes de uma eventual decisão de pronúncia corresponde apenas a um direito renunciável da parte, ou seria esse ato um desdobramento da uma garantia fundamental - e, portanto, pública - do contraditório?

Essa problemática não é enfrentada pelos tribunais. Os julgadores evitam, na maior parte das vezes, entrar nessa discussão. Não por outra razão se afirmou acima que os precedentes sobre esse tema decorrem mais de "opiniões pessoais" do que propriamente resultado de uma análise meticulosa acerca da natureza do vício. Em outros termos, ou bem, por um lado, o magistrado entende que as alegações finais são essenciais antes de uma decisão de pronúncia, ou, por outro lado, não vislumbra a imprescindibilidade da peça, sob a justificativa de que haveria a oportunidade de se levantar todas as questões no transcorrer do julgamento em plenário.

${ }^{508}$ RESP 1.373.259, Rel. Ministro Sebastião Reis Júnior, 6 6 Turma, j. 10.12.2013. 
Convenha-se: se levadas a cabo as lições da doutrina tradicional sobre nulidades, difícil seria deixar de caracterizar o vício como nulidade absoluta. A uma, porque a possibilidade de a defesa apresentar suas alegações finais, em contraposição àquelas ofertadas pela acusação, é corolário das noções de contraditório e ampla defesa, garantias essas de índole constitucional. A duas, pela relevância monumental ínsita à decisão que leva um cidadão a júri popular. A inexistência da peça defensiva, nessa fase processual específica, impede que o juiz togado tome conhecimento, pela última vez, de argumentos que eventualmente poderiam evitar uma sessão plenária.

Contudo, mesmo diante dessas evidências, a jurisprudência, de forma maciça, se inclina no sentido de atribuir natureza de nulidade relativa ao vício em comento. ${ }^{509}$ Deve-se creditar tal posicionamento, reitere-se, a uma opinião generalizada, e repetida quase cegamente, de que o juízo de pronúncia é sumário e precário, não havendo, por isso, obrigatoriedade de apresentação das alegações ao final da primeira parte do procedimento do júri.

E se assim é, todas as discussões giram em função do prejuízo gerado pelo ato atípico. E, à semelhança do que ocorre nos outros tópicos examinados na análise casuística, os casos de ausência de alegações finais no júri endossam a tese de que o atual modelo de nulidades se revela inadequado e insuficiente frente aos mais diversos defeitos processuais observados na prática. Denota-se que as categorias formadoras da base principiológica das nulidades processuais penais não são suficientemente sólidas; ao revés, ficam à mercê de uma alta carga de discricionariedade do juiz.

\footnotetext{
${ }^{509}$ O Supremo Tribunal Federal já se debruçou sobre o tema. HC 106.074/PR, Rel. Ministro Marco Aurélio, $1^{\text {a }}$ T. j. 8.10.2013: “A competência territorial é relativa, prorrogando-se caso não seja ajuizada exceção de incompetência (...) No caso concreto, ajuizada a exceção de incompetência, e julgada esta improcedente, forçoso é concluir-se no sentido de que a matéria encontra-se preclusa."
} 


\section{A DEFINIÇÃO DO PREJUÍZO - UMA PROPOSTA DE RACIONALIZAÇÃO DO PROCESSO DECISÓRIO PARA IDENTIFICAÇÃO DAS NULIDADES}

O trabalho, até aqui, buscou examinar o atual cenário jurídico que envolve as nulidades processuais penais. Resta claro que há uma evidente dissociação entre a concepção atual (pós-Constituição de 88) de instrumentalidade do processo penal e a maneira como está sendo aplicada a teoria das nulidades por nossas cortes. Um dos motivos para essa "crise das nulidades", conforme já se viu, surge justamente pelo uso indiscriminado da regra pas de nullité sans grief, sem que se estabeleça, por outro lado, o que de fato configura o "prejuízo" nas nulidades.

Nesse aspecto, preciosas as lições de JACINTO DE MiRAndA Coutinho quando assevera que "prejuízo, em sendo um conceito indeterminado (como tantos outros dos quais está prenhe a nossa legislação processual penal), vai encontrar seu referencial semântico naquilo que entender o julgador; e aí não é difícil perceber, manuseando as compilações de julgados, que não raro expressam decisões teratológicas."

De fato, mostra-se temerário permitir que a viga mestre do sistema de nulidades flutue ao sabor das mais diversas interpretações, sendo elas desprovidas de critérios mínimos para aferição de sua legalidade. ${ }^{511}$ Mas, se de um lado, é certo que se pode atribuir à jurisprudência parcial responsabilidade pela confusão a respeito do tema, de outro, não é menos verdade que a doutrina pouco esforço faz para diminuir a vagueza e obscuridade no uso do termo "prejuízo" no âmbito das nulidades.

O presente capítulo, portanto, terá o objetivo de propor critérios jurídicos aptos a delinearem com mais precisão o conteúdo do "prejuízo". 512 Por óbvio que, para cumprimento desse mister, não basta apenas definir o termo para efeitos processuaispenais, mas antes, e sobretudo, imperioso que se examine em que circunstâncias é exigida

\footnotetext{
${ }^{510}$ COUTINHO, Jacinto Nelson de Miranda. Introdução aos princípios gerais do processo penal brasileiro. Revista de Estudos Criminais, Porto Alegre, v. 1, n. 1, p. 44, 2001.

511،Además, permite discernir criterios claros, imprescindibles para un área tan sensible del proceso penal, siempre sujeta a los vaivenes de la tolerancia cultural, por una parte, y a los principios del respeto intangible a la persona humana, por la otra." (BINDER, Alberto. El incumplimiento de las formas procesales, cit., p. 54).

${ }^{512}$ Nas palavras de Luhmann (Legitimação pelo procedimento, cit., p. 50), o que se busca nesse capítulo é uma "legitimidade racional" para a decisão de aferição do prejuízo nas nulidades.
} 
a demonstração do prejuízo, quais são os requisitos para sua caracterização, e a quem compete o ônus de comprová-lo.

Insta frisar novamente que o trabalho não tem a pretensão de propor uma nova categorização do sistema das nulidades, mas sim detectar lacunas que, na legislação em vigor, impedem um melhor desenvolvimento de uma estrutura teórica suficiente para resolução dos problemas práticos. Portanto, deixando de lado qualquer discussão acerca da necessidade de alteração do atual Código de Processo Penal, o que se objetiva é encontrar mecanismos, dada a realidade posta, para buscar uma maior uniformização de um tema tão controverso quanto o do prejuízo em sede das nulidades.

\subsection{Reflexões iniciais: a complexa sistematização de temas ligados ao vício processual e a equivocidade de focar o estudo na casuística}

Tarefa ingrata é tentar formular um modelo sistemático para aplicação do prejuízo. Por se tratar de matéria diretamente relacionada aos vícios do instrumento-processo, por mais desenvolvidas e herméticas que sejam as regras a ela atinentes, há de se reconhecer a impossibilidade de cobrir integralmente as hipóteses de sua incidência. ${ }^{513}$ É preciso, todavia, buscar parâmetros de racionalização da decisão que analisa o prejuízo nas questões relativas às nulidades processuais.

É evidente a dificuldade de se construir um modelo teórico apto a solucionar todo e qualquer caso, e nem poderia ser essa a pretensão do presente trabalho. ${ }^{514}$ Aliás, RoxIN traça com precisão os perigos de estruturar o Direito com base no pensamento sistemático. De acordo com o doutrinador alemão, a despeito de simplificar a interpretação normativa, a criação de modelos sistemáticos reduz, muitas vezes, a possibilidade de resolver a questão enfrentada pelo problema concreto. Ademais, o pensamento sistemático, ao tentar ordenar de maneira transparente todos os fenômenos atrelados a um campo específico,

\footnotetext{
${ }^{513}$ Sobre a dificuldade de tratar do tema das nulidades, Galeno Lacerda (Despacho saneador, cit., p. 69), citando Batista Martins, assenta que é "quase impossível prever, por mais acurada que seja a diligência, todas as formas derivadas ou secundárias que podem assumir os atos típicos do processo para atender às contingências de cada caso concreto. As sanções de nulidade da lei poderiam, assim, não bastar para a tutela da justiça nos caos em que o defeito de um ato, embora não considerado pelo legislador, fosse, não obstante, de tal ordem que pudesse tolher o efeito jurídico a que era destinado."

${ }^{514}$ Calmon de Passos (Esboço de uma teoria das nulidades aplicadas às nulidades processuais, cit., p. 75-76), com precisão, aponta uma das razões da dificuldade de se elaborar um modelo teórico em assuntos ligados ao processo penal: “O direito material é, pois, uma 'qualificação' de forma de comportamentos. Já o direito processual é a 'predeterminação' de uma forma de comportamentos.”
} 
apoia-se em pontos de vista reitores, e acaba por eleger conceitos demasiadamente genéricos. $^{515}$

Por outro lado, restou nítido nos capítulos anteriores que deixar a aplicação das regras de nulidade ao alvedrio absoluto do magistrado tem gerado um cenário caótico e imprevisível para o jurisdicionado. Com efeito, por maior a dificuldade de se propor um modelo racional no tema das nulidades, é imprescindível superar a ideia Kelsiana de que a decisão judicial nasce de um ato de vontade, mormente porque acaba por outorgar ao julgador uma discricionariedade exacerbada. ${ }^{516}$

De nada adiantará afirmar que a regra do pas de nullité sans grief constitui a ideia reitora do sistema de nulidades se não houver uma reflexão daquilo que, à luz do processo penal, configura o prejuízo. De igual forma, inexistirá evolução alguma no pensamento,se houver a insistência na teoria de que o juiz, diante de um caso concreto, possa sanar o vício com base na sempre propalada "livre convicção". 517

A realidade hodierna confere ao magistrado poderes ilimitados para afastar o prejuízo, sem ter de expor fundamentadamente as razões para fazê-lo. Na esteira de LENIO STRECK, a decisão "não pode ser entendida como um ato em que o juiz, diante de várias possibilidades possíveis para a solução de um caso concreto, escolhe aquela que lhe parece mais adequada. Decidir não é sinônimo de escolher." ${ }^{, 518}$ É dizer: a consciência do julgador, a despeito de sua parcial relevância, não pode ser único fator a justificar o conteúdo da decisão. ${ }^{519}$

Para superar esse modelo decisionista - o qual encontra sua base teórica no positivismo do início do século XX - parece ser necessário criar os contornos para a correta aplicação do prejuízo no âmbito das nulidades. É preciso, para além do conteúdo, cuidar das regras relativas ao "caminho" para que a decisão se torne legítima. A observação dessas diretivas, como ensina ALEXY, certamente não garantirá a certeza de um

\footnotetext{
${ }^{515}$ ROXIN, Claus. Derecho penal. Trad. Manuel Luzon Pena, Miguel Diaz y Gargia Conlledo e Javier de Vicente Remesal. 2. ed. Madrid: Civitas, 1997. t. 1, p. 214. O autor ainda cita mais um perigo do pensamento sistemático, qual seja, a pouca importância que se dá à justiça em um caso concreto.

${ }^{516}$ Cf. KELSEN, Hans. Teoria pura do direito, cit., cap. VIII.

${ }^{517}$ Digna de transcrição a lição do penalista Gimbernat Ordeig sobre a importância de a dogmática definir limites para aplicação do direito: "La dogmática jurídico penal, al señalar límites y definir conceptos, hace posible una aplicación segura y calculable del Derecho penal, y lo sustrae a la irracionalidad, a la arbitrariedad y la improvisación. Cuanto más pobre sea el desarrollo de una dogmática, tanto más imprevisibles serán la decisiones de los tribunales." (Problemas actuales de derecho penal y procesal. Salamanca: Bosch, 1971).

${ }^{518}$ STRECK, Lenio. O que é isto: decido conforme minha consciência? cit., p. 107.

${ }^{519}$ Nesse aspecto, cabe lembrar a lição de Eros Grau (Por que tenho medo dos juízes?: (a interpretação/aplicação do direito e dos princípios), cit., p. 89), para quem "o juiz, mesmo ao se deparar com hipóteses de lacunas normativas, não produz normas livremente. Qualquer intérprete, assim como todo juiz, estará sempre vinculado pelos textos normativos."
} 
resultado perfeito, mas sem dúvida fará com que aquele resultado se revista de uma racionalidade legitimadora. ${ }^{520}$

Adiante-se que, para cumprimento deste desiderato, o estudo sobre as regras de aplicação do prejuízo não pode estar vinculado a um rol de atos geradores de nulidade. Ou seja, não se utilizará, como premissa, hipóteses de nulidades processuais para, só então, examinar a incidência do prejuízo. Ao revés, as diretrizes de aplicação e mensuração do prejuízo devem encontrar substrato independentemente do caso a ser analisado casuisticamente pelo magistrado.

Não é despiciendo lembrar que normalmente os estudos relacionados às nulidades do processo penal, muito em função da própria disposição do CPP vigente, gravitam em torno de vícios específicos que, se cometidos no decorrer da persecutio criminis, poderiam levar à nulidade (v.g. ausência do corpo de delito nos crimes que deixam vestígios). Na prática, a análise do prejuízo não se dá em separado, como algo afastado da natureza do defeito, mas sim como algo automático, tudo a depender da ocorrência do vício.

A título de exemplo, de se levar em conta o caso da incompetência de foro. O que é objeto de estudo doutrinário, e naturalmente encontra eco na jurisprudência, são as hipóteses de incompetência (p. ex. ratione materiae, territorial, etc.), bem como suas consequências jurídicas. O prejuízo dependeria da natureza da incompetência. Trata-se de espécie de fórmula condicional, resumida em “se, então"; se presente uma incompetência por matéria, então o prejuízo é presumido.

Ocorre que, e é oportuno ressaltar, em se tratando de temas ligados a vício, o estudo consubstanciado apenas em hipóteses casuísticas revela-se temerário. ${ }^{521}$ Isso porque, por mais que se possa prever um determinado acervo (rol) de hipóteses de defeitos no âmbito do processo, é preciso reconhecer a impossibilidade de englobar, num estudo, todos os possíveis atos geradores de nulidade.

\footnotetext{
${ }^{520}$ ALEXY, Robert. Teoria da argumentação jurídica. Trad. Zilda Hutchinson Schild Silva. São Paulo: Landy, 2001. p. 181.

${ }^{521}$ Roxin o denomina de pensamento problemático. Sobre ele, e a impossibilidade de ser usado em substituição ao pensamento sistemático, o autor explica: "En vista de las erróneas evoluciones que según lo expuesto puede traer consigo igualmente el pensamiento sistemático, cabría pensar en buscar un método científico que parta más del problema concreto y que ofrezca posibilidades de resolverlo justa y adecuadamente partiendo del mismo (...) Pero la tópica no puede sustituir al pensamiento sistemático. En efecto, aquélla no sólo vuelve a renunciar a las ventajas prácticas de este, como la simplificación del examen del caso y ordenación de la materia verificable y que facilita la aplicación del Derecho." (ROXIN, Claus. Derecho penal. t. 1, cit., p. 216).
} 
E mais: sabe-se, por exemplo, que a ausência de citação do acusado é causa de nulidade absoluta (art. 564, III, e, CPP), sendo dispensável (porque, teoricamente, presumível) a demonstração do prejuízo. Por outro lado, há entendimento de que, ainda que defeituosa a citação, caso o acusado se faça presente no dia da audiência, a nulidade será relativa, cabendo à parte a demonstração do prejuízo. ${ }^{522}$ Relativa também será a nulidade da citação no mesmo dia do interrogatório. ${ }^{523}$

Porém, e se o caso concreto não retratar, com exatidão, os precedentes mencionados? Suponha-se que o acusado não seja citado, mas haja procurador constituído nos autos, considerar-se-á, nesse caso, a citação válida? E se o magistrado determinar a citação com hora certa do acusado e restar provado, posteriormente, que o vizinho que fora intimado deixara de transmitir as informações necessárias ao acusado? Conforme se verifica, as especificidades de cada caso concreto são inesgotáveis, sendo impossível prever, já de antemão e em abstrato, se o prejuízo é ínsito ou não ao vício. ${ }^{524}$

Destaque-se que essa peculiar dificuldade de abranger as inúmeras formas de descumprimento da ordem processual inviabiliza a estruturação casuística, minimamente segura, de um modelo de aplicação do prejuízo nas nulidades. Impende, portanto, formular diretrizes, ainda que abstratas, para trazer certa racionalidade decisória relativa ao tema. É o que se tentará realizar adiante.

\subsection{Para se construir um sistema de nulidades, é indispensável o prejuízo?}

No capítulo anterior, examinou-se a natureza do prejuízo em nosso sistema de processo penal, concluindo ser ele, à luz do atual ordenamento, um pressuposto para aplicação das nulidades. Entretanto, ao se principiar uma discussão relativa às matrizes para formulação de um modelo racional do processo decisório em matéria de vícios, cumpre agora refletir se a exigência do prejuízo é mesmo imprescindível - e salutar -em

\footnotetext{
${ }^{522}$ Por todos, no STJ: HC 161.312/SP, rel. Ministro Napoleão Nunes Maia, 5 ${ }^{\mathrm{a}}$ T., j. 22.3.2011; HC 131.849/MG, Min. Og Fernandes, $6^{\mathrm{a}}$ T., j. 15.2.2011.

${ }^{523}$ No STF: HC 104.648, rel. Ministro Teori Zavascki, $2^{\mathrm{a}}$ T., j. 12.11.13. No STJ: AgRg nos Edcl no RESP 1.197.551, rel. Min. Sebastião Reis Junior, $6^{\mathrm{a}}$ T., j. 24.4.2012. Esclareça-se que antes da vigência da Lei $11.719 / 08$, o interrogatório do réu era o primeiro ato do processo, razão pela qual se discutia a nulidade da questão aventada.

${ }^{524}$ A problemática da classificação das nulidades não é restrita ao Brasil. No tocante à Italia, Giuseppe Fanuli (Le nullità nel processo penale, cit., p. 39) explica "L'opera di qualificazione non sempre è correttamente compiuta. Anzi, asasi spesso, persino nella giurisprudenza della Corte regolatrice coesistono indirizzi contrapposti. La sussunzione delle imperfezioni processuali nelle categorie sopra enucleate può apparire non agevole."
} 
todo e qualquer sistema de nulidades, ou se, por outro lado, haveria possibilidade de se pensar em invalidades desvinculadas da ideia de prejuízo.

A pretensa discussão não pode ser levada adiante sem antes lembrar o que foi examinado no primeiro capítulo. O processo penal não é, e nem pode ser, um fim em si mesmo; há de assumir função de instrumento-constitucional contra eventuais abusos do poder público, e somente a sua estrita observância legitimará a imposição de uma sanção criminal. ${ }^{525}$ Por via de consequência, as formas, responsáveis por conferirem contornos aos atos processuais, devem da mesma maneira se revestir de instrumentalidade, pois, caso contrário, teríamos que aceitar o retorno do culto ao formalismo, insustentável nos dias de hoje. $^{526}$

De fato, fosse a forma um fim em si mesma, dúvida não existiria sobre a dispensabilidade da demonstração do prejuízo. Eventual deformidade do ato processual levaria, inequivocamente, à declaração da nulidade, já que a própria função do processo restaria comprometida. Porém, afastada essa ideia, forçoso analisar o prejuízo sob outro ângulo, recorrendo, primeiramente, ao direito comparado para verificar a (des)importância da regra do prejuízo no âmbito das nulidades.

No processo penal italiano, à época do antigo Código Rocco (que serviu de modelo para redação do atual CPP brasileiro), a consecução da finalidade do ato figurava como sanatória geral e genérica do vício processual. Durante a vigência de tal diploma, esclarece GABRIELLA DE PAOLO, havia não somente uma relativização de toda e qualquer nulidade, mas uma incansável preocupação de elaborar novas fórmulas sanatórias para que nenhum ato inválido pudesse permanecer sem remédio. ${ }^{527}$ A nulidade somente era declarada se houvesse a demonstração de um prejuízo efetivo, e este apenas era reconhecido quando a parte demonstrasse que o ato não atingira sua finalidade. Caso contrário, incidia-se a cláusula sanatória.

\footnotetext{
${ }^{525}$ Nesse ponto, vale transcrever a advertência de Ricardo Gloeckner: "Do contrário, esperar do processo penal impulsos que respondam por uma proatividade do sistema punitivo corresponderia a alimentar os delírios persecutórios de um Manzini e de um Rocco ou ainda acreditar num direito penal da vontade de um Mezger." (Nulidades no processo penal: introdução principiológica à teoria do ato processual irregular, cit., p. 44).

526، A forma, o lugar e o tempo dos atos processuais são determinados com critério teleológico, isto é, para o fim de assegurar certos bens jurídicos que a lei reputa politicamente necessários ou tecnicamente convenientes; por exemplo, a defesa do réu, a celeridade do processo. A forma é puramente sacramental; é meio, e não fim." TORNAGHI, Helio. Curso de processo penal, cit., p. 293.

${ }^{527}$ DI PAOLO, Gabriella. La sanatoria delle nullità nel processo penale, cit., p. 111, "Infatti, per l'estrema genericità della forma 'se l'atto ha egualmente conseguito lo scopo', risultò tutt'altro che agevole comprendere in che cosa consistesse il fatto (processuale) dell'avvenuto raggiungimento del fine, e con quali modalità tale fatto andasse provato.”
} 
Com o advento do novo Código (1988), houve a supressão da fórmula genérica que permitia sanar o ato que, ainda que impropriamente praticado, tivesse atingido sua finalidade. ${ }^{528}$ Em seu lugar, inseriu-se o artigo $183,1, b$, cuja redação prevê que "salvo disposição em contrário, a nulidade será sanada se a parte aproveitou de faculdade cujo exercício o ato omitido ou nulo é prefixado". ${ }^{529} \mathrm{Em}$ tese, restou alijado do processo penal italiano a sanatória geral da consecução do ato, bem como de eventual necessidade de demonstração do prejuízo. ${ }^{530}$

Contudo, no transcorrer dos últimos anos, a jurisprudência daquele país, mesmo não havendo dispositivo expresso nesse sentido, vem retomando a ideia de que a declaração de nulidade somente ocorrerá em casos nos quais a finalidade do ato não for atingida. E mais: para que o vício seja relevante (resulte em nulidade), é necessário que haja uma ofensividade concreta às partes envolvidas. ${ }^{531}$ A figura do prejuízo, portanto, ainda que sob a nomenclatura de "ofensividade concreta", volta a fazer parte da realidade do sistema processual italiano. ${ }^{532}$

O Código de Processo Penal chileno, considerado por abalizada doutrina como o mais avançado da América Latina, ${ }^{533}$ também não prescinde da regra do prejuízo. A despeito de dispor de um sistema de nulidades mais consentâneo com um processo penal

\footnotetext{
${ }^{528}$ Consta que com as discussões em torno do novo projeto do CPP Italiano, para reformar o Código Rocco, surgem três grupos distintos para sugerir qual destino conferir à fórmula da finalidade do ato. O primeiro, $\mathrm{o}$ grupo "abolicionista", liderada por Leone, defendia a supressão da fórmula do Código. O segundo, os "conservadores", pretendiam manter a fórmula aberta até então em vigor. E por último, os "reformistas", que buscavam a substituição da formula codificada no art. 187, 3 - considerada excessivamente vaga e de dúbia compatibilidade com o princípio da taxatividade - com a previsão de poucos casos de atingimento da finalidade. Prevaleceu essa terceira corrente.

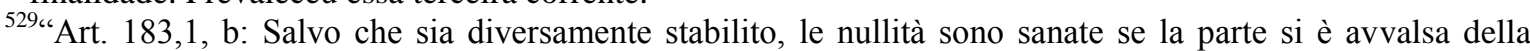
facoltà al cui esercizio l'atto omesso o nullo è preordinato."

${ }^{530}$ Clelia Iasevoli explica que a nova redação conferiu uma roupagem mais concreta e objetiva à ideia de finalidade do ato: "La conferma si rinviene nel corpus organico dele regole della sanzione, ove non si riscontra il riferimento testuale allo scopo, avendo il legislatore privilegiato la locuzione della 'facoltà al cui esercizio l'atto omesso o nullo è preordinato' (art. 183 lett. B c.p.p.). Quindi, l'ídea di scopo - che vi si rintraccia - è concreta ed ha natura oggetiva, in quanto predeterminata nella strutturazione della tipologia del modello, cioè nel momento dell'attibuzione di un determinato valore giuridico e facoltà processuale." (La nullità nel sistema processuale penale, cit., p. 252).

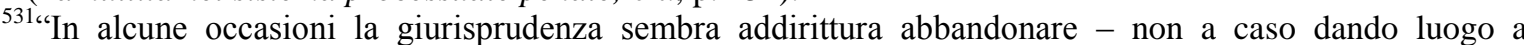
contrasti - l'esegesi del precetto, per introdurre um franco critério di offensività concreta del vizio quale condizione per la sua rilevanza. In questa prospettiva si determina un'evidente tensione con il tradizionale insegnamento per il quale le nullita ussistono independentemente dal concreto pregiudizio dell'interesse tutelato dalla norma violata." (FANULI, Giuseppe Luigi. Le nullità nel processo penale, cit., p. 177).

${ }^{532}$ De se transcrever decisão proferida naquele país que trata da correlação entre acusação e sentença e o necessário prejuízo para declaração da nulidade: "L'obbligo di correlazione tra accusa e sentenza non può ritenersi violato da qualsiasi modificazione rispetto all'accusa originaria, ma soltanto nel caso in cui la modificazione dell'imputazione pregiudichi la possibilità di difesa dell'imputato." (Cass. sez. IV, 15.1.2007 n. 10103, C.E.D. Cass. n. 236099).

${ }^{533}$ Importa lembrar que inúmeras diretrizes do Código Modelo de Processo Penal para Ibero-América foram incorporadas no ordenamento chileno.
} 
moderno, atrelado que está às garantias fundamentais constitucionais, ainda assim o diploma rege (art.159) que "sólo podrán anularse las actuaciones o diligencias judiciales defectuosas del procedimiento que ocasionaren a los intervinientes un perjuicio reparable únicamente con la declaración de nulidad."

Nos Estados Unidos da América, país que mantém uma tradição processual-penal intimamente atrelada ao Tribunal do Júri, até o ano de 1919, quase a totalidade dos julgamentos eram anulados em razão dos defeitos mais triviais. Os registros dão conta de que o amor ao formalismo era tamanho que houve um caso emblemático no qual o tribunal anulou julgamento de primeira instância porque a sentença havia condenado um indivíduo por estupro "contra a paz e dignidade estatal", em vez de dizer "contra a paz e dignidade do Estado". 534

Ocorre que, no ano de 1919, entra em vigor uma lei federal exigindo que os tribunais analisem os casos (autos) em sua integralidade, desprezando qualquer erro técnico que não afete substancialmente os direitos das partes. ${ }^{535}$ Surge, daí, a expressão "harmless error", que são as imperfeições ocorridas no decorrer de um julgamento, as quais, por não acarretarem dano às partes, deixam de gerar a anulação do ato. ${ }^{536}$

Ressalte-se que as discussões pretorianas acerca das limitações impostas pela regra do "harmless error" (iniciadas por Chapman v. California ${ }^{537}$ ) serão examinadas com maior profundidade adiante, até porque se revelam de extrema utilidade na construção de um modelo racional de decisão que analisa a incidência da nulidade em nosso país. Importa dizer, por ora, que a figura do prejuízo para aferição das nulidades encontra também solo fértil naquele país, evitando, por um lado, que julgamentos sejam anulados por defeitos

\footnotetext{
${ }^{534}$ State v. Campell, 109 S.W. 706, 707 (Mo 1908). Para maiores detalhes a respeito desse precedente, cf. WICHT, James Edward. There is no such thing as a harmless constitutional error: returning to a rule of automatic reversal, cit., p. 76. Eis um trecho do texto sobre o mencionado julgamento: "Instead, the appellate court reversed Mr. Campbell's conviction merely because the language at the end of the charging indictment alleged that the rape occurred 'against the peace and dignity of state' rather than the required 'against the peace and dignity of the state"'. Outro trabalho que trata do rigor com que os tribunais norteamericanos aplicavam as nulidades: "Early Nineteenth Century English and American courts liberally determined that even minor errors sufficiently infected trials so as to require 'reversals of conviction for mistakes unrelated to the guilt or innocence of the accused." (PATTON, William Wesley. To err is human, to forgive, often unjust. US Davis Journal of Juvenile Law \& Policy, v. 13, p. 102, 2009).

${ }^{535} \mathrm{Hoje}$, tal regra, com uma redação um tantodiferente, encontra-se prevista no art. 52 (a) do Federal Rules of Criminal Procedure: "Any error, defect, irregularity or variance that does not affect substancial rights must be disregarded".

536، Not all errors made at trial result in reversal or a defendant's conviction. If the error was harmless beyond a reasonable doubt - i.e., there is no reasonable possibility that the error contributed to the defendant's conviction - then the conviction may stand." (MARCUS, Paul; WILSON, Melanie. Criminal procedure. 18. ed. Chicago: Thomson-West, 2011. p. 212).

${ }^{537}$ Suprema Corte dos EUA, 386 U.S. 18, 1967.
} 
insignificantes, e, por outro, que nenhuma violação de direitos constitucionais seja permitida durante a persecução penal. ${ }^{538}$

Na Argentina, de forma semelhante, fala-se em pressuposto da transcendência, por meio do qual o defeito, para ser anulado, deve necessariamente afetar um interesse. ${ }^{539} \mathrm{~A}$ ausência de afetação do interesse tutelado pela norma significa a inexistência de um prejuízo à parte, carecendo de finalidade prática na declaração da nulidade. ${ }^{540}$

Conforme se verifica, a ideia do prejuízo nas nulidades, independentemente das variadas nomenclaturas que se dê a ela, está presente também nos ordenamentos processuais estrangeiros. Por esse ponto de vista, ao menos, parece ser extremante compatível um processo penal que se queira moderno e garantidor dos mais variados direitos do acusado com a exigência de que a deformidade do ato processual gere alguma forma de prejuízo às partes.

É certo que não se pode olvidar que as formas são, no processo penal, acima de tudo, uma garantia do acusado contra eventuais arbitrariedades perpetradas pelo Estado. ${ }^{541}$ Porém, isso não quer dizer, de maneira alguma, que essas mesmas formas não contenham um caráter teleológico; uma finalidade própria. É a verificação do prejuízo que conferirá, em última instância, ao tema das nulidades o aspecto finalístico do ato processual. Por isso, de forma acertada, SAlo de CARVAlHo e Antonio Tovo Loureiro ponderam que "a exigência do prejuízo concreto do descumprimento formal é coerente com a teoria funcional-garantista das formas processuais, porquanto consiste em ideia que transcende ao precitado binômio forma-violação, buscando a consequência concreta do ato viciado. Não

\footnotetext{
538، At its most basic, harmless error analysis represents an accommodation between a criminal defendant's interest in receiving a remedy for the violation of a constitutional right and the state's interest in preserving convictions where the error did not affect the outcome of the trial." (BLUME, John; GARVEY, Stephen. Harmless error in Federal Habeas Corpus After Brecht v. Abrahamson. Wm. \& Mary Law Review, v. 35, n. 163, p. 183, 1993).

${ }^{539}$ “"Coincide la doctrina en que la base fundamental de la estimativa de finalidad es el funcionamiento de la garantía general del debido proceso." (CREUS, Carlos. Invalidez de los actos procesales penales, cit., p. 20). Porém, o doutrinador argentino Gabriel Di Giulio (Nulidades procesales, cit., p 130) lembra que a definição do pressuposto da transcendência também não ficou imune a críticas naquele país, tendo em vista a falta de interesse particular no processo penal (já que este é público), bem como o risco de deixar o cumprimento das formas à mercê dos interesses das partes.

${ }^{540}$ Cite-se excerto de julgamento proferido pela Suprema Corte de Buenos Aires: "Para llegar al desenlace de la nulidad de un acto es condición esencial que exista perjuicio y por consiguiente interés tutelable de quien requiere que se la decrete." (SCBA, p. 51.114. j. 30.12.93).

${ }^{541} \mathrm{E}$ isso não é de hoje. Não se trata apenas de entendimento fruto do moderno garantismo penal. Note-se que João Mendes Júnior (MENDES JÚNIOR, João. O processo criminal brazileiro, cit., v. 1, p. 5) já em 1901: "As leis do processo são o complemento necessário das leis constitucionaes; as formalidades do processo são as actualidades das garantias constitucionaes. Si o modo e a forma da realisação dessas garantias fossem deixados ao critério das partes ou à discrição dos juízes, a justiça marchando sem guia, mesmo sob o mais prudente dos árbitros, seria uma ocasião constante de desconfianças e surpresas."
} 
obstante, a maneira como vem sendo exigida a demonstração de prejuízo na praxe judiciária indica que este critério está a serviço da cultura formalista-dogmática de inspiração inquisitória." 542

Conclui-se que o problema - e esse, é inegável, existe - na sistemática das nulidades não está na categoria do prejuízo, mas, sim, na forma como ela vem sendo entendida amiúde por nossas cortes. Suprimir a regra do prejuízo em nada alterará o atual caos teórico e casuístico que se instalou no tema das nulidades, pois o problema não se encontra em sua existência, mas, antes e sobretudo, na ausência de critérios para sua aplicação. $^{543}$

De certo modo, mutatis mutandis, a exigência do prejuízo, no campo das nulidades, poderia ser assemelhada ao conceito de "ordem pública", no tema relativo às prisões cautelares. Apesar das críticas à indeterminação do termo "ordem pública", parece ser difícil manter um sistema penal que impeça, em absoluto, qualquer prisão motivada por razões materiais. Se não for a ideia de "ordem pública", outra semelhante tomará seu lugar com intuito de prevenir, excepcionalmente, a liberdade de indivíduos por motivos além daqueles puramente processuais. ${ }^{544}$ Transportando a questão para a seara das invalidades, forçoso que se tenha algum mecanismo apto a conferir um aspecto finalístico aos atos processuais. De idêntica forma, se não for a ideia de prejuízo, outro termo tomará seu lugar para cumprimento dessa função. O esforço deve ser, tanto em matéria de nulidades quanto de prisão provisória, no sentido de delimitar tais conceitos e não de excluí-los.

\footnotetext{
${ }^{542}$ CARVALHO. Salo de; LOUREIRO, Antonio Tovo. Nulidades no processo penal e Constituição: estudo de casos a partir do referencial garantista, cit., p. 530.

${ }^{543}$ De opinião diversa, Aury Lopes Júnior: "Querem salvar a categoria do prejuízo? Difícil, senão até, desnecessário." (Sistema de nulidades 'a la carte' precisa ser superado no processo penal. Consultor Jurídico, São Paulo, 05 set. 2014. Disponível em: <http://www.conjur.com.br/2014-set-05/limite-penal-sistemanulidades-la-carte-superado-processo-penal>. Acesso em: 10 set. 2014). Na visão de Fauzi Choukr, o conceito de prejuízo está influenciado pela cultura inquisitiva e não se mostra largamente sensível aos valores constitucionais. (Código de Processo Penal: comentários consolidados e crítica jurisprudência, p. 761).

${ }^{544}$ Para um exame aprofundado sobre essa questão específica da custódia cautelar fundada na ordem pública, cf. MORAES, Mauricio Zanoide de. Presunção de inocência no processo penal brasileiro: análise de uma estrutura normativa para a elaboração legislativa e para a decisão judicial, cit., p. 382-390. Após analisar as diferentes posições acerca do assunto, o autor conclui não ser sugerível suprimir o conceito de ordem pública', mas sim criar limites para sua aplicação. Vale, nesse ponto, a transcrição de trecho do trabalho: “O presente trabalho, por aceitar a ideia de 'conteúdo essencial relativo', não propõe a exclusão do conceito de 'ordem pública', mas sugere o estabelecimento de três requisitos cumulativos como proposta inicial de debate para a delimitação mais segura no exame crítico do conceito. Delimitá-lo por parâmetros fixados pela doutrina e pela jurisprudência não significa engessá-lo de forma a não permitir sua análise casuística, o que é impensável para o estabelecimento de uma 'relação condicionada de precedência'. O que se deseja é fornecer padrões mínimos fora dos quais há ilegalidade (por abuso ou excesso) na utilização daquele conceito de 'ordem pública'.” (p. 389).
} 
Há de se reconhecer que, salvo se defendermos um modelo de nulidade extremamente formalista (no qual o mínimo deslize acarretaria a nulidade), parece ser difícil imaginar um ordenamento desprovido de critérios teleológicos nessa matéria. Por isso, ainda que se alije do processo penal a ideia do prejuízo nas nulidades, certamente tomaria seu lugar outra fórmula (e.g. ofensividade concreta, consecução do ato, etc.) apta a criar uma "ponte", necessária e salutar, entre a questão dos vícios e a instrumentalidade do processo. ${ }^{545}$

Nulidade sem prejuízo, de fato, não existe. Independentemente das classificações doutrinárias que se pretenda conferir ao sistema de nulidades, pouco importando se de nulidade absoluta ou relativa se esteja a falar, a verdade é que a anulação do ato processual impõe a ocorrência de um prejuízo. ${ }^{546}$ Evidente que, em determinados casos, esse prejuízo não necessariamente precisa ser comprovado, já que ínsito ao próprio vício, mas daí não se pode concluir que ele não esteja presente. É por tal razão que se sustenta, em consonância com o artigo 565, do Código de Processo Penal, que o prejuízo constitui pressuposto para declaração da nulidade.

Reforce-se que esse entendimento, de maneira alguma, enfraquece o papel da defesa - ou mesmo as garantias do acusado - dentro do processo; antes, ele o fortalece. Hoje, o que existe é uma discricionariedade endêmica no tema das nulidades. ${ }^{547}$ De nada adianta sustentar que é desnecessário o exame do prejuízo nas nulidades absolutas, achando que dessa forma se poderia garantir um processo mais justo ao acusado, se em verdade não existe um consenso sequer sobre quais as hipóteses de nulidade absoluta. Aliás, não raras são as decisões que, mesmo diante de uma atipicidade teratológica,

\footnotetext{
${ }^{545}$ Ainda que em sede do processo civil, Bedaque (Efetividade do processo e técnica processual, cit., p. 448) faz essa interligação entre o prejuízo e o aspecto teleológico da forma ao aduzir que "finalidade e prejuízo são ideias fundamentais à compreensão do sistema das nulidades processuais. Embora ambas possam representar fenômenos distintos, sua aplicação como mecanismos de determinação de relevância, ou não, da atipicidade do ato processual acaba por equipará-las, ao menos no que se refere aos resultados obtidos."

${ }^{546}$ É por isso que tem razão Gustavo Badaró ao asseverar que "toda nulidade exige um prejuízo. Há casos em que o prejuízo é evidente. No entanto, isso não se confunde com a não ocorrência do prejuízo, apenas sendo desnecessário demonstrá-lo. Excepcionalmente, mesmo em uma das hipóteses em que a lei considere que haverá nulidade absoluta, se for demonstrado que a atipicidade não causou prejuízo, o ato deverá ser considerado válido." (Processo penal, cit., p. 578).

${ }^{547}$ De certa forma, há de se concordar com Aury Lopes Junior: "Hoje no Brasil quando um ato é nulo? Quando o Tribunal quiser, para quem ele quiser e com o alcance que ele quiser. Essa é a verdadeira ditadura judicial vivenciada hoje. No espaço impróprio do casuísmo, os tribunais praticam o (ilegítimo e antidemocrático) decisionismo." (Sistema de nulidades 'a la carte' precisa ser superado no processo penal, cit., p. 4).
} 
desconsideram o caráter absoluto da nulidade, e exigem que a parte comprove o prejuízo. $^{548}$

É possível concluir, portanto, que a saída não reside na extirpação do prejuízo em sede de nulidades, mas no aprofundamento de seu significado. Na medida em que houver uma reflexão minuciosa concernente às diretrizes para aplicação do artigo 565 do Código de Processo Penal, restará claro que o cenário de insegurança que paira sobre o tema de nulidades deve ser creditado, em grande escala, ao descaso com o qual tem sido tratada a categoria do prejuízo pelos estudiosos.

\subsection{A desvinculação do prejuízo da ideia de "verdade substancial" ou "decisão da causa": a superação do subjetivismo inquisitório do artigo 566, do CPP}

A ausência de parâmetros objetivos para aplicação do pressuposto do prejuízo tem causado males inquestionáveis ao processo penal. Provavelmente o mais perigoso deles seja a crescente correlação que se faz entre o artigo 563 e o 566, ambos do Código de Processo Penal. É dizer: conclui-se, com frequência, que o segundo dispositivo legal mencionado seria um complemento do primeiro, de modo a entender que o vício somente gerará prejuízo quando influir na apuração da verdade substancial ou na decisão da causa. ${ }^{549}$

Sob essa perspectiva, a forma processual assume aspecto teleológico específico, sempre voltado à verdade ou ao veredicto final do processo. Prejuízo algum às partes se verificará, portanto, se o defeito, por maior que esse possa ser, deixar de criar óbice para um "bem maior", qual seja uma decisão final lastreada na verdade integral dos fatos apurados. ${ }^{550}$

\footnotetext{
${ }^{548}$ Não são poucos os casos que poderiam ser citados. No entanto, apenas como exemplo ilustrativo, de se transcrever ementa de precedente do Superior Tribunal de Justiça que entende ser o impedimento de um promotor de justiça uma nulidade relativa, impondo à parte a demonstração de eventual prejuízo: "Processual penal. Habeas Corpus. Art. 258 do CPP. Impedimento de membro do Parquet que atuou em segundo grau de jurisdição como custus legis. Nulidade relativa. Preclusão. Ausência de demonstração de efetivo prejuízo." (HC 38.823/RS, 5ª T., rel. Ministro Felix Fischer, j. 19.4.2005).

${ }^{549}$ Paulo Sergio Leite Fernandes e Geórgia Bajer Fernandes (Nulidades no processo penal, cit., p. 215), apesar de criticarem a redação do artigo 566, fazem o vínculo entre este dispositivo legal e o conteúdo do prejuízo: "Dentro do critério orientador do Código de Processo Penal, o artigo em exame [566] consagra a necessidade de pesquisar se o ato atingiu ou não sua finalidade, isto é, se não prejudicou a plenitude de atividade das partes, tolhendo, então, a apuração da verdade substancial. Intentou-se buscar equilíbrio perfeito entre a instrumentalidade do ato e a consecução dos objetivos para ele fixados. Pas de nullité sans grief. Em outros termos, não há nulidade sem prejuízo."

${ }^{550}$ Essa interpretação já não é de hoje. Cite-se, por exemplo, excerto de julgado proferido pelo Superior Tribunal de Justiça, que teve como relator o ministro Vicente Leal: "Em tema de nulidade no processo penal, as vigas-mestras do sistema assentam-se nas seguintes assertivas: a) ao arguir-se nulidades, dever-seá indicar, de modo objetivo, os prejuízos correspondentes, com influência da apuração da verdade substancial e reflexo na decisão da causa (CPP, art. 566)."
} 
Não se repetirão aqui todas as críticas já lançadas a respeito da concepção de verdade real (substancial) no âmbito do processo penal. ${ }^{551}$ Como é sabido, umbilicalmente relacionada a um modelo inquisitório de processo, ${ }^{552}$ a ideia de que é função do magistrado chegar a uma verdade absoluta acerca dos fatos retratados na persecutio criminis, para muito além de configurar uma utopia míope, foi (e ainda é!) responsável por justificar decisões as mais arbitrárias. ${ }^{553}$

Ao se transmitir o anseio (inalcançável) da "verdade real" para o campo das invalidades, não é necessário ir muito longe para perceber que a higidez do processo ficará à mercê de uma ideia abstrata, sem contornos, sujeita a todo tipo de manipulação. ${ }^{554}$ Eventual declaração de nulidade, nesse particular, dependerá de um subjetivismo exacerbado do julgador, o qual poderá, em maior ou menor escala, realizar uma interpretação conveniente do conteúdo do prejuízo. ${ }^{555}$

A ilustrar a problemática do tema, há de se recorrer a um caso concreto. Assuma-se, como hipótese, que um indivíduo seja preso em flagrante delito algumas horas após o cometimento de um suposto furto de um celular, sendo encontrado com ele um aparelho do mesmo modelo daquele subtraído da vítima. Após ser denunciado, o acusado nega a imputação contra ele formulada, afirmando que o celular era de sua propriedade. $\mathrm{Na}$ audiência de instrução e julgamento, o juiz determina o reconhecimento pessoal do acusado, mas o realiza em total inobservância dos preceitos do artigo 226 do CPP. A vítima reconhece o acusado. A defesa, ainda na audiência, alega a nulidade do ato

\footnotetext{
${ }^{551}$ Tal tema foi tratado com maior profundidade no capítulo 1.

${ }^{552}$ Mirjan Damaska, ao realizar um estudo sobre os modelos de processo penal, conclui que a ideia da busca da verdade está mais incrustrada na tradição do Direito continental: "In sum, the idea that criminal proceedings could justifiably be used for purposes other than those of establishing the truth and enforcing substantive criminal law is simply not part of the continental legal tradition." (DAMASKA, Mirjan. Evidentiary barriers do conviction and two models of criminal procedure: a comparative study, cit., p. 586).

${ }^{553}$ Não há como deixar de lembrar, nesse ponto, as palavras de Binder: "Por eso la verdad ha servido tanto para justificar los peores excesos del poder (la tortura sistemática) como para construir los límites que buscan prevenirlos (...) Cuando el proceso penal incorporó la idea de verdad consiguió un compañero de viaje tan interesante como molesto y conflictivo." (El incumplimiento de las formas procesales, cit., p. 61).

${ }^{554} \mathrm{~A}$ ilustrar a que ponto se pode chegar, oportuno citar um julgado do Tribunal de Justiça de São Paulo. Como é sabido, a súmula 11 do Supremo Tribunal Federal dispõe que só será lícito o uso de algumas em casos especificamente estabelecidos, sob pena de nulidade. Ao examinar uma hipótese de abuso no uso de algemas, a Corte paulista asseverou, dentre outros argumentos, que "referida nulidade também não influiu na apuração da verdade substancial ou na decisão da causa, não havendo porque ser declarada, de acordo com o artigo 566, do Código de Processo Penal.” (Revisão Criminal 0092894-44.2013.8.26.0000, rel. Des. Ruy Alberto Cavalheiro, $2^{\circ}$ Grupo de Direito Criminal, j. 26.8.2014).

${ }^{555}$ Merece reprodução a ponderação feita por Salah Khaled Júnior (Ambição de verdade no processo penal, cit., p. 119-120) sobre o efeito danoso do "mito da verdade real" no processo penal: "É evidente que existe algo chamado mito da verdade real e que embora a verdade real em si não passe de mera ilusão, o mito que a embasa exerce efeitos que, sem sombra de dúvidas, são reais (...) O mito da verdade real, apesar de presente e capaz de produzir efeitos concretos na realidade, não é reconhecido como mito, apesar da crítica a que é submetido.”
} 
processual (reconhecimento pessoal), reforçando tal arguição em sede de memoriais. O juiz, por fim, profere decisão condenatória, afirmando que o delito restou devidamente comprovado, mormente pelo fato de o objeto produto do furto ter sido apreendido em poder do acusado. Na própria decisão, o julgador afasta a alegação de nulidade do reconhecimento pessoal, pois, ainda que realizado em desacordo com o diploma legal, o ato em nada influiu na decisão da causa ou na apuração da verdade real (art. 566, CPP), razão pela qual não vislumbrava prejuízo à defesa do acusado (art. 563, CPP). ${ }^{556}$

Note-se que o exemplo citado, similar a inúmeros julgados prolatados diariamente por nossas cortes, é suficientemente apto a demonstrar o perigo de se associar o prejuízo ao resultado final do processo. Ora, a verdade é que basta o juiz, no bojo da sentença, afirmar que aquele vício não teve qualquer reflexo no processo decisório, para que isso, por si só, justifique a ausência de prejuízo às partes. ${ }^{557}$

Como saber, ainda recorrendo ao caso hipotético, que o vício ocorrido durante o reconhecimento pessoal não alterou em nada a decisão da causa? Se o ato tivesse sido realizado da forma como prescreve o Código de Processo Penal, e a vítima apontasse categoricamente pessoa diversa do acusado como o responsável pela conduta delituosa, seria possível desprezar tal prova no momento da sentença? É crível acreditar, com certo grau de razoabilidade, que o erro processual não influiu na apuração da verdade substancial?

De se ver que, a se aceitar a tese de uma inter-relação entre o prejuízo decorrente de um vício e a influência deste na resolução da causa, a forma se torna um mero acessório, desprovido de qualquer importância, cuja observância passa a ser facultativa. Com efeito, e levando ao extremo, poderá o magistrado flexibilizar toda e qualquer regra processual, desde que, ao final, afirme que aquele erro não alterou a apuração dos fatos. Em última instância, o rigor na observância dos atos processuais fica ao puro alvitre do julgador.

\footnotetext{
${ }^{556} \mathrm{~A}$ despeito de ser fictício, uma pesquisa na jurisprudência de nossos tribunais demonstra que o caso retratado acima, ainda que com outras particularidades, não é incomum. Tome-se, por exemplo, no STJ: AgRg no Ag 899.778/SC, 5 a T., Rel. Ministro Napoleão Nunes Maia, j. 28.2.2008.

${ }^{557}$ De forma idêntica é o ensinamento de Ricardo Gloeckner, para quem "basta ao juiz deixar de analisar a prova em sua sentença para que a nulidade daquele ato não possa ser suscitada. É ingênuo, para não dizer mal intencionado um sistema que espera do juiz que se afaste de suas pulsões e da própria contaminação psíquica com o ato nulo. Em realidade a apuração da verdade substancial será aferida na sentença. Ao revés de nulificar o processo, basta não analisá-lo na sentença. A não fundamentação da decisão nestes atos permite assim seguir acreditando que tal ato não contribuiu para a tomada de decisão." (Nulidades no processo penal: introdução principiológica à teoria do ato processual irregular, cit., p. 260).
} 
É preciso compreender que uma das funções da forma é garantir ao acusado o devido processo legal, e protege-lo de eventuais ilegalidades e arbitrariedades cometidas pelo Estado. ${ }^{558}$ Ao se assumir que um defeito, no transcorrer do processo, somente caracterizará um prejuízo na medida em que influenciar na decisão final da causa, ignora-se o papel fundamental da forma; aquilo que deveria afigurar-se como escudo protetivo do réu, transforma-se em mera burocracia estatal, cuja observância fica a critério absoluto do juiz.

Verifica-se, por consequência, um verdadeiro raciocínio deturpado de que o fim (decisão da causa e verdade substancial) justifica o meio (mitigação das formas processuais), como se inexistisse outro papel para a forma, que não o de apenas atingir uma decisão final. ${ }^{559}$ Ao se analisar o prejuízo apenas sob esse enfoque, tudo é remetido a uma decisão final. Embora não se desconheça que o procedimento constitui uma série concatenada de atos que visam à consecução de um ato final, é preciso lembrar que cada ato dessa cadeia tem, também, vida e finalidade própria. Não fosse somente isso, em última instância, atrelar o prejuízo à justiça da decisão final é também conferir ao magistrado, e não a lei, o poder para determinar qual o melhor caminho para atender à reconstrução da verdade..$^{560}$

Cumpre verificar que o artigo 566 do CPP, de índole inquisitiva, não resiste a uma interpretação conforme a Constituição-88. A figura do juiz como detentor de poderes ilimitados, a quem seria facultado temperar as regras processuais ao seu bel prazer, tudo a pretexto de buscar a "verdade substancial", não se revela mais consentânea com um modelo acusatório (ou, como querem alguns, misto) de processo penal. Todavia, ainda que se pretenda, por meio de uma interpretação salvacionista, não tornar letra morta a redação do dispositivo legal em comento, torna-se imperioso não fazer uma relação direta entre ela e o prejuízo.

Quando muito, a função do artigo 566 seria residual, mas totalmente desvinculada da regra do pas de nullité sans grief. Em outras palavras, se em um caso concreto, após uma decisão devidamente motivada, o juiz chegar à conclusão de que o vício não gerou prejuízo algum às partes, então passará a analisar se aquela deformidade tem o potencial de

\footnotetext{
${ }^{558}$ Calha, aqui, a citação de James Edward Wicht: "While criminal defendants may not be entitled to perfect trials, they do deserve proceedings free from Constitutional infirmity." (WICHT, James Edward. There is no such thing as a harmless constitutional error: returning to a rule of automatic reversal, cit., p. 75).

${ }^{559}$ Sobre a impossibilidade de atribuir uma só finalidade para o ato, João Conde Correia (Contributo para análise da inexistência e das nulidades processuais penais, cit., p. 71) aduz: "As normas processuais penais, como aliás todas as outras, nem sempre estabelecem, com clareza, qual o interesse jurídico protegido, nem quem é o seu titular, não sendo raro que tutelem, em simultâneo, diversas finalidades e uma infinidade de sujeitos."

${ }^{560}$ Antonio do Passo Cabral (Nulidades no processo moderno: contraditório, proteção da confiança e validade prima facie dos atos processuais, cit.) lembra que, ao mesmo tempo em que a ideia da instrumentalidade teve seus méritos, ela também atribuiu um aumento descompensado dos poderes do juiz.
} 
influir na decisão da causa. Porém, vale enfatizar, esse exame está condicionado à inexistência do prejuízo, e não se mistura ao próprio conteúdo dele.

Aliás, nesse ponto, há de se convir que a própria topografia dos dispositivos legais em questão não permite conclusão diversa. Deveras, o artigo 563 é o primeiro do Título "Das Nulidades" no Código de Processo Penal. Por sua vez, o artigo 566 somente é introduzido após o rol das hipóteses que levarão à nulidade absoluta (564). Fosse intenção do legislador que o significado do prejuízo mantivesse relação com a "verdade substancial" ou "decisão final da causa", teria certamente insculpido um dispositivo legal na sequência do outro, ou mesmo redigido tal determinação em um próprio artigo. ${ }^{561}$

Por essas razões, dignas de rechaço assertivas do tipo "não há falar em nulidade, uma vez que o depoimento não foi levado em consideração e sequer mencionado no decisum, ou seja, não influiu de modo algum na decisão da causa. (...) Assim, não havendo prejuízo à parte e não tendo tal depoimento influído na decisão da causa, a prefacial de nulidade deve ser afastada." ${ }^{, 52} \mathrm{Ou}$ ainda: "Prejuízos relevantes são aqueles que derivam de atos processuais nulos, mas com aptidão para influir na apuração da verdade ou do convencimento judicial". 563

Se é uma diminuição do grau de subjetividade - do imponderável - que se busca conferir ao modelo de nulidades, a associação direta entre prejuízo e apuração da verdade real (ou deslinde da causa) faz justamente o contrário; concede poderes ilimitados ao juiz para flexibilizar a forma processual com base em conceitos de inquestionável abstração. ${ }^{564}$

\subsection{Da necessidade de análise independente do prejuízo em relação às classificações das nulidades}

Já se ponderou, nos capítulos anteriores, que as categorias de nulidade relativa e absoluta precisam ser revistas. De fato, examinando o ordenamento pátrio, e mesmo recorrendo a estudos doutrinários, não é possível sequer concluir, sem certa

\footnotetext{
${ }^{561}$ O Código de Processo Penal do Chile, um dos poucos que ousaram buscar regulamentar o prejuízo, define o que é prejuízo no próprio artigo 159. Ou seja, do mesmo dispositivo legal em que se diz que não há nulidade sem prejuízo, é possível extrair o que é necessário para configuração daquele prejuízo.

${ }^{562}$ TJSC, Apel. Criminal 2009.015380-3, $4^{\text {a }}$ Câmara, rel. Jorge Schaefer Martins, j. 27.10.2011.

${ }^{563}$ PACELLI, Eugenio. Curso de processo penal, cit., p. 823.

${ }^{564} \mathrm{O}$ aumento da discricionariedade (arbítrio) em matéria de nulidades não passou despercebido pela doutrina argentina: "El criterio del arbitrio judicial (sistema judicialista) para estimar la incidencia del defecto de lacto en orden a la nulidad, fue reemplazado en la posterior evolución de los sistemas por la reducción de las hipótesis de declaración de nulidad a las previstas taxativamente por la ley, en normas específicas o en disposiciones genéricas (sistema legalista), pero últimamente este criterio se completa con el que puede ser una revivicación parcial del aquel arbitrio - aun que relativizado - en torno a la consideración de las finalidades del acto." (CREUS, Carlos. Invalidez de los actos procesales penales, cit., p. 20).
} 
indeterminação, o que difere uma de outra. ${ }^{565}$ Há quem diga, aliás, que essa classificação deveria ser extirpada da seara processual. ${ }^{566}$ Porém, demonstrar-se-á adiante que essa discussão, a despeito de sua relevância, não precisa ser levada a efeito no presente trabalho, haja vista que o estudo do prejuízo prescinde, num primeiro momento, de uma definição peremptória nesse sentido.

É cediço que usualmente a doutrina tem tratado a análise do prejuízo como algo dependente da classificação conferida ao vício. ${ }^{567}$ Assim, se o vício gerar uma nulidade absoluta, o prejuízo é presumido, ao passo que a nulidade relativa exigiria da parte a demonstração do prejuízo. Parte-se, portanto, da natureza do vício para, só então, examinar a ocorrência de algum prejuízo à defesa ou ao Ministério Público.

Fosse correta essa visão, necessário seria reconhecer a importância de lançar luzes, no presente trabalho, sobre uma possível reclassificação das nulidades, uma vez que a decisão a respeito da ocorrência ou não do prejuízo dependeria da categoria em que o vício se enquadrasse. Em outras palavras, dado um caso concreto, forçoso seria saber se a hipótese configuraria nulidade absoluta, pois as regras de aplicação do prejuízo (ex. quando ele seria presumido) estariam vinculadas a essa classificação inicial.

Ocorre que parece ser indiferente, para fins de estabelecer diretrizes para aplicação do prejuízo, conhecer a classificação da nulidade. Pouco importa, em verdade, empregando a categorização tradicional, se o vício é de tal grandeza a configurar uma nulidade absoluta, ou se, por outro lado, apenas atinge "interesses particulares", 568 o que geraria uma nulidade relativa.

Com efeito, não será a espécie da nulidade a responsável por determinar de que forma se verificará o prejuízo. Muito pelo contrário, este independe da classificação que se confira ao vício em um caso concreto, pois constitui pressuposto para a declaração de toda

\footnotetext{
${ }^{565} \mathrm{O}$ tema foi explorado, com maior profundidade, no capítulo 2, oportunidade na qual se analisou a imprecisão ligada às mais variadas distinções entre nulidade absoluta e relativa.

${ }^{566}$ Gloeckner (Uma nova teoria das nulidades: processo penal e instrumentalidade constitucional. 2010. Tese (Doutorado) - Faculdade de Direito da Universidade Federal do Paraná, UFPR, Curitiba, 2010. Disponível em:

<http://dspace.c3sl.ufpr.br/dspace/bitstream/handle/1884/24494/GLOECKNER,\%20RICARDO\%20JACOBS EN\%20-\%20Copia.pdf?sequence=1>) entende ser essa divisão artificial e contraproducente. Com enfoque maior no processo civil, Calmon de Passos assevera: "Gostaria de abordar o problema das chamadas nulidades absolutas e nulidades relativas no processo. Essa transposição de categorias de nulidades, já muito bem trabalhadas no direito privado, carece de adequabilidade no espaço do direito público, máxime no campo do direito processual.” (Esboço de uma teoria das nulidades aplicadas às nulidades processuais, cit., p. 141).

${ }^{567}$ Nesse sentido, cf. PACELLI, Eugenio. Curso de processo penal, cit., p. 813-817; NUCCI, Guilherme de Souza. Código de Processo Penal comentado. 8. ed., cit., p. 893-894.

${ }^{568} \mathrm{O}$ emprego das aspas se faz necessário, pois, conforme explorado ao longo de todo o trabalho, inexistem atos processuais que protejam somente interesses particulares.
} 
e qualquer nulidade. Por mais estranho que possa parecer tal assertiva, a vinculação do prejuízo à natureza da nulidade é uma invenção doutrinária, cuja reprodução irrefletida tem sido perniciosa para o avanço de um estudo mais aprofundado da regra pas de nullité sans grief. $^{569}$

Qualquer levantamento jurisprudencial sobre o tema revelará que, a despeito de se falar quase sempre em prejuízo, invocando ser ele imprescindível ao estudo das nulidades, nunca há uma análise concreta sobre como ele se caracteriza. É porque justamente o prejuízo vem, por um equívoco, sempre associado à natureza da nulidade, sendo atribuído mais importância ao fato de a invalidade ser absoluta ou relativa, do que propriamente à ofensividade concreta daquele vício. Verifica-se, usualmente, o seguinte padrão: a discussão gira em torno da classificação da nulidade; sendo ela absoluta, desnecessária a demonstração do prejuízo, por estar ele implícito (presumido) no próprio vício; sendo relativa, há a exigência de demonstração do prejuízo, mas o julgador se limita a dizer se ele está presente ou não, deixando de esclarecer como chegou àquela decisão.

Assim, o risco do atrelamento do prejuízo às diferentes categorias de nulidade, que consiste em justamente deixá-lo em segundo plano, dependente de uma análise anterior, quando, na realidade, deveria ser o contrário: é o exame do prejuízo que deve preceder qualquer outra decisão em matéria de nulidades, sendo certo que eventuais desdobramentos jurídicos do vício, estes sim, estão condicionados à existência de certa ofensividade. ${ }^{570}$

Destaque-se, por exemplo, que a presunção da existência do prejuízo não deve estar relacionada à espécie de nulidade. É dizer: o prejuízo não se presume, em determinados casos, porque a nulidade é absoluta. Antes, essa presunção, se ela existir, se constitui antes e independentemente do fato de caracterizar o defeito uma nulidade absoluta.

Imperioso dizer, nesse sentido, que existem vícios de extrema gravidade os quais eventualmente podem não gerar qualquer prejuízo às partes, ao passo que outros, aparentemente menos lesivos, causam um prejuízo inquestionável e de necessária

\footnotetext{
${ }^{569}$ Por óbvio que essa vinculação entre categorias de invalidade e prejuízo não ocorre exclusivamente em nosso país. Ela vem de há muito, sobretudo, em função da doutrina desenvolvida em torno do Código Rocco (1930) italiano, cf. MANZINI, Vincenzo. Trattato di diritto processuale penale italiano, cit., p. 127131. No entanto, a maior parte dos países, inclusive a Itália, já abandonou essa ideia, tornando o estudo do prejuízo completamente dissociado das classificações dos vícios.

${ }^{570}$ Ainda no tema, Jorge Coutinho Paschoal (O prejuízo na teoria das nulidades processuais penais e sua análise jurisprudencial nos Tribunais Superiores, cit., p. 328), de certa maneira, concorda com o que foi exposto. Para o autor, "cabe deixar claro que somos céticos com relação a essa clássica divisão que se faz, especialmente no que toca ao prejuízo, de que em um tipo de nulidade haveria presunção de prejuízo e, em outro, não.”
} 
reparação. ${ }^{571}$ Ao se rotular o prejuízo conforme a classificação da nulidade, essas peculiaridades não são levadas em conta, permitindo ao juiz se esquivar do exame detido da regra do pas de nullité sans grief apenas com a alegação genérica de que o erro processual se enquadra nessa ou naquela hipótese.

De certa forma, é salutar o pronunciamento do Supremo Tribunal Federal no sentido de que "a demonstração do prejuízo, a teor do art. 563 do CPP, é essencial à alegação de nulidade, seja ela relativa ou absoluta, eis que, o âmbito normativo do dogma fundamental da disciplina das nulidades - pas de nullité sans grief - compreende as nulidades absolutas." ${ }^{572}$ Não há como negar que, independentemente do objeto analisado no julgado, a Corte Suprema parte de uma premissa correta, a de que o prejuízo independe da classificação conferida ao vício. ${ }^{573}$

Repita-se, para não haver confusão: essa concepção, em nada, afeta as garantias do acusado dentro do processo (as quais devem ser fundamentalmente preservadas). $\mathrm{O}$ simples fato de se presumir o prejuízo em casos de nulidade absoluta, por mais que possa parecer, não protege o réu contra eventuais abusos dentro do processo. Os precedentes jurisprudenciais comprovam que as categorias absoluta/relativa não estão lastreadas em conceitos claros e firmes, o que as torna maleáveis e possibilita ao julgador afirmar, em um determinado caso, que o vício não gera uma nulidade absoluta, exigindo da parte a demonstração efetiva do prejuízo.

É por isso que os estudos devem se concentrar mais no papel da forma no âmbito do processo penal, conhecendo, por consequência, o prejuízo de seu não cumprimento, do que propriamente nas hipóteses casuísticas que configuram uma nulidade absoluta ou relativa. Ao se pretender simplificar a categoria do prejuízo, condensando-a em regras padronizadas (ex. quando a nulidade for absoluta, presumido será o prejuízo), acaba-se por deixar de lado justamente aquilo que deveria ser o cerne da questão, qual seja, o verdadeiro significado do prejuízo nas nulidades.

\footnotetext{
${ }^{571}$ Assim é que, sobre a indispensabilidade do prejuízo nas nulidades, lembra Ada Pellegrini Grinover (GRINOVER, Ada Pellegrini. O processo: III Série: estudos e pareceres de processo penal, cit., p. 113) que "deve-se se salientar que, seja o prejuízo evidente ou não, ele deve existir para que a nulidade seja decretada. E nos casos em que ficar evidenciada a inexistência do prejuízo não se cogita de nulidade, mesmo em se tratando de nulidade absoluta."

${ }^{572} \mathrm{HC}$ 85.155/SP, $2^{\mathrm{a}}$ T., rel. Ministra Ellen Gracie, j. 22.3.2005.

${ }^{573}$ A Suprema Corte, após o leading case de 2005, repetiu esse entendimento em diversos outros acórdãos. Cf. HC 112.212/SP, $2^{\mathrm{a}}$ T., rel. Ministro Ricardo Lewandoski, j. 18.9.2012; AP 481 EI-ED/PA, Tribunal Pleno, rel. Ministro Dias Toffoli, j. 20.3.2014.
} 


\subsection{Diretrizes cumulativas para uma decisão racional sobre o prejuízo nas nulidades}

Estabelecidos alguns pressupostos, e afastados os termos e ideias frequentemente associados (equivocadamente) à categoria do prejuízo, cumpre agora sugerir caminhos para uma maior racionalidade na aplicação da matéria. Importante ressaltar que as diretrizes propostas objetivam fornecer padrões mínimos para decisão acerca da ocorrência do prejuízo, de modo a limitar, ao máximo, a discricionariedade do julgador, fixando, por consequência, parâmetros aptos a conferirem legalidade na declaração das nulidades. ${ }^{574}$

\subsubsection{A presunção de lesão às partes pela inobservância do ordenamento processual - a retomada do caráter garantístico da forma}

Para verificação da máxima pas de nullité sans grief, o prejuízo não se resume apenas a uma definição, um conceito hermético, mas, sim, a uma série de requisitos que, cumulativamente, legitimarão a decisão do julgador. O primeiro passo desse caminho é buscar elementos que sugiram, ao menos à primeira vista, um potencial de lesão às partes processuais. São fatores que possibilitam uma presunção de lesão, e que, a depender de outros critérios do processo decisório, poderão ou não levar ao reconhecimento do prejuízo exigido pelo artigo 563 do Código de Processo Penal.

Quais defeitos que, se cometidos, ao menos a priori, podem ser considerados como um indicativo de lesão à parte? O que se pode observar nos dias de hoje é um genuíno caos interpretativo quanto ao ato resultante de prejuízo no processo penal. Em um sistema desprovido de rol taxativo de nulidades, ${ }^{575}$ a abertura ilimitada concedida ao magistrado para dizer, caso a caso, em que circunstâncias a parte pode ser considerada lesada tende a gerar decisões que não garantem uma necessária segurança jurídica.

Com efeito, não havendo critérios claros nesse sentido, há hipóteses concretas em que o julgador, por exemplo, chega a sugerir inexistir uma presunção de lesão inclusive na prisão do acusado. É dizer: ainda que a prisão em flagrante de um indivíduo tenha sido levada a efeito em desacordo com o ordenamento jurídico, há arestos determinando a exigência de demonstração de algum prejuízo concreto decorrente dessa custódia ilegal

\footnotetext{
${ }^{574}$ Em síntese, é delimitar o poder do juiz na apreciação do pas de nullité sans grief o que se pretende no presente capítulo. Procura-se evitar, na esteira de Ferrajoli, o decisionismo processual, o qual pode ser resumido pelo autor italiano como "la falta de anclajes empíricos precisos y La consiguiente subjetividad de los presupuestos de la sanción.” (FERRAJOLI, Luigi. Derecho y razón, cit., p. 43).

${ }^{575}$ De forma contrária, ou seja, no sentido de que o artigo 564, do Código de Processo Penal não é meramente exemplificativo, cf. MOSSIN, Heráclito Antonio. Nulidades no direito processual penal, cit.
} 
para reconhecimento da invalidade, como se a própria prisão, em si, não fosse lesiva o suficiente. $^{576}$

Ora, se o encarceramento cautelar de um cidadão não constitui um prejuízo - ou ao menos um indicador de lesão - fica realmente difícil imaginar o que se entende, à luz do artigo 563, CPP, como prejuízo para declaração da nulidade do ato. É esse o risco que se corre quando há uma completa ausência de parâmetros, ainda que mínimos, para indicar a ocorrência de lesão em virtude do defeito processual. É preciso, por essa razão, estabelecer um ponto de início, a partir do qual o julgador terá elementos para aquilatar e fundamentar eventual inexistência do prejuízo em decorrência do vício processual.

No afã de sanar referida omissão, e na tentativa de conferir ao menos algumas balizas no tema das nulidades, a doutrina tradicionalmente trata a categoria do prejuízo de maneira simplista, sempre a depender de uma classificação anterior do vício. ${ }^{577}$ Segundo esse posicionamento, sendo a hipótese um caso de nulidade absoluta, presumido estará o prejuízo, ao passo que se o defeito configurar nulidade relativa, não há de se falar em presunção de prejuízo, cabendo à parte a demonstração da ocorrência da lesão.

Por esse raciocínio, e empregando a classificação comumente adotada, conclui-se que a categoria do prejuízo estaria umbilicalmente ligada às garantias constitucionais. ${ }^{578} \mathrm{E}$ dizer: se a verificação da nulidade absoluta depende da vulneração de uma regra constitucional sobre processo, e considerando a presunção da existência do prejuízo em face de qualquer nulidade absoluta, há de se entender, por consequência, que o prejuízo dependeria, para ser presumido, de uma inobservância de ditames constitucionais. ${ }^{579}$

Por óbvio que a transgressão de normas constitucionais evidencia, no mais das vezes, prejuízo às partes no âmbito do processo penal. Uma decisão desprovida de motivação, a juntada de depoimento coligido mediante tortura, ou a prisão realizada fora

\footnotetext{
${ }^{576}$ Por todos, cite-se, no TJ-SP, Habeas Corpus 0122011-17.2012.8.26.0000, 14 ${ }^{\text {a }}$ Câmara do Direito Criminal, rel. Des. Marco de Lorenzi, j. 8.11.2012. Do referido julgado, extrai-se o seguinte excerto: "Inicialmente, no que se refere ao pedido de relaxamento da prisão por alegadas nulidades quando da lavratura do auto de prisão em flagrante, observo que a custódia do paciente decorre de outro título, não mais do flagrante, mas de prisão preventiva decretada pela d. Magistrada a quo, deixando assim superado constrangimento ilegal porventura existente em sua prisão em flagrante. (...) Ainda que assim não fosse, não restou demonstrado, in casu, real prejuízo ao paciente e/ou a sua defesa, advindo da nulidade arguida."

${ }^{577}$ Por todos, cf. PACELLI, Eugenio. Curso de processo penal, cit., p. 813.

${ }^{578}$ PIÑERO BERTOT, Maria Inês. La nulidad como "garantia das garantias". In: DIAZ, Carlos Alberto Chiara (Coord.). Las nulidades y los medios de impugnación en el proceso penal. Buenos Aires: Ed. Delta, 2004.

${ }^{579}$ BADARÓ, Gustavo Henrique Righi Ivahy. Processo penal, cit., p. 576. De se salientar também que o Código de Processo Penal Modelo para Ibero-América, em seu artigo 227, caracteriza como "defeito absoluto", os casos em que há "inobservância de direitos e garantias previstos pela lei fundamental e pelos tratados subscritos pelo Estado."
} 
das hipóteses previstas no artigo $5^{\circ}$, LXI, CF, estreme de dúvidas, são casos que sugerem um prejuízo ao acusado. Tais exemplos, é preciso dizer, derivariam de um descumprimento direto da Carta Política.

No entanto, da mesma forma como já se criticou o conceito de nulidade absoluta, impende reconhecer que é impossível delimitar uma categoria do processo (nesse caso, a do prejuízo), ainda que apenas para presumir a sua existência, com base exclusivamente em sua vinculação com princípios ou garantias constitucionais. ${ }^{580}$ Isso porque, o conceito de "vulneração de garantias constitucionais" (ou regras constitucionais) se revela extremamente aberto e impreciso, dando lugar novamente a uma interpretação indevida pelo julgador do caso. ${ }^{581}$

Em tese, há de se convir que toda e qualquer regra de processo penal guarda alguma relação, mesmo que distante, com normas constitucionais. Como desvincular, exemplificando, as regras que exigem a presença do acusado em audiência de garantias da ampla defesa e contraditório, ${ }^{582}$ previstas na Constituição Federal? De certa forma, constatada a violação dessas regras sempre haverá uma vulneração, direta ou indireta, de normas constitucionais. ${ }^{583}$

De maneira semelhante, seria estranho defender que a inversão nas perguntas para oitiva de testemunhas, com inobservância do artigo 212 do Código de Processo Penal, não vergasta frontalmente a acepção material do devido processo legal (substantive due

\footnotetext{
${ }^{580}$ Para se ter uma ideia de como a violação de um princípio pode ser algo genérico e se espraiar por todo um ordenamento, de se transcrever a lição de Celso Antonio Bandeira de Mello (Curso de direito administrativo. 26. ed. São Paulo: Malheiros Ed., 2009. p. 53): “A desatenção ao princípio implica ofensa não apenas a um específico mandamento obrigatório, mas a todo o sistema de comandos. É a mais grave forma de ilegalidade ou inconstitucionalidade, conforme o escalão do princípio violado, porque representa insurgência contra todo o sistema, subversão de seus valores fundamentais, contumélia irremissível a seu arcabouço lógico e corrosão de uma estrutura mestra.”

${ }^{581}$ Sobre o tema, mas com foco na distinção entre nulidade absoluta e relativa, discorre Jorge Paschoal ( $O$ prejuízo na teoria das nulidades processuais penais e sua análise jurisprudencial nos Tribunais Superiores, cit., p. 339-340): "Cabe destacar que o critério da vulneração dos direitos e garantias fundamentais, da atipicidade constitucional, apesar de ser correto, sofre do mesmo inconveniente que o anterior, alicerçado na violação da ordem pública: também ele se mostra impreciso para diferenciar uma nulidade de outra, já que a violação de um valor fundamental sempre será um pressuposto para o reconhecimento de toda e qualquer nulidade."

${ }^{582}$ Pacelli (Curso de processo penal, cit., p. 824) entende que nem todas violações ao contraditório geram prejuízo. Seria o caso, por exemplo, de "um ato praticado ou a prova levada aos autos não ostentar qualquer potencialidade probatória, nem tiver sido, à luz do caso concreto, objeto de mensuração na decisão final." Já se explorou acima crítica a essa posição, sobretudo por que não se pode confundir prejuízo com influência da decisão final do caso.

${ }^{583}$ No capítulo anterior, já se citou e discutiu alguns precedentes que tocam no tema da necessidade de presença do réu em audiência. Consta que o entendimento majoritário é no sentido de que a ausência de intimação do acusado preso para audiência de inquirição de testemunha constitui nulidade relativa, a qual somente será declarada no caso de demonstração efetiva do prejuízo por parte da defesa. Nesse sentido, cf. STF, HC 115.266/ES, 2 ${ }^{\mathrm{a}}$ T., Rel. Ministro Gilmar Mendes, j. 10.9.2013.
} 
process of law), de status constitucional. ${ }^{584}$ Parece também inegável o liame entre esse vício específico e a Constituição Federal. ${ }^{585}$

$\mathrm{Na}$ realidade, repita-se, a integralidade das regras processuais tem sua matriz assentada, ainda que não aparente ictu oculi, nos ditames da Constituição. Por maior o esforço para dissociar um dispositivo do Código de Processo Penal de sua origem, ver-seá, ao final, que este nasce como desdobramento de algum - ou alguns - "princípio maior" insculpido da Carta Maior. ${ }^{586}$

Porém, se, de um lado, parece muito claro que todo erro processual afeta direta ou indiretamente regras constitucionais, de outro, essa ideia geral, um tanto abstrata, tem permitido ao magistrado, paradoxalmente, afirmar em casos de clara gravidade não ter havido uma lesão direta às garantias constitucionais. Explica-se: quando se estabelece um critério aberto, dentro do qual praticamente tudo pode ser enquadrado, fica difícil separar aquilo que de fato é relevante (e.g. vulneração direta de uma garantia constitucional), daquilo que é insignificante (e.g. violação de uma regra processual que, embora lese mediatamente uma norma constitucional, não prejudica as partes), possibilitando ao magistrado discernir, caso a caso, o que ele entende por uma "vulneração da Constituição Federal". ${ }^{587}$ De se concluir, portanto, que é inadequado estabelecer, a título de presunção de lesão, a hipótese de o vício ter afetado garantias constitucionais, uma vez que tal critério, por sua generalidade, não auxilia em uma melhor estruturação teórica do tema.

Outra maneira de buscar interpretar e dar contornos ao conceito do prejuízo é associá-lo à função intrínseca da norma violada. Para essa corrente de pensamento, toda e qualquer regra processual existe para cumprir um objetivo dentro do ordenamento, sendo

\footnotetext{
${ }^{584}$ Antonio Scarance (Processo penal constitucional, cit., p. 52) emprega a expressão "garantia inominada" para se referir ao devido processo legal. Segundo tal autor, "[o devido processo legal] serve para, por meio de construções doutrinárias e jurisprudenciais, se dê assento constitucional a garantias não expressas."

${ }^{585}$ De se notar que, apesar da evidente correlação entre o vício e a cláusula do devido processo legal, o Superior Tribunal de Justiça firmou entendimento sobre o tema, no sentido de que o prejuízo precisa ser demonstrado para declaração do prejuízo. Nesse sentido, cf. HC 169.910/SP, $6^{a}$ T., Rel. Ministro Sebastião Reis Junior, j. 26.2.2013; RESP 1.302.566/RS, 6 ${ }^{\mathrm{a}}$ T., Rel. Ministra Maria Thereza de Assis Moura, j. 27.6.2014. Em sentido contrário, ou seja, que há uma presunção de prejuízo em virtude da inversão da ordem, cf. HC 137.089, 5 $5^{\mathrm{a}}$ T., Rel. Ministra Laurita Vaz, j. 22.6.2010.

${ }^{586}$ Sob essa ótica, Ada Pellegrini Grinover lembra ser essencial "ler as normas processuais à luz da dos princípios e regras constitucionais", de modo a "verificar a adequação das leis à letra e ao espírito da Constituição." (As garantias constitucionais no processo, cit., p. 14-15).

${ }^{587}$ Dando continuidade à argumentação acima exposta, como sustentar, por exemplo, se tomadas por base as classificações tradicionais, que a inobservância da regra da identidade física do juiz (artigo $399, \S 2^{\circ}$ ) não esteja diretamente ligada à garantia do juiz natural? Mas como toda regra nasce, em tese, como desdobramento de um princípio constitucional, dá-se lugar para o magistrado afirmar que o vício de referida regra processual gera nulidade relativa, cabendo à parte a demonstração do prejuízo. Por todos, TJSP, Apelação 0041950-82.2013.8.26.0050, $8^{\text {a }}$ C. Criminal, Rel. Des. Grassi Neto, j. 2.10.2014.
} 
certo que sempre haverá presunção de prejuízo na medida em que essa função normativa for suprimida ou amputada por força do defeito. ${ }^{588}$

Inclusive, em certos ordenamentos, como é o caso da Itália, ainda que não haja expressa menção ao pas de nullité sans grief $^{589}$ entende-se que a necessidade de uma ofensividade concreta constitui corolário direto da regra segundo a qual um ato imperfeito não será declarado nulo se não houver influído na finalidade para o qual foi estabelecido. ${ }^{590}$ A consecução do escopo do ato, nesse caso, se confunde com a própria ideia de ausência de prejuízo.

Embora voltado ao processo civil, o escólio de CALMON DE PASSOS encontra eco na área penal: “Toda atipicidade acarreta um prejuízo, um dano, desde que os fins do processo ou os fins particulares dos atos não sejam atingidos. Por outro lado, alcançar o fim posto ao ato implica em inexistência do prejuízo, visto como o processo não serve a interesses outros que não os da jurisdição.” E acrescenta o autor baiano: “não nos foi possível, por outro lado, encontrar um só exemplo prático, em centenas de decisões examinadas, que nos autorizasse a distinguir prejuízo e inatingibilidade do fim. Sempre que se afirma o prejuízo, o fim do ato deixou de ser atingido",591

Seguindo essa lógica, todo ato processual guardaria uma função sistemática, cabendo ao julgador verificar se, no caso concreto, esse desiderato foi corretamente observado. Tome-se, por exemplo, o ato de citação. A sua função é essencialmente levar ao conhecimento do réu a acusação contra ele ofertada. ${ }^{592}$ De certo modo, a entender como correta a posição acima, qualquer defeito ocorrido durante o procedimento de citação será relevado, desde que o acusado tome conhecimento dos fatos contra ele imputados. Não é de outro modo que vêm entendendo nossas cortes quando, por exemplo, resta claro nos autos que, embora o réu não tenha sido devidamente citado, há ciência dos termos da

\footnotetext{
${ }^{588}$ A posição é antiga. Segundo lição de Inocencio Borges da Rosa (Nulidades no processo, cit., p. 130) "como ao imputado não se pede conta se materialmente ele transgrediu as prescrições da lei, mas, sim, se violou o seu conteúdo, assim, para poder reconhecer a nulidade de um ato é preciso ver se o escopo da lei foi de fato atingido." No processo civil, cf. Bedaque (Efetividade do processo e técnica processual, cit., p. 449) para quem "ausência de prejuízo corresponde à finalidade alcançada."

${ }^{589}$ “' L'esigenza dell'accertamento in concreto di uma lesione del pregiudizio efetivo è sempre stata sentita ma il legislatore, proprio per i motivi sopra enunciati, non l'ha mai tradotta in norma di legge" (LOZZI, Gilberto. Lezioni di procedura penale. 7. ed. Torino: Giappicehlli Editore, 2010. p. 191)

${ }^{590}$ Cf. IASEVOLI, Clelia. La nullità nel sistema processuale, cit., p. 246.

${ }^{591}$ CALMON DE PASSOS, Joaquim. Esboço de uma teoria das nulidades aplicadas às nulidades processuais, cit., p. 132-133.

${ }^{592}$ Cf. GRINOVER, Ada Pellegrini; FERNANDES, Antonio Scarance; GOMES FILHO, Antonio Magalhães. Nulidades no processo penal, 12. ed., cit., p. 99.
} 
acusação por parte do defensor regularmente constituído. ${ }^{593}$ Presume-se, nessas hipóteses, que o acusado foi noticiado do fato por seu defensor, razão pela qual a função do ato de citação foi cumprida.

É preciso observar, contudo, que nem todos os casos traduzem uma situação tão clara relativa à consecução do escopo do ato. Até porque, nas precisas palavras de João Conde Correia, "uma coisa é a existência de um prejuízo concreto para o interesse tutelado pela norma jurídica violada - que, nalguns sistemas, consubstancia de facto uma nulidade mesmo na ausência de previsão legal - e outra muito diferente, em termos formais e substanciais, é a realização da finalidade prosseguida, que apenas vem remediar a infracção cometida."

Retome-se, apenas para fins de facilitação do argumento, a hipótese de citação do acusado. Para tanto, de se remeter a um exemplo de possível vício que ocorria antes da alteração de 2008 do Código de Processo Penal, época em que o interrogatório do réu era o primeiro ato do processo. E se o acusado, ainda sob a vigência do procedimento antigo, fosse citado regularmente em sua residência, mas apenas um dia antes da audiência de interrogatório? A verdade é que, teoricamente, a função primordial da citação foi cumprida, já que os termos da acusação foram comunicados ao réu. E mais: não há qualquer dispositivo legal que imponha expressamente ao Estado que realize essa citação com uma antecedência mínima. ${ }^{595}$ Porém, em um Estado de Direito que se preze, parece indispensável que o acusado seja citado a tempo de poder exercer uma defesa compatível com os ditames da Constituição, sendo razoável supor que a comunicação levada a efeito com apenas um dia de antecedência deverá ser considerada nula. ${ }^{596}$ Fosse apenas o caso analisado sob a ótica da função intrínseca da norma, inexistiria prejuízo.

\footnotetext{
${ }^{593}$ No STF: HC 121.374/RS, $2^{\mathrm{a}}$ T., Rel. Min. Ricardo Lewandowski, j. 6.5.2014; RHC 87.699, $2^{\mathrm{a}}$ T., Rel. Min. Cezar Peluso, j. 2.6.2009. No STJ: HC 259.760/SC, 6 ${ }^{a}$ T., Rel. Min. Maria Thereza de Assis Moura, j. 27.5.2014; RHC 39.105, 6 T T., Rel. Min. Rogerio Schietti Cruz, j. 13.5.2014.

${ }^{594}$ CONDE CORREIA, João. Contributo para análise da inexistência e das nulidades processuais penais, cit., p. 181.

${ }^{595}$ De se esclarecer, por oportuno, que a Convenção Americana de Direitos Humanos, internalizada em nosso ordenamento pelo Decreto 678/92 prevê que "durante o processo, toda pessoa tem direito, em plena igualdade à comunicação prévia e pormenorizada da acusação formulada." (art. 8, 2, b) No entanto, a palavra "prévia", por sua vagueza, não garante ao acusado uma antecedência mínima de dias ou horas para ser citado.

${ }^{596}$ Essa questão foi intensamente debatida perante o STF, vencendo a posição que reconhecia a nulidade do ato. HC 109.611/RS, $1^{\mathrm{a}}$ T., Rel. Min. Marco Aurélio, j. 4.6.2013.À época do mencionado precedente, o interrogatório constituía o primeiro ato da instrução, sendo certo que se discutia se a citação poderia ocorrer com apenas um dia de antecedência. Vale reproduzir, sobre o tema, as palavras do Ministro Marco Aurélio: "Todo e qualquer acusado deve contar com a possibilidade de constituir advogado e com este, antes do comparecimento ao Juízo, manter o indispensável contato. Isso não ocorre quando não há, entre a data da citação e a da audiência, tempo suficiente a fazê-lo, como é o restrito a um único dia." Em sentido contrário, no STJ: HC 142.994/SP, 5 ${ }^{\text {a }}$ T., Rel. Ministro Gurgel de Faria, j. 16.9.2014.
} 
Não se discorda, logicamente, de que todo ato tem uma função. A forma, na seara penal, guarda ainda maior relevância justamente por ser a responsável por permitir a permeabilidade das garantias do acusado dentro do processo. A observância da forma, segundo BINDER, não é de nenhuma maneira um fim, mas, sim, o meio para assegurar princípios maiores. ${ }^{597}$ Temerário, desta forma, descartar a importância exercida pelos atos processuais dentro do ordenamento jurídico.

Por outro lado, embora não se deva minimizar a importância da função intrínseca de cada ato, isso não autoriza, em absoluto, uma conclusão automática de que o prejuízo com ela se confunde. Para se compreender tal raciocínio, há de se recorrer novamente à casuística. Qual seria a função do artigo 600, do Código de Processo Penal, ao prever um prazo de oito dias para apresentação de contrarrazões de apelação? Certamente, o legislador, ponderando princípios e regras, chegou à conclusão de que o prazo assinalado na norma seria suficiente para, de um lado, garantir ao apenado tempo para elaboração de uma peça argumentativa, e, de outro, conferir a necessária celeridade ao processo. ${ }^{598}$ Dito isso, verifica-se que eventuais contrarrazões apresentadas de forma extemporânea, por exemplo, no décimo dia, lesariam, ao menos em tese, a ratio da norma disposta no aludido dispositivo legal. Porém, só por isso, já haveria uma presunção de prejuízo em favor do apelante? Parece que a resposta a tal indagação deva ser negativa.

Com efeito, há de se entender que as contrarrazões apresentadas a destempo pela defesa (apelada), se não houver influírem no correto andamento do feito, e se não forem deliberadamente apresentadas fora do prazo para beneficiar o réu (ex. para aguardar o transcurso de prazo prescricional), não geram qualquer prejuízo às partes. É assim que têm entendido os Tribunais, o mesmo ocorrendo em relação às contrarrazões de apelação intempestivas apresentadas pelo Ministério Público. ${ }^{599}$

Forçoso, portanto, compreender que, embora muito relevante em alguns sentidos, é certo que o critério de vulneração da função intrínseca da norma não se mostra como o mais adequado para estabelecer os contornos suficientes do prejuízo no tema das

\footnotetext{
${ }^{597}$ BINDER, Alberto. El incumplimiento de las formas procesales, cit., p. 72.

${ }^{598}$ Tourinho Filho (Processo penal, cit., v. 3, p. 110) ensina que os prazos são regidos por dois princípios: o da igualdade de tratamento e o da brevidade. De acordo com esse segundo princípio, os prazos processuais não podem ser muito dilatados, já que, fosse o contrário, o processo arrastar-se-ia durante um espaço de tempo insuportável para as partes.

${ }^{599}$ No STJ: AgRg no HC 229.104/SP, 6a T., Rel. Min. Sebastião Reis Júnior, j. 5.9.2013. TJ-SC, Apel. 73.131, $1^{\text {a }}$ C., Rel. Des. Claudio Valdyr Helfenstein, j. 20.4.2009. Faça-se aqui uma importante observação: a intempestividade das contrarrazões apresentadas pelo Ministério Público pode, em determinados casos, configurar um prejuízo ao réu. Um exemplo claro ocorre quando o acusado está preso.
} 
nulidades. $\mathrm{O}$ fato de ter sido a ratio normativa açoitada não significa, necessariamente, a ocorrência do prejuízo exigido pelo artigo 563 do CPP.

Em face dessas observações, verifica-se a complexidade em encontrar uma definição apta a, por si, englobar o significado do prejuízo. Prefere-se, aqui, trabalhar com uma noção de presunção de lesão, a qual, submetida a outros requisitos, poderá ou não levar o julgador a reconhecer a ocorrência do prejuízo às partes. É, consoante já referido, o primeiro critério analítico para se formar uma decisão racional para aplicação do pas de nullité sans grief.

No intuito de encontrar parâmetros condicionantes para se presumir que o vício lesou as partes, torna-se necessário resgatar algumas ideias externadas no primeiro capítulo do presente trabalho. Essencial, dessa forma, lançar luzes novamente sobre o papel da forma no âmbito específico do processo penal, de modo a entender as hipóteses em que a inobservância do ordenamento se torna relevante.

Frise-se que a forma do ato processual, determinada pelo legislador, tem uma razão de existir. ${ }^{600}$ Há de se entender, conforme já se disse, e fazendo uma análise histórica de sua existência, que a forma, notadamente no processo penal, representa a limitação da atuação do Estado, sem a qual jurisdicionados ficariam à mercê dos mandos e desmandos do poder. ${ }^{601} \mathrm{Se}$, de um lado, é verdade que o excesso de formalismo promove uma indesejada burocratização do processo, de outro, não se pode esquecer que a forma, em si, possui um conteúdo garantístico inafastável. ${ }^{602}$

Em última instância, a rigorosa observância da forma, para muito além de ser um dever para com os sujeitos processuais, é o que garante, em tese, um processo devido, previsível e respeitador das mais variadas garantias constitucionais. E se assim é, parece também correto afirmar que o desrespeito à forma processual, por menor que seja, consubstancia ao menos uma presunção de lesão às partes. Sustentar o contrário, ou seja, defender de maneira abstrata, mesmo diante do descumprimento do ordenamento processual, a inexistência de qualquer lesão presumida em determinados casos, significaria

\footnotetext{
${ }^{600}$ De novo, vem a mente a lição de Binder (El incumplimiento de las formas procesales, cit., p. 43) segundo a qual deve estar claro o que está sendo protegido pela forma. Caso contrário, ela estará apenas protegendo a rotina, os ritos e o ritmo da burocracia judicial.

${ }^{601}$ Carlos Alberto de Oliveira explica que, sob um panorama mais abrangente, a questão do formalismo processual está ligada à perspectiva do poder estatal. (Do formalismo no processo civil, cit., p. 85).

${ }^{602}$ Cf. PASSO CABRAL, Antonio do. Nulidades no processo moderno: contraditório, proteção da confiança e validade prima facie dos atos processuais, cit., p. 90 .
} 
admitir que algumas fórmulas são inúteis dentro do processo penal, o que se revela inconsistente com o exposto até aqui.

Note-se que não se está negando o importante avanço trazido pelo movimento instrumentalista no sentido de emprestar sentido finalístico, e não apenas literal, aos atos processuais. De fato, a ideia da forma como sendo um fim em si mesmo não tem mais espaço nos dias atuais. No entanto, é imprescindível criar critérios justamente para que o apontado aspecto instrumental do processo não se torne, tal como ocorre hodiernamente, carta branca para flexibilização desenfreada das formas.

Com efeito, se a pretensão é estruturar uma melhor sistematização do tema relativo ao prejuízo nas nulidades, cumpre desenvolver uma hipótese inicial a qual, se verificada no caso concreto, apontará para um mínimo grau de dano, aqui denominado de presunção de lesão. Trata-se de uma presunção relativa, iuris tantum, que pode ser afastada com base em outros requisitos de análise adiante destacados.

Essa hipótese inicial, ou melhor, essa presunção de lesão, é definida como toda e qualquer violação da forma processual, seja ela estabelecida explicitamente pelas normas de processo penal, ou esteja ela compreendida implicitamente em princípios e garantias constitucionais. Em síntese, é o descumprimento do ordenamento processual que resulta na presunção de lesão às partes.

O Código de Processo Penal chileno prefere definir, já em seu corpo, o termo prejuízo, que ocorreria toda vez que a inobservância das formas processuais atentasse contra as possibilidades de atuação de qualquer dos intervenientes do processo. ${ }^{603} \mathrm{~A}$ despeito de se tratar de diploma legal moderno, tal conceituação parece insuficiente para sequer definir a presunção de lesão pretendida no presente capítulo. Isso porque, a ideia do prejuízo não pode estar vinculada apenas e tão somente à atuação dos sujeitos no âmbito do processo penal. Há nulidades que não necessariamente estão ligadas à atuação da parte, como é o caso do uso abusivo de algemas (súmula vinculante $n^{\circ} 11, \mathrm{STF}$ ), ou da decisão que impõe a manutenção da prisão cautelar desprovida de necessidade (art. 312, CPP). Portanto, as hipóteses de presunção de lesão devem ser ainda mais abrangentes quando comparadas com a definição de prejuízo contida no CPP do Chile.

Convém esclarecer a razão pela qual não apenas a inobservância de regras explícitas de processo penal gerará a presunção, mas também a inobservância de princípios

\footnotetext{
${ }^{603}$ Art. 159, Código de Processo Penal Chileno.
} 
e garantias implícitas no processo. É que, na realidade, existem hipóteses em que não se extrai de uma norma específica a forma pela qual o ato deve ser praticado, sendo ela decifrável a partir da leitura sistemática de todo o ordenamento.

À casuística: o Brasil e os Estados Unidos da América celebraram um acordo bilateral MLAT, internalizado em nosso ordenamento pelo Decreto 3.810/01, por meio do qual ambos os países se comprometem a cooperar na apuração de delitos. Ocorre que sempre que a defesa, num processo criminal tramitando em nosso país, requer a produção de provas nos EUA, esse pedido é negado, sob o fundamento de que aquele país estrangeiro somente cumpre diligências a pedido do próprio juiz ou da acusação. Sem adentrar na discussão de soberania, fica difícil negar que impedir a defesa de produzir provas em outro país, enquanto se confere à acusação livre e irrestrito acesso a diligências probatórias, vergasta frontalmente as garantias constitucionais do contraditório e da paridade de armas. Assim, ainda que inexista uma regra sobre esse tema específico no referido acordo de cooperação internacional, é preciso convir que, nesses casos, é facilmente perceptível a presunção de lesão ao acusado. ${ }^{604}$

Outra questão, apta a ilustrar o aqui exposto, está ligada ao direito de presença, física ou remota, do acusado nas audiências de oitiva das testemunhas. De novo, a despeito de inexistir dispositivo legal expresso nesse sentido, parece claro que quando a Constituição Federal insculpe, em seu artigo $5^{\circ}$, a garantia da ampla defesa, pretende também assegurar ao réu o direito de comparecer às audiências durante a instrução criminal. Destarte, também nesse caso, a decisão que nega ao acusado esse direito também é suficiente para gerar, no mínimo, presunção de lesão, que eventualmente poderá resultar em prejuízo. ${ }^{605}$

Em relação à definição de presunção de lesão aqui defendida, certamente haverá crítica no sentido de ser ela extremamente genérica. Ou seja, poder-se-ia afirmar, em tom de censura, que praticamente todo tipo de violação de regras processuais, mesmo as mais insignificantes, se amoldariam ao conceito de lesão presumida. A sustentar tal posição, cite-se, como exemplo de uma imperfeição ínfima, o fato de um membro do conselho de sentença não ficar em pé no momento da exortação prevista no artigo 472, do Código de

\footnotetext{
${ }^{604}$ Nesse sentido, reconhecendo inclusive a nulidade da decisão que nega o pedido de provas com base no MLAT, o STJ já se pronunciou sobre a matéria: HC 208.663/SP, 5 ${ }^{\mathrm{a}}$ T., Rel. Min. Jorge Mussi, j. 2.10.14.

${ }^{605}$ Sobre essa questão específica, e o tratamento dado pela jurisprudência, cf. item 3.4.1 supra.
} 
Processo Penal. Como tal vício, insignificante de fato, poderia caracterizar uma presunção de lesão às partes?

Assevere-se, em resposta a eventual crítica, que a presunção de lesão não significa necessariamente a existência de um prejuízo; configura, apenas e tão-somente, o primeiro passo para uma decisão racional. Provavelmente, muitas imperfeições jamais evidenciarão um prejuízo efetivo, à luz do artigo 563 do CPP, porém caracterizarão lesões presumidas, as quais necessariamente deverão ser analisadas pelo magistrado. Trata-se de uma posição de respeito (que não se confunde com formalismo) para com a forma processual. É dizer, se os termos da lei não são inócuos, não se pode tratar a sua inobservância com indiferença.

\subsection{2. Ônus argumentativo para afastamento da presunção de lesão}

Possivelmente o ponto de maior importância na estruturação de um processo racional para aferição do prejuízo seja a correta atribuição do ônus argumentativo para verificação da existência ou não de lesão às partes. A quem caberia, afinal, demonstrar que o vício processual gera algum tipo de prejuízo à defesa ou à acusação? ${ }^{606}$

Tradicionalmente a doutrina, ${ }^{607}$ encampada à unanimidade pela jurisprudência pátria, ${ }^{608}$ tem entendido ser obrigação da parte que suscita a nulidade demonstrar a ocorrência do prejuízo. A despeito da categorização que se fazia antigamente em nulidade absoluta (prejuízo presumido) e nulidade relativa (sem presunção de prejuízo), é certo que o posicionamento mais atual é no sentido de que o prejuízo deve ser comprovado “independentemente da sanção prevista para o ato, podendo ser ela tanto de nulidade absoluta, quanto relativa, pois não se declara nulidade por presunção."609

\footnotetext{
${ }^{606}$ A questão se faz necessária porque, segundo Ada Pellegrini Grinover, o dano deve ser concreto e efetivamente demonstrado em cada situação. (O processo: III Série: estudos e pareceres de processo penal, cit., p. 113).

${ }^{607}$ Cf. PACELLI, Eugenio. Curso de processo penal, cit.; NUCCI, Guilherme de Souza. Código de Processo Penal comentado. 8. ed., cit.; TOURINHO FILHO, Fernando da Costa. Processo penal, cit., v. 3.

${ }^{608}$ Nesse sentido, por todos, no STF, HC 110.936/RS, $2^{\mathrm{a}}$ T., Rel. Min. Carmen Lucia, j. 25.9.2012. No STJ, RHC 46.792/MG, 5 ${ }^{\mathrm{a}}$ T., Rel. Min. Laurita Vaz, j. 26.8.2014; HC 259.657/PR, $6^{\mathrm{a}}$ T., Rel. Min. Rogerio Schietti Cruz, j. 21.8.2014. No TJSP, Apel. Crim. 0030721-33.2012.8.26.0577, 9a C., Rel. Des. Laerte Marrone, j. 9.10.2014; Apel. Crim. 90000-46.2010.8.26.0224, 8 a C., Rel. Des. Lauro Mens de Mello, j. 4.9.2014.

${ }^{609}$ STF, HC 121.350/DF, $1^{\text {a }}$ T., Rel. Min. Luiz Fux, 13.5.2014. Oportuno salientar que no referido precedente há citações de inúmeros outros julgados nos quais se exige a demonstração do prejuízo, independentemente de ser a nulidade relativa ou absoluta.
} 
Dessa forma, se a defesa sente-se prejudicada em virtude de o ato processual não ter sido levado a efeito de maneira correta, cabe a ela colher elementos suficientes de modo a comprovar que não se trata de mera irregularidade. Segundo esse entendimento, portanto, a carga probatória recairia sobre a parte supostamente lesada, sendo certo que a ausência ou impossibilidade de comprovação efetiva do prejuízo geraria o reconhecimento da eficácia do ato.

Todavia, não parece ser esse o entendimento mais correto. Aliás, diga-se que grande parte das incoerências e injustiças impostas pelo atual modelo de nulidades exsurge justamente dessa visão míope de imposição do ônus argumentativo àquele que identifica um defeito no decorrer do processo penal. ${ }^{610}$ De modo irrefletido, aplica-se ao tema das nulidades a mesma lógica que ocorre com a teoria das provas, ou seja, a prova da alegação incumbe a quem a fizer (art. 156, CPP). ${ }^{611}$ Essa concepção, para além de equivocada, cerra os olhos para pilares basilares do processo penal.

Por maior a obviedade, é preciso lembrar que as partes não optam pela forma como irá transcorrer o processo; este, muito ao revés, encontra seus contornos e limitações (enfim, sua legitimidade) em normas criadas pelo Estado, inexistindo espaços discricionários privativos. Um agente acusado de homicídio será processado com base em um procedimento pré-estabelecido pelo ordenamento vigente, com o mesmo rigor e as mesmas benesses que qualquer outro agente em condição análoga. Tanto o órgão acusador quanto a defesa não têm, por assim dizer, liberdade para escolher a forma que lhes convém para praticar um ato processual. Daí porque já se pode afirmar que o cumprimento rigoroso das "regras do jogo" não é favor prestado aos sujeitos processuais, mas, antes e sobretudo, uma imposição do Estado a eles. ${ }^{612}$

\footnotetext{
${ }^{610}$ Sobre as mazelas atuais de nosso sistema de nulidade, Alexandre de Morais Rosa (Guia compacto do processo penal conforme a teoria dos jogos. 2. ed. Rio de Janeiro: Lumen Juris, 2014. p. 196) preceitua que "no Brasil, a teoria das nulidades do processo penal, com origem civilista, é caótica. Prevalece a discussão entre ausência do prejuízo, malversação das normas procedimentais, enfim, dilemas ideológicos travestidos de questões procedimentais, cuja superação é necessária."

${ }^{611}$ Art. 156, caput, CPP: "A prova da alegação incumbirá a quem a fizer, sendo, porém facultado ao juiz de ofício (...)." Apesar de não ser objeto de estudo no presente trabalho, vale ressaltar que o dispositivo legal em questão deve ser interpretado com ressalvas diante da nova realidade constitucional pós-88. Nesse sentido, Carlos Fonseca Monnerat (Inversão do ônus da prova no processo penal brasileiro. São Paulo: Communicar, 2006. p. 106) afirma que a regra contida no artigo 156, CPP é, "por si, dúbia e de interpretação equívoca (...) Há de se buscar no sistema processual penal sua complementação. Essa complementação é encontrada na Constituição Federal Brasileira, na garantia do in dubio pro reo."

${ }^{612}$ Capone chega a mencionar que a correta observação da forma processual é um ônus normativo. "É próprio in questo senso, d'altre parte, che l'adempimento de tali formalità può essere considerato un onere: perchè la norma processuale nel medesimo momento in cui consente a um soggeto di perseguire determinate finalità vieta che esse possano essere raggiunte se non nel modo che essa stessa prescreve." (L'invalidità nel processo penale, cit., p. 254).
} 
Seguindo esse raciocínio, ao se apontar um vício no decorrer da persecução penal, necessário compreendê-lo como uma possível ruptura do caminho ideal e pré-fixado pelo próprio Estado para apuração daquele fato específico sob julgamento, e não como um interesse da parte para que seja, à sua maneira, promovida a justiça. O eventual reconhecimento da nulidade, em última instância, é a correção de rumo de um ato praticado em desconformidade com a determinação estatal.

Como, então, diante dessa esteira de pensamento, admitir que às partes seja atribuído o ônus de demonstrar o prejuízo decorrente do vício? Ou seja, o Estado cria as leis; o Estado processa o cidadão; o Estado comete um erro na aplicação dessas leis durante o processo; e é o cidadão que deve comprovar o prejuízo? Não faz, de fato, nenhum sentido. Trata-se de um ônus despropositado e irracional que apenas encontra campo fértil em um modelo de processo penal inquisitório, em que as formas se amoldam - tudo a depender do caso - ao alvedrio do magistrado, sendo o acusado mero objeto desprovido de direitos.

Não bastasse isso, é comum ouvir que a parte não só tem o ônus de argumentar, mas precisa provar um efetivo prejuízo em decorrência do vício. No entanto, não há qualquer discussão a respeito de como essa prova poderia ser feita, ou mesmo qual seria o standard probatório exigido para caracterização do prejuízo. ${ }^{613}$ É verdade que essa discussão específica deixaria ainda mais evidente o desatino de exigir da parte a demonstração do prejuízo, tendo em vista que em muitos casos é impossível comprovar um dano concreto à parte. Aliás, como demonstrar, por exemplo, um prejuízo efetivo de um ato produzido em desarmonia com o ordenamento, se é impossível saber o que teria acontecido se tivesse sido praticado de forma regular (ex. oitiva de testemunha de acusação sem a presença do acusado)?

Em um modelo racional de aferição do prejuízo, qualquer ônus deve necessariamente recair sobre a pessoa investida pelo Estado do poder para fiscalizar a regular tramitação do processo, que é o juiz. Como se viu supra, existe uma presunção de lesão às partes pelo simples descumprimento do ordenamento processual. Ao magistrado

\footnotetext{
${ }^{613} \mathrm{~A}$ importância de discutir mais a fundo o grau probatório do prejuízo ganhou corpo também nos Estados Unidos da América. Em relação ao "harmless error", explica William Wesley Patton (To err is human, to forgive, often unjust, cit., p. 108): "Discussions of standards of review are often difficult to follow because courts and scholars frequently do not make explicit which of the four basic components of a standard review is being considered. The standard of review must allocate the degree of proof necessary for judicial relief and determine which party must carry the burden of persuasion."
} 
cabe, uma vez verificado o vício processual, expor fundamentos para sustentar se essa inicial presunção de lesão deve ou não ser afastada no caso concreto.

Com extrema precisão, BADARÓ ${ }^{614}$ leciona que incumbe ao juiz, e não às partes, externar os motivos pelos quais a atipicidade não gerou prejuízo às partes. No processo penal, ao se cuidar de nulidades, sustenta o autor, deve haver uma inversão de sinais, por meio da qual se entende que em princípio o ato atípico gera uma consequência relevante e, em tese, prejudicial, visto que as formas representam garantias do acusado. ${ }^{615}$

Ressalte-se que no âmbito do processo penal a atipicidade gera uma lesão prima facie, a qual somente pode ser invertida pelo julgador em casos excepcionais. É preciso pensar a questão sob um enfoque diferente do atual, de maneira a entender que há uma prioridade constitucional e apriorística pela danosidade do ato viciado. ${ }^{616}$ Tal presunção milita em favor das partes (especialmente do acusado), cabendo ao juiz encontrar fundamentos suficientes, em cada caso concreto, para alterar o sinal inicialmente apontado para a lesão.

De se notar que não se exige, do juiz, necessariamente a produção de provas efetivas aptas a lastrearem a ocorrência ou não de lesão em virtude do ato defeituoso. De fato, se essa exigência se revela impossível na maioria dos casos para as partes, consoante já se criticou, seria impróprio impor essa mesma obrigação ao julgador. Em verdade, o ônus é meramente argumentativo, por meio do qual, em uma operação lógica e racional, deverão ser consignadas razões para acreditar não ter o defeito causado a lesão presumida desde o início.

Aludida fundamentação, que inibe a instalação de um sistema hermético e perfeito, assegurará maior controlabilidade da decisão de aferição das nulidades. Para além de retirar da parte o (indevido) encargo de demonstrar um efetivo prejuízo, uma exaustiva motivação conferirá legitimidade maior ao decisum judicial, permitindo, inclusive, que magistrados de instâncias superiores possam ter maior substrato para definir se os fundamentos ali lançados estão em sintonia com a norma vigente. ${ }^{617}$

\footnotetext{
${ }^{614}$ BADARÓ, Gustavo Henrique Righi Ivahy. Processo penal, cit., p. 578.

${ }^{615}$ A propósito, Aury Lopes Junior (Sistema de nulidades 'a la carte' precisa ser superado no processo penal, cit.) também utiliza a expressão "inversão dos sinais" no tocante ao assunto. Segundo o autor "Querem salvar a categoria do prejuízo? Difícil, senão até, desnecessário. Mas a Teoria da Inversão dos Sinais pode ajudar. Não é a parte que alega a nulidade que deverá demonstrar o prejuízo que o ato atípico lhe causou (...) senão que incumbe ao juiz, para manter a eficácia do ato, que deverá justificar por quais razões a atipicidade não impediu que o ato atingisse sua finalidade."

${ }^{616}$ De forma contrária, Antonio do Passo Cabral (Nulidades no processo moderno: contraditório, proteção da confiança e validade prima facie dos atos processuais, cit., p. 190) preceitua que é necessário pensar em um "princípio da validez dos atos processuais" como prioridade normativa.

${ }^{617}$ Afinal, como bem explica Perfecto Ibañez, "não basta ao juiz afirmar ter (para si) uma convicção, deve expô-la para compartilhá-la (...) pode ser visto com clareza no caso do voto dissidente em um tribunal
} 
Essa fundamentação, no entanto, não pode ser feita com base no grau de afetação do vício no deslinde final da causa. Frise-se: o prejuízo de um ato imperfeito não está somente vinculado a um critério finalístico, em que o meio empregado deixa de ser importante para consecução de um resultado prático. A sustentar o contrário, bastaria o magistrado justificar a ausência de lesão do vício com base na indiferença daquele ato específico para o seu convencimento da matéria objeto de julgamento. Nesse caso, o elevado contingente subjetivo, aliado à desimportância conferida à natureza do ato processual penal em si, tornariam essa fundamentação inócua.

Ao declinar as razões para eventualmente inverter a inicial presunção de lesão do vício, o julgador deve levar em conta a particular importância que a forma assume no processo penal. ${ }^{618}$ Torna-se obrigatório, desta feita, sustentar o motivo pelo qual o erro levado a efeito no curso da persecução penal, naquele caso específico, não suprimiu nem diminuiu, de nenhuma maneira, o direito ou a garantia conferida pela norma à parte.

É verdade que existem hipóteses raras e específicas - as quais serão mencionadas adiante no trabalho - em que a própria forma de atuar da parte exonerará o juiz de elaborar um fundamento mais aprofundado sobre a existência da lesão (p. ex. quando a própria parte tiver causado o vício). Porém, como regra, cumpre repetir, recai sobre o magistrado o ônus argumentativo de expor os motivos pelos quais a inobservância da forma não impediu a atuação legítima da acusação ou defesa, restando, por isso, afastada a presunção de lesão prima facie. ${ }^{619}$

colegiado, que muito bem pode partir dos mesmos dados probatórios utilizados na resolução da maioria, mas, isto sim, entendidos de uma maneira diversa. Modo de entender discrepante que nunca poderia projetar-se para fora do órgão como um simples porque sim." (IBAÑEZ, Perfecto. Sobre a motivação dos fatos na sentença penal. In: ANDRADE, Lédio Rosa de (Org.). Valoração da prova e sentença penal. Trad. Lédio Rosa de Andrade. Rio de Janeiro: Lumen Juris, 2006. p. 109-110).

${ }^{618}$ Sobre o tratamento diferente que deve ser conferido aos casos de processo penal, quando comparado ao processo civil, já se debruçou a Corte do $9^{\circ}$ Circuito de Apelação norte-americana. De acordo com o precedente, as regras de persuasão a respeito do dano causado às partes em decorrência do ato imperfeito devem ser mais brandas no caso do processo penal: "Accordingly, a crucial first step in determining how we should gauge the probability that na error was harmless is recognizing the distinction between civil and criminal trials (...) First, the lower burden of proof in civil cases implies a larger margin of error (...). The second facet of distinction between errors in civil and criminal trials involves the differing degrees of certainty owed to civil and criminal litigants. Whereas a criminal defendant must be found guilty beyond a reasonable doubt, a civil litigant merely has a right to a jury verdict that more probably than not corresponds to the truth." (Haddad v. Lockheed California Corp., 720 F2d 1454 ( $9^{\text {th }}$ Cir. 1983).

${ }^{619}$ A despeito da notória diferença no modelo de processo, relevantes as ponderações de Carolyn Jourdan, que, ao analisar a questão do "harmless error", asseverou: "The burden is on the state to rebut the Tennessee common-law presumption of prejudice resulting from any jury separation that occurs without defendant's consent, and in the absence of a sufficient explanation a new trial must be granted. Although the harmless error may be relevant after the state has rebutted the common-law presumption, the statute cannot be invoked to shift the burden of proving prejudice to defendants." (JOURDAN, Carolyn. Criminal law and procedure - jury separation - burden of proof of prejudice to defendant. Tennessee Law Review, v. 48 , p. 148,1980$)$. 


\subsubsection{A "perda de uma oportunidade processual" como critério indicador de lesão}

Na questão de aferição do prejuízo relacionada às nulidades, já definido que o ônus argumentativo recai sobre o julgador, há ainda uma complexa barreira a ser necessariamente sobreposta, cuja discussão ainda se encontra em estágio incipiente na doutrina pátria. Ocorre que, no mais das vezes, o ato produzido de forma viciada cria óbice para saber, ao certo, se o resultado poderia ser diverso caso ele fosse realizado conforme a lei.

Com efeito, em uma operação racional para aferir o grau de lesão gerado pelo vício processual, raros são os casos em que é possível medir com precisão o verdadeiro "estrago" feito pelo ato. Em regra, o defeito impõe alguma forma de impedimento na atuação das partes, sendo certo que ao juiz fica praticamente inacessível o conhecimento do conteúdo do ato perfeito. Até porque, nas palavras de BocCHIOLA, "aquilo que não aconteceu não pode nunca ser objeto de certeza absoluta." 620

Trata-se, portanto, de uma operação virtual, por meio da qual o operador do direito pode apenas imaginar os possíveis desdobramentos do ato se tivesse sido regularmente produzido, verificando, em um segundo momento, a extensão do dano em decorrência do vício. $^{621}$ Não é difícil perceber que essa abstração absoluta em relação à realidade pode causar inúmeras distorções, bem como permite a influência de um subjetivismo desmedido em um tema tão sensível quanto o das nulidades.

De modo a compreender as consequências pragmáticas da matéria, de se recorrer novamente à casuística. Considere-se uma vez mais a questão, já debatida à exaustão no presente trabalho, da falta de requisição do acusado preso para a audiência de oitiva das testemunhas de acusação. Evidencia-se, nesse caso, uma presunção de lesão, na medida em que houve um claro desrespeito à garantia da ampla defesa (especificamente, na modalidade pessoal), de status constitucional. Porém, para se atestar a real extensão da lesão, seria indispensável saber o que o acusado acrescentaria à prova produzida, se presente estivesse na ocasião do depoimento. E isso, convenha-se, não é possível de conhecer, justamente porque ele não esteve naquele ato processual. Essa operação mental

\footnotetext{
${ }^{620}$ BOCCHIOLA, Maurizio. Perdita di una "chance" e certezza del dano. Rivista Trimestrale di Diritto $e$ Procedura Civile, Milano, ano 30, p. 60, 1976.

${ }^{621}$ No tocante ao problema suscitado, Ricardo Gloeckner (Nulidades no processo penal: introdução principiológica à teoria do ato processual irregular, cit., p. 238) indaga: “Como é possível provar-se a vantagem de um ato ainda não praticado? Como é possível a avaliação de um ato processual virtual?” E, por fim, conclui o autor: "Como se pode perceber, o tratamento jurídico das nulidades é algo extremamente caótico na doutrina."
} 
será apenas aproximada, virtual, e não real. ${ }^{622} \mathrm{E}$ nem se pode dizer, como fazem muitos, que seria possível uma análise a posteriori sobre a relevância da presença do acusado, como base na elaboração de questões que poderiam ter sido formuladas durante a audiência. A uma porque não cabe à parte comprovar a incidência do prejuízo, mas, sim, ao juiz expor as razões para afastar, se o caso, a presunção inicial de lesão. A duas porque não se pode impor ao acusado o ônus de ter de antecipar eventuais perguntas que poderiam ser feitas diretamente à testemunha se o ato fosse realizado em conformidade com o ordenamento vigente.

Outro exemplo ilustrativo: a defesa do acusado não comparece à audiência de oitiva de testemunha de acusação realizada fora da comarca de origem, tendo em vista que não fora devidamente intimada da expedição de carta precatória. Segundo o enunciado da Súmula 155, do Supremo Tribunal Federal, trata-se de hipótese de nulidade relativa. Surge, então, a indagação: como saber o que teria ocorrido se o defensor do acusado tivesse sido intimado da expedição da missiva? O que poderia ter mudado no depoimento da testemunha, e como as respostas a eventuais perguntas formuladas pela defesa teriam alterado a prova produzida? Tais questões não possuem uma resposta peremptória e imune a ilações, restando nítido o despautério de exigir da parte, assim como têm determinado as cortes brasileiras, a demonstração do prejuízo real e concreto resultante do vício. ${ }^{623}$

A matéria não é trivial, mas deve ser enfrentada sob o viés da possibilidade perdida em virtude da imperfeição do ato processual. Para tanto, parece essencial recorrer, ao menos em um primeiro momento, aos estudos da responsabilidade civil pela perda de uma chance, a qual poderá potencialmente auxiliar na compreensão de como o magistrado deve proceder na aferição de um prejuízo virtual. ${ }^{624}$ Ainda que, ao final, conclua-se pela inteira inaplicabilidade, no processo penal, da teoria desenvolvida no campo privado, um estudo

\footnotetext{
${ }^{622}$ Vem a calhar a seguinte observação, a qual, apesar de se referir a um dano civil, se encaixa perfeitamente no caso presente: "Nestes casos, os Tribunais costumavam exigir que a vítima produzisse uma prova verdadeiramente diabólica. Isto porque, para o provimento do pedido indenizatório, exigia-se que a vítima provasse que, se o recurso tivesse sito tempestivamente interposto, seria, com absoluta certeza, provido." (SAVI, Sérgio. Responsabilidade civil por perda de uma chance. 3. ed. São Paulo: Atlas, 2012. p. 1).

${ }^{623} \mathrm{O}$ STJ, reiteradas vezes, já decidiu que cabe à defesa a demonstração do prejuízo pela ausência de intimação. Por todos, HC 177.195, $5^{\mathrm{a}}$ T., Rel. Min. Laurita Vaz, j. 26.8.2014. Merece reprodução, para demonstrar a incongruência do posicionamento, trecho do voto condutor de referido aresto: Quanto à alegação $b$ (nulidade devido à ausência de intimação para o ato deprecado na Comarca de Taboão da Serra), (...) efetivamente não resta demonstrado prejuízo para a Defesa, não se consubstanciando o ato deprecado em elemento que, por si só, fundou a condenação - conclusão baseada, na verdade, em todo conjunto probatório produzido do processo-crime."

${ }^{624}$ Saliente-se, por oportuno, que essa ideia de vincular, ainda que indiretamente, a matéria processual penal com o Direito Civil surge da leitura da obra de Gustavo Badaró (Processo penal, cit., p. 578), especificamente do seguinte excerto: “o 'prejuízo' não é um fato, mas sim uma perda de uma chance, da possibilidade de obter uma melhor posição processual."
} 
das bases que a formam pode ser de valia para compreensão da dificuldade de se estabelecer critérios para danos "em potencial".

Cumpre observar que antigamente, por força de uma visão fundada exclusivamente na teoria da equivalência das condições, o dano decorrente da perda de uma oportunidade de obter uma vantagem, ou de evitar um prejuízo, era indiferente aos olhos da doutrina e jurisprudência civil, sendo certo que a vítima suportava o ônus integral dessa chance perdida. ${ }^{625}$ Inexistia, portanto, a ideia de dano independente do resultado final.

A ideia de perda de uma chance, como dano ressarcível em matéria de indenização civil, remonta suas origens no droit civil francês do final do século XIX. ${ }^{626}$ De acordo com essa teoria, a chance perdida, representada por uma expectativa necessariamente hipotética, passa a ser considerada como um prejuízo à vítima, que será indenizada de acordo com o grau da oportunidade que lhe foi suprimida. ${ }^{627}$

O exemplo clássico de perda de uma chance, recorrentemente citado pelos civilistas, é aquele decorrente de negligência do advogado. Com efeito, cita-se, amiúde, o caso do procurador que deixa de interpor, no prazo legal, apelação em favor de seu constituinte, que, por sua vez, se encontra condenado em primeira instância. Não há como prever, com absoluta certeza, se o recurso seria provido, mas é possível sugerir que a vítima perdeu uma possibilidade real de obter um pronunciamento razoável. ${ }^{628}$ De igual forma, ocorre no caso do médico que, por negligência ou imperícia, deixa de diagnosticar uma doença de um paciente submetido aos seus cuidados, e pouco tempo depois tal paciente falece em razão daquela enfermidade. Diz-se, nessa hipótese, que eventualmente haveria a ocorrência da perda de uma chance de o paciente se recuperar, em razão da omissão do médico. ${ }^{629}$

São situações - as quais, analogamente, podem ser transportadas para o campo do prejuízo no processo penal - em que a vítima se encontra diante de uma encruzilhada, tendo em vista que, de um lado, quer ver reconhecida a lesão contra si, mas, de outro, carece de conhecimentos e meios para inferir, de forma conclusiva, se houve ou não causalidade. A doutrina da perda de uma chance existe justamente para promover os meios

\footnotetext{
${ }^{625}$ Cf. SAVI, Sérgio. Responsabilidade civil por perda de uma chance, cit., p. 2.

${ }^{626}$ MEDINA ALCOZ, Luis. La teoria de la perdida de oportunidad. Navarra: Thomson Civitas, 2007. p. 130.

${ }^{627}$ SILVA, Rafael Pettefi da. Responsabilidade civil pela perda de uma chance. 3. ed. São Paulo: Atlas, 2013. p. 13-14.

${ }^{628}$ MEDINA ALCOZ, Luis. La teoria de la perdida de oportunidad, cit., p. 67.

${ }^{629}$ Cf. FISCHER, David. Tort recovery for loss of a chance. Wake Forest Law Review, n. 605, 2001.
} 
para que essa vítima não sofra integralmente com o prejuízo, auxiliando-a diante das dificuldades probatórias. ${ }^{630}$

No Direito Civil, de forma geral, a solução dada à questão da indenização em decorrência da perda de uma chance é que ela somente seja aplicada quando a oportunidade perdida for considerada séria e real. ${ }^{631}$ Considerando o caráter patrimonial normalmente vinculado às questões cíveis, cabe ao julgador, utilizando regras de estatística e probabilidade, lançar mão de um raciocínio sobre o valor aproximado do êxito provável (caso não fosse perdida a chance), que permita, assim, seja quantificado o dano causado. Retomando novamente o exemplo da negligência profissional do procurador, RAFAEL PETEFFI DA SILVA exemplifica a aplicação da teoria: "toma-se um recurso intempestivo sobre o qual se conclui, fundado em percuciente pesquisa jurisprudencial, que retirou $60 \%$ da probabilidade da vítima reverter uma decisão desfavorável recebida em instância inferior. Se a vantagem esperada pela vítima com a total procedência da demanda judicial era equivalente a $\mathrm{R} \$ 100.000,00$, o valor da chance perdida pela conduta do réu consubstancia-se na importância de $\mathrm{R} \$ 60.000,00$, equivalente a $60 \%$ da vantagem esperada (...)."632

Conforme se verifica, a teoria da perda de uma chance, no Direito Civil, funda-se na capacidade de estipular, com base em uma estimativa probabilística, aquilo que a vítima deixou de ganhar em virtude do erro. Em verdade, o foco dos estudos, no âmbito privado, é encontrar critérios razoáveis para quantificar o dano reparável, sendo certo que a vantagem esperada pela vítima nunca será igualada àquela em que teria resultado esta chance, caso esta tivesse sido realizada, "pois nunca a chance esperada é igual à certeza realizada". ${ }^{633}$

Retornando à reflexão objeto do presente trabalho, seria possível "quantificar" o prejuízo sofrido pela parte em virtude do vício processual penal $?^{634}$ Nesse sentido, considerando a impossibilidade de saber ao certo o que teria acontecido se o ato processual

\footnotetext{
${ }^{630}$ MEDINA ALCOZ, Luis. La teoria de la perdida de oportunidad, cit., p. 79.

${ }^{631}$ SILVA, Rafael Pettefi da. Responsabilidade civil pela perda de uma chance, cit., p. 138. Na jurisprudência: "Na pert d'une chance, todavia, o fato ilícito e culposo deve contribuir, de forma direta, para que outrem perca uma chance de conseguir um lucro ou obter uma vantagem ou de evitar um prejuízo. Contudo, é necessário que a chance perdida seja real e séria." (TJRJ, Ap. Civel no 2003.001.16559, 6ª C., Rel. Des. Maldonado de Carvalho, j. 17.9.2003).

${ }^{632}$ SILVA, Rafael Pettefi da. Responsabilidade civil pela perda de uma chance, cit., p. 226.

${ }^{633}$ MARTINS-COSTA, Judith. Prefácio. In: SILVA, Rafael Pettefi da. Responsabilidade civil pela perda de uma chance, cit., p. xviii.

${ }^{634}$ A problemática não fica restrita ao Brasil: "Perhaps even more problematic in the trial versus structural error framework is the incorrect assumption that a reviewing court's only concern is whether error can be 'quantified'." (WICHT, James Edward. There is no such thing as a harmless constitutional error: returning to a rule of automatic reversal, cit., p. 85).
} 
fosse levado a efeito de forma regular, haveria alguma forma de calcular o grau de importância, de maneira minimamente objetiva, do erro em relação ao processo? De que forma mensurar quantitativamente, por exemplo, a lesão causada ao acusado pela inversão da ordem das perguntas formuladas a uma testemunha de acusação, em desacordo com o preceito do artigo 212 do Código de Processo Penal? ?35 $^{635}$

Parece difícil aceitar que no processo penal sejam adotados critérios semelhantes ao da teoria da perda de uma chance, rotineiramente aplicados às situações de responsabilidade civil. ${ }^{636}$ A "chance", no processo penal, constitui conduta (escrita ou falada), a qual deixou de ser praticada pela parte exclusivamente por conta de um vício vislumbrado durante a persecução penal. Divagar sobre a relevância de aludida "chance" para o deslinde final da causa é possível (embora de utilidade questionável), mas atribuir a ela um valor representativo de dano revela-se algo inexequível. ${ }^{637}$

Quando se está a tratar de atos processuais penais que, ao fim e ao cabo, podem gerar a supressão da liberdade de um indivíduo, torna-se perigoso especular acerca daquilo que poderia ter sido escrito ou falado pelas partes caso o Estado tivesse observado fielmente o ordenamento jurídico. Não cabe, com efeito, na hipótese supracitada, ao magistrado, deduzir se eram relevantes ou não algumas perguntas que eventualmente deixaram de ser feitas à testemunha em virtude do erro na inversão da ordem de inquirição. ${ }^{638}$ Houve, no caso, uma "chance" perdida, por culpa do próprio Estado, sendo impróprio fazer qualquer ilação sobre a relevância dessa chance. Para melhor adequação ao processo penal, poder-se-ia chamar essa "chance" de "oportunidade processual". 639

\footnotetext{
${ }^{635}$ Sobre o tema, eis a lição de Alexandre Morais da Rosa (Guia compacto do processo, cit., p. 197): “A atual redação [do artigo 212, CPP] não deixa dúvida acerca do papel do juiz no desenrolar da colheita da prova testemunhal, colocando-o no papel de mero espectador, sendo atribuído aos jogadores a formulação direta das perguntas (nos moldes do cross-examination norte-americano ou do esameincrociato, italiano)."

${ }^{636}$ Nesse sentido, cumpre rechaçar, por completo, ao menos no processo penal, a ideia de Antonio do Passo Cabral (Nulidades no processo moderno: contraditório, proteção da confiança e validade prima facie dos atos processuais, cit., p. 343-344) que defende a aplicação da proporcionalidade entre meios e fins na análise da atipicidade a posteriori.

${ }^{637}$ Pela pertinência, trecho de julgamento antigo da Suprema Corte merece ser reproduzido: "Constitutional rights are too fundamental and absolute to allow courts to indulge in nice calculations as to the amount of prejudice arising from their denial.” (Glasser v United States, 315 U.S. 60, 76 (1942)).

${ }^{638}$ Por essa razão, parecem estar equivocados os diversos julgamentos sobre o tema, já que exigem uma demonstração efetiva do que poderia ter sido perguntado se a ordem da inquirição fosse respeitada. Esse ônus jamais pode ser imposto ao acusado. Por todas, apenas para ilustrar o entendimento jurisprudencial, segue o trecho de julgamento proferido pelo STJ: "Conforme bem salientou o douto parecer ministerial, a Defesa não logrou demonstrar o gravame que lhe foi causado em decorrência da inquirição de testemunhas diretamente pelo magistrado, tampouco demonstrou como a prática influiu na apuração da verdade substancial." (HC 237.782, 5 T., Rel. Min. Laurita Vaz, j. 5.8.2014).

${ }^{639}$ James Goldschmidt (Teoría general del proceso. Trad. Leonardo Prieto Castro. Barcelona, Editorial Labor, 1936. p. 53) expõe com maestria essa oportunidade processual (para ele, chance processual) e a
} 
Cumpre esclarecer um ponto de extrema importância: à parte cabe comprovar que houve a perda de oportunidade processual efetiva gerada pelo vício, e não, como preferem alguns, a comprovação do prejuízo em decorrência dessa perda. Apesar da aparente similitude teórica entre as ideias, na realidade elas se revelam muito distintas em termos práticos.

É porque, de forma iterativa, nossos tribunais têm exigido a comprovação, pela parte, do prejuízo efetivo gerado pela perda da oportunidade. ${ }^{640}$ Como visto, a demonstração desse prejuízo, para além de ser uma carga probatória imposta indevidamente à parte, torna-se impossível de ser plenamente identificável. À parte, se é que a ela cabe algum ônus, é imperioso alegar e fundamentar que o vício gerou a perda de uma oportunidade processual. A prova da lesão decorrente dessa perda, por outro lado, não pode ficar a cargo da parte.

Ao se organizarem as ideias no âmbito de uma decisão racional para aferição do prejuízo, constata-se que a perda de uma oportunidade processual funciona como um critério indicador de lesão. Se, por um lado, como regra, o juiz deve expor as razões pelas quais o vício, em cada caso específico, afasta a presunção de lesão já existente, por outro, a verificação de uma oportunidade perdida impossibilita o afastamento dessa presunção inicial. ${ }^{641}$

Importante notar que o simples fato de haver a privação da oportunidade processual não permite concluir, automaticamente, pela existência do prejuízo exigido pelo artigo 563,

dispensa do ônus processual para demonstrá-la: "La expectativa de una ventaja procesal y, en último término, de una sentencia favorable, la dispensa de una carga procesal y la posibilidad de llegar a tal situación por la realización de un acto procesal, constituyen los derechos en el sentido procesal de la palabra francesa: chances (...) las expectativas de una ventaja procesal pueden compararse con los derechos relativos, porque hay por parte del juez vinculación de satisfacerlas; las dispensas de cargas procesales se parecen a los derechos absolutos en que ponen a salvo la libertad de la parte interesada contra cualquier perjuicio; por último, las posibilidades de actuar con éxito en el proceso se corresponden totalmente con los derechos potestativos e constitutivos."

${ }^{640} \mathrm{O}$ problema não tem passado despercebido também pela doutrina norte-americana, que entende ser inadmissível exigir da parte a demonstração efetiva do prejuízo: "Judging from this passage alone, the Chief Justice would seem not only to impose the burden of proof on the petitioner, but also to require him to show 'actual prejudice'. Yet this reference to 'actual prejudice' must be handled with some care, since it has the potential to transform Brecht rule into something it is not (...) Brecht might thus require a petitioner to show (on the assumption that the petitioner bears the burden of proof) only that the error possibly could have affected the verdict, no that it probably would have." (Harmless error in Federal Habeas Corpus After Brecht v. Abrahamson, cit., p. 175-176).

${ }^{641}$ Embora não se entenda que o prejuízo esteja diretamente vinculado à influência do deslinde final da causa, é de consignar a lição de Ada Pellegrini Grinover, que concorda que a perda da faculdade pode ser feita por uma operação lógica, ao asseverar que "isso não significa que em todos os casos se exija a produção de prova da ocorrência de prejuízo; normalmente essa demonstração se faz através de simples procedimento lógico, verificando-se se a perda da faculdade processual (...) influenciou no resultado final do processo." (O processo: III Série: estudos e pareceres de processo penal, cit., p. 113). 
pois a configuração deste dependerá dos outros critérios aqui analisados. ${ }^{642}$ É a lesão, a qual inicialmente era presumida com a inobservância processual, que se aperfeiçoa diante da constatação de uma real oportunidade perdida.

\subsubsection{O erro proposital da parte como condição de inexistência do prejuízo}

Para se levar adiante o estudo sobre a decisão racional para avaliação da existência do prejuízo, não há como ignorar os casos em que a própria parte pleiteante da nulidade seja a causadora do ato viciado. Na esteira do brocardo latim, nemo audit propriam turpitudinem allegans, afigura-se necessário entender se a torpeza, alegada em causa própria, altera a compreensão das regras - e das presunções - relacionadas ao prejuízo no processo penal.

O artigo 565 do Código de Processo Penal materializa em parte a ideia supracitada, ao dispor que "nenhuma das partes poderá arguir nulidade a que haja dado causa, ou para que tenha concorrido, ou referente a formalidade cuja observância só à parte contrária interesse." Conhecido usualmente como princípio do interesse, a doutrina o tem tratado de forma completamente desvinculada do prejuízo, como se um não interferisse na aplicação do outro.

Insta notar, antes de prosseguir, que o dispositivo legal transcrito (simplificado, doutrinariamente, para princípio do interesse) traz duas hipóteses distintas para traduzir a falta de interesse da parte para suscitar a nulidade: (i) quando ela própria haja dado causa, ou concorrido, para a realização do ato de maneira viciada; (ii) quando a formalidade, que o pedido de nulidade quer ver reestabelecido, somente interesse à parte contrária. Interessa, ao presente trabalho, tratar apenas da primeira hipótese, a qual parece manter uma estreita ligação com a concepção do prejuízo. Já a segunda parte está atrelada estritamente ao interesse postulatório de eventual invalidação do ato, não encontrando terreno no campo do prejuízo.

Pois bem. Ao pensar em prejuízo, fica difícil imaginá-lo sem uma "vítima"; ou seja, é inconcebível reconhecer um prejuízo (financeiro, processual, etc.) sem que se saiba quem

\footnotetext{
${ }^{642}$ Leonardo Costa de Paula (As nulidades no processo penal. Curitiba: Juruá, 2013. p. 49), não sem certa ironia, preceitua que "verifica-se a tendência de proporcionar poder ilimitado aos juízes de cognição ou recursais para analisar se haverá prejuízo na inversão de atos processuais, na ausência de citação para prática de atos, ou qualquer forma não prevista em lei. Dessa forma, seria necessário proporcionar ao magistrado um aparato tal qual uma bola de cristal, pois, como seria ele capaz de realizar uma análise hipotética se um ato praticado de acordo com a lei ou com a forma híbrida estipulada pelo juízo influenciaria, ou não, o convencimento de certa tese defensiva ou acusatória de maneira diversa? Pensar que há a possibilidade de uma análise hipotética do prejuízo no caso concreto é dotar o juiz de poder de intuição, sexto sentido judicial e policial, já que denota um ato de fé ou de relação empática do juiz."
} 
ou o que o sofreu. Muito embora haja casos em que esse polo lesivo esteja diluído ou seja de difícil identificação, a ideia do prejuízo remete normalmente a um dano imposto a alguém ou a algo.

Resta saber, por outro lado, se esse prejuízo é verificável ainda que a “vítima” tenha auxiliado no ato que o gerou. À primeira vista, e como regra geral, a participação da pessoa lesada pouco importa para o aperfeiçoamento do prejuízo. O operador de uma bolsa de valores que investe, em favor próprio, em ação cujo valor desvalorizou acintosamente no dia seguinte, inegavelmente obteve um prejuízo. Conquanto o investidor tenha sido responsável pela compra das ações, não se há de negar que arcou ele com um prejuízo patrimonial decorrente da perda de seu valor.

O que ocorre com certa frequência, todavia, e é isso que o dispositivo legal do artigo 565 do CPP procura coibir, é a suposta "vítima" se beneficiar maliciosamente do seu próprio ato para obter o reconhecimento de um prejuízo. A hipótese do artigo 256 , do diploma processual pátrio, é sobremaneira ilustrativa, ao impedir que a suspeição seja reconhecida quando a parte injuriar o juiz ou der motivo, propositalmente, para criar a situação de suspeição. ${ }^{643}$ Nesse caso, fica patente que, embora se vislumbre uma possível quebra de imparcialidade do juiz, inexistirá nulidade, pois a parte foi responsável pelo ato viciado.

Há de se convir que, da forma como é estudada atualmente, a questão não repercute, de maneira alguma, na decisão acerca da incidência do prejuízo. É dizer: para fins de verificação do pas de nullité sans grief, de nada importaria, a se coadunar com a doutrina tradicional, que a parte tivesse gerado, ou contribuído para gerar a imperfeição do ato, sendo certo que o reconhecimento do prejuízo se daria independentemente desse fato.

Não é esse o melhor entendimento. Ao ser suscitada uma nulidade, imprescindível que o julgador verifique, para fins de reconhecimento do prejuízo, se a parte pleiteante teve participação deliberada, e mal-intencionada, na ocorrência do vício. Se sim, parece impossível falar em prejuízo àquela parte. É que à noção de prejuízo processual penal deve estar ínsita a ideia de que o erro se dê em virtude de fatos alheios à vontade da parte supostamente prejudicada. Condutas maliciosas ou ardilosas, por óbvio, não podem ser consideradas prejudiciais aos seus próprios perpetradores.

\footnotetext{
643،“Art. 256. A suspeição não poderá ser declarada nem reconhecida, quando a parte injuriar o juiz ou de propósito der motivo para criá-la."
} 
Não fosse apenas pela correta teorização da categoria do prejuízo, tal posicionamento assumiria relevância prática. Como é cediço, há intensa discussão acerca das espécies de nulidades que estariam sujeitas à regra do artigo 565 do CPP, havendo quem defenda ser a vedação apenas aplicável às nulidades relativas, uma vez que as absolutas, por tratarem de interesses públicos, não comportariam qualquer exame de conveniência. $^{644}$

Independentemente da discussão acerca da artificialidade relacionada à distinção entre nulidades absolutas e relativas, é fato que a aplicabilidade da regra do interesse adstrita somente a alguns casos gera um quadro curioso. De se imaginar a hipótese em que, no dia designado para audiência, o acusado não comparece ao ato, sendo que no dia seriam ouvidas as testemunhas de acusação. O magistrado toma conhecimento, por meio de escuta judicialmente autorizada, que o acusado estava ciente do ato, confessando no diálogo que somente não iria comparecer para criar uma nulidade no processo. Estudado sob o viés do interessado em suscitar a invalidade, nesse caso hipotético, inexistiria qualquer óbice para declaração da nulidade, pois se trata de vício que vulnera interesse público, cabendo ao juiz, de ofício, reconhecê-la.

Por isso, é fundamental que a torpeza da parte, e de seu representante, seja examinada também para efeitos de aferição do prejuízo, e não somente quanto à parte legitima para pleitear a nulidade. Não há dúvidas de que o caso relatado, a despeito de retratar uma hipótese, em tese, de nulidade absoluta, descreve conduta ardilosa da parte, sendo necessário reconhecer a não incidência do prejuízo. De forma contrária, estar-se-ia admitindo espécie de "auto-prejuízo malicioso" com intuito de obtenção de vantagens processuais.

Impende esclarecer, no entanto, que a conduta praticada pela própria parte requerente da nulidade, para fins de exame do prejuízo, somente terá alguma consequência quando verificadas as seguintes situações: (i) a parte, ou seu representante, pretendia de fato, e intencionalmente, causar a imperfeição da forma processual; (ii) existem elementos suficientes para atestar que o defeito foi gerado, além de intencionalmente, com emprego de algum meio ardiloso ou fraudulento pela parte ou seu representante.

\footnotetext{
${ }^{644}$ Ricardo Gloeckner (Nulidades no processo penal: introdução principiológica à teoria do ato processual irregular, cit., p. 292) preceitua que "a valência dos princípios constitucionais não permite a sua relativização mediante regras de caráter infraconstitucional.”
} 
Reunidos esses requisitos, é possível concluir pela impossibilidade de a parte ver reconhecido um prejuízo contra si. $^{645}$ A torpeza da parte, portanto, possibilita ao magistrado afastar a presunção de lesão inicialmente existente em virtude da inobservância da forma, impossibilitando, por consequência, o reconhecimento da nulidade.

\subsubsection{O prejuízo específico do Ministério Público}

No decorrer desse estudo, muito se focou no papel das formas para assegurar as garantias do acusado no processo penal. Aliás, grande parte dos exemplos citados diz respeito aos vícios cometidos em desfavor da defesa, gerando uma discussão sempre em torno do possível prejuízo arcado pelo acusado. ${ }^{646}$ Não há como negar, no entanto, existirem casos nos quais a nulidade é suscitada pela acusação, devendo obrigatoriamente ser estudado o prejuízo sob esse ângulo específico.

Antes de prosseguir, cumpre fazer uma reflexão inicial. Afinal, quando o Ministério Público requer o reconhecimento de uma nulidade, à luz do artigo 563 do Código de Processo Penal, o prejuízo é de quem? Seria tal prejuízo da instituição, da parte-acusação, ou da vítima do fato apurado no processo? As indagações, que à primeira vista podem parecer simples, ganham contornos mais complexos a partir do momento em que a o intérprete se vê diante de um problema prático.

BINDER entende que o descumprimento das formas do processo penal jamais afeta um interesse próprio do Ministério Público. Extrai-se de sua obra que o órgão ministerial seria uma magistratura especializada, que teria como função primordial o fortalecimento da necessária tutela judicial das vítimas, sendo certo, ademais, que, na qualidade de funcionário público, o promotor deveria estar restrito a atuar conforme a competência conferida a ele em lei. O vício afetará a atuação do Ministério Público, ainda segundo o doutrinador argentino, apenas na medida em que os interesses da vítima ou do próprio imputado forem afetados. ${ }^{647}$

\footnotetext{
${ }^{645}$ A doutrina italiana utiliza nome de abuso do processo: "L'abuso del processo consiste in um vizio, per sviamento, della funzione, ovvero in uma froda ala funzione, e si realiza allorchè un diritto o una facoltà processuale astrattamente li riconosce all'imputato, il quale non può in tale caso invocare la tutela di interessi che non sono stati lesi e che non erano in realtà effettivamente perseguiti." (FANULI, Giuseppe Luigi. Le nullità nel processo penale, cit., p. 141).

${ }^{646}$ Até porque, como observa Antonio Tovo Loureiro (Nulidades e limitação do poder de punir: análise de discurso de acórdãos do Tribunal de Justiça do Rio Grande do Sul, cit., p. 51) após realizar um levantamento demonstrativo nos tribunais pátrios, cerca de $90 \%$ das nulidades suscitadas partem da defesa.

${ }^{647}$ BINDER, Alberto. El incumplimiento de las formas procesales, cit., p. 132.
} 
Note-se que, pela posição de BINDER, a atuação do Ministério Público estaria concentrada em uma função meramente representativa da vítima do delito. Esse entendimento, a despeito de sua razoabilidade aparente, não parece ser correto. A uma, porque o papel da vítima, em um processo penal verdadeiramente acusatório, há de ser extremamente mitigado, de modo a evitar a prolação de decisão judicial influenciada por fatores emocionais e vingativos. ${ }^{648} \mathrm{Se}$ assim é, as formas não podem estar a serviço dos interesses exclusivos da vítima. A duas, porque quando se está a falar em representação da vítima, muitas vezes esta é oculta ou difusa, dando margem a que o Ministério Público possa sustentar o prejuízo em nome da "coletividade".

É por essa última razão, outrossim, que se deve afastar também a ideia muito difundida de que o prejuízo, em hipóteses pleiteadas pelo Ministério Público, seria do Estado-sociedade. Referida posição estaria fundada na concepção segundo a qual o Parquet atuaria como custos legis no processo penal, o que sugeriria a sua imparcialidade, ${ }^{649}$ bem como um interesse único de garantir a correta aplicação da lei. ${ }^{650} \mathrm{O}$ prejuízo relacionado às nulidades, nesse raciocínio, estaria vinculado a um interesse coletivo, de toda a sociedade, pela higidez do ordenamento penal e correta aplicação da "justiça".

É preciso lembrar, como sustentado ao longo do trabalho, que normalmente a atribuição de interesses abstratos, até de certa forma impalpáveis, acabam por promover um espaço discricionário impróprio e ilegítimo dentro do processo penal. Concluir, desta feita, que o Ministério Público apenas objetiva a correta prestação jurisdicional, e que, portanto, o prejuízo de eventual vício suscitado por esse órgão estaria ligado ao interesse de toda a sociedade, não soluciona a questão; antes, a deixa ainda mais confusa.

Não se afigura viável, com efeito, deixar o conteúdo do prejuízo a critério, ainda que indireto, da sociedade. Em última instância, a vontade da sociedade não pode ser outra coisa que não o cumprimento exato e rigoroso da lei. Afinal, a lei nasce, em tese, da

\footnotetext{
${ }^{648}$ Sobre o papel nocivo que a vítima pode assumir dentro do processo penal, cf. CARVALHO, Salo de. As reformas parciais no processo penal brasileiro. In: CARVALHO, Amilton Bueno de; CARVALHO, Salo de (Orgs.). Reformas penais em debate. Rio de Janeiro: Lumen Juris, 2005.

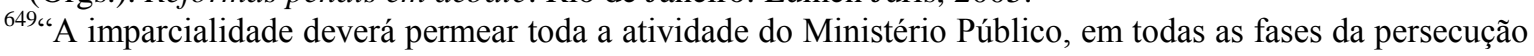
penal, incluindo a fase pré-processual, reservada às investigações." (PACELLI, Eugenio. Curso de processo penal, cit., p. 462).

${ }^{650}$ É esse o entendimento de Tourinho Filho (Processo penal. 34. ed. São Paulo: Saraiva, 2012. v. 2, p. 423) para quem "essa posição neutral [do Ministério Público], essa imparcialidade, é também acentuada por Fenech, ao afirmar que o Ministério Público não tem por missão ir contra o imputado, senão pedir a atuação da pretensão em relação a ele, devendo agir no interesse da verdade e da justiça (...) o Ministério Público é representante da lei. É a encarnação do espírito da lei."
} 
própria vontade da sociedade. ${ }^{651}$ Por raciocínio lógico, afirmar que o prejuízo está atrelado a um interesse do Estado-sociedade, seria o mesmo que defender um sistema de nulidades formalista, sem espaço algum para deslizes. Fora isso, seria apenas uma interpretação casuística do Ministério Público do que de fato é prejudicial à sociedade.

Por isso é imprescindível aceitar, de vez por todas, que o Ministério Público, no âmbito do processo penal, atue sempre na qualidade de parte. ${ }^{652} \mathrm{E}$, mais: quando atua na posição processual de autor o Ministério Público é - e deve ser - parcial. ${ }^{653}$ Não se há de negar que tal órgão figure como parte especial, ${ }^{654}$ tendo em vista que está vinculado à defesa da ordem constitucional. Porém, não deixa de ser parte. Tais esclarecimentos são essenciais para determinação do real prejuízo suportado pelo Ministério Público em face do vício processual.

Isso porque, a nulidade deve ser estudada sob a perspectiva do Ministério Públicoparte. Somente a partir desse enfoque específico poderá o magistrado analisar um eventual prejuízo e, por via de consequência, a necessidade de declarar a ineficácia do ato viciado. Descarta-se, portanto, no exame do pas de nullité sans grief, qualquer interesse institucional do Ministério Público ou mesmo da vítima. ${ }^{655}$

Significa dizer que a imperfeição somente causará algum prejuízo ao Ministério Público na medida em que ela o restringir de atuar como parte processual. A defesa intransigente da separação entre as funções de julgar e acusar mostra-se extremamente salutar para amadurecimento de um modelo genuinamente acusatório, exigindo-se a proteção das formas aptas a assegurar a atuação do órgão ministerial como parte dialética no processo penal. ${ }^{656}$ Destaque-se que um processo penal no qual o juiz procura suprir os

\footnotetext{
${ }^{651}$ Cumpre, aqui, trazer o pensamento filosófico de Paulo Bonavides, o qual traz a lembrança de que o cumprimento da lei remete à liberdade da sociedade: "A legalidade, compreendida pois como a certeza que têm os governados de que a lei os protege ou de que nenhum mal portanto lhes poderá advir do comportamento dos governantes, será então sob esse aspecto, como queria Monstesquieu, sinônimo de liberdade." (Ciência política. 10. ed. São Paulo: Malheiros Ed., 2003. p. 147).

${ }^{652}$ Cf. NORONHA, Edgard Magalhães. Curso de direito processual penal, cit., p. 133.

${ }^{653}$ Gustavo Badaró (Processo penal, cit., p. 197) ensina que a parcialidade do Ministério Público é essencial para a dialética do processo acusatório.

${ }^{654}$ Cf. FELDENS, Luciano. Ministério Público, processo penal e democracia: identidade e desafios. In: PRADO, Geraldo; MALAN, Diogo (Coords.). Processo penal e democracia. Rio de Janeiro: Lumen Juris, 2009. p. 328.

${ }^{655} \mathrm{O}$ entendimento encontra-se também mais consentâneo com a própria norma (art. 563, CPP), que exige um prejuízo à parte.

${ }^{656}$ “'́́ salutar à noção complementar do processo acusatório que separar quem acusa de quem julga implica separar, também, quem julga de quem acusa, isto é: se a atividade não pode travestir-se de acusadora, a recíproca também é verdadeira e, entre os órgãos auxiliares do juízo, não se inclui o Ministério Público." (VIEIRA, Renato Stanziola. Paridade de armas no processo penal. Brasília: Gazeta Jurídica, 2014. p. 117).
} 
defeitos da acusação, sem haver a necessária independência das partes, acaba por ser também extremamente prejudicial ao próprio acusado. ${ }^{657}$

Ainda que se assuma a perspectiva de parte-processual, há quem entenda existirem largas limitações para a alegação de nulidade por parte do Ministério Público. Nesse sentido, GLOECKNER chega a sugerir que é defeso à acusação suscitar a nulidade quando houver a possibilidade de advir édito absolutório. Tal restrição seria um desdobramento, prossegue o autor, de um suposto princípio da escusa absolutória. Para ele, é melhor aceitar a limitação da atuação da parte-acusadora a admitir a manutenção da persecutio criminis desprovida de evidências prováveis do cometimento do delito. ${ }^{658}$

$\mathrm{O}$ argumento, embora sedutor, não pode prevalecer. ${ }^{659}$ Consoante já se disse, a nulidade não poderá ficar integralmente vinculada a uma possível resolução da causa. Se isso é verdade para a defesa, também deve servir no caso do Ministério Público. A assumir que o vício seria indiferente diante de uma eventual decisão absolutória, o magistrado deixa de conferir a devida importância para o ato em si, olvidando que aquele mesmo ato, se corretamente praticado, poderia alterar seu convencimento no momento da prolação da decisão.

Afora isso, parece que eventual decisão absolutória não impede o reconhecimento de nulidade a pedido do Ministério Público. A título de exemplo, cite-se a sentença absolutória, cuja carência de motivação não permite sequer verificar se os argumentos levantados pela acusação foram devidamente analisados. ${ }^{660} \mathrm{O}$ Ministério Público, como parte que é, tem o direito de conhecer os motivos que levaram o julgador a se pronunciar de tal ou qual maneira, bem como as razões para afastar um possível pleito condenatório. Isso tudo porque, no escólio de MAGALHÃES, “as atividades dos participantes do contraditório somente adquirem significação se forem efetivamente consideradas na decisão."661 O artigo 93, IX, da Constituição Federal, ao prever a exigência de

${ }^{657}$ Cf. GLOECKNER, Ricardo Jacobsen. Nulidades no processo penal: introdução principiológica à teoria do ato processual irregular, cit., p. 552.

${ }^{658}$ GLOECKNER, Ricardo Jacobsen. Nulidades no processo penal: introdução principiológica à teoria do ato processual irregular, cit., p. 553.

${ }^{659}$ A despeito de equiparar, para fins de nulidade, o interesse do Ministério Público ao interesse da sociedade, tese essa com a qual não se concorda, Cezar Roberto Bittencourt traz um ponto importante para debate: "É, no mínimo, uma posição questionável entender que a favor do indivíduo tudo é permitido, esquecendo-se que no outro polo da relação processual encontra-se a sociedade, representada pelo Ministério Público, que também tem o direito de receber um tratamento isonômico." (Tratado de direito penal. 17. ed. São Paulo: Saraiva, 2012. v. 1, p. 669).

${ }^{660}$ Nesse sentido, por todos, TJSP, Apel. 0005856-48.2008.8.26.0362, 16a C., Rel. Des. Souza Nucci, j. 20.3.2012.

${ }^{661}$ GOMES FILHO, Antonio Magalhães. A motivação das decisões penais, cit., p. 145. 
fundamentação das decisões proferidas por órgãos judiciais, não distingue em favor de quem (de que partes) essa garantia deve atuar.

É verdade que a forma, no processo penal, assume função precípua de proteção do acusado contra eventuais arbitrariedades. Essa deve ser, sem dúvida, a feição mais relevante do ato processual perfeito. Contudo, não se pode cerrar os olhos para o fato de que a forma encontra em si outros papeis, ainda que menos importantes, tais como o de proporcionar meios para a imposição de uma pena (constitucionalmente) legítima por parte do Estado.

Não se há de discordar que a casuística tem sido pródiga em fornecer exemplos de casos em que o vício arguido pela acusação gera genuíno prejuízo ao acusado. ${ }^{662}$ Por exemplo, a audiência de instrução realizada sem a presença do representante do Ministério Público tem sido objeto, já há muito, de intensos debates jurisprudenciais. ${ }^{663}$ Não raras vezes, o tribunal reconhece aludida nulidade, mesmo quando existente sentença absolutória. Por maior que seja o transtorno (prejuízo processual, de fato) causado ao acusado, é preciso reconhecer uma lesão, nessa hipótese específica, à parte-acusadora. ${ }^{664}$ É esse o preço que, por vezes, o acusado precisa pagar para ter garantido, por sua vez, um processo justo, em que garantias constitucionais, tais como o contraditório, sejam rigorosamente observadas para ambas as partes.

A despeito dessa aparente paridade de tratamento das partes, torna-se imprescindível, nesse ponto, lançar algumas considerações adicionais. Reconhecer que há casos nos quais a parte-Ministério Público pode alegar um prejuízo, não significa necessariamente dizer que o juiz deverá fundamentar, com base nos mesmos standards argumentativos, os casos suscitados por ambas as partes.

\footnotetext{
${ }^{662}$ Apenas como exemplo, de se remeter ao precedente do TJRS: (Apel. Cr. 70053357984, $7^{\text {a }}$ C., Rel. Des. Naele Ochoa Piazzeta, k. 19.9.2013), no bojo do qual se decidiu anular o processo, a despeito de sentença absolutória, em que a vítima não havia sido ouvida no decorrer da instrução: "O indeferimento [de oitiva da vítima] (...) impede o Ministério Público de produzir substratos a fim de que veja implementado seu ônus previsto no caput, do artigo 156, do Estatuto Penal Adjetivo."

${ }^{663}$ Nesse sentido, no STJ: HC 79.712, 6 ${ }^{a}$ T., Rel. Min. Marilza Maynard, j. 21.11.2013; No STF: RHC 59.674, $1^{\text {a }}$ T., Rel. Ministro Soares Muñoz, j. 2.3.1982.

${ }^{664}$ Aury Lopes Junior (Direito processual penal e sua conformidade constitucional, cit., v. 2, p. 428), ao citar esse exemplo, preceitua que "é manifesta a existência de um defeito insanável, que deverá dar lugar a uma decisão anulatória de todo o processo, com a necessária repetição dos atos (e desentranhamento daqueles feitos com defeito)." Gloeckner (Nulidades no processo penal: introdução principiológica à teoria do ato processual irregular, cit., p. 295) adverte que pode haver também um prejuízo ao próprio acusado pela ausência do membro do Ministério Público na audiência: "Para que se tenha um sistema devidamente acusatório, necessário que o juiz se mantenha distante da produção probatória. A ausência do Ministério Público leva alguns juízes a produzir prova para a acusação, até mesmo de forma inconsciente."
} 
Já se ponderou, nesse mesmo capítulo, que cabe ao juiz (e não às partes) o ônus de encontrar argumentos para afastar a presunção inicial de lesão gerada pela inobservância das formas. Esclareça-se que o defeito processual, para caracterização do prejuízo ao acusado, não precisa estar diretamente relacionado à sua atuação como parte. Daí decorre o acertado entendimento de que poderá incidir prejuízo (e, eventual nulidade) em detrimento do indivíduo por conta de atos praticados no decorrer de inquérito policial, ${ }^{665}$ ou mesmo em situações nas quais o vício atinge garantias desvinculadas da parte (v.g. uso impróprio de algemas).

De outro modo, o exame para aferição do prejuízo sofrido pelo Ministério Público deve ficar adstrito somente a possíveis lesões relacionadas à parte-acusação. O magistrado deve aquilatar, destarte, se as formas aptas a permitirem uma atuação equânime das partes foram respeitadas; se sim, prejuízo inexistirá. Isso de nenhuma maneira significa uma vedação para que o representante ministerial pleiteie nulidades em favor do acusado. $\mathrm{Na}$ qualidade de fiscal da Constituição não só pode, como deve, assegurar as garantias do acusado. Porém, nesse caso, embora o pedido seja de iniciativa do Ministério Público, o prejuízo será do acusado.

\footnotetext{
${ }^{665}$ Não se desconhece a ausência de unanimidade em relação à matéria, tendo o STF inclusive adotado o posicionamento de que "o inquérito policial é peça meramente informativa e dispensável e, com efeito, não é viável a anulação do processo penal em razão das irregularidades ali detectadas, porquanto as nulidades processuais dizem respeito, tão somente, aos defeitos de ordem jurídica que afetam os atos praticados durante a ação penal.” (AgRg no RE 654.192/PR, 2 ${ }^{\mathrm{a}}$ T., Rel. Min. Gilmar Mendes, j. 22.11.2011). Todavia, com o respeito devido, não se pode conceber um processo penal no qual inexistem limitações impostas ao Estado durante a fase investigativa. Para um estudo mais aprofundado acerca das necessárias barreiras impostas ao poder de investigação estatal, cf. SAAD, Marta. O direito de defesa no inquérito policial. São Paulo: Ed. Revista dos Tribunais, 2004.
} 


\section{CONCLUSÃO}

À vista dos estudos realizados no decorrer do presente trabalho, cumpre extrair as seguintes conclusões:

1. A compreensão do real significado da instrumentalidade das formas exige necessariamente uma reflexão sobre a função do instrumento-processo no âmbito do ordenamento jurídico;

2. O processo penal não constitui apenas instrumento de punição estatal; antes e, sobretudo, ele se porta como freio do poder punitivo do Estado, que protege o acusado contra a imposição de uma pena ilegítima;

3. A forma do ato, inserido em um processo penal constitucional, ostenta particular relevância, tendo em vista que atua como genuína garantia de que a persecução penal seguirá um caminho pré-fixado em lei, bem como impede a extrapolação do poder punitivo;

4. O modelo tradicional das nulidades, adotado no processo penal brasileiro, precisa ser revisto para se adequar à realidade atual, posterior à Constituição de 1988. Nesse sentido, torna-se imperioso superar o aspecto decisionista de reconhecimento das nulidades, típico de sistemas inquisitoriais, de modo a reestabelecer um maior respeito às formas processuais;

5. As categorias ligadas à matéria das nulidades - tais como as nulidades absolutas e nulidades relativas -, importadas diretamente do processo civil sem a devida cautela, são confusas e formam um verdadeiro caos teórico. Em virtude desse fato, hodiernamente não há qualquer previsibilidade quanto à aplicação das respostas aos vícios processuais;

6. A regra - e não princípio - do prejuízo, vinculada às nulidades processuais, insere-se nesse contexto de desarranjo teórico, sendo ela utilizada de forma equivocada e generalizada para permitir a flexibilização das formas pelos tribunais pátrios;

7. A proposição de um modelo racional de aplicação do prejuízo, específico para o processo penal, constitui uma saída para evitar a discricionariedade desenfreada que se verifica atualmente na matéria de nulidades; 
8. Na construção do modelo racional, forçoso criar uma separação teórica entre as ideias de lesão e prejuízo. A lesão às partes ocorrerá sempre que se verificar a inobservância da forma processual (ato atípico), o que não acarreta, automaticamente, o reconhecimento de um prejuízo. O prejuízo, por outro lado, para efeitos do artigo 563 do Código de Processo Penal, exige a existência de uma lesão somada a outros requisitos específicos;

9. O ônus argumentativo para definir se em cada caso concreto a lesão presumida inicialmente não gerou um prejuízo é obrigatoriamente do magistrado, pois cabe a ele administrar a legalidade da persecução penal. Há, nesse caso, uma inversão de sinais, cabendo ao julgador consignar as razões, por meio de uma operação lógica e racional, para justificar não ter o vício afetado a função da forma desrespeitada;

10. Considerando que, em muitas hipóteses, a deformidade do ato não permite saber se seu resultado poderia ser diverso daquele de fato ocorrido, faz-se necessária a aplicação do critério da perda de uma oportunidade processual. A chance perdida pela parte exige do magistrado o reconhecimento do prejuízo, salvo se a hipótese específica impuser um conflito com algum outro critério estabelecido para aferição do prejuízo;

11. A torpeza da parte, em regra, afasta a ocorrência de prejuízo, razão pela qual o ato, mesmo atípico, manterá sua eficácia;

12. O prejuízo, suscitado pelo Ministério Público, somente se verificará em hipóteses específicas. Ao magistrado cabe, para reconhecimento da nulidade, observar se o vício impossibilitou o Ministério Público de atuar como parte no processo, desconsiderando, para tais fins, qualquer argumento de interesse da vítima ou da coletividade; e

13. Os critérios de aferição do prejuízo, se corretamente aplicados, certamente minimizarão o decisionismo exacerbado atrelado à matéria das nulidades no processo penal e, ao mesmo tempo, garantirão um maior respeito aos direitos fundamentais do acusado. 


\section{REFERÊNCIAS}

ALEXY, Robert. Teoria da argumentação jurídica. Trad. Zilda Hutchinson Schild Silva. São Paulo: Landy, 2001.

. Teoria dos direitos fundamentais. 2. ed. Trad. Virgilio Afonso da Silva. São Paulo: Malheiros Ed., 2012.

ALONSO, Aragoneses. Instituiciones de derecho procesal penal. 5. ed. Madrid: Rubi Artes Graficas, 1984.

ALVIM, José Eduardo Carreira. Elementos de teoria geral do processo. 2. ed. Rio de Janeiro: Forense, 1993.

ANULI, Giuseppe. Le nullità nel processo penale. Milano: Giuffre, 2013.

ARMENTA DEU. Teresa. Lecciones de derecho procesal penal. 3. ed. Madrid: Marcial Pons, 2007.

ASSIS, Maria Thereza Rocha de. A prova por indícios. São Paulo: Saraiva, 1994.

ÁVILA, Humberto. Repensando o princípio da supremacia do interesse público. Revista Trimestral de Direito Público, São Paulo, n. 24, p. 159-180, 1998.

Teoria dos princípios: da definição à qualificação dos princípios jurídicos. 3. ed. São Paulo, 2004.

AVOLIO, Luiz Francisco Torquato. Provas ilícitas: interceptações telefônicas, ambientais e gravações clandestinas. 3. ed. São Paulo: Ed. Revista dos Tribunais, 2003.

AZEVEDO, Antonio Junqueira de. Negócio jurídico: existência, validade e eficácia. 4. ed. São Paulo: Saraiva, 2010.

BADARÓ, Gustavo Henrique Righi Ivahy. A garantia do juiz natural no processo penal. 2010. Tese (Livre-Docência) - Faculdade de Direito da Universidade de São Paulo, 2010.

Ônus da prova no processo penal. São Paulo: Ed. Revista dos Tribunais, 2003.

Processo penal. Rio de Janeiro: Campus: Elsevier, 2012.

BANDEIRA DE MELLO, Celso Antonio. Curso de direito administrativo. 26. ed. São Paulo: Malheiros Ed., 2009. 
BARBOSA MOREIRA, José Carlos. Citação de pessoa falecida. In: BARBOSA MOREIRA, José Carlos. Temas de direito processual. São Paulo: Saraiva, 1994.

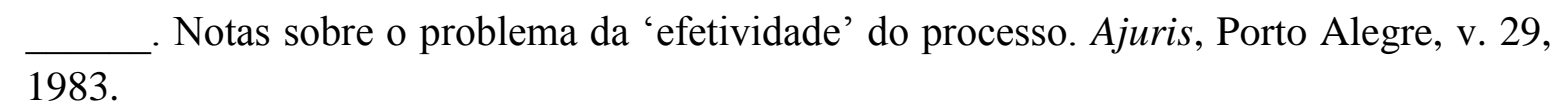

BARROS, Marco Antonio de. A busca da verdade no processo penal. 3. ed. São Paulo: Ed. Revista dos Tribunais, 2011.

BEDAQUE, Jose Roberto dos Santos. Direito e processo: influencia do direito material sobre o processo. Dados da edição utilizada 2007.

Efetividade do processo e técnica processual. 2. ed. São Paulo: Malheiros Ed., . Nulidade processual e instrumentalidade do processo. Revista do Processo, São Paulo, ano 15, n. 60, out./dez. 1990.

BELTRAN, Jordi Ferrer. Prova e verità nel diritto. Bologna: Il Mulino, 2004.

BINDER, Alberto. El incumplimiento de las formas procesales. Buenos Aires: Ad-Hoc, 2009.

Introdução ao direito processual penal. Trad. Fernando Zani. Rio de Janeiro: Lumen Juris, 2003.

BITTENCOURT, Cezar Roberto. Tratado de direito penal. 17. ed. São Paulo: Saraiva, 2012. v. 1.

BLUME, John; GARVEY, Stephen. Harmless error in Federal Habeas Corpus After Brecht v. Abrahamson. Wm. \& Mary Law Review, v. 35, n. 163, 1993.

BOCCHIOLA, Maurizio. Perdita di una"chance" e certezza del dano. Rivista Trimestrale di Diritto e Procedura Civile, Milano, ano 30, 1976.

BONAVIDES, Paulo. Ciência política. 10. ed. São Paulo: Malheiros Ed., 2003.

BORDEAUX, Raymond. Philosophie de la procédure civile: mémoire sur la réformation de la justice. Évreux: Imprimerie de Auguste Hérissey, 1857.

CALAMANDREI, Piero. Processo y democracia. Tradução Hector Fix Zamudio. Buenos Aires: Ediciones Jurídicas, 1960.

Verità e verossimiglianza nel proceso civile. Rivista di Diritto Processuale, Padova, v. 20, II série, 1965. 
CALMON DE PASSOS, Joaquim. Esboço de uma teoria das nulidades aplicadas às nulidades processuais. Rio de Janeiro: Forense, 2009.

CANOTILHO, José Joaquim Gomes. "Brancosos" e interconstitucionalidade: itinerários dos discursos sobre a historicidade constitucional. Coimbra: Almedina, 2009.

CAPEZ, Fernando. Curso de processo penal. 6. ed. São Paulo: Saraiva, 2001.

CAPONE, Arturo. L'invalidità nel processo penale. Milano: Cedam, 2012.

CARNELUTTI, Francesco. Lecciones sobre el proceso penal. Trad. Santiago Melendo. Buenos Aires: Bosch, 1950.

Sistema di diritto processuale civile. Milano: CEDAM, 1936.

Verità, dubbio, certezza. Rivista di Diritto Processuale, Padova, v. 20, 1965.

CARRARA, Francesco. Il diritto penale e la procedura penale. In:CARRARA, Francesco. Opuscoli di diritto criminale.Prato: Tip. Giachetti Figlio, 1881.v. 5.

CARVAlHO, Luis Gustavo Grandinetti Castanho de. Processo penal e Constituição. 5. ed. Rio de Janeiro: Lumen Juris, 2009.

CARVALHO. Salo de. Pena e garantias. 3. ed. Rio de Janeiro: Lumen Juris, 2008.

As reformas parciais no processo penal brasileiro. In: CARVALHO, Amilton Bueno de; CARVALHO, Salo de (Orgs.). Reformas penais em debate. Rio de Janeiro: Lumen Juris, 2005.

; LOUREIRO, Antonio Tovo. Nulidades no processo penal e Constituição: estudo de casos a partir do referencial garantista. In: PRADO, Geraldo (Org.). Processo penal e democracia. Rio de Janeiro: Lumen Juris, 2009.

CAVANI BRAIN, Renzo. Nulidad e forma en el proceso civil: perspectiva histórica de la función de la nulidad procesal en su camino hacia el modelo de la finalidad. Derecho \& Sociedad, n. 38, p. 215-236, 2012.

CHIOVENDA, Giuseppe. Instituições de direito processual civil. Campinas: Bookseller, 2002. v. 3.

CHOUKR, Fauzi Hassan. Código de Processo Penal: comentários consolidados e crítica jurisprudência. São Paulo: Saraiva, 2014.

CINTRA, Antonio Carlos de Araújo; DINAMARCO, Cândido Rangel; GRINOVER, Ada Pellegrini. Teoria geral do processo. 28. ed. São Paulo: Malheiros Ed., 2012. 
CLARIÁ OLMEDO, Jorge. Derecho procesal penal. Santa Fe: Rubinzal-Culzoni, 1998.

CONDE CORREIA, João. Contributo para análise da inexistência e das nulidades processuais penais. Coimbra: Coimbra Ed., 1999.

CONSO, Giovanni. Il concetto e le specie d'invalidatà: introduzione alla teoria dei vizi degli atti processuali penali. Milano: Giuffrè, 1972.

; GREVI, Vittorio. Compendio di procedura penale. 5. ed. Milano: Cedam, 2010.

CORDERO, Franco. Guida alla procedure penale. Torino: UTET, 1986.

Procedimiento penal. Trad. Jorge Guerrero. Temis: Santa Fé, 2000. v. 1.

Procedura penale. Milano: Giuffrè, 2000.

COUTINHO, Jacinto Nelson de Miranda. Introdução aos princípios gerais do processo penal brasileiro. Revista de Estudos Criminais, Porto Alegre, v. 1, n. 1, p. 26-51, 2001.

A lide e o conteúdo no processo penal. Curitiba: Juruá, 1989.

COUTURE, Eduardo J. Fundamentos del derecho procesal civil. 4. ed. Buenos Aires: Euros, 2002.

Fundamentos do direito processual civil. Trad. Benedicto Giaccobini. Campinas: Red Livros, 1999.

CREUS, Carlos. Invalidez de los actos procesales penales. Buenos Aires: Astrea, 1992.

DALIA, Andrea Antonio; FERRAIOLI, Marcia. Manuale di diritto processuale penale. 7. ed. Padova: Cedam, 2010.

DAMASKA, Mirjan. Evidentiary barriers do conviction and two models of criminal procedure: a comparative study. Yale Law School Legal Scholarship Repository, 1-1-1973.

The faces of justice and state authority. New Haven: Yale University Press, 1986.

DERSHOWITZ, Alan. Letters to a young lawyer. New York: Basic Books, 2001.

DEZEM, Guilherme Madeira. A flexibilização no processo penal. 2013. Tese (Doutorado)

- Faculdade de Direito da Universidade de São Paulo, São Paulo, 2013.

DIAS, Jorge Figueiredo. Direito processual penal. Coimbra: Coimbra Ed., 2004. v. 1. Direito processual penal. Coimbra: Coimbra Ed., 1974. v. 1. 
DI GIULIO, Gabriel. Nulidades procesales. Buenos Aires: Hammurabi, 2005.

DINAMARCO, Candido Rangel. Instituições de direito processual civil. 6. ed. São Paulo: Malheiros Ed., 2009. v. 1 e v. 2.

A instrumentalidade do processo. 14. ed. São Paulo: Malheiros Ed., 2009.

DI PAOLO, Gabriella. La sanatoria delle nullità nel processo penale. Milano: Cedam, 2012.

DWORKIN, Ronald. Taking rights seriously. 6. ed. London: Duckworth, 1991.

FAIRÉN GUILLÉN, Víctor. El proceso como función de satisfación jurídicas. Revista de Revista de Derecho Procesal Iberoamericana, Madrid, n. 1, 1969.

FANULI, Giuseppe Luigi. Le nullità nel processo penale. Milano: Giuffrè, 2013.

FEITOZA, Denilson. Direito processual penal: teoria, crítica e práxis. 5. ed. Rio de Janeiro: Impetus, 2008.

FELDENS, Luciano. Ministério Público, processo penal e democracia: identidade e desafios. In: PRADO, Geraldo; MALAN, Diogo (Coords.). Processo penal e democracia. Rio de Janeiro: Lumen Juris, 2009.

FERNANDES, Antonio Scarance. Processo penal constitucional. 7. ed. São Paulo: Ed. Revista dos Tribunais, 2012.

FERNANDES, Paulo Sergio Leite. Nulidades no processo penal. São Paulo: Ed. Revista dos Tribunais, 1976.

; FERNANDES, Geórgia Bajer. Nulidades no processo penal. São Paulo: Ed. Revista dos Tribunais, 1994.

FERRAJOLI, Luigi. Derecho y razón. 4. ed. Trad. Perfecto Andrés Ibañez; Alfonso Ruiz Miguel; Juan Carlos Bayón Mohino; Juan Terradillos Basoco e Rocío Cantarero Bandrés. Madrid: Trotta, 2000.

Derechos y garantias: la ley del más débil. Trad. Perfecto Andrés Ibáñeze Andrea Greppi. 3. ed. Madrid: Trotta, 1999.

FISCHER, David. Tort recovery for loss of a chance. Wake Forest Law Review, n. 605, 2001. 
FLORIAN, Eugenio. Appunti sugli atti giuridici processuali penali. Estr. da: Rivista Diritto Processuale Penale, Milano, anno 7, n. 7, p. 1916.

. Elementos de derecho procesal penal. Trad. Leonardo Prieto Castro. Madrid: Bosch, 1934.

FOUCAULT, Michel. A verdade e as formas jurídicas. Rio de Janeiro: Nau Ed., 2003.

GALLO, Marcello; CONSO, Giovanni. Instituzioni di diritto e procedura penale. Milano: Giuffrè, 1964.

GARCIA, Basileu. Instituições de direito penal. 7. ed. São Paulo: Saraiva, 2008. v. 1, t. 1.

GIACOMOLLI, Nereu. O devido processo penal. São Paulo: Atlas, 2014.

GLOECKNER, Ricardo Jacobsen. Nulidades no processo penal: introdução principiológica à teoria do ato processual irregular. Salvador: Jus Podium, 2013.

- Uma nova teoria das nulidades: processo penal e instrumentalidade constitucional. 2010. Tese (Doutorado). Faculdade de Direito da Universidade Federal do Paraná, UFPR, Curitiba, 2010. Disponível em: <http://dspace.c3sl.ufpr.br/dspace/bitstream/handle/1884/24494/GLOECKNER,\%20RICA RDO\%20JACOBSEN\%20-\%20Copia.pdf?sequence=1>.

GOLDSCHMIDT, James. Problemas jurídicos y políticos del proceso penal. Barcelona: Bosch, 1935.

. Teoría general del proceso. Trad. Leonardo Prieto Castro. Barcelona, Editorial Labor, 1936.

GOMES FILHO, Antonio Magalhães. Direito à prova no processo penal. São Paulo: Ed. Revista dos Tribunais, 1997.

A motivação das decisões penais. 2. ed. São Paulo: Ed. Revista dos Tribunais, 2013.

GOMES ORBANEJA, Emilio. Comentarios a la Ley de Enjuiciamiento Criminal. Barcelona: Bosch, 1947. t. 1.

GÖSSEL, Karl Heinz. El derecho procesal penal en el Estado de derecho. Buenos Aires: Rubinzal - Culzoni Editores, 2007.

GRAU, Eros Roberto. Por que tenho medo dos juízes?: (a interpretação/aplicação do direito e dos princípios). 6. ed. ref. do: ensaio e discurso sobre a interpretação/aplicação do direito. São Paulo: Malheiros Ed., 2013. 
GRECO, Luis. As regras por trás da exceção: reflexões sobre a tortura nos chamados “casos de bomba-relógio". Revista Brasileira de Ciências Criminais, São Paulo, v. 17, n. 78, p. 7-40, maio/jun. 2009.

GRECO FILHO, Vicente. Processo penal. 7. ed. São Paulo: Saraiva, 2009.

GRINOVER, Ada Pellegrini. O conteúdo da garantia do contraditório. In: GRINOVER. Ada Pellegrini. Novas tendências do direito processual. Rio de Janeiro: Forense Universitária, 1996.

As garantias constitucionais no processo. In: GRINOVER. Ada Pellegrini. Novas tendências do direito processual de acordo com a Constituição de 1988. São Paulo: Forense Universitária, 1990.

As garantias constitucionais do processo administrativo sancionatório. Revista do Advogado, São Paulo, ano 34, dez. 2014.

- Liberdades públicas e processo penal. 2. ed. São Paulo: Ed. Revista dos Tribunais, 1982.

O processo: III Série: estudos e pareceres de processo penal. Brasília: Gazeta Jurídica, 2013.

; FERNANDES, Antonio Scarance; GOMES FILHO, Antonio Magalhães. As nulidades no processo penal. 8. ed. São Paulo: Ed. Revista dos Tribunais, 2004.

;

dos Tribunais, 2011. . As nulidades no processo penal. 12. ed. São Paulo: Ed. Revista

GUASP DELGADO, Jaime. Concepto y método de derecho procesal. Presentación de Manuel Alonso Olea. Madrid: Civitas, 1997.

HERTEL, Daniel Roberto. Técnica processual e tutela jurisdicional: a instrumentalidade substancial das formas. Porto Alegre: Sérgio Antonio Fabris Editor, 2006.

IASEVOLI, Clelia. La nullità nel sistema processuale penale. Napoli: Cedam, 2008.

IBAÑEZ, Perfecto. Sobre a motivação dos fatos na sentença penal. In: ANDRADE, Lédio Rosa de (Org.). Valoração da prova e sentença penal. Trad. Lédio Rosa de Andrade. Rio de Janeiro: Lumen Juris, 2006.

JOURDAN, Carolyn. Criminal law and procedure - jury separation - burden of proof of prejudice to defendant. Tennessee Law Review, v. 48, 1980. 
KELSEN, Hans. Teoria pura do direito. Tradução: João Baptista Machado. 7. ed. São Paulo: Martins Fontes, 2006.

KHALED JR, Salah. Ambição de verdade no processo penal. Salvador: Podium, 2009.

KOMATSU, Roque. Da invalidade no processo civil. São Paulo: Ed. Revista dos Tribunais, 1991.

LACERDA, Galeno. Despacho saneador. Porto Alegre: La Salle, 1953.

LEITE, Luciano Marques. O conceito de "lide" no processo penal: um tema de teoria geral do processo. Justitia, São Paulo, n. 70, jul./set. 1970.

LEONE, Giovanni. Elementi di diritto e procedure penale. Napoli: Jovene, 1961.

Tratado de derecho procesal penal. Tradução Santiago Melendo. Buenos Aires: Ediciones Juridicas Europa-America, 1963. v. 1.

LIEBMAN, Enrico Tulio. Manual de derecho procesal civil. Trad. Santiago Sentis Melendo. Buenos Aires: EJEA, 1955.

LIMA, Arnaldo Siqueira. Vícios do inquérito maculam a ação penal. Boletim IBCCRIM, São Paulo, ano 7, n. 82, set. 1999.

LOPES JÚNIOR, Aury. Direito processual penal e sua conformidade constitucional. 7. ed. Rio de Janeiro: Lumen Juris, 2011. v. 1.

Direito processual penal e sua conformidade constitucional. 6. ed. Rio de Janeiro: Lumen Juris, 2011. v. 2.

Direito processual penal. 10. ed. São Paulo: Saraiva, 2013.

- Sistema de nulidades 'a la carte' precisa ser superado no processo penal. Consultor Jurídico, São Paulo, 05 set. 2014. Disponível em: <http://www.conjur.com.br/2014-set-05/limite-penal-sistema-nulidades-la-carte-superadoprocesso-penal>. Acesso em: 10 set. 2014.

LOUREIRO, Antonio Tovo. Nulidades e limitação do poder de punir: análise de discurso de acórdãos do Tribunal de Justiça do Rio Grande do Sul. Rio de Janeiro: Lumen Juris, 2009.

LOZZI, Gilberto. Lezioni di procedura penale. 7. ed. Torino: Giappicehlli Editore, 2010.

LUHMANN, Nicklas. Legitimação pelo procedimento. Trad. Maria da Conceição Côrte Real. Brasilia: Ed. da Universidade de Brasília, 1980. 
MACHADO, Rogério Schietti. Garantias processuais nos recursos criminais. 2. ed. São Paulo: Atlas, 2013.

MAIER, Julio. Derecho procesal penal. Editores del Puerto: Buenos Aires, 2004.

Función normativa de la nulidad. Buenos Aires: De Palma, 1980.

MALHEIROS FILHO, Arnaldo. Direito penal econômico e crimes de mero capricho. In: VILARDI, Celso; PEREIRA, Flavia Rahal Bresser; DIAS NETO, Theodomiro (Coords.). Direito penal econômico. São Paulo: Saraiva, 2009.

MANZINI, Vincenzo. Tratado de derecho procesal penal. Tradução Santiago Sentís Melendo y Marino Ayerra Redín. Buenos Aires: El Foro, 1996. t. 1.

Trattato di diritto processuale penale italiano. 6. ed. Torino: UTET, 1968. v. 3.

MARCUS, Paul; WILSON, Melanie. Criminal procedure. 18. ed. Chicago: ThomsonWest, 2011.

MARQUES, José Frederico. Da unidade do processo - aplicação de conceitos do processo civil no campo do processo penal. In: Estudos de direito processual penal. 2. ed. Campinas: Millenium, 2001.

Elementos de direito processual penal. Atualizadores: Eduardo Reale Ferrari e Guilherme Madeira Rezem. 3. ed. Campinas: Millenium, 2009. v. 2.

MARTINEZ, Oscar J. Los vicios del consentimiento en le realización del acto procesal. In: MORELLO, Augusto Mario (Coord.). Estudios de nulidades procesales. Buenos Aires: Hammurabi, 1980.

MARTINS-COSTA, Judith. Prefácio. In: SILVA, Rafael Pettefi da. Responsabilidade civil pela perda de uma chance. 3. ed. São Paulo: Atlas, 2013.

MEDINA ALCOZ, Luis. La teoria de la perdida de oportunidad. Navarra: Thomson Civitas, 2007.

MEIRELES, Cecília. Antologia poética. São Paulo: Ed. do Autor. 1965.

MENDES JÚNIOR, João. O processo criminal brazileiro. Rio de Janeiro: Laemmert \& Cia, 1901. v. 1. João Mendes de Almeida Júnior. OK?

MICHELI, Gian Antonio; TARUFFO, Michele. A prova. Revista de Processo, São Paulo, n. 16, out./dez. 1979. 
MIRANDA ESTRAMPES, Manuel. La minima actividad probatoria en el proceso penal. Barcelona: José Maria Bosch, 1997.

MITIDIERO, Daniel. O problema da invalidade dos atos processuais no direito processual civil brasileiro contemporâneo. Disponível em: <http://www.abdpc.org.br/abdpc/artigos>. Acesso em: 07 jun. 2013.

MONIZ DE ARAGÃO, Egas. Comentários ao Código de Processo Civil. Rio de Janeiro: Forense, 1974. v. 2.

- Nulidade, invalidade, “jardinagem”. In: TESHEINER, José Maria (Coord.). Instrumentos de coerção e outros temas de direito processual civil: estudos em homenagem aos 25 anos de docência do Professor Dr. Araken de Assis. Rio de Janeiro: Forense, 2007.

MONNERAT, Carlos Fonseca. Inversão do ônus da prova no processo penal brasileiro. São Paulo: Communicar, 2006.

MORAES, Alexandre de. Direito constitucional. 23. ed. São Paulo: Atlas, 2008.

MORAES, Mauricio Zanoide de. Presunção de inocência no processo penal brasileiro: análise de uma estrutura normativa para a elaboração legislativa e para a decisão judicial. Rio de Janeiro: Lumen Juris, 2010.

MOSSIN, Heráclito Antonio. Nulidades no direito processual penal. São Paulo: Atlas, 1998.

MUÑOZ CONDE, Francisco. La busqueda de la verdade en el proceso penal. 3. ed. Buenos Aires: Hamurabi, 2007.

NASSIF, Aramis; NASSIF, Samir. Considerações sobre nulidades no processo penal. 2. ed. Porto Alegre: Ed. Livraria do Advogado, 2012.

NORONHA, Edgard Magalhães. Curso de direito processual penal. 5. ed. São Paulo: Saraiva, 1972.

NUCCI, Guilherme de Souza. Código de Processo Penal comentado. 6. ed. São Paulo: Ed. Revista dos Tribunais, 2007.

Código de Processo Penal comentado. 8. ed. São Paulo: Ed. Revista dos Tribunais, 2008.

NUVOLONE, Pietro. Le prove vietate nel processo penale nei paesi di diritto latino. Rivista di Diritto Processuale, Padova, v. 21, II serie, 1966. 
OLIVEIRA, Carlos Alberto Álvaro de. Do formalismo no processo civil. São Paulo: Saraiva, 2009.

OLIVEIRA FILHO, João de. Código do Processo Penal de Minas Gerais. São Paulo: Casa Duprat, 1927.

ORBANEJA, Emilio; QUEMADA, Vicente. Derecho procesal penal. 7. ed. Madrid: Ediciones Madrid, 1972.

ORDEIG, Gimbernat. Problemas actuales de derecho penal y procesal. Salamanca: Bosch, 1971.

PACELLI, Eugenio. Curso de processo penal. 15. ed. Rio de Janeiro: Lumen Juris, 2011.

Processo e hermenêutica na tutela penal dos direitos fundamentais. 2. ed. Rio de Janeiro: Lumen Juris, 2009.

PANNAIN, Remo. Le sanzioni degli atti processuali penale. Milano: Giuffrè, 1957.

PASCHOAL, Jorge Coutinho. O prejuízo na teoria das nulidades processuais penais e sua análise jurisprudencial nos Tribunais Superiores. 2014. Dissertação (Mestrado) Faculdade de Direito da Universidade de São Paulo, São Paulo, 2014.

PASSO CABRAL, Antonio do. Nulidades no processo moderno: contraditório, proteção da confiança e validade prima facie dos atos processuais. Rio de Janeiro: Forense, 2010.

PATTON, William Wesley. To err is human, to forgive, often unjust. US Davis Journal of Juvenile Law \& Policy, v. 13, 2009.

PAULA, Leonardo Costa de. As nulidades no processo penal. Curitiba: Juruá, 2013.

PIERRE-MAURICE, Sylvie. Le Code de Procédure Civile et les maximes. Revue Scientia Juris, n. 2, 2013.

PIÑERO BERTOT, Maria Inês. La nulidad como "garantia das garantias”. In: DIAZ, Carlos Alberto Chiara (Coord.). Las nulidades y los medios de impugnación en el proceso penal. Buenos Aires: Ed. Delta, 2004.

PISAPIA, Gian Domenico. Compendio di procedura penale. 5. ed. Padova: Cedam, 1988.

PLETSCH, Natalie Ribeiro. A atuação dos sujeitos processuais na formação da prova: o magistrado e o alcance da verdade no processo penal. Revista de Estudos Criminais, ano 4, n. $18,2005$. 
PODETTI, Ramiro. Teoria y tecnica del proceso civil y trilogia estructural de la ciencia del proceso civil. Buenos Aires: Ediar, 1963.

PONTES DE MIRANDA, Francisco Cavalcanti. Tratado de direito privado. 4. ed. São Paulo: Ed. Revista dos Tribunais, 1974. t. 4.

PORTO, Pedro Rui da Fontoura. Considerações sobre a impossibilidade de uma teoria geral do processo penal e civil a partir da investigação acerca do conteúdo do processo penal. Revista do Ministério Público, Porto Alegre, n. 49, 2003.

REALE, Miguel. Filosofia do direito. 18. ed. São Paulo: Saraiva, 1998.

ROSA, Alexandre de Morais. Guia compacto do processo penal conforme a teoria dos jogos. 2. ed. Rio de Janeiro: Lumen Juris, 2014.

ROSA, Inocencio Borges da. Comentários ao Código de Processo Penal. 3. ed. atualizada por Angelito Aiquel. São Paulo: Ed. Revista dos Tribunais, 1982.

. Nulidades no processo. Porto Alegre: Livraria do Globo, 1935.

ROXIN, Claus. Derecho penal. Trad. Manuel Luzon Pena, Miguel Diaz y Gargia Conlledo e Javier de Vicente Remesal. 2. ed. Madrid: Civitas, 1997. t. 1.

SAAD, Marta. $O$ direito de defesa no inquérito policial. São Paulo: Ed. Revista dos Tribunais, 2004.

SANGUINÉ, Odone. A inconstitucionalidade do clamor público como fundamento da prisão preventiva. Boletim IBCCRIM, São Paulo, out. 2001.

SANTOS, Leandro Galluzzi dos. In: MOURA, Thereza Rocha de Assis (Coord.). As reformas no processo penal. São Paulo: Ed. Revista dos Tribunais, 2008.

SATTA, Salvatore. Diritto processual civile. Padova: Cedam, 1948.

SAVI, Sérgio. Responsabilidade civil por perda de uma chance. 3. ed. São Paulo: Atlas, 2012.

SCHMIDT, Eberhard. Derecho procesal penal. Trad. Jose Manuel Nuñez. Editorial Bibliográfica Argentina: Buenos Aires, 1957.

Los fundamentos teóricos y constitucionales del derecho procesal penal. Tradução José Nuñez. Buenos Aires: Lerner, 2006. 
SILVA, Germano Marques da. Curso de processo penal. Lisboa: Editorial Verbo, 1994. t. 1.

SILVA, Luís Virgílio Afonso da. Direitos fundamentais: conteúdo essencial, restrições e eficácia. São Paulo: Malheiros Ed., 2009.

SILVA, Rafael Pettefi da. Responsabilidade civil pela perda de uma chance. 3. ed. São Paulo: Atlas, 2013.

VIDAL, Hélvio Simões. Curso avançado de processo penal. Belo Horizonte: Arraes, 2011.

SIQUEIRA, Galdino. Curso de processo criminal. 2. ed. Rio de Janeiro: Livraria e Officinas Magalhães, 1917.

SKLANSKY, David Alan; YEAZELL, Stephen C. Comparative law without leaving home: what civil procedure can teach criminal procedure, and vice versa. The Georgetown Law Journal, v. 94, 2006.

SOUZA, José Barcelos de. Direito processual civil e penal. Rio de Janeiro: Forense, 1995.

STRECK, Lenio. O que é isto: decido conforme minha consciência? 4. ed. Porto Alegre: Livraria do Advogado, 2012.

Um sintoma do atraso de nosso direito: acreditar que basta estar na lei. Consultor Jurídico, São Paulo, 17 jul. 2014. Disponível em: <http://www.conjur.com.br/2014-jul17/senso-incomum-sintoma-nosso-atraso-nao-basta-estar-lei>. Acesso em: 19 jul. 2014.

Verdade e consenso. 4.ed. São Paulo: Saraiva, 2012.

SUANNES, Adauto. Os fundamentos éticos do devido processo penal. 2. ed. São Paulo: Ed. Revista dos Tribunais, 2004.

TARUFFO, Michele. La semplice verità. Bari: Laterza, 2009.

. Il significato constituzionale dell'obbligo di motivazione. In: GRINOVER, Ada Pellegrini; DINAMARCO, Candido Rangel; WATANABE, Kazuo. Participação $e$ processo. São Paulo: Ed. Revista dos Tribunais, 1988.

TONINI, Paolo. Lineamenti di diritto processuale penale. 8. ed. Milano: Giuffrè, 2010. . Manuale di procedura penale. 11. ed. Milano: Giuffrè, 2010. 
TORNAGHI, Hélio. Compêndio de processo penal. Rio de Janeiro: José Konfino, 1967. t. 2. . Curso de processo penal. 1. ed. São Paulo: Saraiva, 1980. v. 2. . Instituições de processo penal. 2. ed. São Paulo. Saraiva: 1977.v. 2. A relação processual penal. 2. ed. São Paulo: Saraiva, 1987.

TOURINHO FILHO, Fernando da Costa. Processo penal. 31. ed. São Paulo: Saraiva, 2009. v. 1.

_. Processo penal. São Paulo: Saraiva, 2009. v. 3.

Processo penal. 34. ed. São Paulo: Saraiva, 2012. v. 2 e v. 3.

TUCCI, Rogerio Lauria. Considerações acerca da inadmissibilidade de uma teoria geral do processo. In: PIERANGELI, José Henrique (Coord.). Direito criminal. Belo Horizonte: Del Rey, 2001. v. 3.

Direitos e garantias individuais no processo penal brasileiro. 3. ed. São Paulo: Ed. Revista dos Tribunais, 2009.

VAZ, Denise Provasi. Estudo sobre a verdade no processo penal. Revista Brasileira de Ciências Criminais, São Paulo, n. 83, 2010.

VENOSA, Silvio de Salvo. Direito civil. 12. ed. São Paulo: Atlas, 2012. v. 1.

VIEIRA, Renato Stanziola. Paridade de armas no processo penal. Brasília: Gazeta Jurídica, 2014.

WAMBIER, Teresa Arruda Alvim. Nulidades do processo e da sentença. 6. ed. São Paulo: Ed. Revista dos Tribunais, 2007.

WICHT, James Edward. There is no such thing as a harmless constitutional error: returning to a rule of automatic reversal. BYU Journal of Public Law, Indiana, v. 12, n. 73, 1997.

ZILLI, Marcos Alexandre Coelho. O pomar e as pragas. Boletim do IBCCrim, São Paulo, v. 16, n. 188, p. 2-3, jul. 2008. 